\title{
Archaeological Investigations at Four San Antonio Missions: Mission Trails Underground Conversion Project
}

Cynthia L. Tennis

Center for Archaeological Research

I. Waynne Cox

Center for Archaeological Research

Jeffery J. Durst

Center for Archaeological Research

Donna D. Edmondson

Center for Archaeological Research

Barbara A. Meissner

Center for Archaeological Research

See next page for additional authors

Follow this and additional works at: https://scholarworks.sfasu.edu/ita

Part of the American Material Culture Commons, Archaeological Anthropology Commons, Environmental Studies Commons, Other American Studies Commons, Other Arts and Humanities Commons, Other History of Art, Architecture, and Archaeology Commons, and the United States History Commons

Tell us how this article helped you.

This Article is brought to you for free and open access by the Center for Regional Heritage Research at SFA ScholarWorks. It has been accepted for inclusion in Index of Texas Archaeology: Open Access Gray Literature from the Lone Star State by an authorized editor of SFA ScholarWorks. For more information, please contact cdsscholarworks@sfasu.edu. 


\title{
Archaeological Investigations at Four San Antonio Missions: Mission Trails Underground Conversion Project
}

\author{
Authors \\ Cynthia L. Tennis, I. Waynne Cox, Jeffery J. Durst, Donna D. Edmondson, Barbara A. Meissner, and Steve \\ A. Tomka \\ Creative Commons License \\ (c) (1) ()
}

This work is licensed under a Creative Commons Attribution-NonCommercial 4.0 International License 
Archaeological Investigations at Four San Antonio Missions:

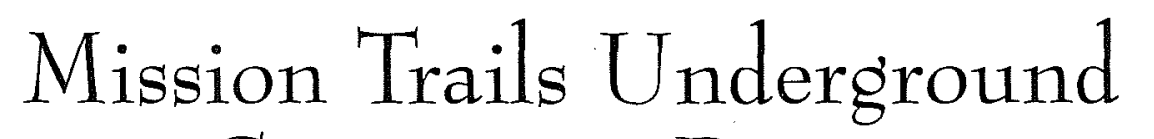

Conversion Project

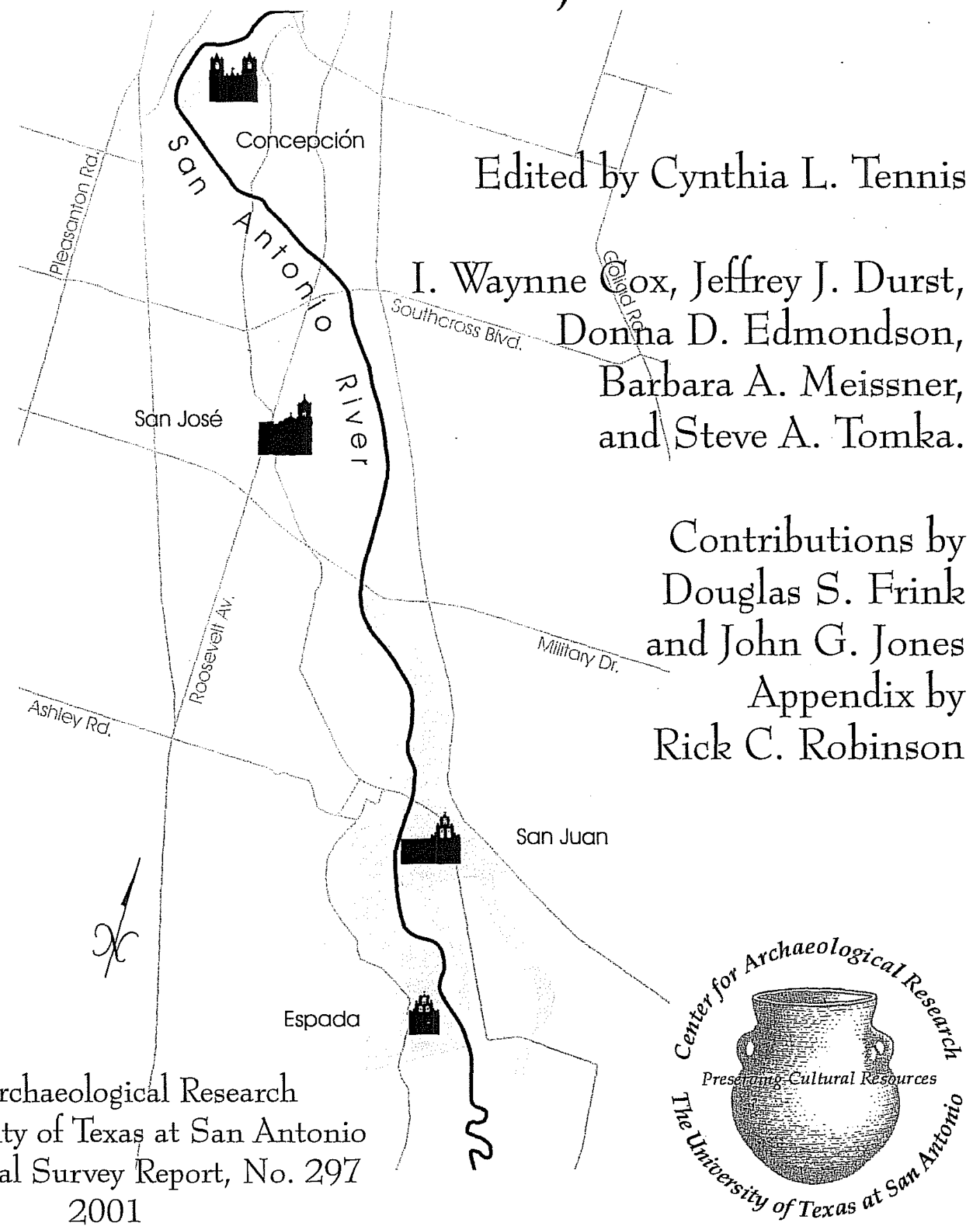

Center for Archaeological Research The University of Texas at San Antonio Archaeological Survey Report, No. 297 2001

Contributions by Douglas S. Frink Appendix by Rick C. Robinson 



\title{
Archaeological Investigations at Four San Antonio Missions: \\ Mission Trails Underground \\ Conversion Project
}

Edited by Cynthia L. Tennis

I. Waynne Cox, Jeffrey J. Durst, Donna D. Edmondson, Barbara A. Meissner, and Steve A. Tomka.

\author{
Contributions by \\ Douglas S. Frink and John G. Jones \\ Appendix by \\ Rick C. Robinson
}

\section{Robert J. Hard and Cynthia L. Tennis Principal Investigators}

Texas Antiquities Permit No. 2020

(C)opyright 2001

Center for Archaeological Research The University of Texas at San Antonio Archaeological Survey Report, No. 297 
The following information is provided in accordance with the General Rules of Practice and Procedure, Chapter 41.11 (Investigative Reports), Texas Antiquities Committee:

1. Type of investigation: Shovel testing, excavation and monitoring

2. Project name: Mission Trails - CPS Underground Conversion

3. County: Bexar

4. Principal investigator: Robert J. Hard and Cynthia L. Tennis

5. Name and location of sponsoring agency: City of San Antonio, City Public Service, 146 Navarro Street, San Antonio, Texas 78283

6. Texas Antiquities Permit No.: 2020

7. Published by the Center for Archaeological Research, The University of Texas at San Antonio, 6900 N. Loop 1604 W., San Antonio, Texas 78249-0658, 2001

A list of publications offered by the Center for Archaeological Research is available. Call (210) 458-4378; write to the Center for Archaeological Research, The University of Texas at San Antonio, 6900 N. Loop 1604 W., San Antonio, Texas 78249-0658; e-mail to car@lonestar.utsa.edu; or visit CAR's Web site at http://car.utsa.edu. 


\begin{abstract}
This report contains the results of archaeological work performed by the Center for Archaeological Research (CAR) at The University of Texas San Antonio (UTSA) for City Public Service (CPS). The archaeological investigation and monitoring for the Mission Trails Underground Conversion Project was carried out under Texas Historical Commission (THC) Permit Number: 2020, and the work was conducted at each of the four historical San Antonio missions which make up San Antonio Missions National Historical Park.

The Mission Trails Underground Conversion Project was created to enhance and upgrade electrical and utility connections by replacing aboveground connections with underground connections at each of the four missions.
\end{abstract}

\title{
Mission San Juan (41BX5)
}

Tn October of 1998, personnel from CAR began archaeological investigations at Mission San Juan Capistrano In advance of the proposed installation of underground utility lines for the Mission Trails Underground Conversion Project. The purpose of the investigation was to test for intact, buried cultural features in advance of trenching activities involved in the relocation of utility lines and connections. CAR archaeologists developed a plan regarding the area to be impacted which included ten $1 \times 1-\mathrm{m}$ excavations units and a series of twelve shovel tests along the proposed path of the utility trench. Excavation units uncovered evidence of existing buildings, wall foundations and Colonial-period flooring episodes, revealing new data west of the known structures and not previously accounted for. Further excavations are warranted to determine the nature of features such as a Colonial-period wall revealed near one of the excavation units. This material discovered by the archaeological investigations resulted in the altering of the projected utility trench alignment to avoid disturbing deposits. Further archaeological investigations are recommended for the newly revealed features.

\section{Mission San José (41BX3)}

Tn January of 1999, personnel from CAR began archaeological investigations at Mission San José y San Miguel de Aguayo in advance of the proposed installation of underground utility lines for the Mission Trails Underground Conversion Project. The purpose of the investigation was to test for intact, buried cultural features in advance of trenching activities involved in the relocation of utility lines and connections. CAR archaeologists conducted a series of shovel tests along the center-lines of the proposed utility trenches to identify areas of possible impact to intact Spanish Colonial cultural materials. In addition to shovel testing, monitoring of the trenching was conducted in areas where the possibility of impacting cultural material was high. An early-twentieth century trash midden was encountered during monitoring of the trench where it paralleled the Service Drive in the northwest corner of the Mission compound. This material did not warrant altering the course of the trench, and no further archaeological work is recommended at this time. 


\section{Mission Concepción (41BX12)}

Tn January of 1999, personnel from CAR began archaeological investigations at Mission Nuestra Señora de la 1 Purísima Concepción as part of the Mission Trails Underground Conversion Project. A construction crew, while excavating a manhole designed to provide access to underground electrical utilities, had unearthed a large number of animal bones. After concluding a large feature had been unexpectedly impacted, CAR conducted test excavations to ascertain the nature of this feature. It was determined to be a section of an acequia which had been refilled during the Colonial period with construction debris and trash, including a large number of animal bones. Test units and the original manhole excavations allowed for a profile of the acequia to be constructed. This information combined with previous archaeological work and historical research, allowed a tentative proposal on the sequence of acequia construction and re-routing for the Concepción mission. Monitoring of other underground work conducted in the area resulted in the discovery of a location of a Colonial-period wall, southeast of the Visitors' Center, which may be a portion of the original south wall of the mission. It is recommended that if any further work is required, consideration should be given to testing and/or monitoring to reduce the risk of negative impact to historic remains.

\section{Mission Espada (41BX4)}

Tn July of 1999, personnel from CAR began archaeological investigations at Mission San Francisco de la Espada in advance of the proposed installation of underground utility lines for the Mission Trails Underground Conversion Project. From initial discussions, it was noted that the proximity of the proposed route of the underground utility trench could have an impact on the old compound walls of the mission and the path was altered to avoid any possible impact. A series of thirteen shovel tests were conducted in advance along the altered path of the proposed utility trench as it progressed from the southwest corner of the mission compound across the dry irrigation ditch or acequia to the northwest. Monitoring of the trenching activities followed with no significant deposits being exposed. No further work is recommended within the project area, but if future construction is to occur in the area between the utility trench and the Church at Mission Espada, monitoring should then be considered. 


\section{Contents}

\section{Mission San Juan}

Abstract

Figures

Tables

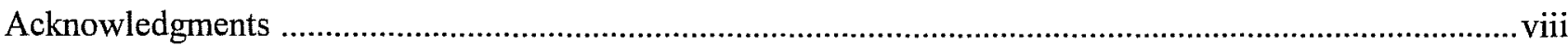

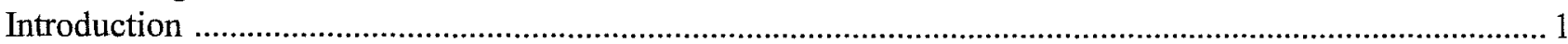

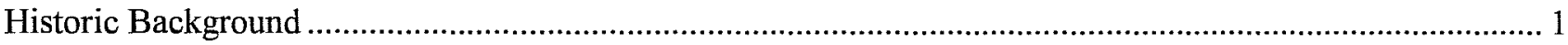

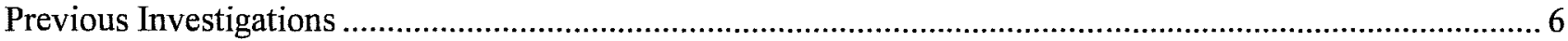

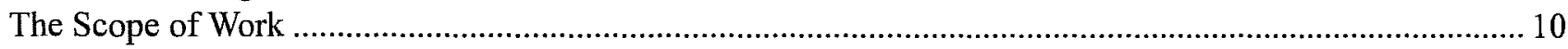

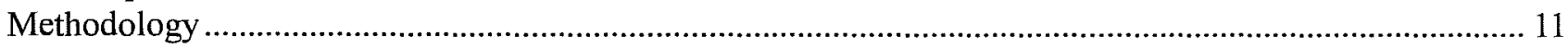

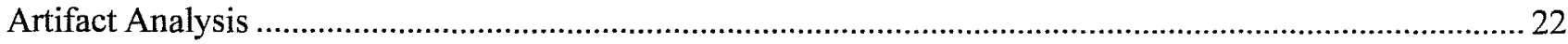

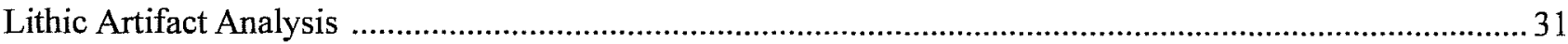

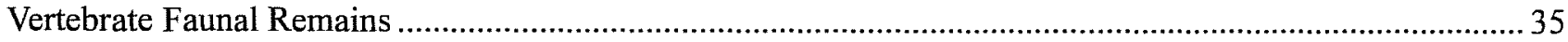

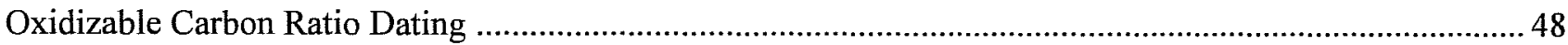

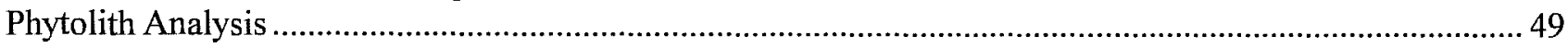

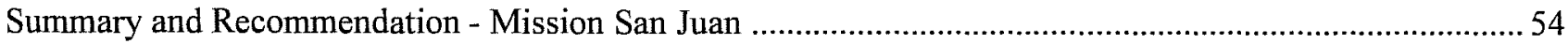

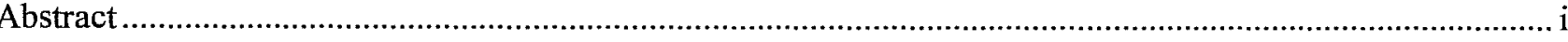

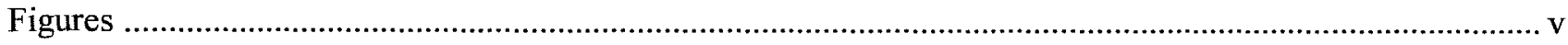

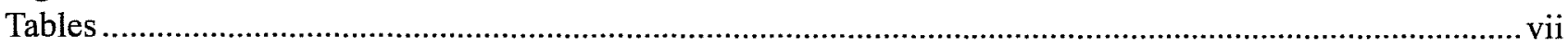

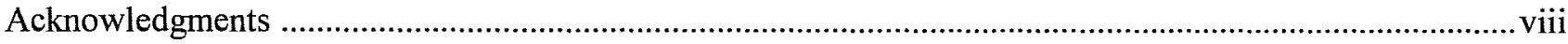

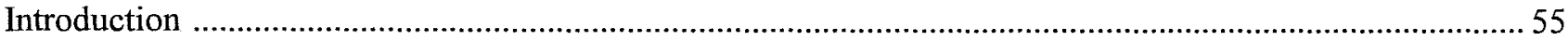

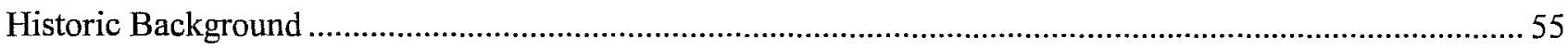

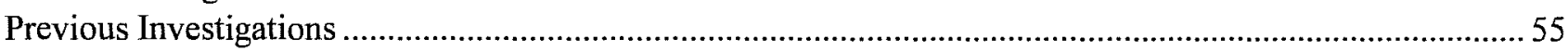

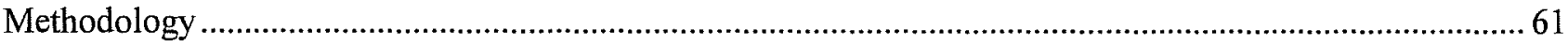

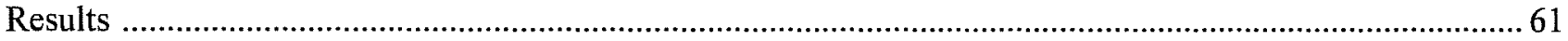

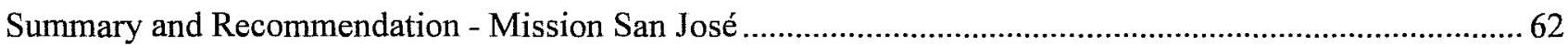

Abstract

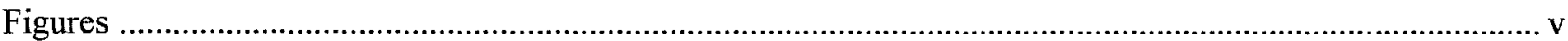

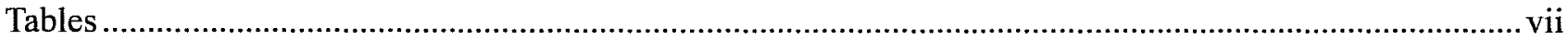

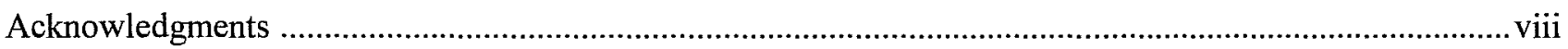

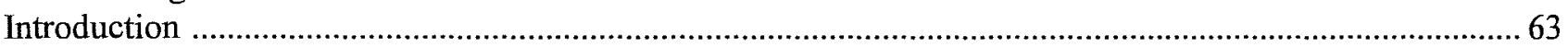

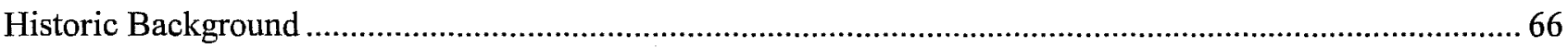

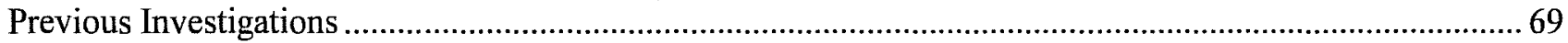

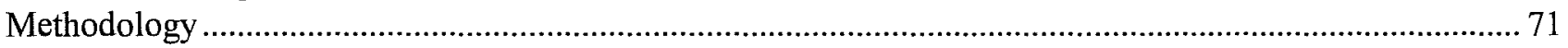

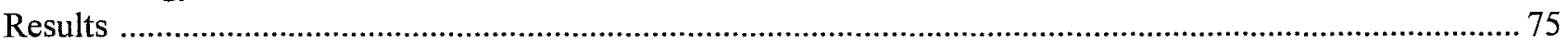

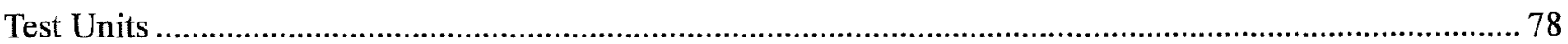

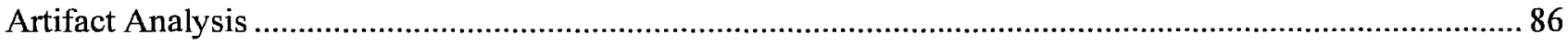

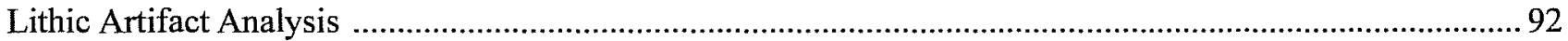

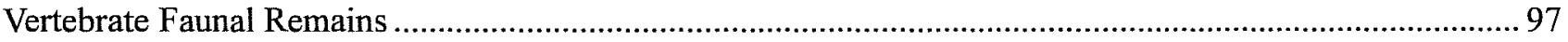

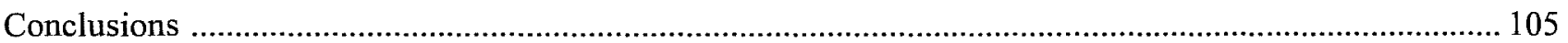

Summary and Recommendation - Mission Concepción .............................................................. 105

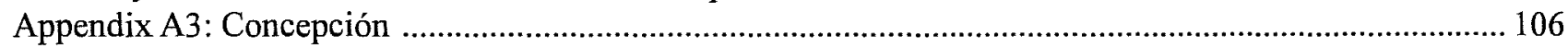




\section{Mission Espada}

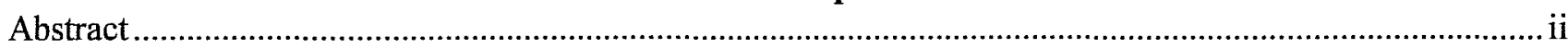

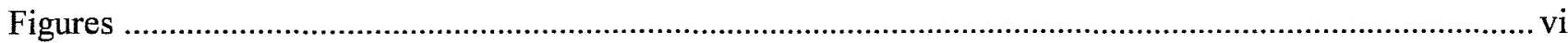

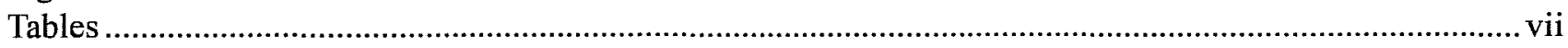

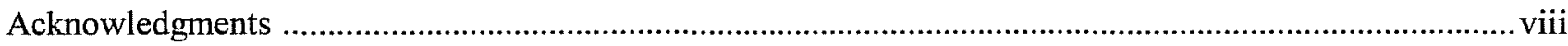

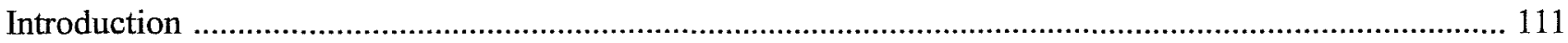

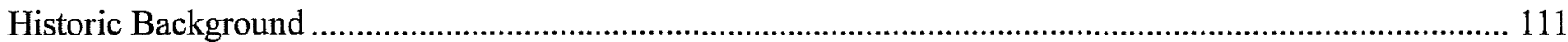

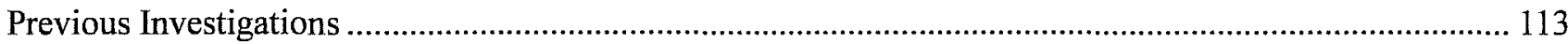

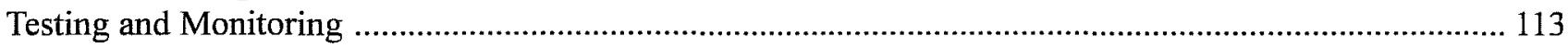

Summary and Recommendation - Mission Espada …………................................................................. 116

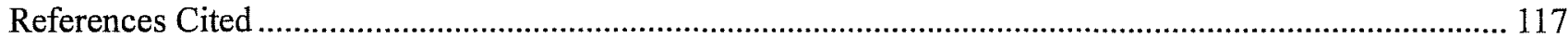




\section{Figures}

\section{Mission San Juan}

Figure 1-1. The five San Antonio Missions with Mission San Juan Capistrano highlighted. ..........................2

Figure 1-2. Updated rendering of 1890 William Corner map of the ruins of Mission San Juan ...................... 4

Figure 1-3. Early postcard image of the ruins of the Chapel at Mission San Juan...................................... 5

Figure 1-4. Rendering of ca. 1933 Harvey P. Smith (WPA) investigations. ................................................ 7

Figure 1-5. Map indicating early investigations conducted at San Juan. ................................................. 9

Figure 1-6. Map indicating current project excavations. .............................................................. 12

Figure 1-7. Composite map from geophysical survey. ............................................................... 13

Figure 1-8. Representative diagram of wall foundation stones (Unit 3). ........................................... 16

Figure 1-9. Profile map of Units located west of the Chapel. ............................................................ 16

Figure 1-9a. San Juan, West profile of Unit 9.. .............................................................................. 17

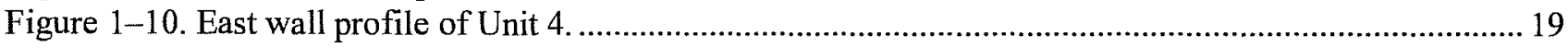

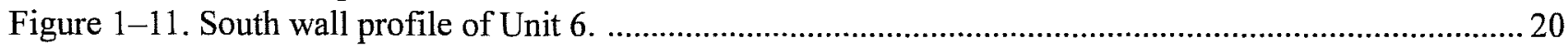

Figure 1-12. Ceramics: a) Goliad ware; b) Sandy Paste Lead-glaze ware; c) Majolica............................... 22

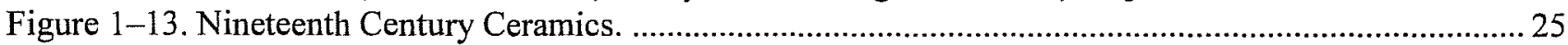

Figure 1-14. Intact, slim clear glass bottle recovered from Unit 7, Level 6.........................................27

Figure 1-15. Lithic artifacts recovered from Mission San Juan. ........................................................... 33

Figure 1-16. Debitage cortex categories from Mission San Juan. ......................................................... 33

Figure 1-17. Debitage Size Class categories in $10 \mathrm{~mm}$ increments from Mission San Juan......................... 34

Figure 1-18. Platform Faceting categories among Platform-bearing debitage, Mission San Juan. ................. 34

Figure 1-19. Lithic Reduction types among Classifiable debitage, Mission San Juan. ............................... 34

Figure 1-20. Three views of a grossly, deformed phalange of a deer. ................................................... 41

Figure 1-21. San Juan, Count of bovid elements in high, moderate, and low grease utility categories. .......... 43

Figure 1-22. San Juan, Phytolith percentage diagram. .................................................................. 52

\section{Mission San José}

Figure 2-1. The five San Antonio Missions with Mission San José y San Miguel de Aguayo highlighted. .... 56

Figure 2-2. Map of Mission San José compound indicating Shovel Tests (1-12) and Utility trench............. 57

Figure 2-3. Aerial photograph of the Mission San José compound ca. 1930s..........................................58

\section{Mission Concepción}

Figure 3-1. Project area (looking northeast): manhole pit shown in lower right

Figure 3-2. Five San Antonio Missions with Mission Nuestra Señora de la Purísima Concepción highlighted. ... 64

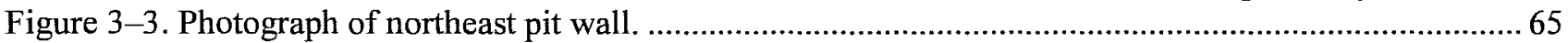

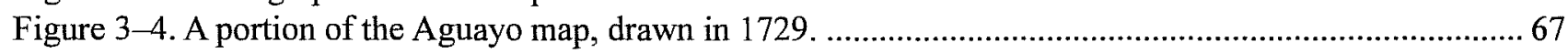

Figure 3-5. Previous excavations at Mission Concepción. ............................................................. 70

Figure 3-6. Map of area showing line of a possible lateral acequia. ...................................................... 72

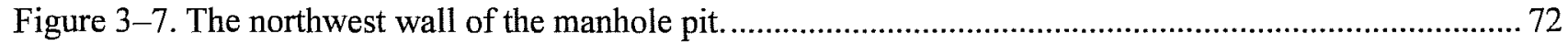

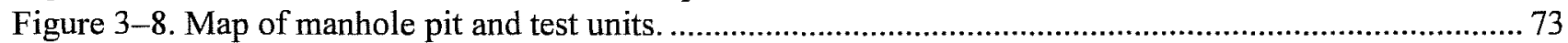

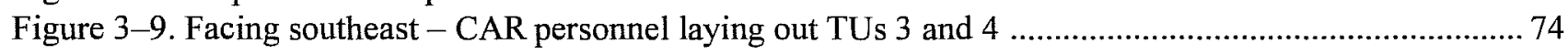

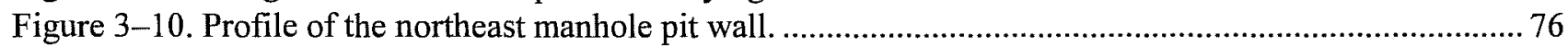

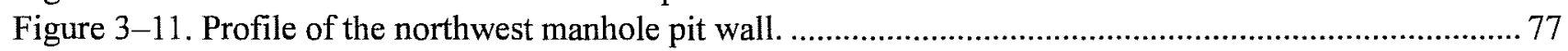

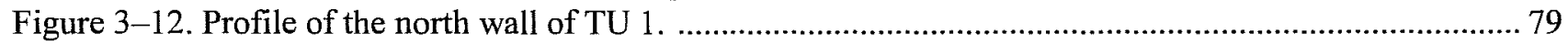

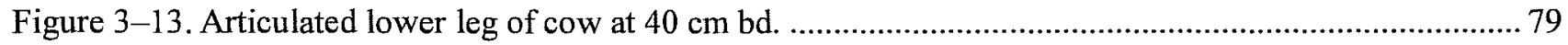

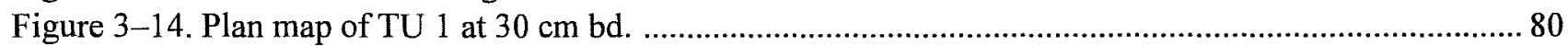

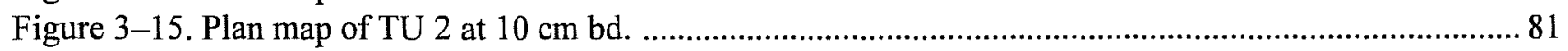

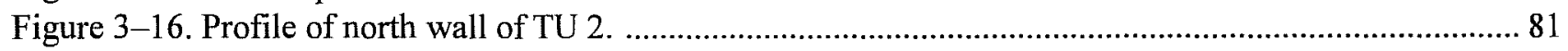


Figure $3-17$. TU 3 at $50 \mathrm{~cm}$ bd, large limestone rock in northeastern corner. ....................................... 82

Figure 3-18. Profile of north wall of TU 3 (right) and TU 4 (left) .................................................... 83

Figure 3-19. TU 4, indicating evidence of pipe trench in western $1 / 3$ of Test Unit 4............................. 84

Figure 3-20. Composite profile of the north wall of the acequia....................................................... 85

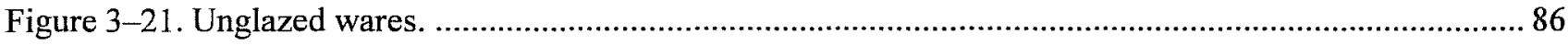

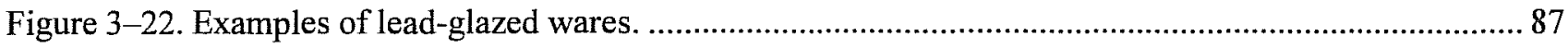

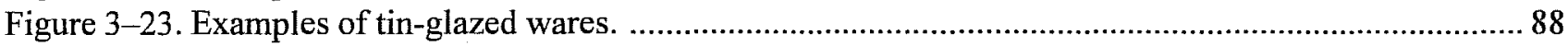

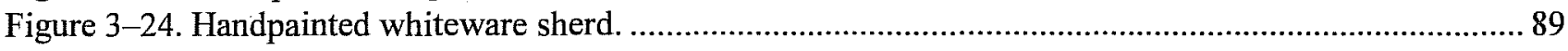

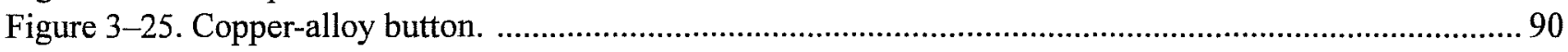

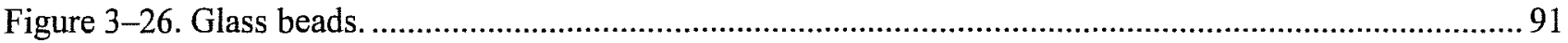

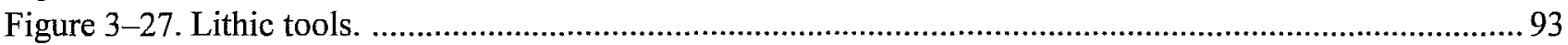

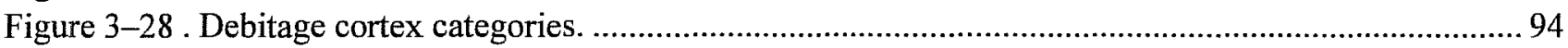

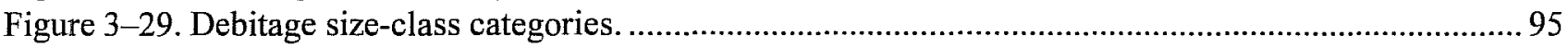

Figure 3-30. Platform faceting categories among platform-bearing debitage. ....................................... 95

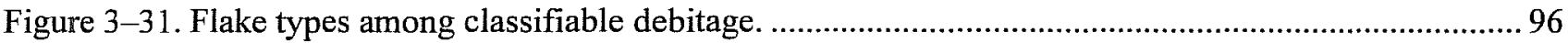

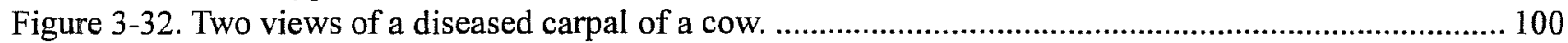

Figure 3-33. Map of Mission Concepción locations where acequias have been encountered. .................... 103

Figure 3-34. Suggested routes and dates of acequias in the vicinity of Concepción................................. 104

Figure A3-1. Location of Colonial wall northeast of the manhole pit. .................................................... 106

Figure A3-2. Facing northeast, location of the trench east of the manhole. .......................................... 107

Figure A3-3. North end of trench showing remains of wall in the long (east) profile. .............................. 108

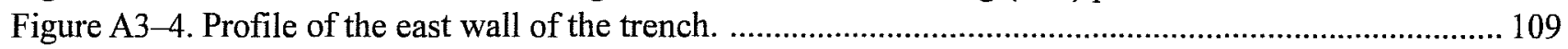

Figure A3-5. North wall of trench profile, showing possible palisade trench. ....................................... 109

Figure A3-6. Profile of the north wall of the trench. .................................................................... 110

\section{Mission Espada}

Figure 4-1. The five San Antonio Missions with Mission San Francisco de la Espada highlighted............. 112

Figure 4-2. Route of electrical utility trench and shovel tests at Mission Espada..................................... 114

Figure 4-3. Section of Mission Espada's trenching area with advance shovel testing in progress. .............. 114 


\section{Tables}

\section{Mission San Juan}

Table 1-1. San Juan, Ceramics by categories .22

Table 1-2. A comparison of Non-Native-Made Ceramic Types.

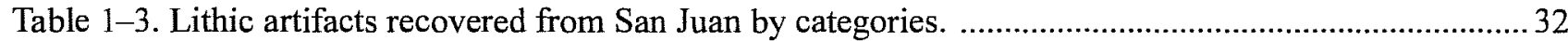

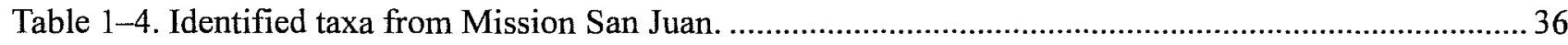

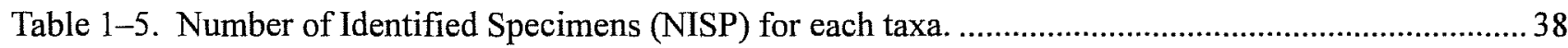

Table 1-6. Percent of Total NISP Bone Weight for selected taxa. ........................................................... 39

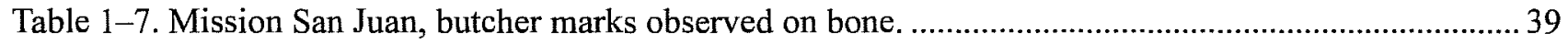

Table 1-8. Mission San Juan, stages of heat alteration exhibited by bone in Test Units. .............................. 40

Table 1-9. Mission San Juan, Total burned bone and heavily burned bone by Unit. ................................... 40

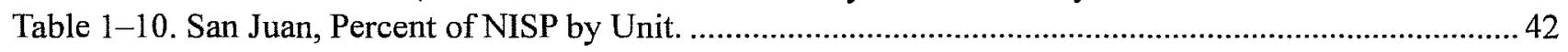

Table 1-11. San Juan, Percent of minimally identified bone by Unit. .................................................... 42

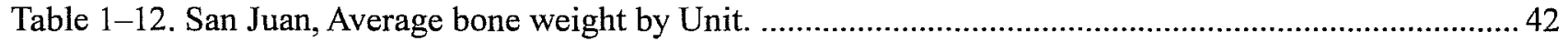

Table 1-13. San Juan, Percent of NISP by Level in Unit 9................................................................... 44

Table 1-14. San Juan, Percent of NISP by Level (below Level 4) in Unit 9. .......................................... 45

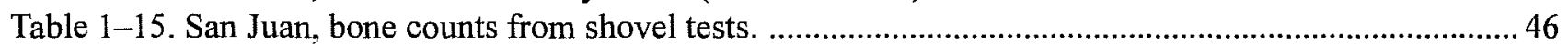

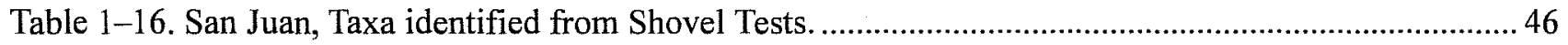

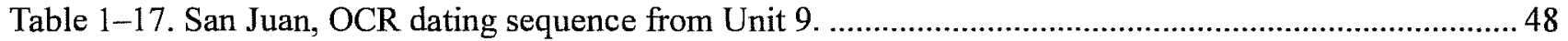

Table 1-18. San Juan, Phytoliths identified in the eight sediment samples. ..............................................5 51

\section{Mission San José}

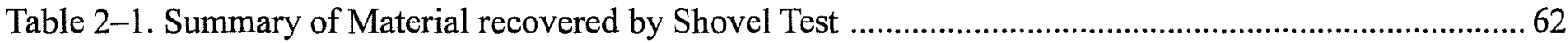

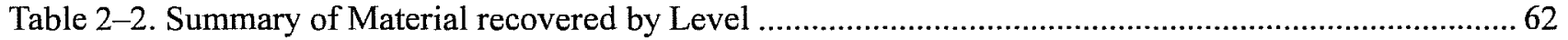

\section{Mission Concepción}

Table 3-1. Unit datum locations and depths below project datum ........................................................ 74

Table 3-2. Artifacts recovered from TU 1, by level ....................................................................... 78

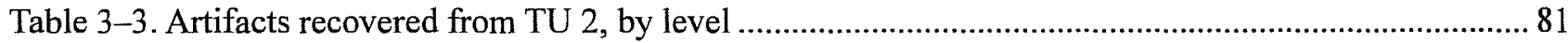

Table 3-4. Artifacts recovered from TU 3, by level ..................................................................... 82

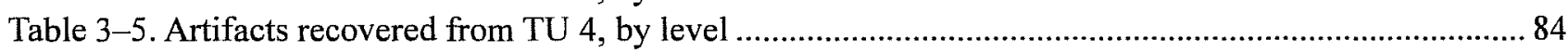

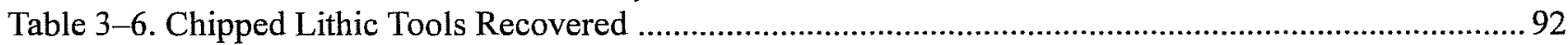

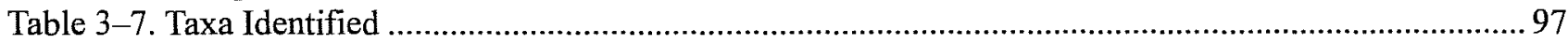

Table 3-8. Count, Weight, and Average Bone Weight for each Test Unit Level .........................................98

Table 3-9. Bone Identified to the Genus Taxonomic Level .................................................................99

Table 3-10. Butcher Marks Observed on Bone ...................................................................................99

Table 3-11. Percent of Total NISP Bone Weight for Selected Taxa at San Antonio Missions ..................... 101

Table 3-12. Percent of Total NISP Bone Weight for Selected Taxa at Two Goliad Missions ..................... 101

Mission Espada

Table 4-1. Mission Espada Shovel Test results by level 


\section{Acknowledgments}

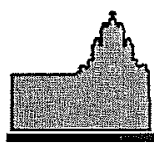

Mission

San Juan

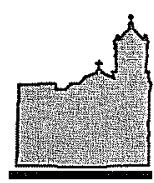

Mission

San José
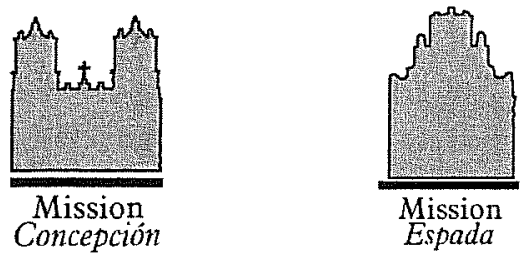

W Would like to take this opportunity to express our gratitude and appreciation to the personnel of CPS for their co-operation on the Mission Trails Underground Conversion Project. The engineer in charge was Marco Garcia and the field inspector was Larry Bockman. Dr. Robert J. Hard, director of CAR provided the guidance necessary for each of these investigations. Thanks are also extended to all CAR personnel who worked on the various stages of this project and to technical editor, Maryanne King for preparing this final report. 


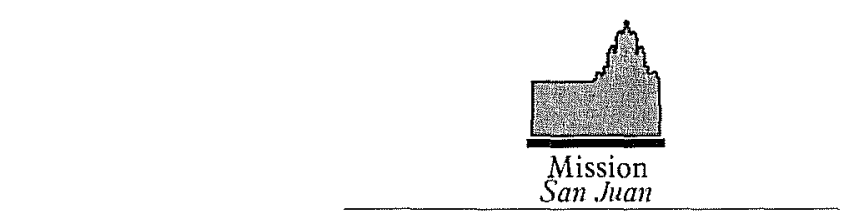

\section{Introduction}

On September 29, 1998, the Center for Archaeological Research (CAR), The University of Texas at San Antonio (UTSA) was contracted by City Public Service (CPS) to complete archaeological investigations at Mission San Juan Capistrano (41BX5) on certain areas in advance of the proposed installation of underground utility lines. On October 7, 1998, personnel from CAR began their investigations at the site. The site is located ca. eight miles south of downtown San Antonio, Texas on a terrace overlooking the east bank of the San Antonio River (Figure 1-1).

The purpose of the excavations was to test for the existence of intact, buried cultural features in advance of a planned project to place existing aboveground utility lines underground at the mission. The proposed utility trench was to run along the western periphery of the site for a distance of ca. 100 meters, connecting the utilities at the southwest corner of the chapel to an existing underground utility box located ca. 25 meters west of the northwest corner of the mission compound. Two additional trenches were to connect the underground utility box with the structure located at the northwest corner of the mission compound and with a light pole located ca. 20 meters to the southwest of the underground utility box.

Three excavation units placed to the west of the current chapel encountered wall foundations dating to the Colonial period. Another unit located in this same area exposed two well-defined Colonial period living surfaces. An additional unit, located ca. 20 meters to the west of the Priests' quarters, also encountered Colonial period wall foundations. Colonial period floors and walls were not previously known to exist in these locations. The results of the excavations indicate that there are significant amounts of intact cultural features located along the proposed route of the CPS utility trench.

\section{Historic Background}

Mission San José de los Nazonis, later renamed San Juan Capistrano, was established on July 11, 1716, in the village of Nazonis, near the present town of Cushing, Texas. The mission was founded to service the Nazoni and Nadaco natives of this region. On March 5, 1731, the Franciscan friars of the College of Querétaro relocated the mission to the east bank of the San Antonio River. Since there was already a mission named San José located only 2-1/2 miles to the north of the new location, the mission was renamed San Juan Capistrano (Figure 1-1).

The primary sources of early historical data on Mission San Juan are reports and inventories written by resident or visiting missionaries that were intended for the College of Querétaro in Mexico. Most, if not all, of the early descriptions of the mission are sketchy and it is not until 1745 that the quadrangle is described in some detail.

Fr. Francisco Xavier Ortiz came to San Juan in 1745 to inspect the mission and report his findings to Querétaro. He noted that the "church was still merely a large hall made of brush, plastered with mud, and roofed with straw; but it was well kept and very clean, and it had a tower with two bells" (Habig 1968a:166). This structure was probably constructed in 1731 or 1732 (Ivey et al. 1990:169). He additionally reported that the "friary was a modest building of stone and mortar, having two private rooms and a few others for offices." There was also a granary, which may have been a stone building, and a carpenter and a blacksmith shop (Habig 1968a:167).

Fr. Ortiz returned to San Juan in 1756 and noted that during the intervening years the jacal church had been replaced by a new church built of stone and mortar (Schuetz 1974:37). The dimensions of this church were given in varas ( 1 vara $=33.3$ inches), therefore the structure was 24 varas long ( $68 \mathrm{ft}$.) and 5-2/3 varas wide (15 ft.). In addition to the new stone church, Ortiz noted many other stone structures. However the houses 


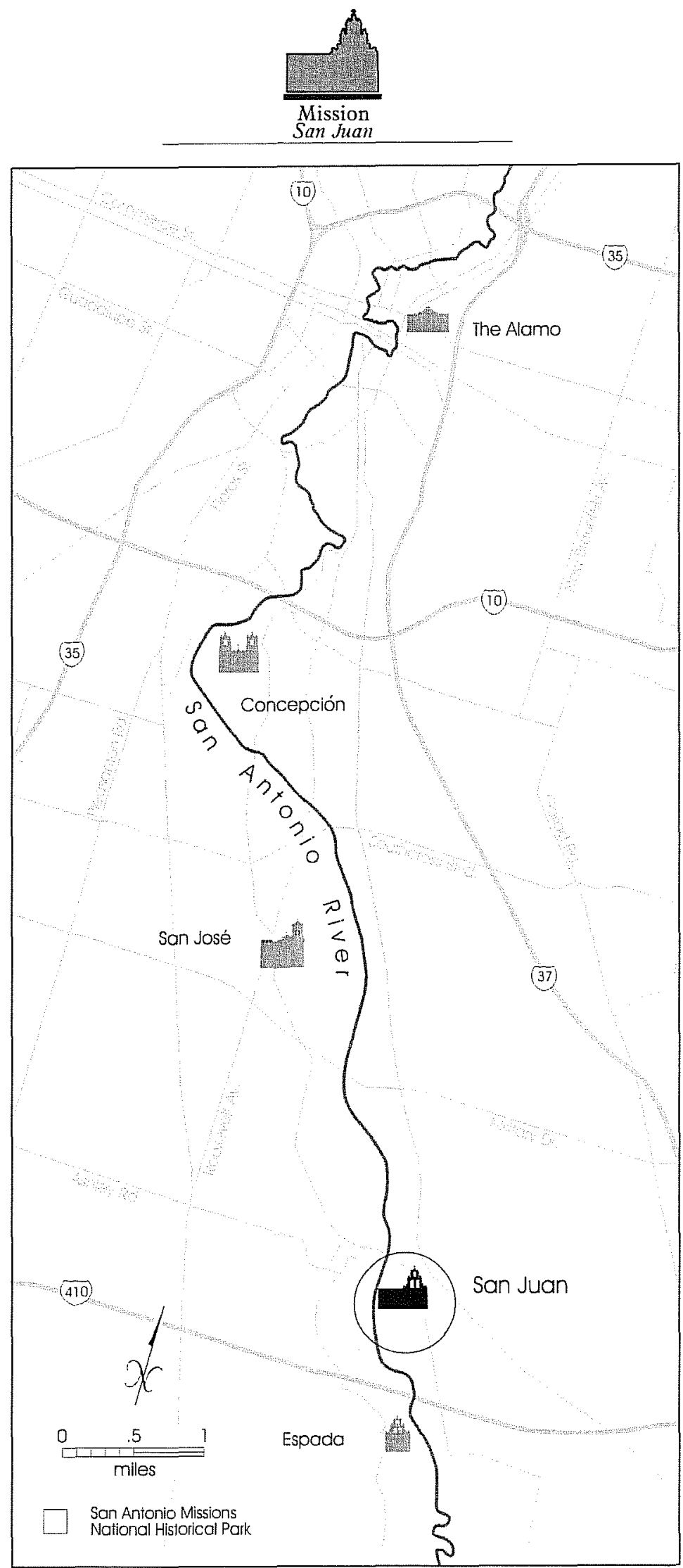

Figure 1-1. The five San Antonio Missions with Mission San Juan Capistrano highlighted. 


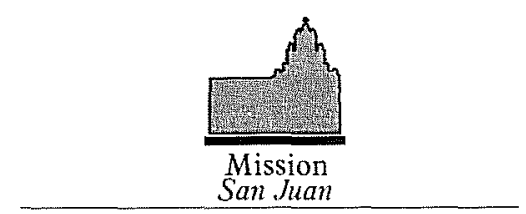

of the Native inhabitants were still jacales, and formed two streets visible from the mission (Habig 1968a:168).

In 1759, Fr. Mariano Fransisco de los Dolores y Viana visited San Juan to prepare an inventory. In his report, he provides a brief description of some of the structures of the compound (Ivey et al. 1990:174). His measurements of the church vary only slightly from those given by Ortiz in 1756. Similarly, the inventory of the contents of the church are almost identical to those described by Ortiz in 1756.

Fr. Dolores returned to San Juan in 1762 and prepared another report with yet another brief description of the structures found within the compound. In this report, he describes the structure utilized as the church as being a supplementary or temporary structure, 25 varas in length (69.4 ft.), with no measurements for width being recorded (Schuetz 1968:43). He describes the convento as being formed by "the church, sacristy, and four cells with its corridor, two offices, refectory, kitchen, workshop, and porter's lodge (Schuetz 1968:44). Additionally, he notes that the village itself is still formed of "thatched huts" until such time as the housing can be constructed of stone (Schuetz 1968:45).

The next known document describing the compound at San Juan dates to 1772 . During this year, it was agreed that Mission San Juan, as well as the other San Antonio missions under the control of the College of Querétaro, would be surrendered to the College of the Zacatecas. A full inventory of the mission was prepared for the transfer of control (Ivey et al. 1990:176). This is, perhaps, the most thorough and complete description of the compound; unfortunately, there is no map to accompany this report.

The church had evidently been replaced since the last account because here it is described as being 20 varas long (55.5 ft.), and 5 varas wide (13.9 ft.), with walls of stone and mud. The friary is described as comprising four rooms in the form of a square with an adequate patio in the center and a good well. The Friars' quarters are described as consisting of two cells, one 8.5 varas long and 5 varas wide, and another 5.5 varas long and 5 varas wide. Along the eastern side of these rooms is a covered corridor, which has 5 arches.

The inventory also lists: a guest house -5 varas square; a workshop -11 varas long and 5 varas wide; an assignment room with no measurements given; a kitchen -5 varas square; an auxiliary kitchen room also -5 varas square; a community room/workshop -12 varas long and 5 varas wide; a second workshop with no measurements given; a forge -8 varas long and 4 varas wide; and a storage shed -40 varas long and 6 varas wide. In addition to these structures, there were fifteen new houses included in the inventory, and a new pueblo was reported to be in the process of being built.

Another brief report pertaining to the compound was prepared in 1786 by Fr. José Francisco Lopez (Leutenegger 1978). He describes the quadrangle as forming a square. It is surrounded by a rampart, which was utilized as the back wall for much of the Native quarters. The church and sacristy are described as being constructed of stone and lime, and located near the convento but not joining it. This report also mentions an unfinished church and sacristy with construction having been halted due to a scarcity of building material (Leutenegger 1978). It is speculated that this is the church, on the east side of the compound, which was begun sometime between 1772 and 1779, but never completed (Ivey et al. 1990:184).

On April 10, 1794, the first and partial secularization of Mission San Juan was ordered by Comandante Pedro de Nava, and on July 14 of that year the order was carried out by Governor Muñoz (Habig 1968a:176). At that time there were 12 heads of families and approximately 36 people living in the mission (Habig 1968a:176). Each family head was given a suerte (small plot of land assigned by the luck of the draw) which measured 555.5 feet long and 277.75 feet wide. The remaining lands of the mission were to be used as a communal farm by these families. 


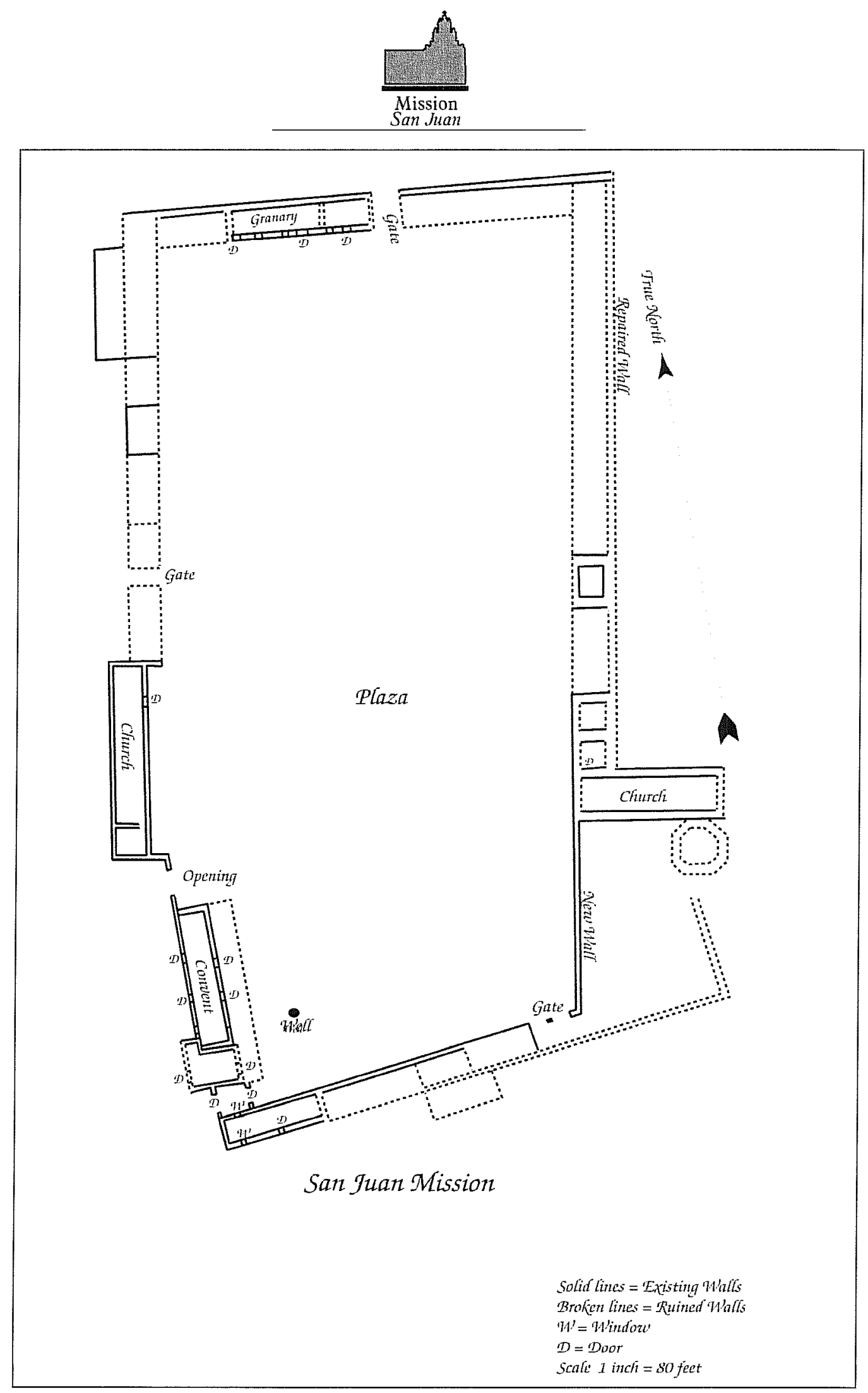

Figure 1-2. Updated rendering of 1890 William Corner map of the ruins of Mission San Juan. 


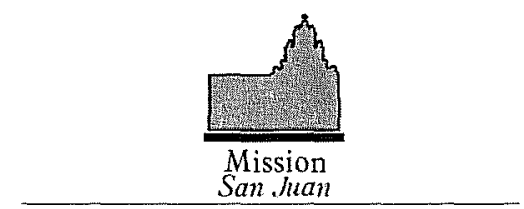

After this partial secularization, Mission San Juan no longer had its own missionary, but was attended to by the resident padre at Mission San Fransisco de la Espada. By 1809, when Governor Salcedo reported on the conditions at San Juan, the Native population had dwindled to twenty (Habig 1968a:178).

Mission San Juan Capistrano was fully secularized in 1823, and the following year Fr. Díaz de León surrendered the church and all of its furnishings to the acting pastor of San Fernando. This ended the use of San Juan as an active mission. Shortly after this, in 1831, the remaining properties of San Juan were sold at public auction, with the exception of the chapel (Habig 1968a:180). During the following years, property ownership within the mission indicates a great deal of division and subdivision. The "Tufa" house, which still stands along the wall of the compound, was constructed around 1850 . Other structures were evidently constructed and subsequently demolished prior to the complete mapping of the ruins of San Juan in 1890 by William Corner (1890) (Figure 1-2). Later accounts indicate that, while the population remained fairly low, some of the structures remained occupied throughout the nineteenth century and into the twentieth century (Thurber et al. 1993:7). During the twentieth century the Tufa house was used as a school.

By 1890, when Corner mapped the site and made notes on the condition of the mission, the chapel was in ruins (Figure 1-3). Bad weather, caused by a hurricane in 1886 , had torn the roof off the chapel. The roof was not replaced until sometime after 1907 when the Missionary Sons of the Immaculate Heart of Mary, commonly know as the Claretians, extensively restored the chapel (Thurber et al. 1993:8). The diocesan clergy took over the care of the chapel from the Claretians in 1915 and conducted additional restoration work (Thurber et al. 1993:9). Sometime after this the Archdiocese of San Antonio began buying back the individually owned properties within the mission compound. It is believed that they regained complete ownership of the entire mission shortly before 1933 (Schuetz 1968:67).

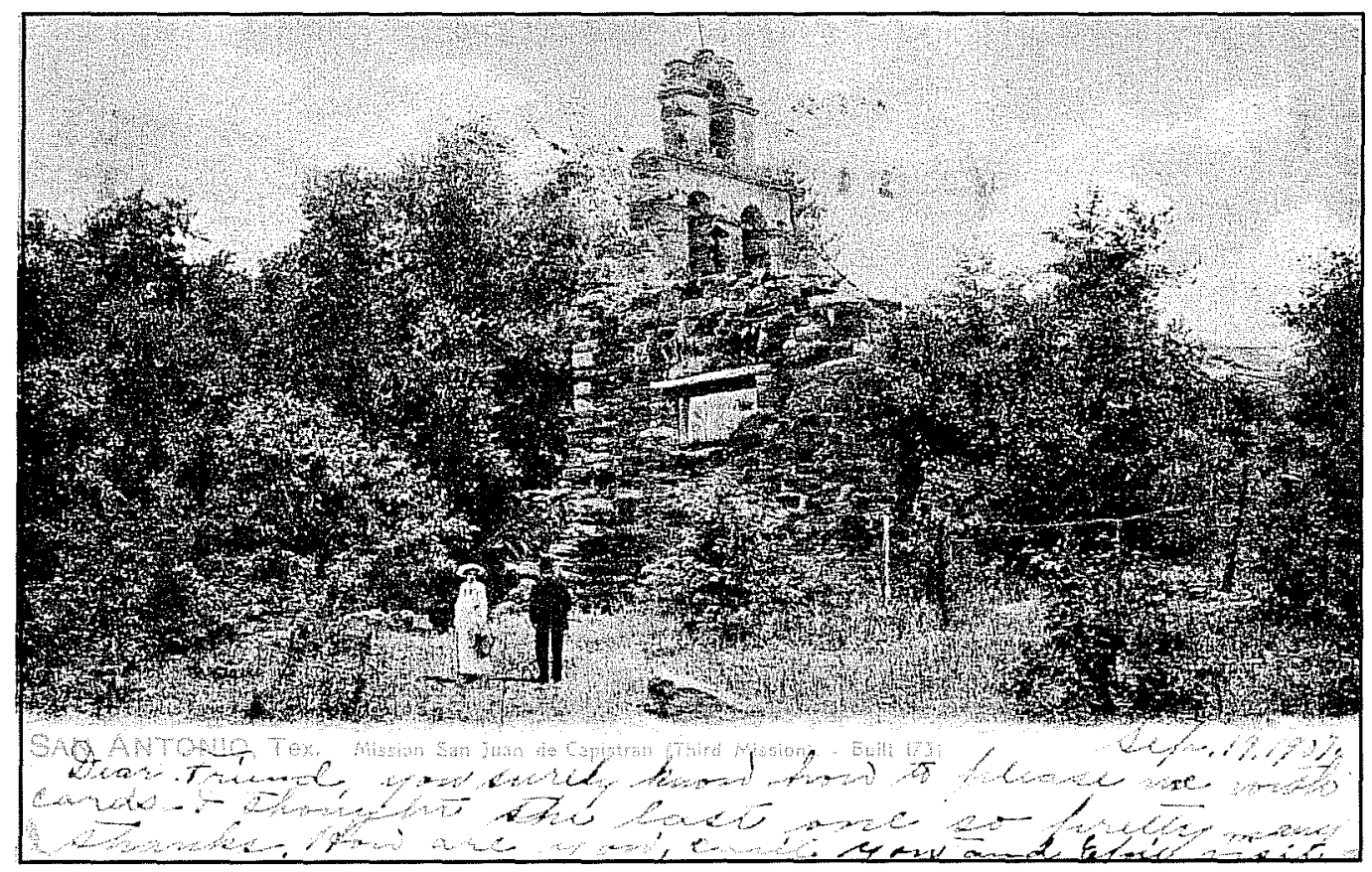

Figure 1-3. Early postcard image of the ruins of the Chapel at Mission San Juan. 


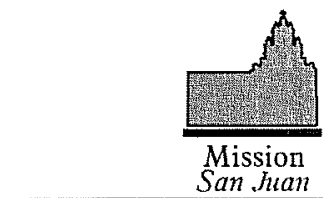

\section{Previous Investigations}

Mission San Juan has a long history of archaeological investigations. In 1933, Harvey P. Smith, an architect for the Texas Civil Works Administration and Texas Relief Commission, working under the authority of the Works Progress Administration (WPA), conducted extensive excavations at Mission San Juan Capistrano. The 1933 excavations were designed to relocate wall foundations for restoration work, which was to be completed that same year. This project helped define much of what is currently known about the layout of Mission San Juan (Figure 1-4).

The first archaeological investigation at Mission San Juan took place in 1967 under the direction of Mardith Schuetz and Curtis Tunnell. Excavations focused on: the rooms north of the current chapel, the uncompleted church on the east side of the compound (Room 26); the plaza; and in several known middens (Schuetz 1968). Some rooms were completely excavated while others were only tested. This body of work represents the first professional and thoroughly documented archaeological research project conducted at Mission San Juan (Thurber et al. 1993:283).

Schuetz returned to San Juan in September of 1968 and conducted test excavations across the front of the current chapel (Room 17), prior to the construction of support buttresses along the eastern facade of the structure (Figure 1-5). While these excavations did establish part of the construction sequence of the current eastern facade of the chapel, they did not date the construction of the chapel. Additionally, in 1968, Schuetz investigated a midden located outside the south wall of the compound, an apparent structure floor in what is currently part of the park museum (Room 18) and, the two rooms immediately to the south of the museum (Rooms 19 \& 20). She also excavated several units along the south wall to obtain additional data for restoration (Figure 1-5) (Schuetz 1980:4).

In September of 1969, Schuetz returned to San Juan with the specific goal of dating the construction of the current chapel (Room 17) (Schuetz 1974:7). This work was undertaken just prior to the complete restoration of the chapel. Schuetz had presumed that burials would be found in the floor of the chapel, and that associated artifacts would allow for the dating of the burials and therefore the dating of the chapel as well (Schuetz 1974:7). In addition to recovering extensive burial data, Schuetz discovered a complex past preceded the chapel. Schuetz concluded the structure had originally been built as something other than a church (Schuetz 1974:48).

While conducting excavations inside the chapel, Schuetz also monitored the digging of a trench for heating and air-conditioning pipes connecting the chapel (Room 17) and the museum (Room 18). This trench ran outside the compound, extending out from the west wall of the chapel, then turned south toward the museum. Strata that "might represent floor levels" were observed in the trench, and their locations were measured at 9 to 11 feet out from the west wall of the chapel (Schuetz 1974:23). Schuetz was able to correlate these strata with floors 5 and 6 inside the chapel and suggested that their depth placed them well into the Colonial period (Schuetz 1974:23).

Two years later, in 1971, Schuetz returned to San Juan, this time with the goal of completely excavating the buried portion of the convento located in the southern portion of the quadrangle (Schuetz 1980:5). These excavations led Schuetz to conclude that she had located the foundation walls of the first stone church and sacristy (Room 31) built between 1745-1756 for the mission (Figure 1-6).

Between July 1 and December 31, 1974, an archaeological and historical survey of the proposed Mission Parkway of San Antonio was conducted by personnel of the Texas Historical Commission (THC) under a contract agreement with the city of San Antonio (Scurlock et al. 1976). The main goals of this project were to present a comprehensive overview of the prehistory and history of the area included in the scope of the proposed parkway and to make recommendations 


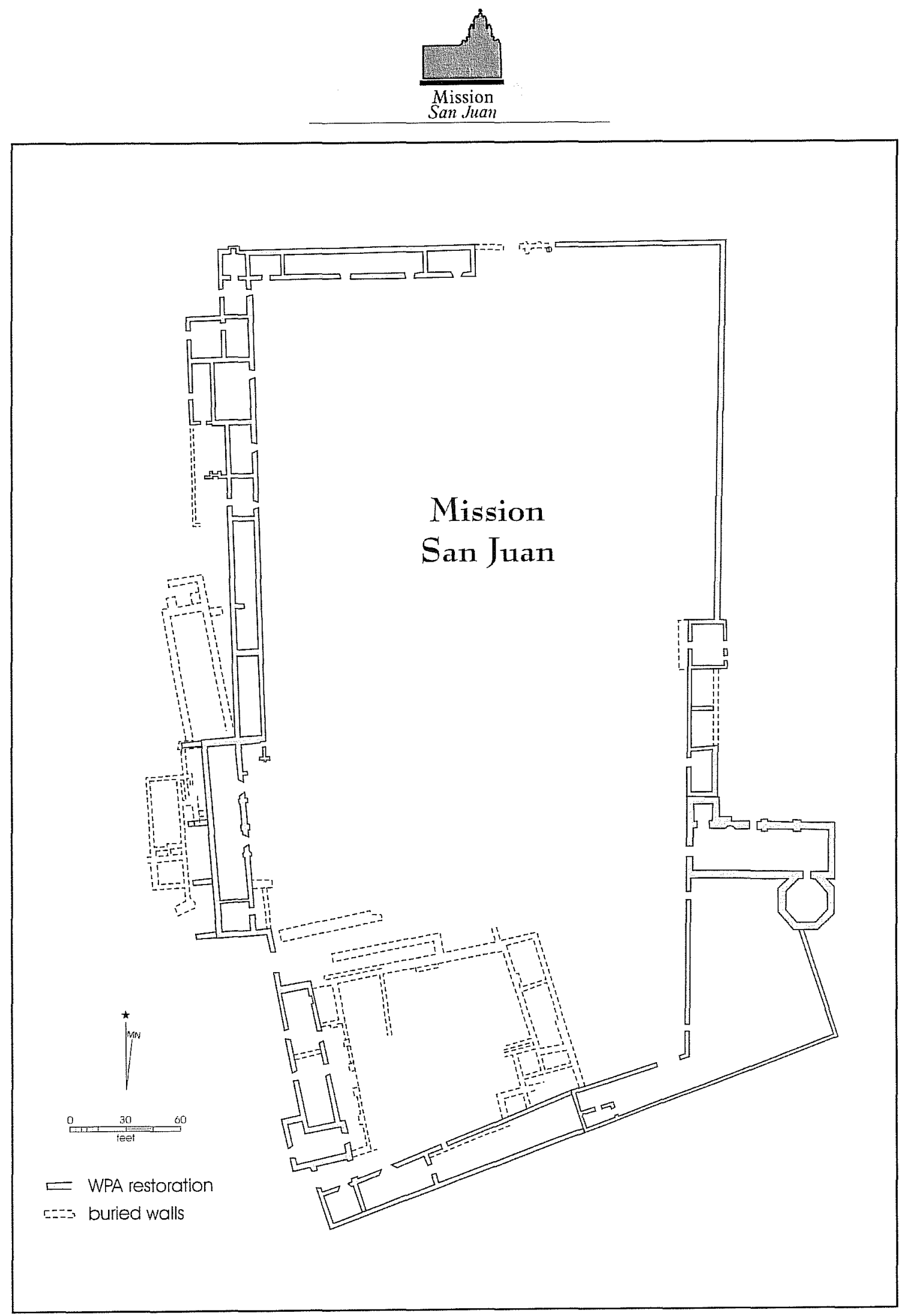

Figure 1-4. Rendering of ca. 1933 Harvey P. Smith (WPA) investigations. 


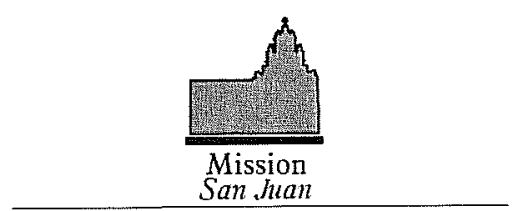

for future research and preservation projects within the Mission Parkway (Scurlock et al. 1976). During, but unrelated to the survey project, when improvements to a drainage ditch outside the north wall of Mission San Juan were made a refuse midden was encountered. This midden consisted largely of animal bone, the majority of which was domestic goat and cattle/ bison. The feature was not dated (Scurlock et al. 1976).

In March and April of 1975, Dan Scurlock directed excavations along the west side of the current chapel (Room 17) and along the eastern facade of the chapel. The purpose of these investigations was to determine if the current chapel had originally been constructed as an "open chapel" in the 1750 s, as suggested by the filled arches of the eastern facade (Scurlock 1976:6). The four excavation units placed along the west side of the chapel revealed a heavily disturbed matrix interpreted as backfill from Smith's excavations in the 1930s (Scurlock 1976:3). The results indicated that the arches had originally been constructed as open arches and that at some point they were filled in. It was concluded that the structure was originally constructed as an "open chapel" and was later converted into a "more typical European church by filling in the arches and then placing conventional door entrances in the center of two of them" (Scurlock 1976:6). This belief contradicts Schuetz's conclusions that the structure was not in use as a chapel until the end of the eighteenth century, and probably functioned as a granary prior to being converted into a chapel (Schuetz 1974:48).

Working under the authority of the National Park Service (NPS), James Ivey, in July and August of 1982, conducted additional archaeological investigations at Mission San Juan. These investigations included the re-examination of construction methods, foundation depths, wall thicknesses, and alignments within the compound, as well as the excavation of an area along the outside of the south wall. The purpose of these investigations was to help establish a clearer picture of the construction sequences of Mission San Juan for the preparation of an architectural history of the mission for NPS. (Ivey 1982:1).

The following year, in October of 1983, James Escobedo of NPS conducted an archaeological investigation in conjunction with stabilization work of the Tufa House (Room 28) (Figure 1-6) located on the east side of the compound (Escobedo 1985). This investigation included the complete excavation of the interior of the structure, and trenching around the entire perimeter of the structure. It was during these excavations a Colonial period midden was encountered and it was revealed that the structure had been built over structural remnants dating to the Colonial period.

In October of 1984, Anne Fox of the Center for Archaeological Research (CAR), The University of Texas at San Antonio (UTSA), directed the completion of a single excavation unit against the chimney of the small structure (Room 4) in the northwestern corner of the quadrangle (Figure 1-6). The purpose of the investigation was to ascertain construction information on the chimney that was pulling away from the wall. This work was required by the Texas Antiquities Committee before stabilization of the chimney could take place (Fox 1999:10).

In February of 1986, test excavations were conducted by CAR along the northern wall of the compound under the supervision of David Turner (Turner 1988). The purpose of this investigation was to determine if a construction trench proposed by City Public Service (CPS) might impact intact cultural remains. Five $1 \mathrm{x}$ $1-\mathrm{m}$ units were placed at a distance of four meters north of the north wall, spaced to cover an overall distance of twenty-six meters. As a result of these investigations several intact midden deposits were located (Turner 1988:23). It appears that the use of this area as a dump was fairly intensive during the Spanish Colonial period with intensity of use diminishing toward the close of the nineteenth century (Turner 1988: 23). 


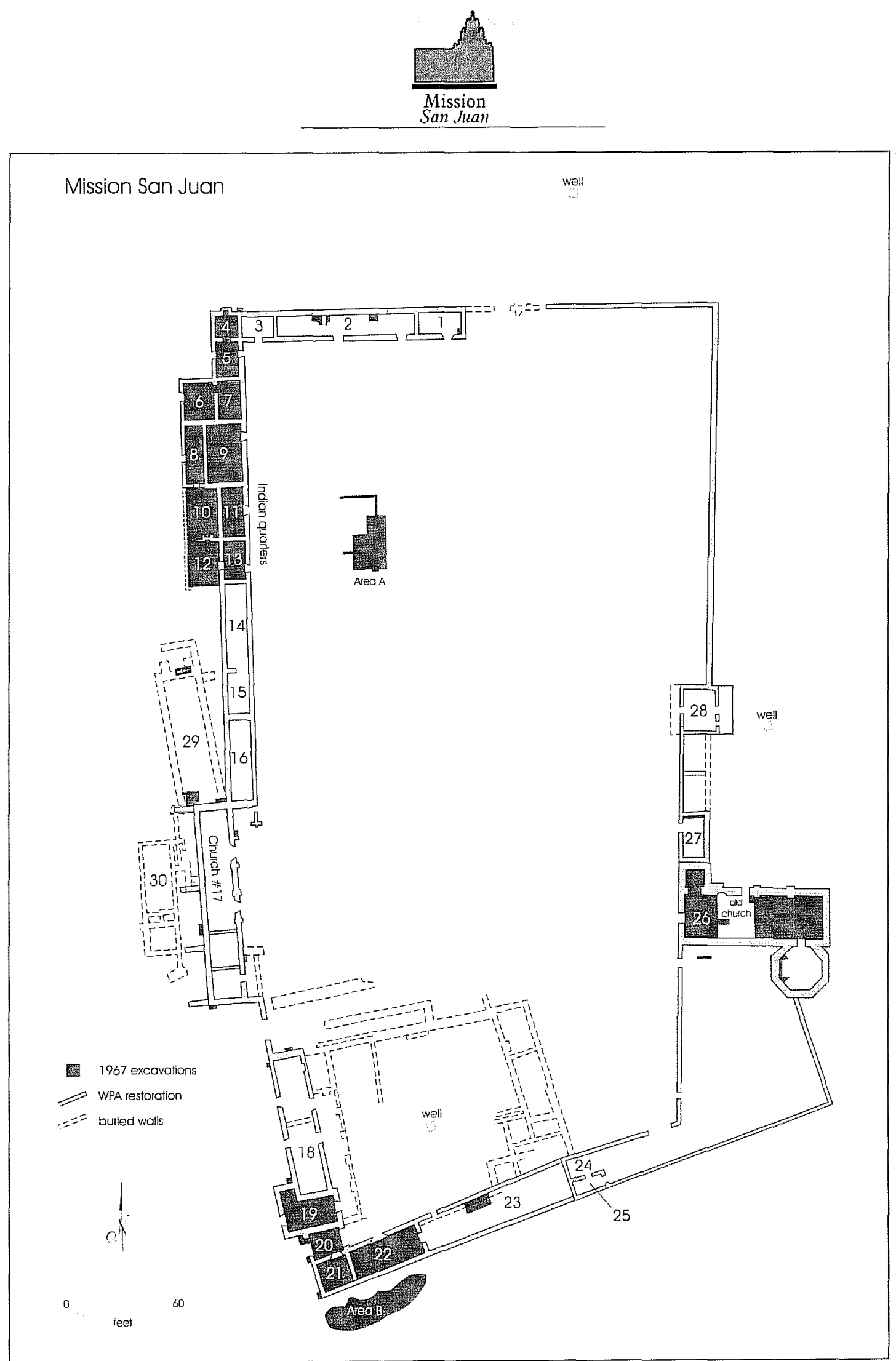

Figure 1-5. Map indicating early investigations conducted at San Juan. 


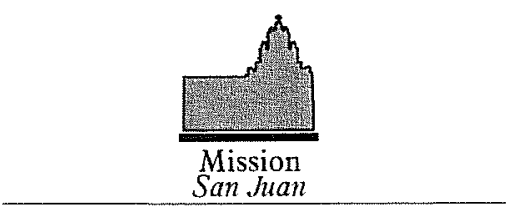

In March of 1992, Anne Fox of CAR directed excavations along the eastern wall of the compound as part of a project aimed at alleviating drainage problems within the mission compound (Fox 1993). Four separate areas were tested near the eastern wall (Figure $1-6)$. Of these excavations one unit just south of the Tufa house, revealed a portion of the original eastern wall foundation of the compound. This finding confirmed that the buried wall foundation located by Escobedo in 1985 was probably part of the original eastern wall of the compound. Monitoring of the grading for drainage swales was also carried out as part of this same project. The monitoring revealed a surface scattering of artifacts, dating primarily from about the turn of the twentieth century to the $1940 \mathrm{~s}$, located just north of the northeast corner of the ruins of the chapel (east side of the compound) (Figure 1-6). Fox attributes this late trash midden to date to the late occupation of the Diaz house (Fox 1993:22).

In October 1996, Kevin Gross, CAR archaeologist, completed preliminary investigations south of the mission quadrangle in an area specified for a proposed 800-foot drainage channel (Gross 1998). Shovel tests excavated at 5-m intervals along this route revealed a limited amount of Colonial period and modern artifacts in a mixed context (Gross 1998:4).

In November 1997, Diane Cargill of CAR, supervised archaeological testing necessitated by NPS plans to construct a new service drive which would connect Padre Drive with an existing parking area located on the outside of the northwestern portion of the compound (Cargill and Robinson 2000). A total of three 3-x-3 foot units, 14 shovel tests and one backhoe trench were excavated in the area to be impacted. Three trash deposits, dominated by nineteenth and twentieth century artifacts, were encountered. No intact Colonial period deposits were revealed by these investigations (Cargill and Robinson 2000).

In addition to these works, additional research on bone collagen has been conducted by Diane Cargill and is presented in the form of a Master's Thesis for the
Department of Anthropology, The University of Texas at San Antonio (Cargill 1996). This research focuses on the analysis of human bone recovered from the "old church" or Room 26 of the mission compound. In an attempt to assess mobility versus permanency of Native American mission residents during the Colonial period, Cargill utilized carbon and nitrogen stable isotope analysis to determine the diet of those individuals interred in Room 26 (Cargill 1996). Her research concludes that the individuals examined do not fit the profile for permanent mission residents existing on a maize and cattle diet as is often asserted (Cargill 1999). The carbon and nitrogen levels present in these individuals appears to be more in line with populations dependent on marine or freshwater fauna (Cargill 1999).

Jeffrey Francis, CAR archaeologist, is also conducting additional research on previously recovered human remains. This research includes the examination of human remains from the current mission chapel, or Room 17. The purpose of this research is to verify ethnohistorical accounts of a demographic shift in mission populations to a more ethnically diverse population (Francis 1999). To date, this research reveals that 14 of the 27 adult remains included in this study display characteristics common to Native American ancestry, while 13 have been identified as being of Caucasoid or admix ancestry (Francis 1999).

\section{The Scope of Work}

In light of the proposed trenching for the placement of underground utilities by CPS at the site of Mission San Juan Capistrano, an archaeological investigation was required to determine what, if any, impact this work might have on intact Colonial or Prehistoric buried remains. A systematic testing plan covering the area to be impacted was designed. This plan consisted of the following:

1) Excavate three $1 \times 1-\mathrm{m}$ units along the planned route of the trench behind the current chapel to 


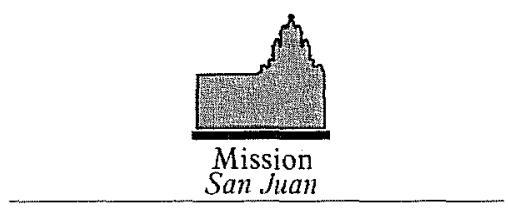

identify and collect data from undisturbed Colonial deposits possibly located in this area;

2) Excavate four $1 \times 1-\mathrm{m}$ units in the vicinity of the open manhole vault to investigate a cultural deposit which was visible in the wall profiles of the vault at a depth of approximately $170 \mathrm{~cm}$ below the surface; and

3) Excavate twelve shovel tests at five-meter intervals along the proposed trajectory of the trench where it extends through the drive/parking area south of the manhole vault and west of known existing Colonial features.

\section{Methodology}

To determine the possible impact of trenching in the area west of the current chapel, three $1 \times 1-\mathrm{m}$ units were placed in alignment with the proposed trench (Figure 1-6). Units 1-3, as well as all other excavation units in the project, were hand-excavated in arbitrary $10 \mathrm{~cm}$ levels unless identified cultural remains dictated otherwise. All soil was screened through 1/4-inch wire mesh and all recovered artifacts were brought back to the laboratory at CAR for analysis and curation.

Unit 1 was placed 10 meters west of the southwest corner of the chapel and was excavated to a depth of $50 \mathrm{~cm}$ below surface (bs). Unit 2 was placed 10 meters west of Unit 1 and was excavated to a depth of $40 \mathrm{~cm}$ bs. Unit 3 was located 10 meters north of Unit 2 and was excavated to a depth of $30 \mathrm{~cm}$ bs (Figure 1-6).

At the location of the manhole vault at the northern end of the property, cultural material was observed in the northwest and southwest walls of the vault. To determine the nature of this material, two $1 \times 1-\mathrm{m}$ units were placed in these locations. Unit 4 , on the northwest side of the vault, was excavated to a depth of $210 \mathrm{~cm}$ bs. Unit 5, on the southwest side of the vault, was excavated to a depth of $130 \mathrm{~cm}$ bs (Figure 1-6). 

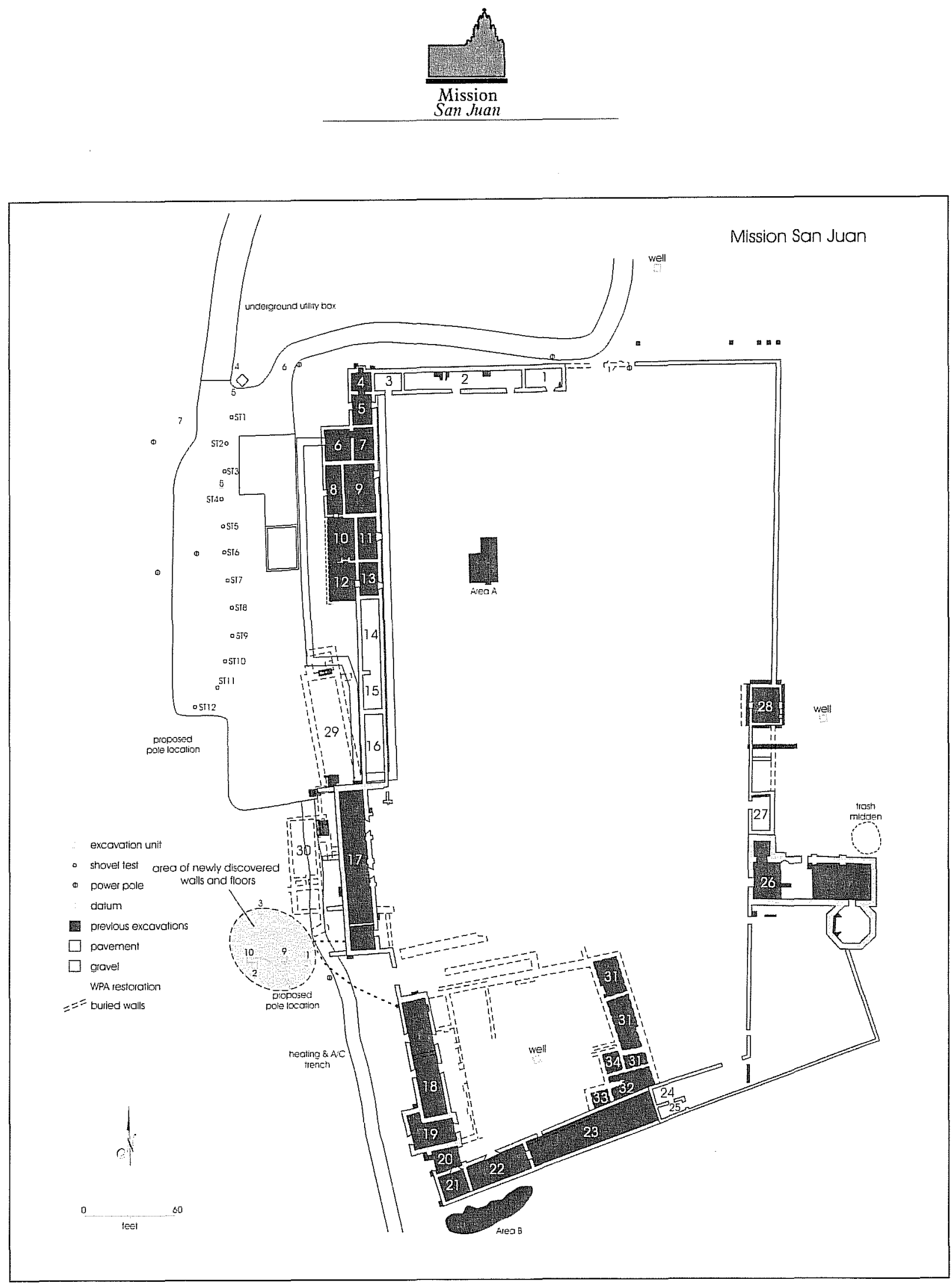

Figure 1-6. Map indicating current project excavations. 


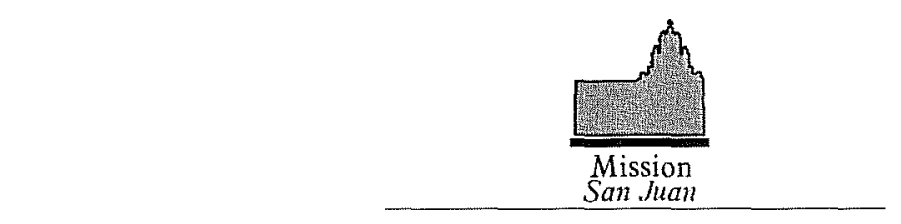

\section{Geophysical Survey}

In addition to hand excavation techniques, a geophysical site survey utilizing multifrequency electromagnetic ground sensing was conducted to assist in locating buried features in the area proposed for utility excavation. This geophysical imaging process provides a non-invasive, two dimensional screening of sub-surface ground conditions. The device operates in a frequency band between $330 \mathrm{~Hz}$ to about 20,000 $\mathrm{Hz}$. The lower frequencies provide a depth sounding or "frequency sounding" capable of penetrating further into the ground to detect deeply buried anomalies. The high frequency signal travels only a short distance and, thus, is more successful at detecting shallowly buried anomalies. Sixteen frequencies falling within the above-mentioned range were utilized in the tests conducted at Mission San Juan.

The geophysical survey, conducted by Bull's Eye Enterprises, Inc., of San Antonio, resulted in the production of a composite color map which showed the presence of an anomaly, possibly representing a manmade structure, beneath the surface in the area of the manhole vault (Figure 1-7). To investigate this possibility, Unit 6, a 1 x 1-m excavation unit, was placed seven meters due east of the southeast corner of the manhole vault (Figure 1-6). Because the unit was to be excavated to a depth in excess of four feet, a $50 \mathrm{~cm}$ x 1-m step-down was placed on the north and south

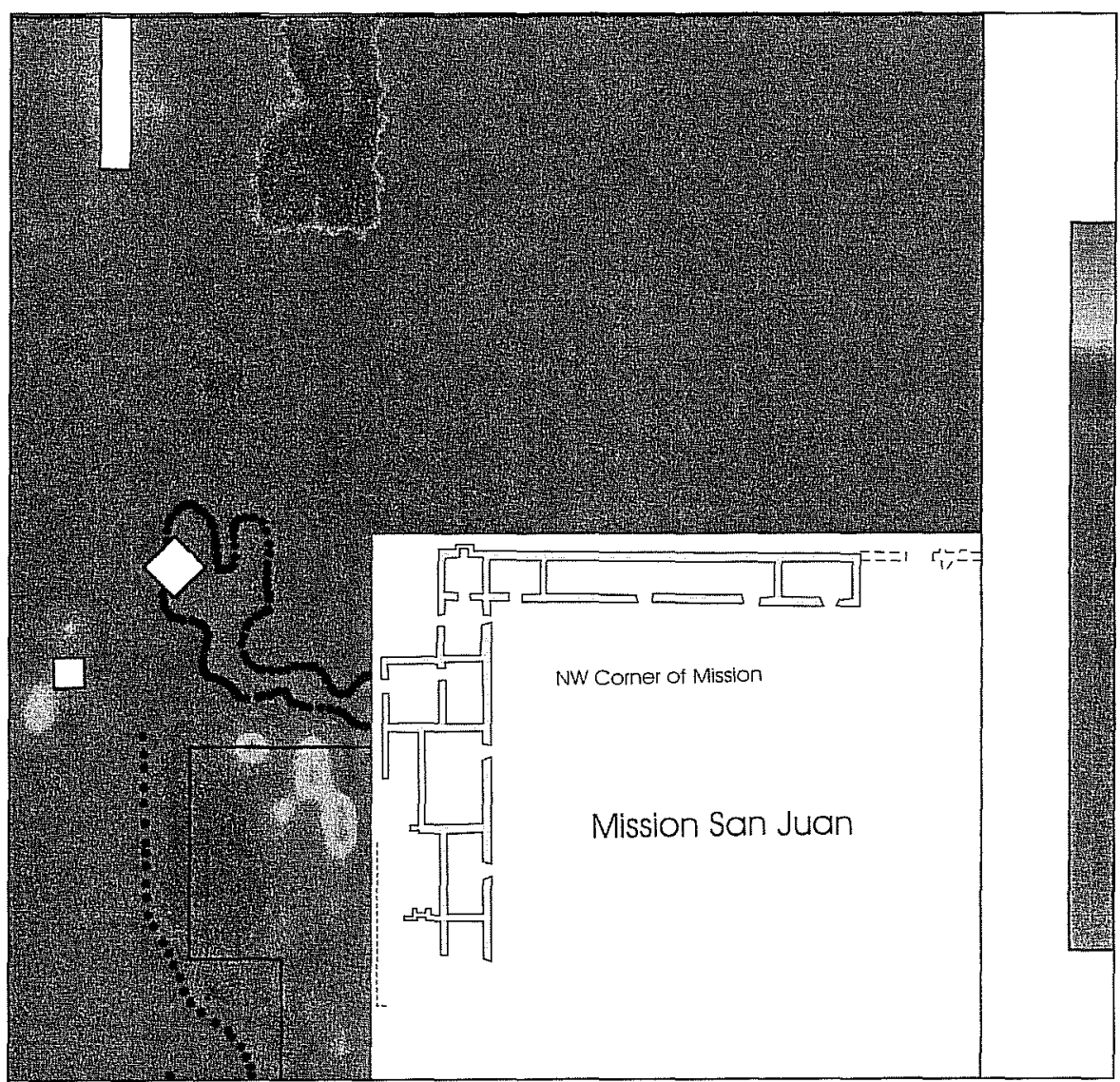

Figure 1-7. Composite map from geophysical survey.

Note: White areas represent CPS utility excavation areas. 


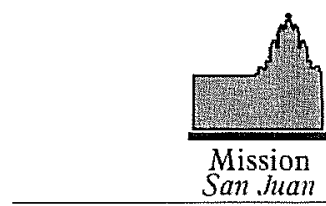

sides of the unit to comply with Occupational Safety and Health Act (OSHA) regulations. These step-downs were excavated separately from the $1 \times 1-\mathrm{m}$ unit and were designated as Units $6 \mathrm{a}$ and $6 \mathrm{~b}$. These were excavated in one level to a depth of $40 \mathrm{~cm}$ bs. Unit 6 was excavated in $10 \mathrm{~cm}$ levels to a depth of $165 \mathrm{~cm}$ bs.

Unit 7 was a $1 \times 1-\mathrm{m}$ unit placed approximately 15 meters to the southwest of the manhole vault. It was placed in an area designated for the installation of a new light pole (Figure 1-6). This unit was excavated to a depth of $90 \mathrm{~cm}$ bs.

Units 9 and 10 were placed in the vicinity of Units 1 and 2 in areas designated for the installation of new utility poles (Figure 1-6). Unit 9 was situated approximately 12 meters west of the southwest corner of the chapel and was excavated to a depth of $110 \mathrm{~cm}$ bs. Unit 10, excavated to $90 \mathrm{~cm}$ bs was approximately 21 meters west of the southwest corner of the chapel.

A series of twelve shovel tests (STs), numbering 1 through 12, were placed at 5 meter intervals through the parking area to the west of the existing Priests' quarters (Figure 1-6). These shovel tests were placed along the proposed trajectory of the underground utility trench and were excavated to a depth of $50 \mathrm{~cm}$ bs. When a segment of wall foundation was revealed in ST 4, an excavation unit designed to test for intact cultural deposits (Unit 8) was placed adjacent to it. Unit 8 was a $1 \times 1.5-\mathrm{m}$ unit with the long axis running east to west (Figure 1-6). It was approximately 20 meters south of the manhole vault. Unit 8 was excavated to a depth of $70 \mathrm{~cm}$ bs.

The locations of all excavation units and shovel tests were recorded and mapped with the use of an Electronic Distance Measuring/Total Data Station (EDM/TDS) which tied the excavations into the existing structures of the mission (Figure 1-6). This recording method also allows for vertical control of data from one unit to another. In this manner we were able to compare Colonial period strata horizontally across the site regardless of present-day surface contouring.

Artifacts recovered from all excavation units and shovel tests were labeled and bagged and returned to the CAR laboratory. Level record forms were kept for all excavation units and shovel tests, and a daily work narrative was recorded by the project archaeologist.

In the laboratory, the artifacts were washed, labeled, and cataloged on standard historic artifact forms utilized by CAR. Artifact analysis included typing and dating of ceramics, categorizing lithic artifacts, and identifying and quantifying faunal material. All field notes, archival notes, photographs, artifacts, and laboratory records pertaining to these investigations at Mission San Juan have been curated at CAR.

\section{Special Analyses}

Two soil analysis procedures were conducted on samples taken from Unit 9. This unit was selected for testing because it contained several flooring episodes, which generally result in improved preservation beneath these sealed contexts. The two procedures were:

1) Oxidizable Carbon Ratio (OCR) testing; and

2) Phytolith testing.

\section{OCR Dating}

Twelve samples were collected from Unit 9 for OCR dating. OCR dating procedures are a relatively new development in dating charcoal found in soil. The procedure introduces a means of improving the interpretation of radiocarbon data, and is seen as a potential solution to the temporal limitations of standard radiocarbon dating. These limitations have generally been seen to create unreliable ${ }^{14} \mathrm{C}$ dates the closer one gets to the present. 


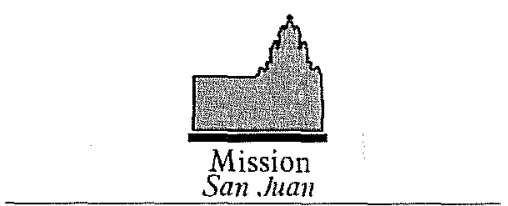

The biological recycling of organic carbon is fundamental to almost all biological systems. The OCR procedure measures the effect of the biochemical degradation of charcoal and soil humic material by examining the ratio of the total organic carbon to the readily oxidizable carbon found in the soil sample (Frink 1994:17). The rate of biochemical breakdown will vary within the specific physical and environmental contexts of the sample. An age estimate of the organic carbon is determined through a systems formula that accounts for the biological influences of oxygen, moisture, temperature, carbon concentration, and the reactivity of the soil (Frink 1992:67). Residual influences on this system are included through a statistically derived constant (Frink 1994:17). Using this method, it is then possible to assign a chronological sequence to soils dating from the present and continuing back through time.

\section{Phytolith Analysis}

Ten samples were collected from Unit 9 for phytolith analysis. Phytolith analysis is a method of examining soils and extracting organically derived phytolith silicates left in the soil by decaying plants. Certain $\mathrm{C} 3$ and $\mathrm{C} 4$ grasses have been identified by phytolith remains and clearly indicate the nature of past grassland environments in archaeological and geological sediments (Twiss 1983).

Phytolith data from Choke Canyon Reservoir have been used to propose a pattern of short versus tallgrass occurrences through time and conjecture alternating wet and dry episodes (Robinson 1982). Through the analysis of phytolith remains, it is possible to interpret the climatic conditions prior to Spanish contact in and around Mission San Juan. It is also possible to recognize changes in land use after the occurrence of Spanish influence. Such data also makes it possible to address issues of diet during both pre- and post-contact periods. A total of eight sediment samples were submitted to Texas A\&M University for phytolith analysis. These samples were collected from distinct floors or sealed horizons. It was anticipated that this analysis would provide insight into Prehistoric plant use in the mission area, as well as shed information on past activities in the room where these sediments were collected. Although artifactual evidence is scant, it is thought that these sediments represent deposits dating from contact period or early-Mission through late-Colonial times. 


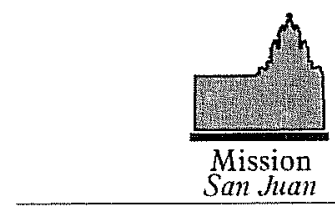

\section{Excavations Related to the West Side of the Chapel: \\ Units $1,2,3,9$, and 10}

Units $1,2,3,9$, and 10 were all excavated in the sloping terrain to the west of the Chapel (Figure 1-6). In Unit 1 disturbed deposits were encountered to a depth of $50 \mathrm{~cm}$ bs, and a Colonial period wall foundation was uncovered beginning at $38 \mathrm{~cm}$ bs. The nature of the disturbance in this area is unknown, but may be related to trenching which took place during the installation of underground heating and air conditioning pipes in October, 1969. The orientation of the foundation could not be determined, but it is postulated, because it roughly aligns with the south wall of the chapel, that it is in an east-west orientation and is an extension of the extant southern wall of the chapel.

The ground contour in this area displays a slight downward slope toward the west (i.e., toward the river) and the ground elevation is $33 \mathrm{~cm}$ lower at Datum 2 (Unit 2) compared to that of Datum 1 (Unit 1). Excavation of Unit 2 showed some modern disturbance in the upper $20 \mathrm{~cm}$, and revealed a Colonial period wall foundation beginning at a depth of $11 \mathrm{~cm}$ below surface. This wall foundation appears to be in alignment with the wall foundation revealed in Unit 1, following the same east-west orientation with the southern wall of

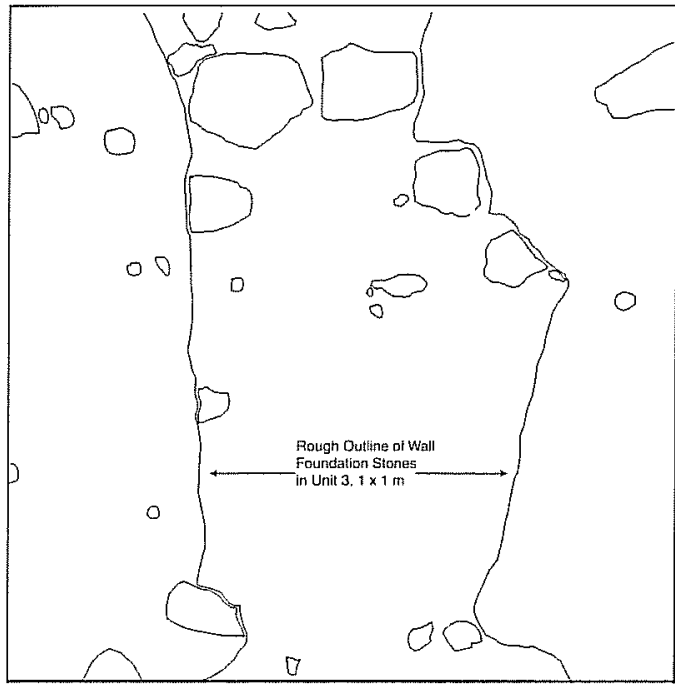

Figure 1-8. Representative diagram of wall foundation stones (Unit 3).

the chapel. Considering the $33 \mathrm{~cm}$ elevational difference in ground level, the wall foundation in Unit 2 was encountered only $6 \mathrm{~cm}$ lower than in Unit 1 . This may be an indication that the wall foundation is better preserved as it gets closer to the extant walls of the chapel. It is also known that stones were frequently robbed from abandoned structures and utilized in new construction. If early "stone robbers" had removed foundation stones, this may have been the cause of the variation in the depths at which wall foundations were encountered (Figures 1-8 and 1-9).

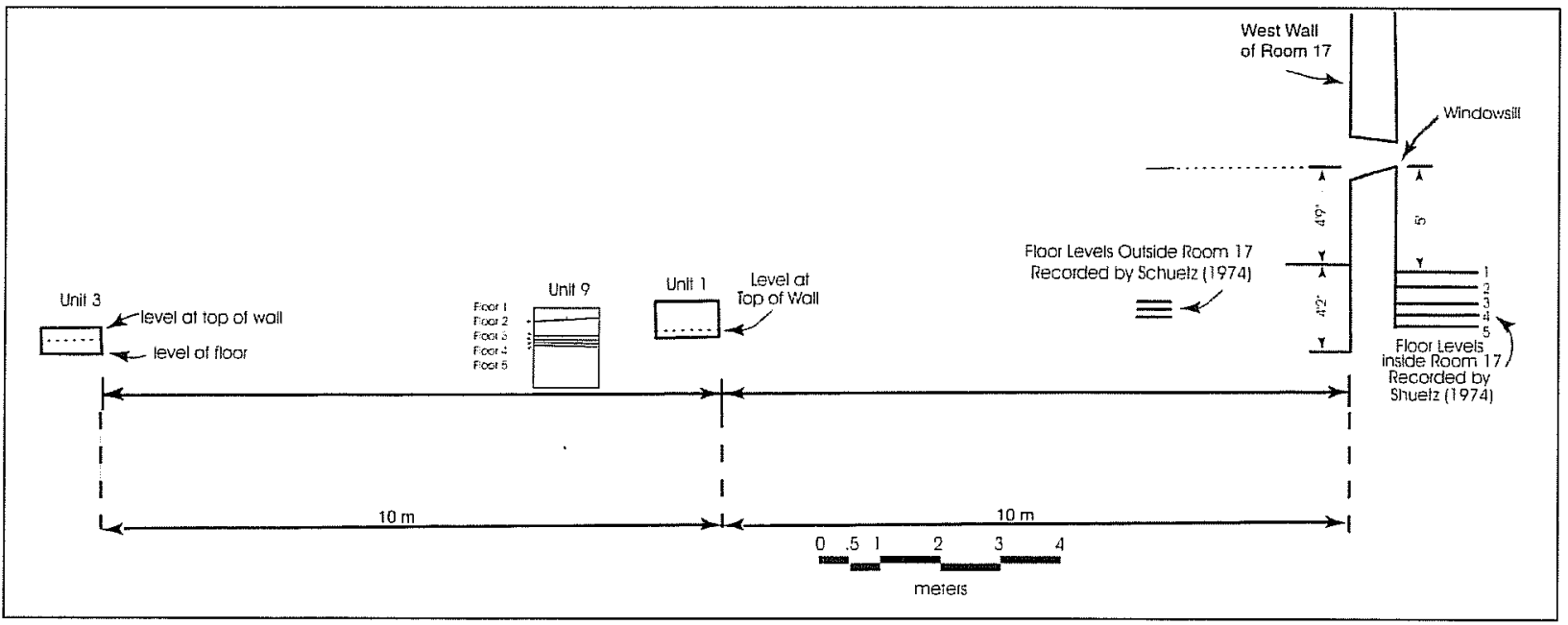

Figure 1-9. Profile map of Units located west of the Chapel. 


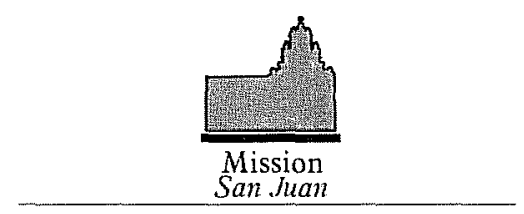

Situated immediately adjacent to the northwest corner of Unit 2, Unit 10 was excavated to a depth of 90 $\mathrm{cm}$ below surface. Artifacts encountered in this unit represent a mix of eighteenth and nineteenth century periods. The matrix in the upper $60 \mathrm{~cm}$ consisted of Colonial period construction fill. It is suspected that the wall foundation located in Unit 2 may have been a corner or an intersection of two walls and that it also extended to the north. If this is true -then the construction fill located in Unit 10 may represent wall fall. Large concentrations of Colonial period mortar along the eastern edge of the unit may represent the western side of the suspected north-south running wall, thus lending support to the idea that the wall foundation here represents a corner or possibly an intersection of two walls.

The location of another segment of wall foundation in Unit 3,10 meters to the north of Unit 2, also lends support to the idea of a north-south oriented wall abutting an east-west running wall at the location of Unit 2 (Figure 1-6). In Unit 3, a Colonial period wall foundation was encountered at a depth of $18 \mathrm{~cm}$ below ground surface (Figure 1-8). Calculating the difference in ground elevation between Units 2 and 3 places the wall $21 \mathrm{~cm}$ higher in Unit 3. As with the elevational difference between the wall foundation heights in Units 1 and 2 , this difference may be attributed to differential preservation, and/or the degree of early stone robbing. A mixture of modern and Colonial artifacts was recovered from the upper $10 \mathrm{~cm}$ bs. Below this level, a mix of Colonial and early nineteenth century materials was encountered. A floor (Floor 1) was located at a depth of $20 \mathrm{~cm}$ bs on the eastern and western sides of the wall foundation, indicating that the wall is possibly an interior wall with rooms both to the east and further out to the west. The unit was excavated to a depth of $30 \mathrm{~cm}$ bs.
Situated 3.5 meters to the northwest of Unit 1, Unit 9 was excavated to a depth of $110 \mathrm{~cm}$ bs (Figure 1-6). This unit appears to be located on the inside of a roomblock as it contained five possible flooring episodes but no wall foundations (Figure 1-9a). Floor 1 was located just below the humic layer and is extremely ephemeral. The packed-earth surface may represent an area, which experienced heavy trampling, but was never used as a floor in the traditional sense. Due to bioturbation, it appears that modern artifacts have somehow penetrated this floor and are located both above and beneath it. For this reason, it is unclear what date period to assign to this surface. Floor 2, located at approximately $30 \mathrm{~cm}$ bs, however, creates a barrier between the modern/mixed context above and the eighteenth and early-nineteenth century context below.

In Level 6 of Unit 9, a concentration of animal bone was encountered lying on top of a well-prepared floor surface. This deposit has been interpreted as representing a period of abandonment when this area may have been used as a refuse dump. The majority of bones recovered from this level are bovine, presumably cow remains.

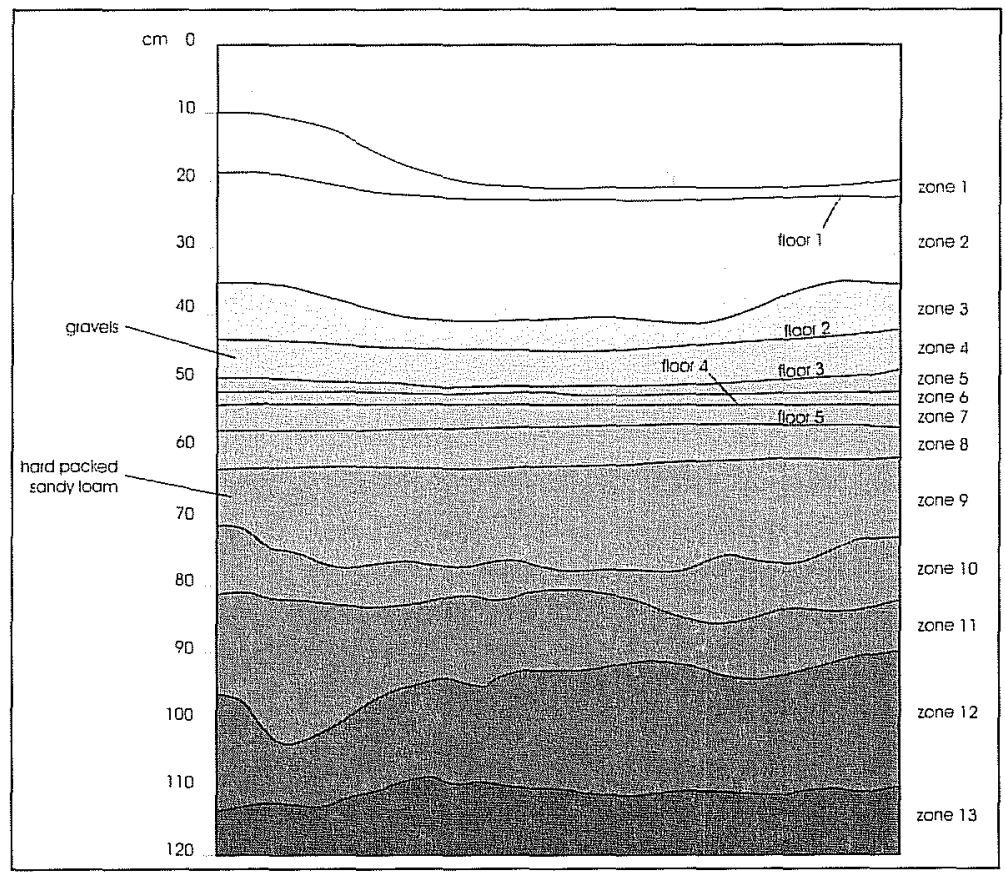

Figure 1-9a. San Juan, West profile of Unit 9. 


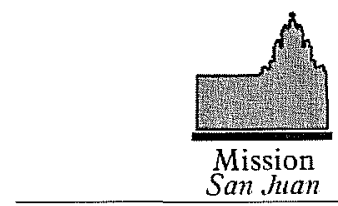

Accounting for the variation in elevations at ground level, Floor 2 in Unit 9 and Floor 1 in Unit 3 are located at exactly the same depth. Given the close proximity to one another, the eastern portion of Unit 3 and the entirety of Unit 9 may fall within the same room-block, as indicated by the common floor level. To confirm this supposition further excavation would have to be undertaken in and around Units 3 and 9.

In an attempt to compare the floor levels revealed in Units 3 and 9, to floors both inside and outside the chapel (Room 17) previously excavated by Schuetz in 1974, a scaled profile showing floor elevations was drawn (Figure 1-9). Working from the same elevation as Schuetz (1974:23) (windowsill in west wall at southern end of chapel) the current excavations were then tied into the previous excavations. By using a display of all floor elevations in a profile, it can be observed that the three strata recorded by Schuetz (1974:23) outside the chapel align with Floors 3, 5, and 6 recorded inside the chapel. The comparison of these elevations to the floor levels found in Units 3 and 9 indicates that all floors found in Units 3 and 9 lie geographically lower than the previously recorded floors inside and outside the chapel (Figure 1-9).

Quite a difference has been found in the appearance of floors in various rooms at San Juan. Nearly all have been found to be constructed primarily of small gravels and caliche, a technique customarily called chipichil or lime concrete (George 1975:47). Differences in their appearance seem to be the result of years of wear, and later attempts at repair and restoration by patching with caliche or sometimes covering with soil and constructing a new floor on top. Schuetz (1968 and 1980) describes floors in rooms nineteen through twenty-two as follows:

Room 19 - Polished floors of caliche and gravel.

Room 20 - Cobblestone paving (this was actually an entrance way, not a room).

Room 21 - Plastered chipichil floor, plaster over small river cobbles.
Room 22 - Tamped earth floor, 3-4 inches below "colonial" floor (no description of latter included).

While in Units 3 and 9 of this project, the floors seem to have been made the same way:

Unit 3 - Packed caliche mortar with small cobbles.

Unit 9 Level 2

Heavily eroded floor with small rounded cobbles.

\section{Levels 4 and 5}

Smooth caliche above a solid layer of rounded gravel.

\section{Level 6}

Flat, well-prepared floor (no further description in the notes).

It is interesting to note that Schuetz recorded the floors in the Chapel (1974) as being tamped earth, rather than chipichil.

\section{Manhole Vault \\ Units 4 and 5}

Units 4 and 5 were excavated adjacent an existing CPS manhole vault (Figure 1-6). Unit 4 was positioned on the northwest side of the vault and excavated to a depth of $210 \mathrm{~cm}$ bs. In this unit a ca. $10 \mathrm{~cm}$ thick layer of gravel road base was exposed directly beneath the surface (Figure 1-10). Beneath this layer of road base lay several layers of gray to dark grayish brown clay soil. Artifacts recovered from this unit indicate a level of modern disturbance to a depth of $30 \mathrm{~cm}$ bs. Beyond this depth, artifacts consist primarily of a mixed deposit of eighteenth and nineteenth century ceramics to a depth of ca. $90 \mathrm{~cm}$ bs. No cultural material was recovered below $90 \mathrm{~cm}$; but geomorphological features possibly representing an ancient river or stream, were recorded. The obtuse angle at which the 


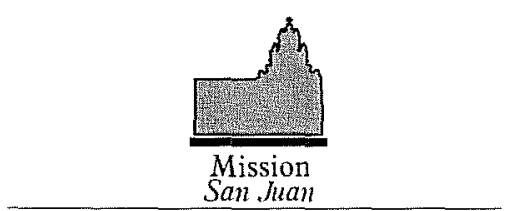

excavation unit encountered the channel made it extremely difficult to determine its previous course, however the possibility exists that prehistoric materials may be present within this buried alluvial deposit.

Excavation of Unit 5, southwest of the vault, revealed a layer of gravel road base similar to that exposed in Unit 4. Also, this unit contained a layer of animal bone, primarily bovine, in Levels 3 and 4 . No flooring episodes were encountered in this unit and it is presumed that the deposit of bone represents a refuse dump. A mixture of eighteenth and nineteenth century artifacts was recovered from just beneath the gravel road base to a depth of $90 \mathrm{~cm}$ bs. The depth, at which, the Colonial artifacts in this unit were recovered mirrors that of Unit 9 located approximately $100 \mathrm{~m}$ to the south, and indicates that the western side of the San Juan mission compound experienced a long episode of Colonial period activity.

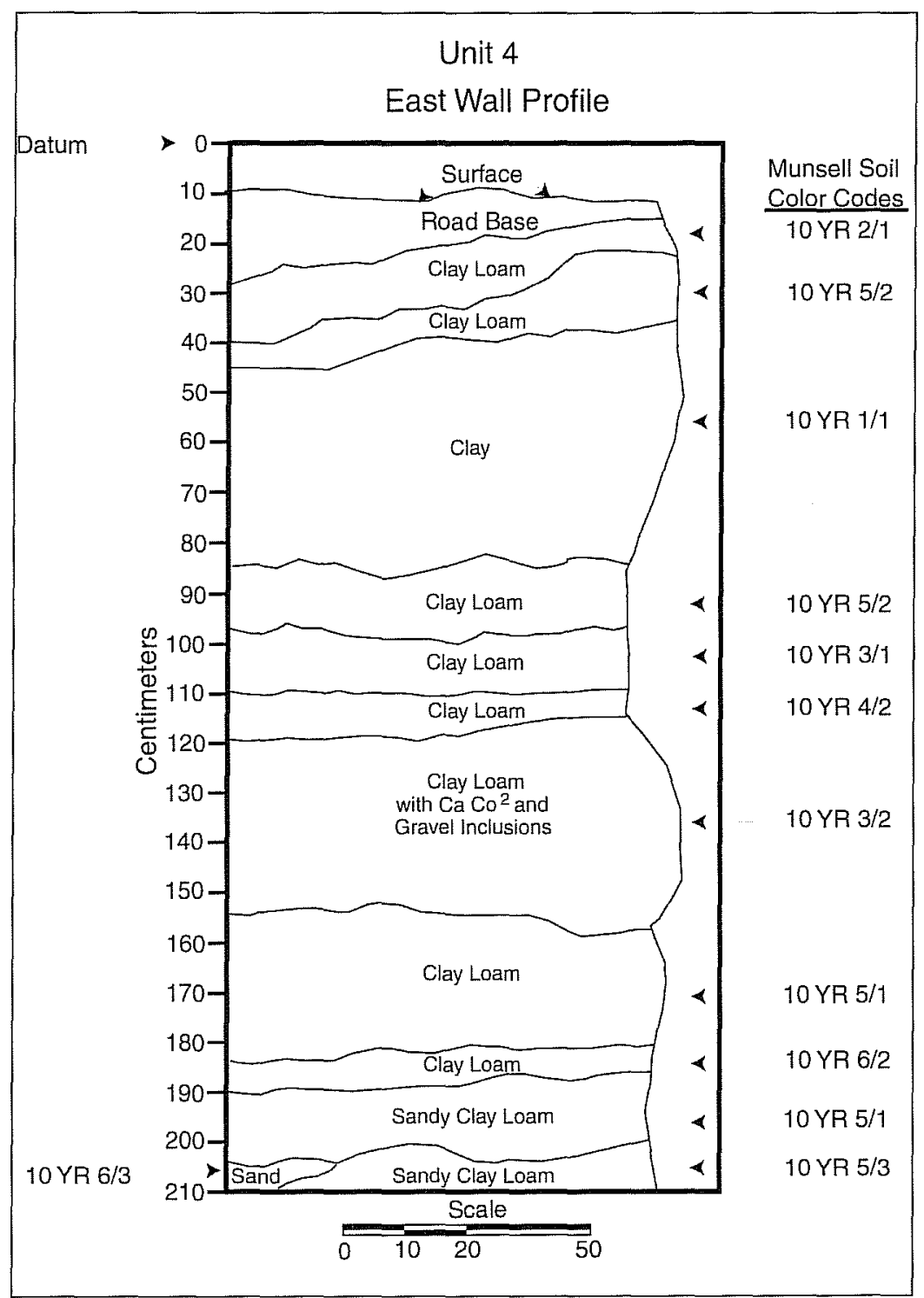

Figure 1-10. East wall profile of Unit 4. 


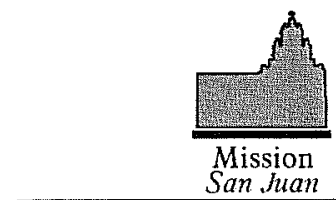

Buried Conductive Anomaly:

Unit 6

Unit 6 was excavated to investigate a buried anomaly indicated by the multi-frequency electromagnetic geophysical survey. The anomaly appeared to the east and south of the existing manhole vault (Figure 1-7). This unit, located ca. $10 \mathrm{~m}$ east of Unit 5 , revealed the same

gravel road base found in Units 4 and 5. Beneath the road base this unit contained a mixture of Colonialand Historic period artifacts to a depth of ca. $90 \mathrm{~cm}$ bs (Figure 1-11). Beyond this depth, only a canine jawbone was located at $147 \mathrm{~cm}$ bs. It is presumed that these remains date to Paleoindian times, or at least to the pre-contact period, based on the lack of Colonial period remains beyond a depth of $90 \mathrm{~cm}$ bs.
\end{abstract}

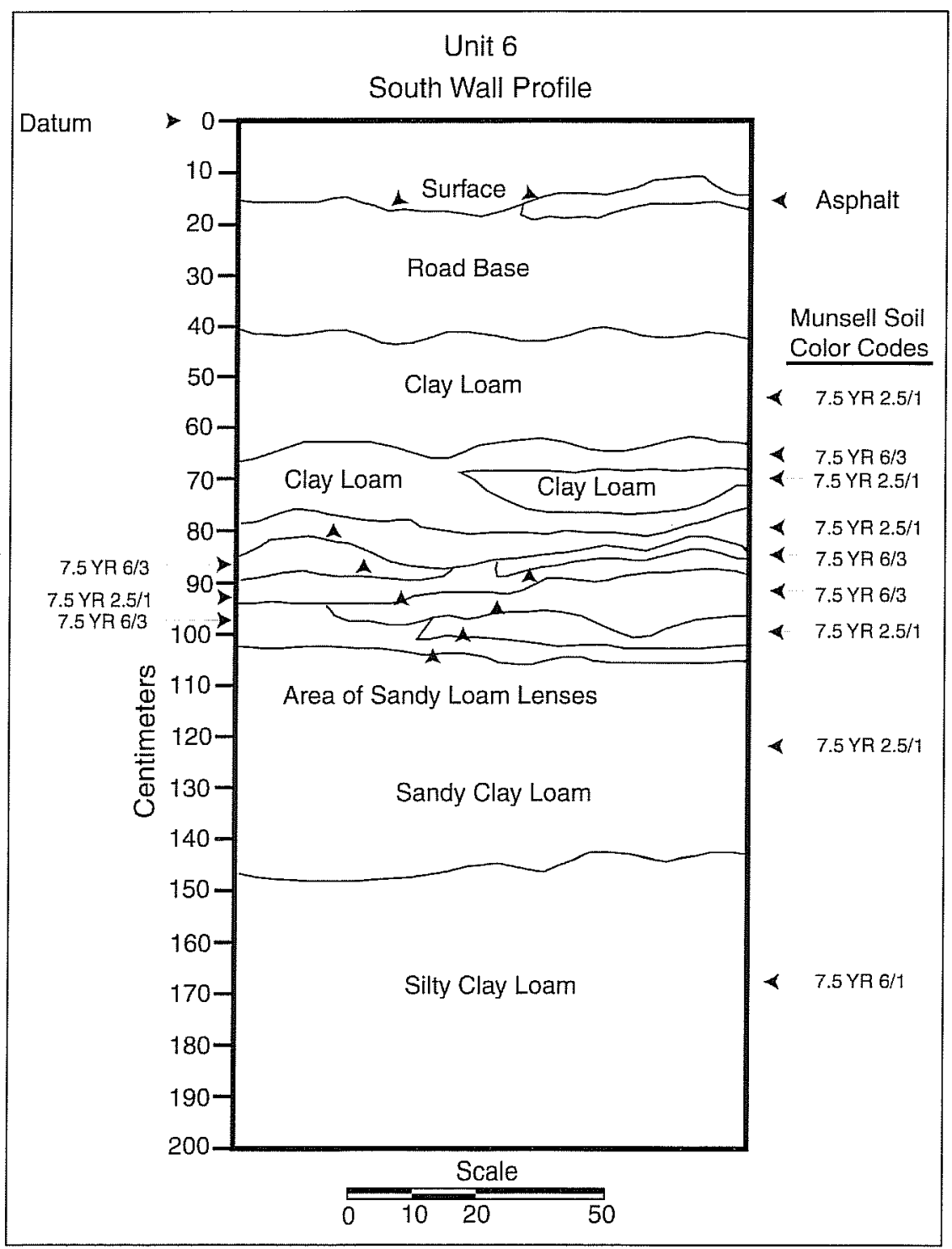

Figure 1-11. South wall profile of Unit 6. 


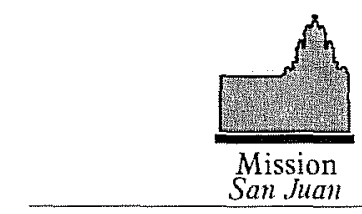

Trenching Route:

Units 7 and 8

Unit 7 was excavated at the edge of the parking area where a new telephone pole was to be placed (Figure $1-6)$. This area is only $2 \mathrm{~m}$ from the drop-off to the floodplain of the San Antonio River. This unit contained modern materials throughout and probably represents landfill activities dating to modern times.

Unit 8 was located along the proposed utility trenching line and was excavated to explore positive results from ST 4, which encountered a wall foundation (Figure 1-6). The wall exposed by ST 4 was further exposed in Unit 8, and it is a section of wall foundation related to a Historic period structure of unknown function. The cement, used to bind the limestone foundation stones, is finely textured and appears to date to the 1900s. This feature extends down ca. $40 \mathrm{~cm}$ bs at which point it comes into contact with a layer of bone (primarily bovine). In Level 6, at a depth of between $56-60 \mathrm{~cm}$ bs the intersection of two Colonial period wall foundations was encountered. A well-packed earthen floor with a layer of sub-floor fill was also found in association with these wall foundations. Directly beneath the sub-floor fill, sterile soil was encountered. 


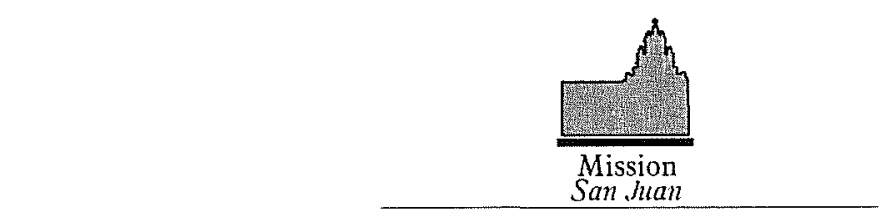

\section{Artifact Analysis}

\section{Ceramics}

Ceramics represent some of the most dependable artifactual materials for dating archaeological assemblages. The style and technique of manufacture changed regularly throughout the eighteenth and nineteenth centuries. A total of 763 ceramic sherds was recovered during this project (Table 1-1). They have been used for dating deposits and for determining the amount of disturbance present in various testing units.

\section{Unglazed Wares}

Unglazed wares found on Colonial sites in and around San Antonio tend to fall into two basic groups. A handbuilt, bone-tempered type commonly called Goliad ware was fired over an open fire (Figure 1-12a). This resulted in a dark gray to black core and surface colors ranging from tan to red. This type dominates most Spanish mission ceramic collections, and is probably a direct descendent of South Texas Prehistoric ceramic traditions (Fox et al. 1976:67). There were 309 sherds of this type recovered.

In contrast to these native-made unglazed sherds, one modern unglazed flower-pot sherd was also recovered. It was in the top level $(40-50 \mathrm{~cm})$ of Unit 7 along with two of the unglazed native sherds.

Table 1-1. San Juan, Ceramics by categories

\begin{tabular}{|l|c|}
\hline Ceramic Artifacts & Totals \\
\hline Burnished Wares & 8 \\
\hline Lead-Glazed Wares & 83 \\
\hline Porcelain & 4 \\
\hline Stoneware & 11 \\
\hline Tin-Glazed Wares & 50 \\
\hline Unglazed Wares & 326 \\
\hline British Ceramics & 281 \\
\hline \multicolumn{2}{|c|}{ Total Ceramics } \\
\hline
\end{tabular}

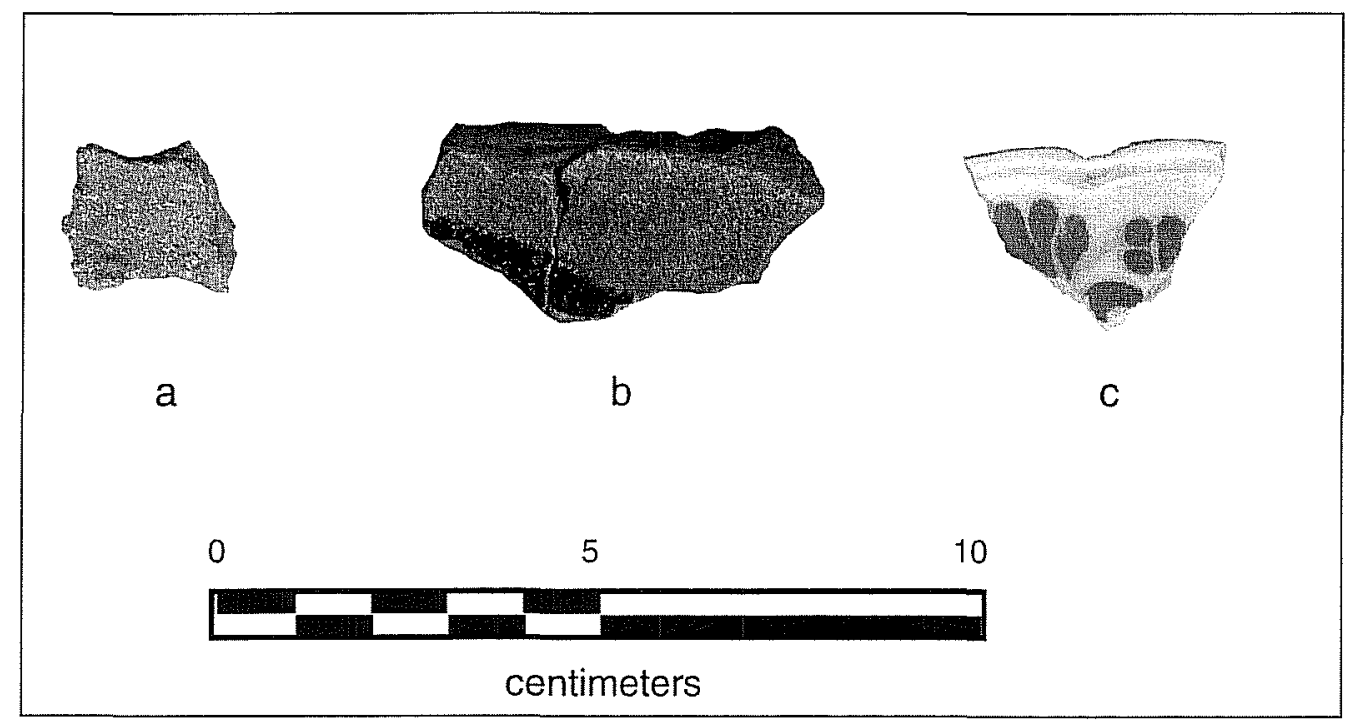

Figure 1-12. Ceramics: a) Goliad ware; b) Sandy Paste Lead-glaze ware; c) Majolica. 


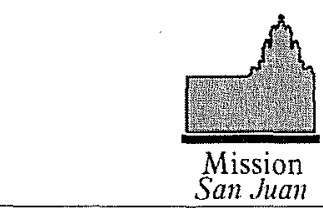

Another unglazed ceramic type, locally termed Valero ware, shows evidence of being made on a potter's wheel, and fired under more controlled conditions which result in the sherds showing the same reddish tan color throughout. Vessels represented are generally large jars, often bearing red-brown painted designs, and were probably made in Mexico. Their size and relative wall thinness suggests that they were meant for water storage. Only two sherds of this type were recovered in these excavations.

Fourteen other sherds are included in the unglazed category $(n=326)$, these are a red brown-bodied ware, recovered from ST 9 represent an unusual type of large, heavy, hand-built vessel not seen before at Mission San Juan, although sherds of a similar type came from the bottom of a bone deposit outside the west wall of Mission Valero (the Alamo). The sherds are red brown throughout, indicating some form of controlled firing and the possibility that they are of Mexican rather than local origin. Despite their even firing, the sherds are very fragile and tend to crumble during excavation.

\section{Burnished Wares}

These wares represent a continuation of preColumbian ceramic traditions in some areas of Mexico (Ivey and Fox 1999:31,34). Two types are commonly found on eighteenth century Colonial sites in Texas.

A burnished red ware probably from Central Mexico has designs created by burnishing into a matte surface. The vessels are primarily small bowls with curved-in rims and heavy bases. The burnished surfaces tend to spall occasionally which creates a speckled effect. One sherd of this type came from Level 3 of Unit 9.

The town of Tonalá, Jalisco, has a tradition of manufacturing ceramics with gray, red, and black slipped and burnished designs on a fragrant gray paste
(Charlton and Katz 1979). Seven sherds of Tonalá burnished ware were recovered during this project.

\section{Lead-Glazed Wares}

Large earthenware jars called botijas or Olive Jars (Goggin 1964:254) were used for shipping and storage on the Spanish frontier and were occasionally brought to Texas. Sherds of these vessels often bear a green lead-glaze on the interior and a dull white slip on the exterior. The sherds are consistently thicker than those of other ceramics generally present on Texas sites, averaging about $10 \mathrm{~mm}$ or more in thickness. Three olive jar sherds are in this collection.

The category with the largest representation of leadglazed sherds (60) is made up of pieces with a sandy paste with a few red brown inclusions (Figure 1-12b). The color of the glaze generally appears yellow, but is actually the result of a clear to very pale green lead glaze overlying a pinkish tan body. When the paste is gray to dark gray, the glaze appears green. The yellow sherds occasionally bear a green band parallel to or over the rim.

Lead-glazed sherds with a fine-textured, red brown paste decorated with linear and floral designs in dark brown, green, and cream on the necks of pitcher-like vessels and the outside of bean pots are called Galera ware across the southwest to California. Schuetz (1969:50) called this type West Mexico Polychrome and suggested that it was made in Jalisco. Barnes (1980:96) states that western Mexican goods were brought into competition with central Mexican goods during the reign of King Carlos III (1759-1788) when trading policies were liberalized, and that this type of pottery appeared on the frontier after 1750 . His latter statement has generally proven true at the San Antonio missions. Sixteen Galera sherds were recovered during this project. Today, similar ware is still being manufactured in Mexico. 


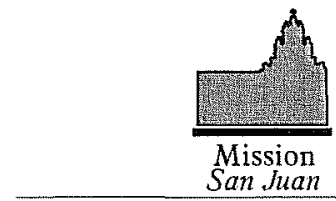

Three sherds with a red brown glaze over a finetextured red paste are similar to a type found by Schuetz during her excavations at San Juan. She termed this type Guadalajara ware (Schuetz 1969:51), suggesting that it came from that part of Mexico. The use of this term has been discontinued because of possible confusion with the earlier use of this same term (Deagan 1987:44-46) for what is now called Tonala Burnished Ware. Currently, this ceramic type is called Red-Brown ware (Fox 1974:59).

One sherd with a black luster glaze on a buff-colored paste from Unit 9 is included in this category. Schuetz (1969:52) has stated that this type originated in Santa Fe, Michoacan. Several similar sherds were recovered during her previous excavations at Mission San Juan.

\section{Tin-Glazed Wares}

Tin-glazed ceramics are earthenwares covered with a lead glaze to which tin has been added to create a white background for colored decoration. The decorative designs changed through time, making this type of ceramic useful for dating archaeological deposits. However, the sherds recovered during these excavations are so fragmented that in many cases only very basic typology, based mainly on the color of the decoration, is possible. Unfortunately, for this reason, the tin-glazed sherds recovered during this project are not helpful in dating.

Eighteen undecorated tin-glazed sherds were recovered. Although plain white majolica was occasionally made, most, if not all, of these sherds came from plain areas of otherwise decorated vessels.

All 23 blue-on-white sherds are too small to identify as to design, but each has some blue on white background. Two sherds have decoration in two shades of blue on white with a raised, undulating rim. The pattern resembles that of San Agustín majolica, but there is no evidence of the blue looped design customarily found on the reverse side of this type (Figure 1-12c) (Goggin 1968:189).
Four sherds with a tin-glazed design called Huejotzingo have merely a single band of color at and over the rim. Of these, three have a blue band and one has a yellow band. This type was made throughout the eighteenth century (Goggin 1968:195) and is, therefore, not useful for precise dating.

Three sherds of the San Elizario type date from 1750 to 1800 (Gerald 1968:45). They are identified by black/ brown accents on blue portions of decorative designs.

Sherds from two majolica bowls or cups, decorated with thin blue bands and blue dots are of the Puebla Blue on White II type (Seifert 1977:186) and are dated to the late-eighteenth century.

\section{British Ceramics}

White bodied earthenwares began to appear in the San Antonio area in the early $1830 \mathrm{~s}$. Their presence is generally an indication of nineteenth century occupation of a site. British-made sherds $(n=281)$ were also recovered during this project. Plain white sherds within early 1800 s occupation levels generally represent undecorated portions of otherwise decorated wares. Decorations on whiteware can take many forms. They consist of bright primary colors applied in various ways to a white body, and include transfer printing, hand-painted floral designs, spatter or sponged decoration, painted rims over molded designs, and alternating bands of slip-painted colors (Figure 1-13a, b, c, d).

\section{Copper Luster}

Two sherds, included under this category due to their British origin, actually have a red paste with a copper luster glaze. They are recorded here because they represent approximately the same time period as the whitewares (Godden 1975:215). 


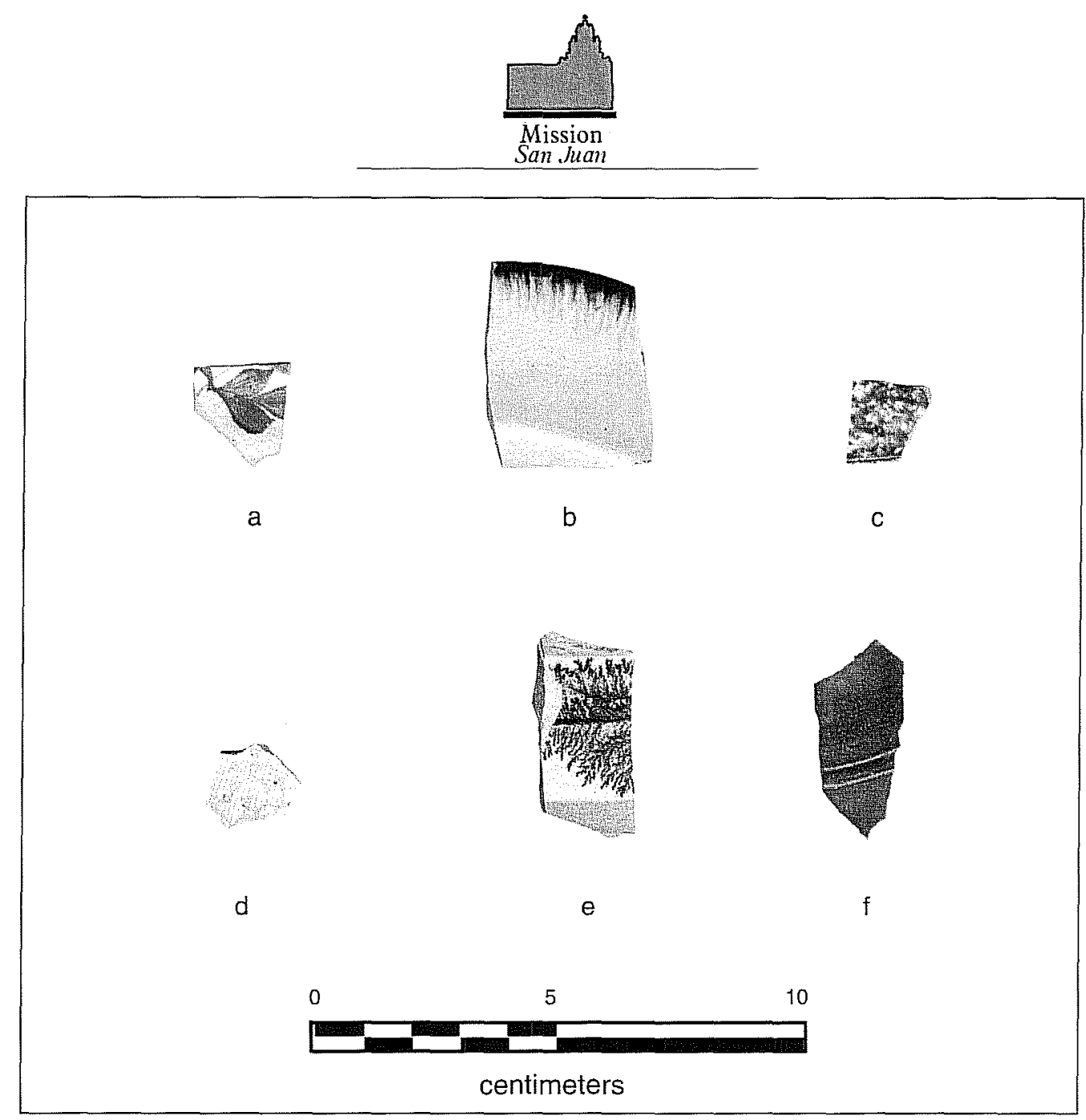

Figure 1-13. Nineteenth Century Ceramics: a) Handpainted Whiteware; b) Shell Edged Whiteware; c) Sponged Whiteware; d) Transfer Decorated Whiteware; e) Yellowware;

f) Stoneware Ink Bottle.

\section{Yellowware}

In the late-nineteenth and early-twentieth century this type of ceramic was popular as utility ware in the kitchen. First made in England, by the mid-nineteenth century British yellowware potters moved to the East Coast of the United States and on into Ohio where yellow clays were readily available (McAllister and Michel 1993:14). One sherd of yellowware was recovered from Unit 5 along with numerous sherds of British whitewares, suggesting that this piece may have come from England (Figure 1-13e).

\section{European Porcelain}

Porcelain is a white, vitrified, translucent ceramic ware. The four porcelain sherds in this collection were probably made in England or Europe. Porcelain was first made commercially in Germany in 1710 (Atterbury 1979:59), it does not appear in San Antonio sites until well after 1800. Families usually had a few special pieces such as cups, saucers, and dessert plates kept for company use, since porcelain was the most expensive ware available at that time (Miller 1980:4). 


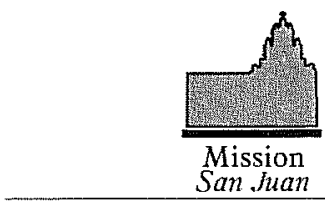

\section{Stoneware}

Eleven sherds of stoneware are in this collection. Two are from ceramic bottles, which contained ink, and one is from a bottle that may have contained gin or mineral water (Figure 1-13f). The remainder in the collection represent various forms of utility-ware such as milk pans, crocks, and jars for preparing and storing food. Surfaces have primarily a salt glaze or Albany slip or a combination of the two, which were commonly used on stoneware found in mid-to-latenineteenth century sites in this area. The only exceptions are a handle segment from Unit 1 and a sherd from Unit 5 which bear a yellow green Leon slip glaze used by the Meyer family in Atascosa from 1895 until the 1920s (Greer and Black 1971).

\section{Non-Native-Made Ceramics}

The list of non-native-made ceramic types recovered during these excavations is identical to those recovered from recent excavations at Mission Rosario (Nickels 2000) and Mission Refugio (Tennis 2001). However, in comparing the recovered collections there are interesting differences in the percentages of each type (Table 1-2).

A number of factors influence the relative frequencies of non-native ceramics on mission sites. The dates of occupation limit the variety as well as the percent- ages of various types. A limiting factor is also the date at which a ceramic type became available on the frontier, which is not necessarily the date at which it was first manufactured. On mission sites in the San Antonio River Valley, a great deal depended upon the choices made by the procurator whose job it was to purchase the supplies for the annual mule train that went to the San Antonio missions and later through Goliad to Mission Refugio.

In the Mission San Juan collection, the highest percentage consists of British-made white bodied wares, while the Mexican lead-glazed and tin-glazed wares are obviously less frequent. In contrast, the percentages are quite different at Rosario (1754-1807) and Refugio (1795-1830) for the percentages are quite the reverse. Since Mission San Juan continued to be occupied into the late nineteenth century, it is not surprising to find British-made whitewares on this site. However, examination of the field forms indicates that these wares were limited primarily to excavations north of the church. Units $1,2,3,9$ and 10 in the area where the buried walls were found contained very few whitewares, with none appearing below the fourth level, probably ruling out a post-1800 date for construction of these foundations. The presence of most of the post-colonial ceramics in the area behind the residential buildings reflects the fact that these building were occupied well into the nineteenth century (Schuetz 1968:66).

Table 1-2. A comparison of Non-Native-Made Ceramic Types from three Texas Missions

\begin{tabular}{|l|c|c|c|}
\hline Ceramic Types & $\begin{array}{c}\text { Mission } \\
\text { San Juan }\end{array}$ & $\begin{array}{c}\text { Mission } \\
\text { Rosario }\end{array}$ & $\begin{array}{c}\text { Mission } \\
\text { Refugio }\end{array}$ \\
\hline Burnished & $8(1 \%)$ & $15(8 \%)$ & $62(3 \%)$ \\
\hline Lead-Glazed & $83(19 \%)$ & $97(51 \%)$ & $734(34 \%)$ \\
\hline Tin-Glazed & $50(12 \%)$ & $74(39 \%)$ & $722(34 \%)$ \\
\hline British & $281(65 \%)$ & $1(.5 \%)$ & $599(28 \%)$ \\
\hline Porcelain & $4(.9 \%)$ & $4(2 \%)$ & $3(.1 \%)$ \\
\hline Stoneware & $11(2 \%)$ & $0(0)$ & $24(1 \%)$ \\
\hline \multicolumn{4}{|c|}{} \\
\hline TOTAL & $\mathbf{4 3 7}$ & $\mathbf{1 9 1}$ & $\mathbf{2 1 4 4}$ \\
\hline
\end{tabular}




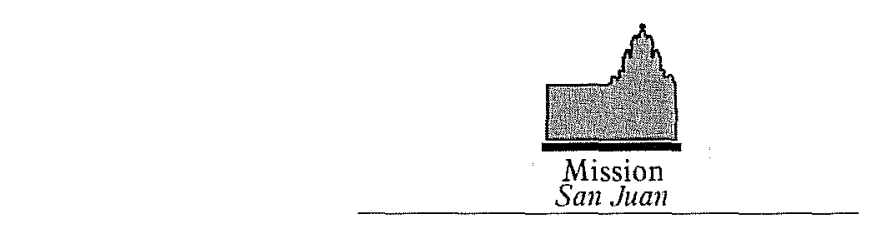

\section{Glass Containers}

A total of 476 sherds from glass containers are in this collection. Of these, 14 represent black glass bottles (actually very dark green) which were common until the 1860 s but had gone out of use by the $1880 \mathrm{~s}$ (Kendrick 1967:22). Brown glass, of which there are 72 fragments, usually represents bottles containing alcoholic beverages. Clear glass ( 288 sherds) was by far the most common type found. Included among the clear glass are a few fragments of pale aqua glass which generally represent early (pre-1840) glass made before it became fashionable to bleach glass containers with various chemicals to make them appear clear.

The fact that few if any glass sherds are sun-colored purple or amber (a product of bleaching chemicals when they are exposed to the sunlight for a time) suggests that most of these deposits were rapidly covered with soil or arrived on the site after the 1930s.

Green glass sherds $(n=99)$ appear to represent wine bottles, which are commonly found on San Antonio sites from the eighteenth through the twentieth century. Except for differences in patination, described below, they are not useful for dating or identifying occupations.

Red glass (two sherds) and white or milk glass (one sherd) seem to appear on San Antonio sites after 1900. Red glass is created by the addition of copper or gold to the mix (Kendrick 1967:55), and milk glass is made with the addition of tin or zinc (Munsey 1970:37).

Nearly all the glass fragments are too small to allow observations on their manufacture or contents. There are two exceptions: 1) A whole, slim clear glass bottle from Unit 7, Level 6 (Figure 1-14), embossed "PURE OLIVE OIL DE UMBERTO", has a mold seam through the lip suggesting a date after 1900 (Kendrick 1966:48); and 2) Five olive green sherds from ST 5, Level 1 bear a thick, gold-colored patina typical of that found on Spanish Colonial period wine bottles in other parts of Texas (Fox, Day, and Highley 1980:88).

\footnotetext{
from Unit 7, Level 6.
} 


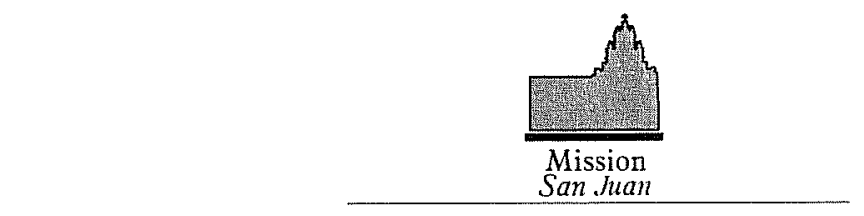

\section{Metal Fragments}

In all, 433 fragments of metal were recovered. Of these, eight were copper alloy, which is so frequently found on Spanish Colonial sites that it has become a time marker for Colonial deposits. Thin, rusted iron fragments, of which 425 were found, are commonly present in post- 1800 contexts. Much of this material may represent the early nineteenth century replacement of the original thatched roofs with roofing tin during the Republic period (Schuetz 1969:34). In deposits from the last half of the nineteenth century into the twentieth century most thin metal scrap represents tin cans. Their use began in the $1840 \mathrm{~s}$ (Vaughan 1997:209) and continues to the present day.

\section{Metal Fragments - Household}

Among the metal scrap recovered, a few objects can be identified:

a) A flat, pierced circle of thin metal, $28 \mathrm{~mm}$ in diameter from Unit 2, Levels 1-2, is the metal base for a votive candle. A projection in the center was used to hold the bottom end of the wick during manufacture of the candle. Present-day candles are often similarly made.

b) The center section of a knife blade came from Level 2 of Unit 9. The width and thinness of the blade suggest it came from a kitchen knife or table knife, rather than one for outdoor or hunting use.

c) A thin, delicately shaped handle from Level 5 of Unit 8 probably represents a teaspoon. Although its size and proportions suggest it, there is no evidence of silver or silver plating on this object.

d) Two fragments of heavy cast-iron found in Level 4 of Unit 8 are segments of the wall and one leg from a three-legged cooking pot. These pots, designed for use in the fireplace or over an open fire, were used during the eighteenth and earlynineteenth centuries throughout the frontier. e) Level 2 of Unit 4 contained a hand-forged fragment of a machine or wagon part of uncertain age and use. The crudeness of the hole punched into it and the fact that it is forged suggest it may date to the last half of the nineteenth century.

\section{Arms}

Two .22-caliber short cartridge shells were found in Level 4 of Unit 1 . They are both "rim fire" cartridge shells with a manufacturer's head-stamp of "Super$X^{\prime}$, indicating the Western Cartridge Co. Cartridge shells of this caliber are the most common of all American cartridges. First appearing in the United States around 1857 (Logan 1959:63), they have remained in heavy use through to the present time.

\section{Miscellaneous Artifacts}

\section{Beads}

One blue glass trade bead was recovered. Harris (Harris and Harris 1967) includes this in his Type 48, which he describes as a "small, dark Bluebird Blue, translucent, donut-shaped garter bead of simple construction." The same type was found on the Womack Site (Harris et al. 1965:287-363), the Gilbert Site (Davis et al. 1967:97), and at San Juan in 1967 (Schuetz 1969:59).

\section{Buttons}

A five-hole bone button with depressed center section came from Unit 8, Level 4. Such buttons were used on underwear and trousers from the early eighteenth to the early-nineteenth century. A metal button (probably brass) with a flat face and a drilled shank dates from the eighteenth to the early-nineteenth century. Identical buttons have been found on most of the mission sites in San Antonio. This one was recovered from Unit 3, Level 2. 


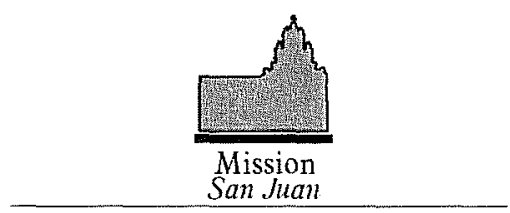

A four-hole molded metal button (mold seam across the center) came from Level 2 of Unit 4 . Another fourhole metal button, recovered from Level 2 of Unit 1, has a depressed center and an iron back with a decorative rim around the face. These buttons were commonly used on work clothes in the latenineteenth century.

One white porcelain button with four holes found in Level 3, Unit 10 can be dated to ca. 1850 to 1900 (Meissner 1997:120). A larger four-hole, white glass button with an impressed design came from Unit 5 , Level 1. This button, also, dates to between 1850 and 1900 .

\section{Marbles}

An unglazed, handmade, clay marble was found in Unit 4, Level 2. Schuetz found 71 marbles of this type during her excavations at Mission San Juan (1969:38). Clay marbles were commonly produced by American potters beginning around the time of the Civil War and were produced either by hand or by machine until the 1920s (Zapata 1997:108).

\section{Coin}

A United States, Lincoln penny dated 1964 came from Unit 7, Level 1.

\section{Tin Foil}

Three fragments of tin foil were found at various levels in Unit 9 and Shovel Tests 4 and 8.

\section{Unidentified Object}

An unidentified object from Unit 7, Level 6 consisted of a small metal loop from which two strings protruded. Another piece of string was found in Unit 8, Level 1.

\section{Fabric}

A small piece of knitted fabric resembling part of a woman's stocking, made with very fine medium brown thread, came from the 5th level of Unit 1 . The presence of this fragment at such a deep level strongly suggests disturbance in this unit.

\section{Peach Pit}

A small peach pit was excavated from the 17 th level of Unit 4. Peaches were cultivated at many of the missions during the eighteenth century.

\section{Ocher}

Fragments of yellow and red ocher came from five different units at various levels. Ocher is common in the soils of this area of South Bexar County, and may well have been used for various purposes by the Native inhabitants of the mission.

\section{Construction}

\section{Nails}

The nails recovered during this project are cut or square nails, which date to the nineteenth century, and wire nails, which generally date in Texas from ca. 1900 to the present. Of the 123 cut nails, the only concentration came from Unit 5 where 44 were found between $20-50 \mathrm{~cm}$ bs. The 105 wire nails recovered were not found in any particular concentration but were scattered over the entire area. Disturbed deposits are implied whenever wire nails, with their relatively late date of manufacture, are found at deep levels.

In addition to the nails, two heavy spikes were recovered. A railroad spike from Level 3 of Unit 5, ca. six inches long, has the typical offset head and chisel point usually found on such objects. A smaller, squareheaded spike, which is $1 / 4$-inch square, came from Level 1 of Unit 8. 


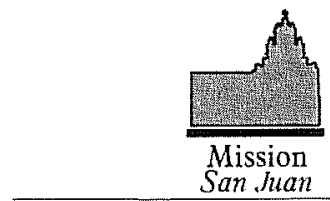

Two short, cut-off sections of steel reinforcing rods were recovered. One from Level 1 of Unit 4 is 3/4inch in diameter and one from Level 1 of Unit 8 is cut from a half-inch rod. These would be the products of relatively recent construction in the area.

The only other identifiable metal object, which can be related to construction activities, is an iron pintle from a strap hinge. This pintle is of the Spanish type called a drive pintle, because it is intended to be driven into a doorjamb. It is made by bending a piece of square stock at a right angle, rounding the vertical pin so it would slip smoothly into the barrel of a strap, and tapering the spike to a point (Simmons and Turley 1980:136-138).

\section{Brick}

The 68 brick fragments recovered were scattered throughout the area. They varied from the thin, $\tan$ to red brown mission-made bricks or ladrillos present on all San Antonio mission sites to the late-nineteenthcentury yellow, tan, and red bricks found commonly on downtown San Antonio sites. The latter began to arrive in increasing quantities after the railroads arrived in San Antonio in the 1870s. Neither type was present in sufficient quantities to imply their use in nearby structures.

\section{Mortar}

While fragments of mortar were present in many areas, the main concentration appears to have been in Unit 5, between 50 to $90 \mathrm{~cm}$ bs. However, most of this mortar contains some modern cement, which rules out any possibility that this is an undisturbed location. The presence of decorated whitewares as deep as $50-60 \mathrm{~cm}$ bs in this unit tend to corroborate this conclusion. None of the mortar recovered can be confidently identified as dating to the eighteenth to latenineteenth century Colonial and Early-settlement periods before cement became available. Prior to that time, mortar consisted of sand and burned lime only.

\section{Tar Paper}

Fragments of felt, impregnated with tar or asphalt, probably represent late-nineteenth century or later roofing repairs. Most of these fragments came from Unit 7, where they were found as deep as $100 \mathrm{~cm}$ bs. Since this unit is located over the edge of the drop-off toward the river, where trash has been traditionally dumped, this is not unusual. Judging from the ceramics recovered from this unit, the deposits are thoroughly mixed.

\section{Plastic}

Various types of plastic were recovered from the upper levels of many of the test units. These included fragments of present-day drinking straws, plastic bags, and earlier forms of man-made materials such as Bakelite. Not surprisingly, most of the plastic items were recovered from Unit 7, which included 9 Bakelite fragments and several plastic bags. 


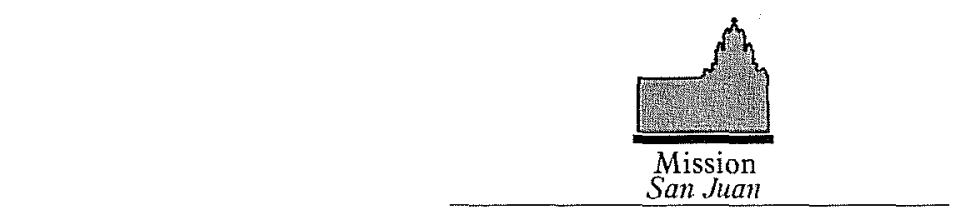

\section{Lithic Artifact Analysis}

\author{
by Steve A. Tomka
}

A total of 210 chipped lithic artifacts were recovered during this project (Table 1-3). They are categorized into two functional groups: projectile points and scrapers. The use of the artifacts classified as scrapers was determined by low-powered ( $80 \mathrm{x}$ ) micro-wear analysis. Three unifacially flaked artifacts could not be grouped into functional categories. They are classified as indeterminate unifaces. A single core was also recovered, in addition to 196 pieces of unmodified lithic debitage. With the exception of a medial arrow point fragment, all remaining artifacts are of fine-grained chert.

\section{Projectile Points}

A total of six projectile points and fragments were identified in the collection (Table 1-3). Two are complete, three are medial fragments, and one is a distal specimen. Four of the six are arrow points; the remaining specimens may represent dart point fragments.

\section{Arrow Points}

The two complete arrow point specimens, recovered from Unit 9, are classified as Guerrero points (Figure 1-15). These points are commonly associated with mission occupations (Turner and Hester 1993). The specimens are characterized by triangular to lanceolate outlines and straight to slightly concave bases. The point from Level 8 (Figure $1-15 a$ ) is more finely chipped and thin while the one from Level 2 is thicker, more roughly flaked, and has one beveled edge (Figure 1-15b). Given the difference in workmanship and thickness, it is possible that this second point is reworked from a late-Prehistoric or, even an Archaic artifact. The original ventral surface of the flake blank could be identified on one of the two; the other is fully bifacially flaked. Both specimens exhibit blade rejuvenation.
The cause of the break in the point fragment from Level 4 of Unit 8 cannot be determined with certainty, although the workmanship of the small fragment suggests it is an unfinished specimen. The medial fragment of the arrow point made from green Colonial glass found in Level 3 of Unit 2 was clearly broken in manufacture. Neither of the two fragments is assigned to the Guerrero type although they most likely represent failed Guerrero blanks.

\section{Possible Dart Point Fragments}

Two untyped medial fragments from projectile points may represent dart points. One of the two (Figure 1$15 \mathrm{c}$ ), is a very broad ( $45 \mathrm{~mm}$ ), strongly shouldered specimen with a contracting stem. The base of the point is broken. The cause of the break cannot be determined with certainty. Although the shape of the base cannot be determined, if it was straight the point would be assigned to the Langtry type. In its present condition, the specimen may represent a recycled dart point, a stemmed knife, or a very large arrow point blank. No use or haft wear was noted under low-powered magnification analysis.

The second medial fragment, from Level 14 of Unit 4 , is relatively short but thick $(4.5 \mathrm{~mm}$; Table $1-3)$. It is this thickness that is more reminiscent of dart rather than arrow points. However, the fact that the specimen was broken in manufacture may also indicate that it is a discarded arrow point blank.

\section{Scrapers}

A total of four artifacts were identified as scrapers (Table 1-3). Based on the location of the working edge -two are classified as end scrapers while the other two are side scrapers. From the degree of retouch on their working edges, one of the end scrapers is a heavily reworked formal end scraper while one of the side scrapers is a minimally retouched spoke shave. The remaining specimens, an end and a side scraper, are expedient tools, not retouched, either before or 


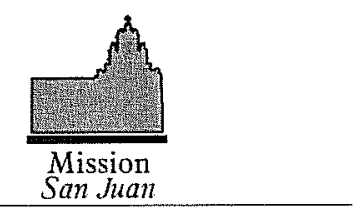

Table 1-3. Lithic artifacts recovered from San Juan by categories

\begin{tabular}{|c|c|c|c|c|c|c|}
\hline UNIT & LEVEL & TOOL TYPE & Max. Length & Max. Width & Max. Thickness & Comments \\
\hline & & Arrow Points & $(\mathrm{mm})$ & $(\mathrm{mm})$ & $(\mathrm{mm})$ & \\
\hline 9 & 8 & Guerrero Arrow Point & 24 & 13 & 3 & Flake \\
\hline 9 & 2 & Guerrero Arrow Point & 27 & 16 & 5 & Poss. Recycled Archaic point \\
\hline 8 & 4 & Arrow Point Distal Frag. & & & 2.5 & Indeterminate \\
\hline \multirow[t]{3}{*}{2} & 3 & Arrow Point Medial Frag. & & & 3 & Made on a piece of green colonial glass \\
\hline & & & & & & \\
\hline & & Possible Dart Points & & & & \\
\hline 7 & 3 & Projectile Point Medial Frag. & & 45 & 4 & Indeterminate; see Figure 15-c. \\
\hline \multirow[t]{3}{*}{4} & 14 & Projectile Point Medial Frag. & & & 4.5 & Indeterminate; Manufacture failure \\
\hline & & & & & & \\
\hline & & Scrapers & & & & \\
\hline 2 & $1-2$ & Heavily Reworked Formal End Scr. & 27 & 30 & 9 & Tertiary Blade-like Flake \\
\hline 2 & $1-2$ & Minimally Retouched Spoke Shave & 50 & 30 & 10 & Secondary Blade \\
\hline 2 & $1-2$ & Expedient Side Scraper & 28 & 26 & 9 & Secondary Flake \\
\hline \multirow[t]{3}{*}{5} & 10 & Expedient End Scraper Distal Frag. & & 28 & 10 & Secondary Blade Frag. \\
\hline & & & & & & \\
\hline & & Indeterminate Unifaces & & & & \\
\hline $6 \mathrm{~A}$ & 1 & Indeterminate Uniface Edge Frag. & & & 12 & Prob. Made on Blade \\
\hline 7 & 2. & Indeterminate Uniface Edge Frag. & & & 7 & Made on Secondary Flk. \\
\hline \multirow[t]{3}{*}{1} & 4 & Indeterminate Uniface Edge Frag. & & & 4 & Prob. Made on Blade \\
\hline & & & & & & \\
\hline & & Core & & & & \\
\hline 9 & 2 & Pebble Core Frag. & 74 & 63 & 31 & Corticate Chert Pebble \\
\hline
\end{tabular}

after use. The spoke shave and the two end scrapers are made on secondary (2) and tertiary (1) blades or blade-like flakes. The remaining expedient side scraper is made on a secondary flake.

\section{Indeterminate Unifaces}

Three unifacially retouched flake fragments are included in this category (Table 1-3). These represent items that could not be classified into functional tool categories due to their fragmented nature or lack of use-wear. With the exception of thickness, no other dimensions were recorded on these specimens.

\section{Core}

One multi-directional core fragment was recovered from Level 2 of Unit 9 (Table 1-3). It exhibits flake removals from four directions and probably represents a fragment of a larger multi-directional core. It has nine flake removals and still retains cortex over approximately $15-20$ percent of its surface.

\section{Unmodified Debitage}

A total of 196 unmodified debitage was recovered during excavation. The breakdown of cortex categories among these specimens indicates that tertiary flakes dominate (Figure 1-16). Primary flakes represent a small portion of the collection. In general, these patterns suggest that more than the initial reduction of cobbles took place at the mission. It seems, although raw materials may have been introduced as corticate nodules, they were substantially reduced once at the mission. This pattern contrasts with that noted at Mission San José, where the percentage of primary and secondary flakes was about the same as the percentage of tertiary flakes (Tomka and Fox 1998:31). 


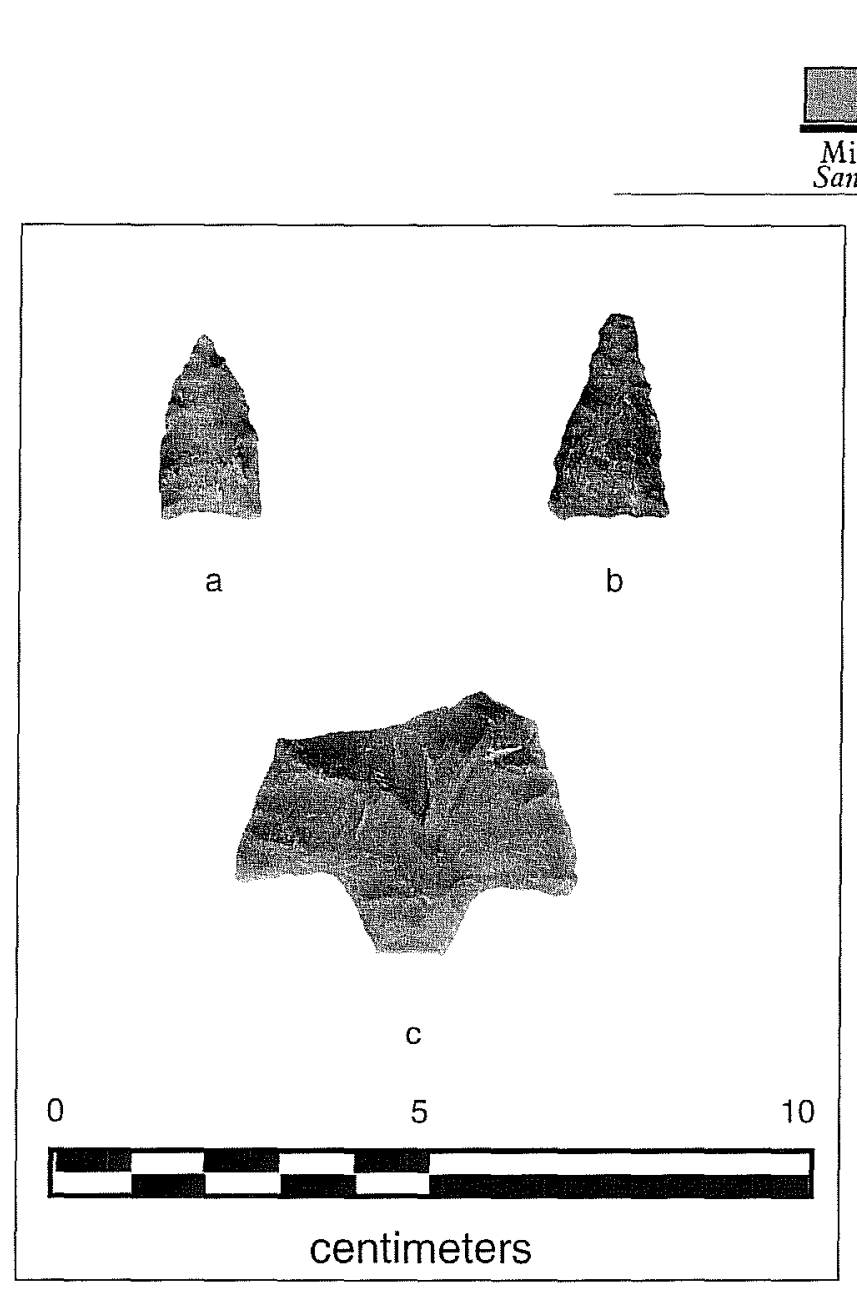

Figure 1-15. Lithic artifacts recovered from Mission San Juan: a-b) Guerrero Arrow Points; c) Possible Dart point fragment.
The distribution of debitage by size classes indicates that 11-20 and 21-30 mm specimens dominate the collection (Figure 1-17). The smallest size class $1-10 \mathrm{~mm}$ ) may be under-represented primarily because of the 1/4-inch hardware cloth used in screening the bulk of the matrix. The size class distributions are similar to those from Mission San José (Tomka and Fox 1998), and indicate a gradual decrease in the percentage of specimens in the larger size classes.

The distribution of platform facet counts indicates that single faceted flakes are the most common among complete and proximal fragments of the platform-bearing specimens (Figure 1-18). Importantly, corticate platforms are the second most common type; further illustrating the relative scarcity of flakes with highly prepared platforms. Platform-bearing flakes with two, three, or more facets represent a relatively small proportion of the collection. This pattern stands in strong contrast to debitage collections dominated by bifacial reduction, where multi-faceted striking platforms greatly outnumber corticate and single faceted specimens (Tomka 1989).

The breakdown of the debitage collection in terms of flake type indicates that core/platform preparation flakes constitute the largest proportion of the sample (Figure 1-19). Thus, as mentioned, a large proportion of the platform-bearing flakes are single faceted or corticate, and many of the specimens have blade-like morphologies, it is likely that most of these flakes derive from the preparation of unior multi-directional cores rather than bifacial core reductions (e.g., the manufacture of bifaces). Blades constitute the second largest percentage of the debitage, excluding indeterminate flakes and angular debris. Flakes identified as the products of other reduction strategies (e.g., biface manufacture, thinning, and uniface manufacture and resharpening), represent a very small proportion of the collection.

Figure 1-16. Debitage cortex categories from Mission San Juan. 


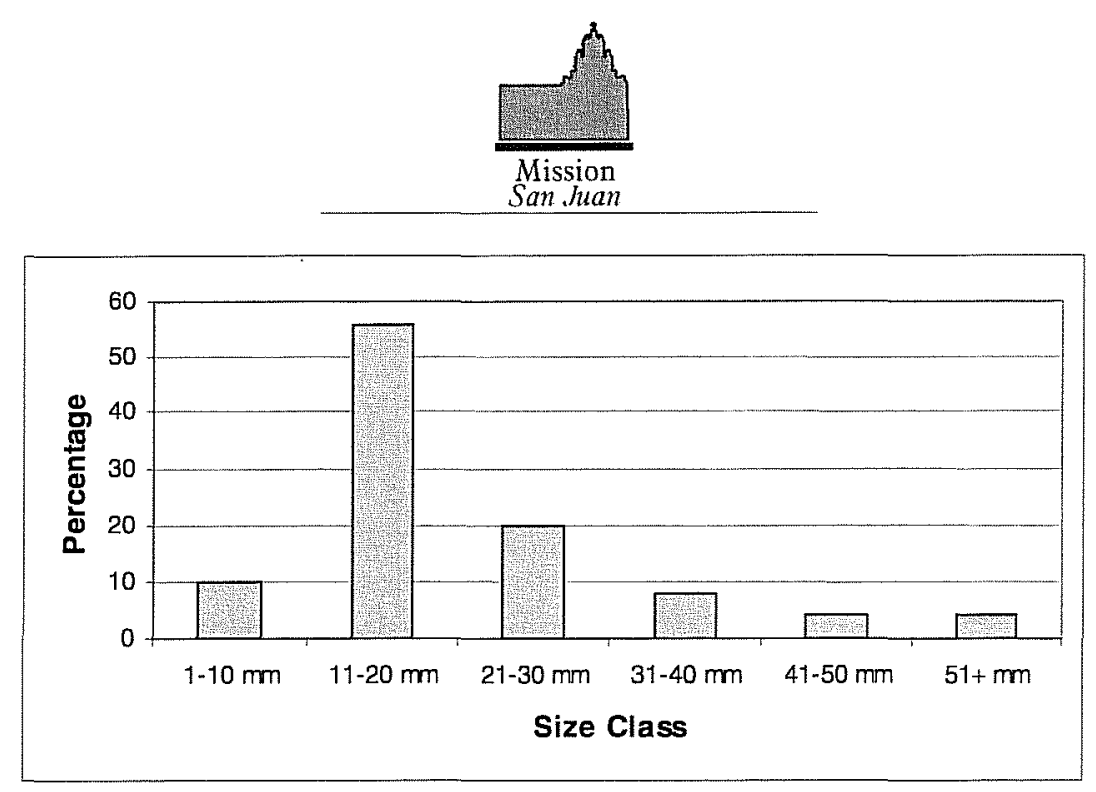

Figure 1-17. Debitage size class categories in $10 \mathrm{~mm}$ increments from Mission San Juan.

The scarcity of biface flakes corresponds to the relative emphasis on uni- and perhaps bi-directional blade production at the mission (Fox 1979:37; Hester 1977, 1989, 1998). If the small sample is an accurate reflection of the scarcity of bifacial tools, their absence contrasts with some mission assemblages that appear to contain the same range of tool forms as their Late Prehistoric antecedents. It is possible that the blades and flake blanks were used as expedient tools rather than being reduced into formal specimens.

Overall, the lithic technology evident in the small sample from San Juan reflects: the procurement of local or nearby raw materials, a tool kit composed primarily of expedient tool forms (e.g., scrapers), a heavy reliance on blade and/or flake blank production, and the continued manufacture of stone arrow points. Bifacial reduction appears to be employed in arrow point manufacture and the shaping of some gunflint blanks.

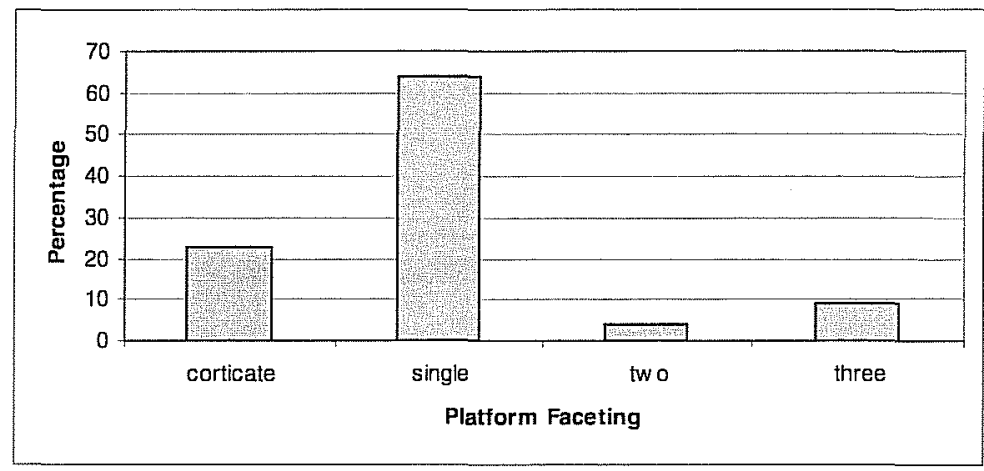

Figure 1-18. Platform faceting categories among platformbearing debitage, Mission San Juan.

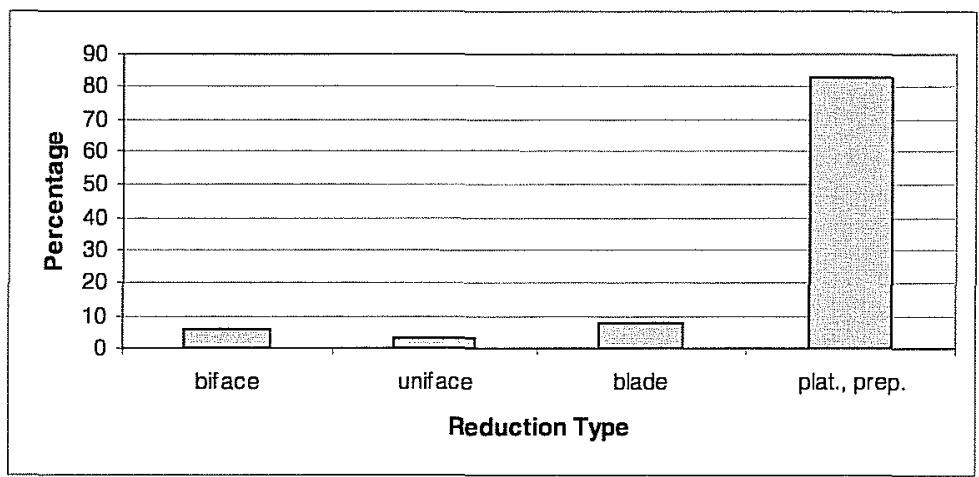

Figure 1-19. Lithic reduction types among classifiable debitage, Mission San Juan. 


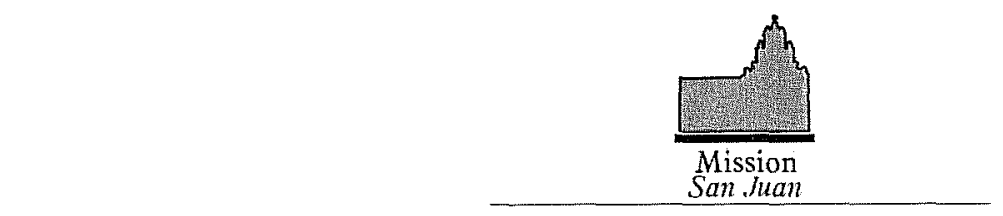

\section{Vertebrate Faunal Remains}

\author{
Barbara A. Meissner
}

\section{Methods}

A total of 12,775 vertebrate faunal remains, weighing $17,912.86 \mathrm{~g}$, was recovered during the course of the project. Of these, 12,537 were recovered in excavation test units (TUs) and 238 in shovel tests.

In the field, the bone was recovered by dry screening matrix through 1/4-inch mesh. Bones were bagged with other artifacts by unit and level.

In the laboratory, all bone was washed, dried, then bagged by unit and level. The bone was identified to the most specific taxon possible using the comparative collection at CAR, as well as several standard reference texts (Balkwill and Cumbaa 1992; Boessneck 1970; Gilbert 1990; Hildebrand 1955; Hillson 1986; Olsen 1960, 1964, 1968; Schmid 1972). Identifications made were conservative, i.e., bone which appeared to be cow-sized was not identified as Bos taurus unless it could be differentiated from Bison and Equus species. All bone recovered was weighed and evidence of exposure to heat was noted. Element, portion of element, side, and evidence of immaturity were noted on bone identified to the order taxonomic level. Evidence that bones had been gnawed was noted. When bone could be identified only as mammal, an estimate of the size of the animal was made when possible.

\section{Results}

\section{Faunal Remains - Test Units}

Bone from the test units is considered here. Bone from the shovel tests will be considered separately.
Most of this collection is highly fragmented. The average bone weight was only $.81 \mathrm{~g}$, however, this varies a great deal from unit to unit, as discussed below. Ninety-three percent of the bone could be identified only as mammalian. Only 425 bones ( 3.4 percent) could be identified to the genus taxonomic level. A list of identified taxa from the test units is shown in Table 1-4, with counts, weights, and notes.

\section{Number of Identified Specimens (NISP)}

The list of bone specimens identified to, at least the genus taxonomic level in the test units is listed in Table 1-5. Cottontail rabbit (Sylvilagus sp.) is the most commonly identified bone, constituting 22.8 percent of the total Number of Identified Specimens (NISP). Together with other wild mammals commonly hunted for food (e.g., deer, raccoon, and opossum), they represent 27.3 percent of the NISP. Cattle (Bos taurus) is the next most common, with 14.1 percent of the NISP. Other domestic animals such as goats, sheep, and pigs account for only 4.9 percent, while birds were 6.8 percent of the total, and identified fish were 5.6 percent. Identified turtle remains were 10.5 percent of the total NISP. These figures, however, give a false impression of the importance of species with smaller body weight. Bone weight is, in general, a better indicator of relative dietary importance (as opposed to relative abundance) than NISP, but this measure must be used with some caution. In general, larger bones carry more meat, but the relationship is not linear (Reitz and Scarry 1985:18), varies among different taxa, and there is considerable variation from one part of the animal to another (e.g., lower legs of cattle are dense, heavy bones but carry relatively little meat compared to other bones of the body) (Lyman 1994). Table 1-6, which shows the percentage of total NISP weight for each of the categories listed above, clearly demonstrates the dominance of cattle. 


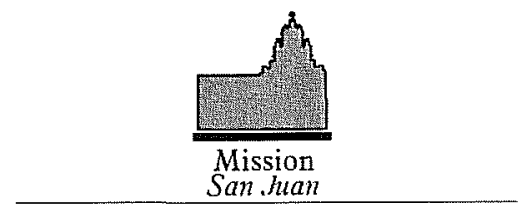

Table 1-4. San Juan, Identified taxa from test units (TUs 1-10)

\begin{tabular}{|c|c|c|c|}
\hline Taxa & Common Name & Count & Weight (g) \\
\hline Mammalia & Mammals & & \\
\hline Artiodactyl & Deer, sheep, goats & 68 & 234.21 \\
\hline Bos taurus & Cattle & 60 & $2,107.27$ \\
\hline Bovinae & Cattle or bison & 121 & $1,731.59$ \\
\hline Canis sp. & Dog, wolf, or coyote & 26 & 74.64 \\
\hline Canis latrans & Coyote & 1 & 47.46 \\
\hline Capra hircus & Domestic goat & 6 & 45.46 \\
\hline Capra /Ovis & Goat or sheep & 2 & 7.36 \\
\hline Chiropterae & Bats & 1 & 0.01 \\
\hline Didelphis virginianus & Opossum & 1 & 0.72 \\
\hline Equus sp. & Horse family & 1 & 10.69 \\
\hline Equus caballos & Horse & 3 & 20.51 \\
\hline Felis cf. domesticus & Domestic cat & 1 & 0.17 \\
\hline Lepus califormicus & Blacktailed jackrabbit & 1 & 0.34 \\
\hline Neotoma sp. & Woodrats & 14 & 3.41 \\
\hline Odocoileus virginianus & White-tailed deer & 16 & 89.81 \\
\hline Ovis aries & Domestic sheep & 7. & 62.03 \\
\hline Perognathus sp. & Pocket mice & 1 & 0.05 \\
\hline Procyon lotor & Raccoon & 2 & 1.31 \\
\hline Rodentia & Rodents & 59 & 6.60 \\
\hline Sigmodon hispidus & Cotton rat & 24 & 3.90 \\
\hline Sus scrofa & Domestic pig & 8 & 8.31 \\
\hline Sylvilagus sp. & Cottontail rabbit & 97 & 31.00 \\
\hline Mammal--very small & & 68 & 4.89 \\
\hline Mammal--small & & 17 & 3.67 \\
\hline Mammal--medium & & 8 & 3.40 \\
\hline Mammal--large & & 102 & 239.28 \\
\hline Mammal--very large & & 851 & $5,030.55$ \\
\hline Manmal & & 10,645 & $5,439.58$ \\
\hline Aves & Total Mammals & 12,211 & $15,208.22$ \\
\hline Anas sp. & Ducks & 6 & 5.15 \\
\hline Anatidae & Ducks and geese & 1 & 0.83 \\
\hline Branta cf. canadensis & Canada goose & 4 & 2.59 \\
\hline Callipepla squamata & Scaled quail & 3 & 0.46 \\
\hline Gallus domesticus & Chicken & 5 & 4.06 \\
\hline Meleagris gallopavo & Turkey & 11 & 13.73 \\
\hline Aves & Birds & 64 & 25.35 \\
\hline \multicolumn{3}{|c|}{ Total Birds } & 52.17 \\
\hline
\end{tabular}


Table 1-4, continued...

\begin{tabular}{|c|c|c|c|}
\hline Taxa & Common Name & Count & Weight (g) \\
\hline Reptilia & \multicolumn{3}{|l|}{ Reptiles } \\
\hline Alligator mississippiensis & Alligator & 10 & 21.47 \\
\hline Crotalus atrox & West. diamondback rattlesnake & 39 & 15.14 \\
\hline Elaphe sp. & Rat snakes & 8 & 2.00 \\
\hline Pseudomys sp. & Pond sliders & 3 & 1.18 \\
\hline Terrepene sp. & Box turtles & 18 & 8.34 \\
\hline Thamnophis sp. & Garter snakes & 1 & 0.34 \\
\hline Trionyx $\mathrm{sp}$. & Softshelled turtles & 24 & 35.13 \\
\hline Serpentes & Snakes & 2 & 0.69 \\
\hline Testudinata & Turtles & 10 & 5.83 \\
\hline \multicolumn{2}{|r|}{ Total Reptile } & 115 & 90.12 \\
\hline Aplodinotus grunniens & Freshwater drum & 1 & 0.48 \\
\hline Ictalurus sp. & Catfish & 18 & 5.98 \\
\hline Lepisosteus sp. & Gars & 2 & 0.43 \\
\hline Pylodictus olivaris & Bullhead catfish & 3 & 3.40 \\
\hline Osteichthyes & Unidentified fish & 53 & 12.55 \\
\hline \multicolumn{2}{|r|}{ Total Fishes } & 77 & 22.84 \\
\hline \multirow[t]{2}{*}{ Vertebrata } & Unidentified bone & 40 & 18.30 \\
\hline & Overall Totals & 12,537 & $15,391.65$ \\
\hline
\end{tabular}




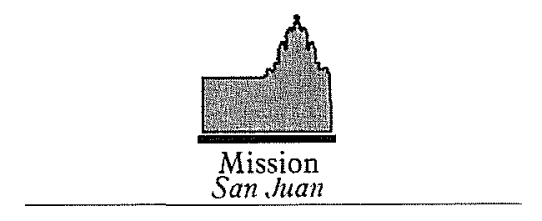

Table 1-5. Number of identified specimens (NISP) for each taxa

\begin{tabular}{|c|c|c|c|c|c|}
\hline Taxa & Common Name & Count & $\%$ & Weight (g) & $\%$ \\
\hline \multicolumn{6}{|c|}{ Mammalia $\quad$ Mammals } \\
\hline Bos taurus & Cattle & 60 & $14.1 \%$ & 2107.27 & $80.2 \%$ \\
\hline Canis sp. & Dog, wolf, or coyote & 26 & $6.1 \%$ & 74.64 & $2.8 \%$ \\
\hline Canis latrans & Covote & 1 & $0.2 \%$ & 47.46 & $1.8 \%$ \\
\hline Capra hircus & Domestic goat & 6 & $1.4 \%$ & 45.46 & $1.7 \%$ \\
\hline Didelphis virginianus & Opossum & 1. & $0.2 \%$ & 0.72 & $0.0 \%$ \\
\hline Equus sp. & Horse family & 1 & $0.2 \%$ & 10.69 & $0.4 \%$ \\
\hline Equus caballos & Horse & 3 & $0.7 \%$ & 20.51 & $0.8 \%$ \\
\hline Felis cf. domesticus & Domestic cat & 1 & $0.2 \%$ & 0.17 & $0.0 \%$ \\
\hline Lepus californicus & Blacktailed jackrabbit & 1 & $0.2 \%$ & 0.34 & $0.0 \%$ \\
\hline Neotoma sp. & Woodrats & 14 & $3.3 \%$ & 3.41 & $0.1 \%$ \\
\hline Odocoileus virginianus & White-tailed deer & 16 & $3.8 \%$ & 89.81 & $3.4 \%$ \\
\hline Ovis aries & Domestic sheep & 7 & $1.6 \%$ & 62.03 & $2.4 \%$ \\
\hline Perognathus sp. & Pocket mice & 1. & $0.2 \%$ & 0.05 & $0.0 \%$ \\
\hline Procyon lotor & Raccoon & 2 & $0.5 \%$ & 1.31 & $0.0 \%$ \\
\hline Sigmodon hispidus & Cotton rat & 24 & $5.6 \%$ & 3.90 & $0.1 \%$ \\
\hline Sus scrofa & Domestic pig & 8 & $1.9 \%$ & 8.31 & $0.3 \%$ \\
\hline Svlvilagus $\mathrm{sp}$. & Cottontail rabbit & 97 & $22.8 \%$ & 31.00 & $1.2 \%$ \\
\hline \multicolumn{2}{|r|}{ Total Mammals } & 269 & $63.3 \%$ & 2507.08 & $95.4 \%$ \\
\hline \multicolumn{6}{|c|}{ Birds } \\
\hline Anas $\mathrm{sp}$. & Ducks & 6 & $1.4 \%$ & 5.15 & $0.2 \%$ \\
\hline Branta cf. canadensis & Canada goose & 4 & $0.9 \%$ & 2.59 & $0.1 \%$ \\
\hline Callipepla squamata & Scaled quail & 3. & $0.7 \%$ & 0.46 & $<0.1 \%$ \\
\hline Gallus domesticus & Chicken & 5 & $1.2 \%$ & 4.06 & $0.2 \%$ \\
\hline \multirow[t]{2}{*}{ Meleagris gallopavo } & Turkey & 11 & $2.6 \%$ & 13.73 & $0.5 \%$ \\
\hline & & 29 & $6.8 \%$ & 25.99 & $1.0 \%$ \\
\hline \multicolumn{6}{|c|}{ Total Birds L } \\
\hline Alligator mississippiensis & Alligator & 10 & $2.4 \%$ & 21.47 & $0.8 \%$ \\
\hline Crotalus atrox & West. diamondback rattlesnake & 39 & $9.2 \%$ & 15.14 & $0.6 \%$ \\
\hline Elaphe sp. & Rat snakes & 8 & $1.9 \%$ & 2.00 & $0.1 \%$ \\
\hline Pseudomvs sp. & Pond sliders & 3 & $0.7 \%$ & 1.18 & $0.0 \%$ \\
\hline Terrepene sp. & Box turtles & 18 & $4.2 \%$ & 8.34 & $0.3 \%$ \\
\hline Thamnophis sp. & Garter snakes & 1 & $0.2 \%$ & 0.34 & $0.0 \%$ \\
\hline Trionyx sp. & Softshelled turtles & 24 & $5.6 \%$ & 35.13 & $1.3 \%$ \\
\hline & Total Reptiles & 103 & $24.2 \%$ & 83.60 & $3.2 \%$ \\
\hline Osteichthyes & Boney Fishes & & & & \\
\hline Aplodinotus grunniens & Freshwater drum & 1 & $0.2 \%$ & 0.48 & $<0.1 \%$ \\
\hline Ictalurus sp. & Catfish & 18 & $4.2 \%$ & 5.98 & $0.2 \%$ \\
\hline Lepisosteus $\mathrm{sp}$. & Gars & 2 & $0.5 \%$ & 0.43 & $<0.1 \%$ \\
\hline Pylodictus olivaris & Bullhead catfish & 3 & $0.7 \%$ & 3.40 & $0.1 \%$ \\
\hline & Total Fishes & 24 & $5.6 \%$ & 10.29 & $0.4 \%$ \\
\hline & Overall Totals & 425 & $100.0 \%$ & $2,626.96$ & $100.0 \%$ \\
\hline
\end{tabular}




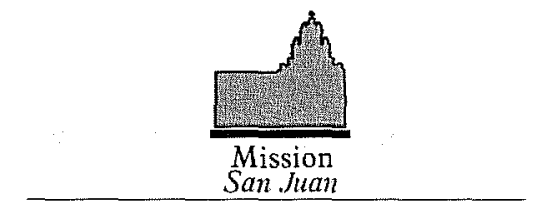

Table 1-6. Percent of total NISP bone weight for selected taxa

\begin{tabular}{|c|c|}
\hline Taxa Category & $\begin{array}{l}\text { Percent of Total NISP } \\
\text { Weight }\end{array}$ \\
\hline Cattle & $80.20 \%$ \\
\hline Goats, Sheep and Pigs & $4.40 \%$ \\
\hline Hunted Wild Mammals & $4.70 \%$ \\
\hline Birds & $1.00 \%$ \\
\hline Fish & $0.40 \%$ \\
\hline Turtles & $1.70 \%$ \\
\hline
\end{tabular}

\section{Butcher Marks}

Although this collection is too fragmented to allow useful examination of butchering practices, evidence of butchering and other tool marks were identified on 63 bones (.5 percent). Three bones displayed more than one type of butcher mark. Table 1-7 lists the types of markings and the number of bones on which the marks were observed. Only one bone was found to have been sawed, but was too fragmentary and weathered for identification of the type of saw cut (hand saw or machine saw). This bone was found in Level 2 of Unit 5 . About 66 percent $(n=42)$ of the bone which showed butcher marks had been chopped. Sixteen bones ( 25.4 percent) showed evidence of impact fractures, indicating that the bone had been deliberately broken open with a blunt object, presumably a hammerstone. This pattern of butcher marks, though, found on only a very small percentage of bone is typical of mission sites.

Table 1-7. Mission San Juan, butcher marks observed on bone

\begin{tabular}{|l|c|}
\hline \multicolumn{1}{|c|}{ Butcher Mark Type } & Count \\
\hline $\begin{array}{l}\text { Thin Cut Mark. Thin superficial cut, most likely } \\
\text { from a knife. }\end{array}$ & 2 \\
\hline $\begin{array}{l}\text { Thick Cut Mark. Thick superficial, from heavy } \\
\text { knife or small hatchet. }\end{array}$ & 2 \\
\hline $\begin{array}{l}\text { Chop Mark. Heavy, deep cut that may or may } \\
\text { not have completely severed the bone. }\end{array}$ & 42 \\
\hline $\begin{array}{l}\text { Saw Cut-Indeterminate. Bone is sawn-cut, but } \\
\text { method used cannot be determined. }\end{array}$ & 1 \\
\hline $\begin{array}{l}\text { Impact Scar. } \\
\text { Total }\end{array}$ & 63 \\
\hline
\end{tabular}




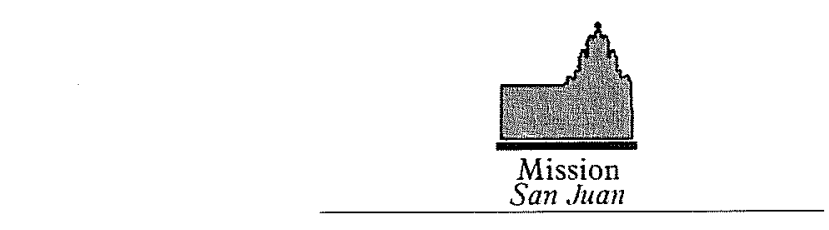

Burned Bone

Evidence of exposure to heat can indicate whether bone was routinely thrown into fire as a disposal method. Only 5.3 percent $(\mathrm{n}=662)$ of the bone from this collection showed evidence of heat alteration. Of these, more than half (55.3 percent) were calcined or partially calcined (Table 1-8). The duration and intensity of heating necessary to calcine bone is considerable (Lyman 1994). It is unlikely to occur during routine cooking, suggesting that deliberate burning of bone, presumably as part of a disposal method, was being carried out. However, when the percent of burned bone is examined by unit, a great deal of variation can be seen (Table 1-9). Units 2 and 3 have very low total sample counts and should not be considered with the others. Units 1, and 7-10 have much higher percentages of both total burned bone and heavily burned (i.e., calcined or partially calcined) bone than Units 4-6. At least some burning of bone as a disposal method is probably seen in Units 1 and 7-10. Unfortunately, the majority of the burned bone was not identifiable to taxa, with only 1 bovid and 1 deer identified.

\section{Evidence of Gnawing}

Only two bones in the collection showed evidence of tooth marks. Both had carnivore tooth marks, which were probably canid. The absence of rodent gnawing and rarity of carnivore gnawing indicates that either a high percentage of the bone was rendered unappealing to rats and dogs (presumably by boiling), or was buried at the time of disposal.

Table 1-8. Mission San Juan, stages of heat alteration exhibited by bone in test units

\begin{tabular}{|c|c|c|}
\hline Stage 1. Smoke stained & 55 & $8.3 \%$ \\
\hline Stage 2. Charred & 241 & $36.4 \%$ \\
\hline Stage 3. Partially calcined & 211 & $31.9 \%$ \\
\hline Stage 4. Calcined & 155 & $23.4 \%$ \\
\hline Total & 662 & $100.0 \%$ \\
\hline
\end{tabular}

\section{Pathology}

Pathological conditions are not readily identified on highly fragmented bone. However, three bones in this collection showed evidence of pathology. One was the proximal tibia of a black-tailed jackrabbit (Lepus californicus) which showed arthritic lipping of the articular surface. The second was an unidentified rodent tibia with a large foramen on the posterior surface near the proximal end. This hole appeared to be a congenital malformation.

The third bone exhibiting a pathological condition was the first phalange of a deer (Odocoileus virginianus), which was grossly deformed by excessive bone growth (Figure 1-20). The nature of the excessive growth and the presence of several small cloacas along the posterior surface suggest that at least part of the deformity was a response to osteomyelitis, a severe bacterial infection of the bone. However, the infection appears to be secondary to either crushing trauma to the medial condyle, or possibly a tumor invading the distal end of the bone.
Table 1-9. Mission San Juan, total burned bone and heavily burned bone by unit

\begin{tabular}{|l|r|r|r|r|}
\hline $\begin{array}{c}\text { Unit } \\
\text { (Sample size) }\end{array}$ & $\begin{array}{c}\text { Burned } \\
\text { Bone }\end{array}$ & \multicolumn{1}{c|}{$\%$} & $\begin{array}{c}\text { Stages } \\
3-4\end{array}$ & \multicolumn{1}{c|}{$\%$} \\
\hline Unit 1 $(n=946)$ & 68 & $7.2 \%$ & 31 & $3.3 \%$ \\
\hline Unit 2 $(n=33)$ & 6 & $18.2 \%$ & 3 & $9.1 \%$ \\
\hline Unit 3 (n=9) & 7 & $77.8 \%$ & 1 & $11.1 \%$ \\
\hline Unit 4 (n=525) & 3 & $0.6 \%$ & 2 & $0.4 \%$ \\
\hline Unit 5 ( $n=561)$ & 8 & $1.4 \%$ & 1 & $0.2 \%$ \\
\hline Unit 6 $(n=1659)$ & 6 & $0.4 \%$ & 6 & $0.4 \%$ \\
\hline Unit 7 ( $n=416)$ & 29 & $7.0 \%$ & 14 & $3.4 \%$ \\
\hline Unit 8 (n=5765) & 309 & $5.4 \%$ & 205 & $3.6 \%$ \\
\hline Unit 9 (n=2041) & 204 & $10.0 \%$ & 96 & $4.7 \%$ \\
\hline Unit 10 (n=131) & 22 & $16.8 \%$ & 7 & $5.3 \%$ \\
\hline
\end{tabular}




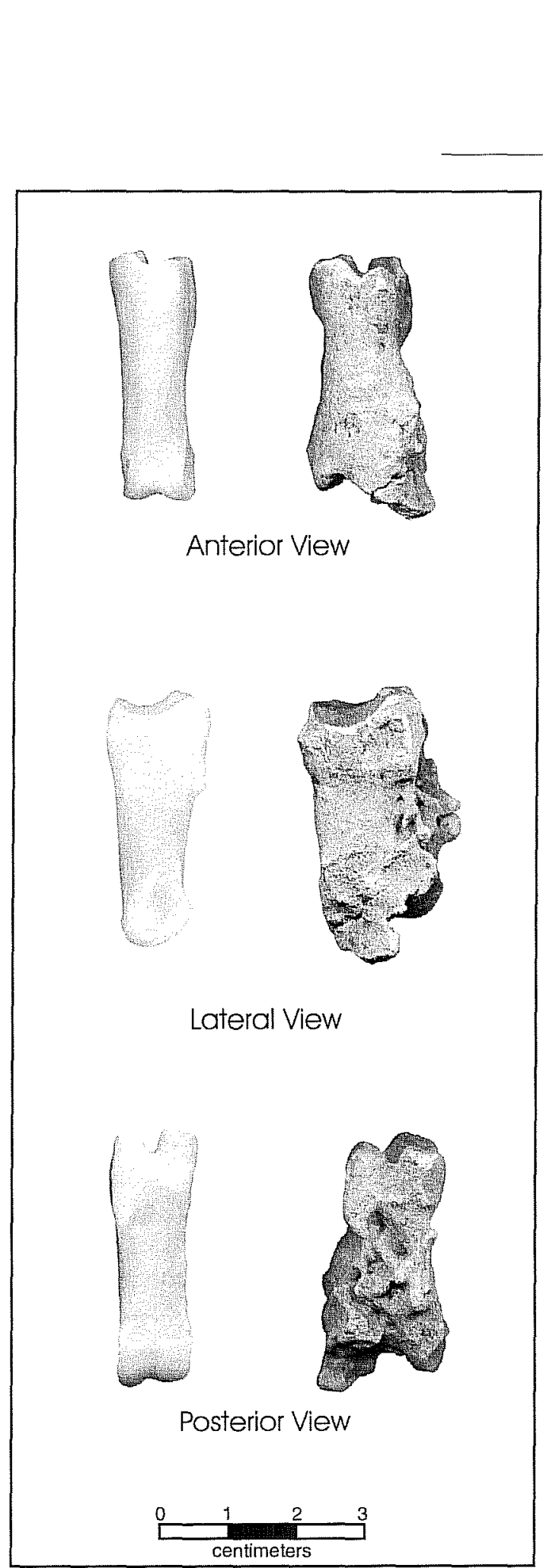

Figure 1-20. Three views of a grossly, deformed phalange of a deer (right); compared to a normal phalange from the CAR comparative collection.

\section{Discussion}

The collection is highly fragmented, but there is some variation in the degree of fragmentation between units. Three measures can be used to compare units:

1) Examine percentage of NISP per unit. In general, the higher the degree of fragmentation, the lower the percentage of NISP will be. Table 1-10 shows the percent of NISP for each unit. Unit 9 has, by far, the highest percentage of NISP, 11.3 percent. Unit 2 has the next highest, 6.1 percent, while all others range between 0.0 percent and 3.1 percent, averaging 1.7 percent. With the exception of Units 9 and 2 the test units show very poor identifiability due to high degrees of fragmentation.

2) A second method of comparing relative fragmentation is to consider that only very highly fragmented bone cannot be identified at least to class. In addition, only very fragmented mammalian bone cannot be assigned to a size category. Thus, a method to assess fragmentation is to note the percentage of total bone in each unit that was minimally identifiable, that is, identifiable only as Vertebrata, or as Mammal, but so fragmented that the size of the animal cannot be estimated. Table 111 ranks the test units by the percentage of bone that was minimally identified. Unit 9 has the lowest percentage of minimally identifiable bone, followed by Units 2,4 , and 5, implying that they are the least fragmented.

3) A final way to assess degree of fragmentation is average bone weight. Table $1-12$ shows the ten test units ranked by average bone weight. This table shows that Unit 4 has the highest average, followed by Units 5 and 9, implying that they are the least fragmented.

Two of three measures of relative fragmentation indicated Unit 9 as the least fragmented. The third, average bone weight, may be influenced by the large number of small mammals, especially cottontail rabbit, which were identified in Unit 9. Once this allowance is taken into consideration, it is clear that Unit 9 contains the least fragmented bone. 
Table 1-10. San Juan, percent of NISP by unit

\begin{tabular}{|c|r|}
\hline Test Unit & \% NISP \\
\hline Unit 1 & $2.0 \%$ \\
\hline Unit 2 & $6.1 \%$ \\
\hline Unit 3 & $0.0 \%$ \\
\hline Unit 4 & $2.1 \%$ \\
\hline Unit 5 & $1.8 \%$ \\
\hline Unit 6 & $2.3 \%$ \\
\hline Unit 7 & $3.1 \%$ \\
\hline Unit 8 & $1.2 \%$ \\
\hline Unit 9 & $11.3 \%$ \\
\hline Unit 10 & $0.8 \%$ \\
\hline
\end{tabular}

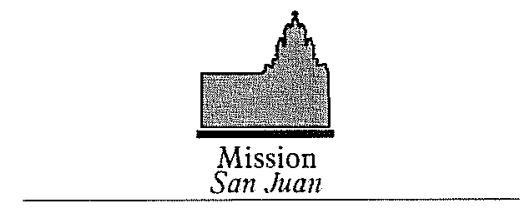

Table 1-11. San Juan, percent of minimally identified bone by unit

\begin{tabular}{|c|r|}
\hline & $\%$ w/ \\
Test Unit & \multicolumn{1}{|c|}{ Minimal } \\
\hline Unit 3 & $100.0 \%$ \\
\hline Unit 8 & $92.4 \%$ \\
\hline Unit 6 & $89.2 \%$ \\
\hline Unit 10 & $83.2 \%$ \\
\hline Unit 1 & $82.7 \%$ \\
\hline Unit 7 & $79.3 \%$ \\
\hline Unit 5 & $77.2 \%$ \\
\hline Unit 4 & $77.0 \%$ \\
\hline Unit 2 & $75.8 \%$ \\
\hline Unit 9 & $69.3 \%$ \\
\hline
\end{tabular}

Table 1-12. San Juan, average bone weight

by unit

\begin{tabular}{|c|r|}
\hline Test Unit & $\begin{array}{r}\text { Ave. Bone } \\
\text { wgt. (g) }\end{array}$ \\
\hline Unit 6 & 0.6 \\
\hline Unit 10 & 0.7 \\
\hline Unit 3 & 0.8 \\
\hline Unit 7 & 0.8 \\
\hline Unit 8 & 0.9 \\
\hline Unit 1 & 1.1 \\
\hline Unit 2 & 1.3 \\
\hline Unit 9 & 1.7 \\
\hline Unit 5 & 2.0 \\
\hline Unit 4 & 2.3 \\
\hline
\end{tabular}

The possible causes of fragmentation are many. Mission San Juan has been in use since it was founded on this site, in 1731, so that some of the damage to the bone could be from trampling (Schiffer 1987:126127). Weathering can also make bone very friable and subject to breakage (Lyman 1994). Although no formal study of degrees of weathering was undertaken for this project, evidence of considerable weathering damage was noted in some of the units, especially Unit 8. Construction activities which occurred chiefly in and around Unit 8 -where the majority of the bone was found near a post-Colonial structure-potentially, was an additional source of bone fragmentation.

Cultural practices such as shattering of long bones to extract marrow and boiling bone to extract bone grease are probably factors contributing to fragmentation. To extract marrow, long bones are usually broken, often at the mid-point of the diaphysis, and the marrow extracted (Binford 1981). The extraction of bone grease involves breaking bone, especially the ends of long bones, which have a high fat content into small pieces and then boiling the bone for an extended period. Bone fat is then periodically skimmed from the surface of the water (Brink 1997:260; Vehik 1977:171). The shattering of bone ends leaves them much less identifiable. The boiling process removes nutrients making the bone more friable after burial (Nicholson 1996; Vehik 1977:173).

If most of the fragmentation is caused by mechanical factors such as trampling or disturbance by construction activities, then the bone with highest density should be the least impacted (Lyman 1994). If most of the fragmentation was caused only by bone marrow extraction, then large numbers of identifiable long bone ends should be present. If a large percentage of the fragmentation is caused by processing for bone grease, then we should expect to see very few long bone ends and centrums of vertebrae, higher numbers of bone with low bone grease yield, such as foot bones, and large numbers of very fragmented, unidentifiable mammal bone (Vehik 1977:172).

It has been noted that there were large numbers of bone fragments that could be identified only as Vertebrate or Mammal. In order to determine, if this collection resembles the pattern expected that bone grease was being extracted, bone identified as bovid (i.e., either Bos taurus or Bovinae) was divided into 


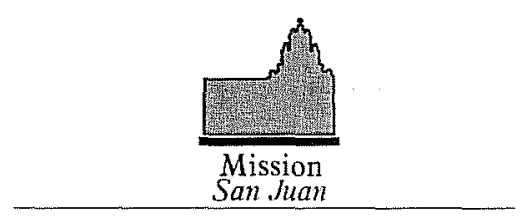

three categories based on data from Binford (1978), Brink (1997), and Vehik (1977). These categories include:

1) Elements with high bone grease utility, including the major long bones;

2) Elements with moderate bone grease utility, including metapodials and centrums of vertebrae;

3) Elements with low bone grease utility, including carpals, tarsals, ribs, head (excluding teeth), and foot bones.

Figure 1-21 shows the counts of bone in each of these categories. It is expected, if a large part of the fragmentation of this bone was the result of processing for bone grease, the bones with the highest bone grease utility have the lowest counts, and the bones with lowest bone grease utility have the highest counts. This is especially important because bones with high bone grease utility tend to be the most dense bones in the body (Brink 1997:265), and are thus less susceptible to most other causes of fragmentation such as trampling and post depositional disturbance.

Such heavy processing of bone is common but not universal in Colonial sites. Bone from three recent excavations at Mission San José (Meissner 1998a, 1999a, $1999 \mathrm{~b})$ ranged in average bone weight from $.83 \mathrm{~g}$ to $1.21 \mathrm{~g}$, averaging $.99 \mathrm{~g}$. On the other hand, the bone excavated near the southeast gateway at San José averaged $3.15 \mathrm{~g}$ (Hunziker 1998), and some of the bone excavated by Clark (1978) in the northern part of the compound averaged $7.80 \mathrm{~g}$ (Meissner 1999b). Recent excavations at Mission Nuestra Señora del Refugio (41RF1), in Refugio County, recovered 121,398 pieces of bone, most of which was found in two large trash pits. The average bone weight was $2.5 \mathrm{~g}$ (C. Tennis, personal communication, 1998). The Colonial bone bed excavated in 1978 at Mission San Antonio de Valero had an average bone weight of $9.0 \mathrm{~g}$. Most of the long bones had been broken in the middle to extract marrow, but bone ends were largely intact (Meissner 1998b), indicating that processing for bone grease was not carried out.

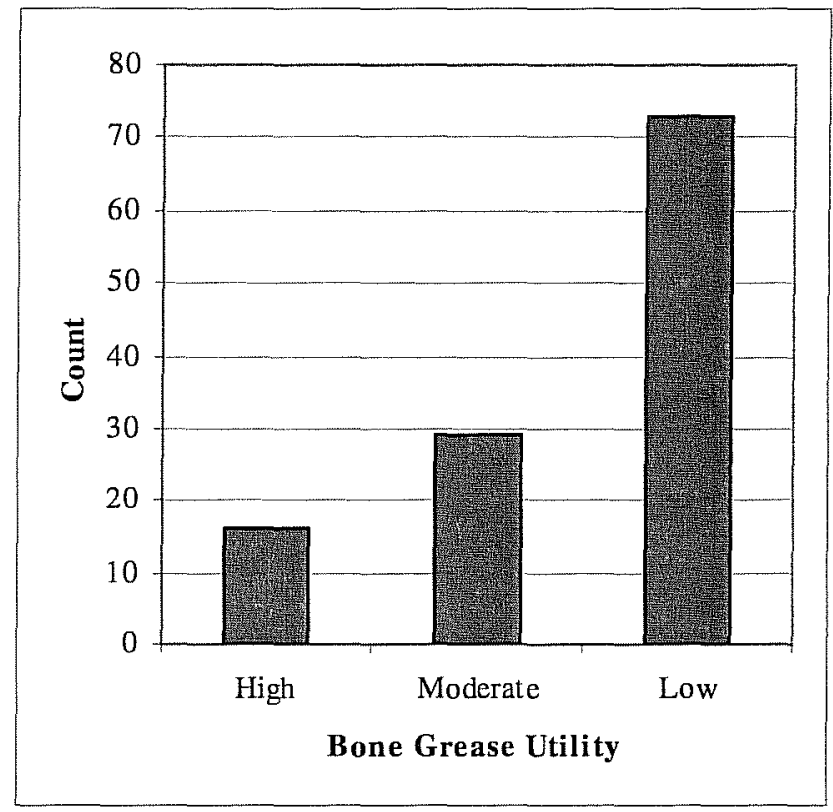

Figure 1-21. San Juan, Count of bovid elements in high, moderate, and low marrow bone grease utility categories.

This is not to say that all fragmentation found in these test units was the result of bone grease processing. The likelihood of considerable post-depositional breakage can be seen in the relatively low average bone weight (Table 1-12) and high percentage of minimally identifiable bone (Table 1-11) of Unit 8, which is not surprising, given the close proximity of both Colonial and post-Colonial structures.

A more graphic example of this is Unit 9, which displays 5 distinct "floors", and contains only Colonial period artifacts below the first of these floors in Level 4. The degree of fragmentation of bone, as measured by percent NISP undergoes a distinct shift beneath the lowest of these floors, beginning with Level 6 (Table 1-13). The bone deposited from the surface to the bottom of the lowest floor would have been subject to much more trampling than the bone beneath the lowest floor. 


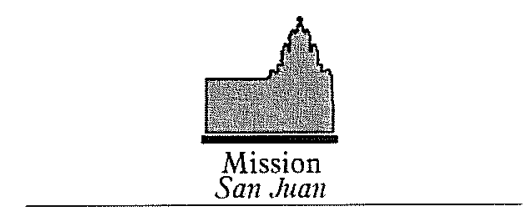

\section{Unit 9}

A more detailed look at the bones in Unit 9 seems warranted, because it seems the least disturbed of all of the units.

Unit 9, contains several "floors", which tend to indicate a prolonged period of intensive use of the area, and also because artifact levels below Level 4 appear to be undisturbed Colonial.
Table 1-14 presents a detailed look at the identified bone recovered below Level 4. Level 6 looks very much like a summary of a typical Colonial bone deposit, dominated by cattle bone. However, it is interesting that below Level 6 only a single cattle bone was identified. Additionally, below Level 9 no domestic animals were identified. Since some Colonial ceramics were discovered all the way to Level 12 , it is clear that these levels were deposited after the arrival of the Spanish at this location.

Table 1-13. San Juan, percent of NISP by level in Unit 9

\begin{tabular}{|l|r|}
\hline Level & $\%$ NISP \\
\hline Level 1 & $0.0 \%$ \\
\hline Level 2 & $0.0 \%$ \\
\hline Level 3 & $0.6 \%$ \\
\hline Level 4 & $1.4 \%$ \\
\hline Level 5 & $0.0 \%$ \\
\hline Level 6 & $11.0 \%$ \\
\hline Level 7 & $18.8 \%$ \\
\hline Level 8 & $9.7 \%$ \\
\hline Level 9 & $16.8 \%$ \\
\hline Level 10 & $18.4 \%$ \\
\hline Level 11 & $5.0 \%$ \\
\hline Level 12 & $32.4 \%$ \\
\hline
\end{tabular}




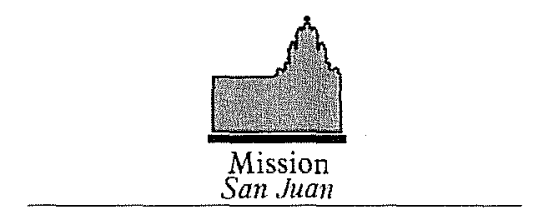

Table 1-14. San Juan, percent of NISP by level (below Level 4) in Unit 9

\begin{tabular}{|c|c|c|c|c|c|c|c|c|c|}
\hline $\begin{array}{l}\quad \text { Taxon } \\
\text { Level } 5 \text { ( } \mathrm{n}=16) \\
\text { No bone identified to } \mathrm{g} \\
\text { Level } 6(\mathrm{n}=435)\end{array}$ & $\begin{array}{l}\text { NISP } \\
\text { enus }\end{array}$ & $\%$ & Wgt. (g) & $\%$ & Level $9(n=666)$ & NISP & $\%$ & Wgt. (g) & $\%$ \\
\hline Bos taurus & 21 & $43.8 \%$ & 1310.27 & $98.0 \%$ & Capra hircus & 3 & $2.7 \%$ & 33.29 & $43.6 \%$ \\
\hline Didelphis virginiana & 1 & $2.1 \%$ & 0.72 & $0.1 \%$ & Equus sp. & 1. & $0.9 \%$ & 10.69 & $14.0 \%$ \\
\hline Felis domesticus & 1 & $2.1 \%$ & 0.17 & $0.0 \%$ & Lepus californicus & 1 & $0.9 \%$ & 0.34 & $0.4 \%$ \\
\hline Neotoma sp. & 2 & $4.2 \%$ & 0.88 & $0.1 \%$ & Neotoma sp. & 1 & $0.9 \%$ & 0.46 & $0.6 \%$ \\
\hline Ovis aries & 3 & $6.3 \%$ & 13.43 & $1.0 \%$ & Sigmodon hispidus & 8 & $7.1 \%$ & 0.78 & $1.0 \%$ \\
\hline Sylvilagus sp. & 7 & $14.6 \%$ & 2.40 & $0.2 \%$ & Sylvilagus sp. & 62 & $54.9 \%$ & 17.21 & $22.5 \%$ \\
\hline Total Mammais & 35 & $72.9 \%$ & 1327.87 & $99.3 \%$ & Total Mammals & 76. & $67.3 \%$ & 62.77 & $82.2 \%$ \\
\hline Gallus domesticus & 2 & $4.2 \%$ & 1.20 & $0.1 \%$ & Anas sp. & 1 & $0.9 \%$ & 0.44 & $0.6 \%$ \\
\hline Meleagris gallopavo & 3 & $6.3 \%$ & 5.88 & $0.4 \%$ & Brants sp. & 2 & $1.8 \%$ & 0.82 & $1.1 \%$ \\
\hline Total Birds & 5 & $10.4 \%$ & 7.08 & $0.5 \%$ & Gallus domesticus & 1 & $0.9 \%$ & 1.42 & $1.9 \%$ \\
\hline Thamnophis sp. & 1 & $2.1 \%$ & 0.34 & $0.0 \%$ & Total Birds & 4 & $3.5 \%$ & 2.68 & $3.5 \%$ \\
\hline Total Reptiles & 1 & $2.1 \%$ & 0.34 & $0.0 \%$ & Crotalus atrox & 21 & $18.6 \%$ & 7.21 & $9.4 \%$ \\
\hline Ictalurus sp. & 7 & $14.6 \%$ & 2.30 & $0.2 \%$ & Elaphe sp. & 5 & $4.4 \%$ & 1.02 & $1.3 \%$ \\
\hline Total Fish & 7 & $14.6 \%$ & 2.30 & $0.2 \%$ & Thamnophis sp. & 1 & $0.9 \%$ & 0.34 & $0.4 \%$ \\
\hline Total NISP & 48 & $1000 \%$ & 1337.59 & $100.0 \%$ & Total Reptiles & 27 & $23.9 \%$ & 8.57 & $11.2 \%$ \\
\hline \multirow{2}{*}{\multicolumn{5}{|c|}{ Note: Bottom of Floor 5}} & Ictalurus sp. & 4 & $3.5 \%$ & 1.62 & $2.1 \%$ \\
\hline & & & & & Lepisosteus sp. & 1 & $0.9 \%$ & 0.09 & $0.1 \%$ \\
\hline Level $7(n=32)$ & & & & & Pylodictus olivaris & 1 & $0.9 \%$ & 0.62 & $0.8 \%$ \\
\hline Neotoma sp. & 2 & $8.7 \%$ & 0.88 & $6.2 \%$ & Total Fish & 6. & $5.3 \%$ & 2.33 & $3.1 \%$ \\
\hline Sylvilagus sp. & 7 & $30.4 \%$ & 2.40 & $16.9 \%$ & Total NISP & 113 & $100.0 \%$ & 76.35 & $100.0 \%$ \\
\hline Total Mammals & 9 & $39.1 \%$ & 3.28 & $23.0 \%$ & \multirow{2}{*}{\multicolumn{5}{|c|}{ Level $10(n=49)$}} \\
\hline Gallus domesticus & 2 & $8.7 \%$ & 1.20 & $8.4 \%$ & & & & & \\
\hline Meleagris gallopavo & 3. & $13.0 \%$ & 5.88 & $41.3 \%$ & Sigmodon hispidus & 2 & $22.2 \%$ & 0.44 & $17.2 \%$ \\
\hline Total Birds & 5 & $21.7 \%$ & 7.08 & $49.8 \%$ & Sylvilagus sp. & 5 & $55.6 \%$ & 1.13 & $44.1 \%$ \\
\hline Crotalus atrox & 2 & $8.7 \%$ & 1.57 & $11.0 \%$ & Total Mammals & 7 & $77.8 \%$ & 1.57 & $61.3 \%$ \\
\hline Total Reptiles & 2 & $8.7 \%$ & 1.57 & $11.0 \%$ & Crotalus atrox & 2 & $22.2 \%$ & 0.99 & $38.7 \%$ \\
\hline Ictalurus sp. & 7 & $30.4 \%$ & 2.30 & $16.2 \%$ & Total Reptiles & 2 & $22.2 \%$ & 0.99 & $38.7 \%$ \\
\hline Total Fish & 7 & $30.4 \%$ & 2.30 & $16.2 \%$ & Total NISP & 9 & $100.0 \%$ & 2.56 & $100.0 \%$ \\
\hline Total NISP & 23 & $100.0 \%$ & 14.23 & $100,0 \%$ & \multirow{2}{*}{\multicolumn{5}{|c|}{ Level $11(n=40)$}} \\
\hline \multirow{2}{*}{\multicolumn{5}{|c|}{ Level $8(n=401)$}} & & & & & \\
\hline & & & & & Sigmodon hispidus & 1 & $50.0 \%$ & 0.08 & $32.0 \%$ \\
\hline Bos taurus & 1 & $4.0 \%$ & 15.32 & $52.5 \%$ & Total Mammals & 1 & $50.0 \%$ & 0.08 & $32.0 \%$ \\
\hline Canis sp. & 1 & $4.0 \%$ & 0.67 & $2.3 \%$ & Callipepla squamata & 1 & $50.0 \%$ & 0.17 & $68.0 \%$ \\
\hline Capra hircus & 1 & $4.0 \%$ & 2.77 & $9.5 \%$ & Total Birds & 1 & $50.0 \%$ & 0.17 & $68.0 \%$ \\
\hline Sigmodon hispidus & 5 & $20.0 \%$ & 1.19 & $4.1 \%$ & Total NISP & 2 & $100.0 \%$ & 0.25 & $100.0 \%$ \\
\hline Sylvilagus sp. & 10 & $40.0 \%$ & 5.43 & $18.6 \%$ & \multirow{2}{*}{\multicolumn{5}{|c|}{ Level $12(n=37)$}} \\
\hline Total Mammals & 18 & $72.0 \%$ & 25.38 & $87.0 \%$ & & & & & \\
\hline Brant sp. & 2 & $8.0 \%$ & 1.77 & $6.1 \%$ & Sigmodon hispidus & 6 & $50.0 \%$ & 0.99 & $34.6 \%$ \\
\hline Callipepla squamata & 2 & $8.0 \%$ & 0.29 & $1.0 \%$ & Sylvilagus sp. & 5 & $41.7 \%$ & 1.73 & $60.5 \%$ \\
\hline Total Birds & 4 & $16.0 \%$ & 2.06 & $7.1 \%$ & Total Mammals & 11 & $91.7 \%$ & 2.72 & $95.1 \%$ \\
\hline Trionix sp. & 3 & $12.0 \%$ & 1.74 & $6.0 \%$ & Ictalurus sp. & 1 & $8.3 \%$ & 0.14 & $4.9 \%$ \\
\hline Total Reptiles & 3 & $12.0 \%$ & 1.74 & $6.0 \%$ & Total Fishes & 1 & $8.3 \%$ & 0.14 & $4.9 \%$ \\
\hline Total NISP & 25 & $100.0 \%$ & 29.18 & $100.0 \%$ & Total NISP & 12 & $1000 \%$ & 2.86 & $100.0 \%$ \\
\hline
\end{tabular}




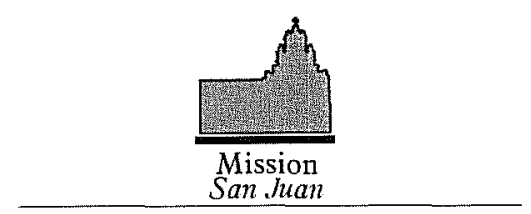

Finally, it is in Unit 9, where the absence of the usually ubiquitous cattle bone may represent a period in the mission history when cattle were less readily available, probably at the very beginning of the Spanish occupation.

\section{Faunal Remains - Shovel Tests}

A total of 238 pieces of bone were recovered from a series of 12 shovel tests outside the west wall of the mission adjacent to the test units. Only 3 bones ( 1 percent) from these tests were identified to the genus taxonomic level. Table $1-15$ shows bone counts for each shovel test. Table 1-16 shows the taxa identified from the shovel tests.

Table 1-15. San Juan, bone counts from shovel tests

\begin{tabular}{|r|r|}
\hline \multicolumn{2}{|c|}{ Outside wall } \\
\hline St \# & Ct. \\
\hline 1 & 42 \\
\hline 2 & 45 \\
\hline 3 & 19 \\
\hline 4 & 21 \\
\hline 5 & 77 \\
\hline 7 & 17 \\
\hline 8 & 8 \\
\hline 9 & 2 \\
\hline 10 & 5 \\
\hline 11 & 1 \\
\hline 12 & 1 \\
\hline Total & $\mathbf{2 3 8}$ \\
\hline
\end{tabular}

Table 1-16. San Juan, taxa identified from shovel tests

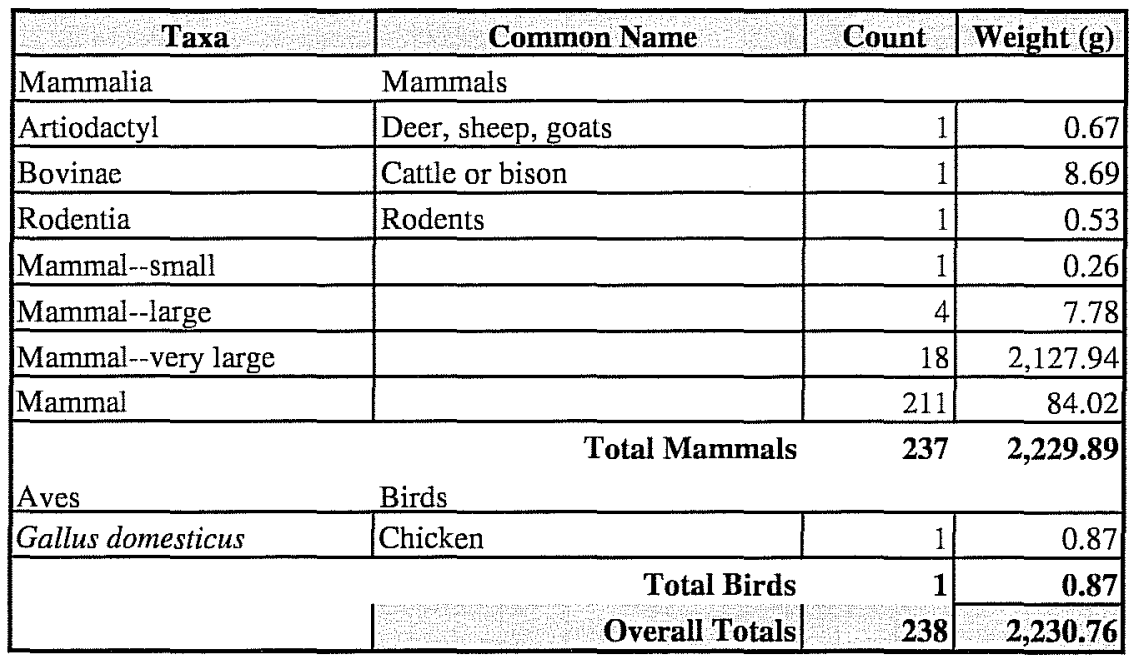




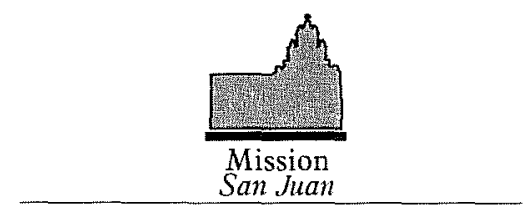

\title{
Conclusion
}

\begin{abstract}
About 85 percent $(n=10,645)$ of the total bone from the test units was mammalian bone too fragmented to identify further. Only 3.4 percent could be identified to the genus taxonomic level. This extreme fragmentation limits the confidence that can be placed on any estimations of animal use at San Juan. Possible reasons for this fragmentation include disturbance by construction, trampling, and processing of bone for extraction of bone grease. The relative absence of long bone ends and centrums of vertebrae and the high numbers of small fragments of bone suggest that much of the bone was processed for bone grease (Vehik 1977:172).
\end{abstract}

The few identifiable bones represent a meat diet consisting mostly of beef augmented by hunted animals, especially cottontail rabbits, and small domestic artiodactyls such as sheep and goats. The pattern is similar to that seen in faunal assemblages from recent excavations at San José, the main difference being the large number of rabbits identified in this collection. Rabbits made up only a small percentage of the total NISP at Mission San José, averaging only 9 percent of the NISP in four recent projects (Hunziker 1998;Meissner 1998a, 1999a, 1999b). However, even though rabbits are more common in this collection than is usually seen, they still comprise only a small percentage of the bone weight (1.2 percent) and were not a major component of the diet.

Unit 9 allows a more detailed look at bone deposited over time at the missions. The absence of cattle bone below Level 8 and the absence of domestic animal bone below Level 9 suggest that the bone deposited in these lower levels was placed there early in the history of the mission. 


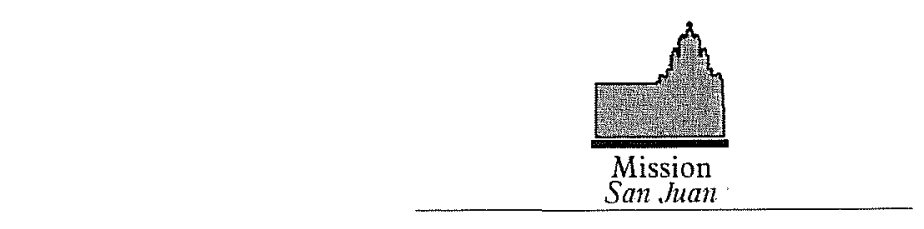

\section{Oxidizable Carbon Ratio Dating}

\author{
Douglas S. Frink
}

The oxidizable carbon ratio (OCR) testing conducted on soil strata from Unit 9 produced an overall dating sequence from A.D. 1930 back to A.D. 747 (Table 1-17). With the exception of Level 4, which produced a younger than expected date, all dating of these strata followed a normal chronological sequence from younger to older. Levels 3, 4, and 5 represent flooring episodes so it is not unexpected to see variations in soil dating where prepared surfaces have incorporated soils from other areas. This may explain the incongruency seen in the Level 4 date.
OCR dating from Levels 10 and 11 from Unit 9, does not correlate to the dating of ceramics from these levels. Both levels are below the levels with prepared floor surfaces, it might be expected that root and/or rodent disturbances may have lead to the downward migration of cultural material from later times into zones of much earlier soils.

Dates assigned to Levels 6-9 fall firmly within the Colonial period occupation of the site and correlate accurately with the ceramic data from these levels. Level 5 was devoid of artifactual material and, therefore, no confirmation of OCR dating of this level is available. Levels 1-4 consist of a chronological mixture from the Colonial to the Historic period, consequently, the artifactual materials offer no collaboration of the OCR dates assigned.

Table 1-17. San Juan, OCR dating sequence from Unit 9

\begin{tabular}{|c|c|c|c|}
\hline Level & OCR Date (YBP 1950) & Calendar Date (STD) & ACT \# \\
\hline 1 & $20 \pm 0$ & 1930 & 3716 \\
\hline 2 & $86 \pm 2$ & $1862-1866$ & 3706 \\
\hline 3 & $88 \pm 2$ & $1860-1864$ & 3707 \\
\hline 4 & $78 \pm 2$ & $1870-1874$ & 3708 \\
\hline 5 & $98 \pm 2$ & $1850-1854$ & 3709 \\
\hline 6 & $112 \pm 3$ & $1835-1841$ & 3710 \\
\hline 7 & $171 \pm 5$ & $1774-1784$ & 3711 \\
\hline 8 & $200 \pm 5$ & $1745-1755$ & 3712 \\
\hline 9 & $203 \pm 6$ & $1741-1753$ & 3713 \\
\hline 10 & $541 \pm 16$ & $1393-1425$ & 3714 \\
\hline 11 & $639 \pm 19$ & $1292-1330$ & 3717 \\
\hline 12 & $1103 \pm 33$ & $814-880$ & 3715 \\
\hline
\end{tabular}




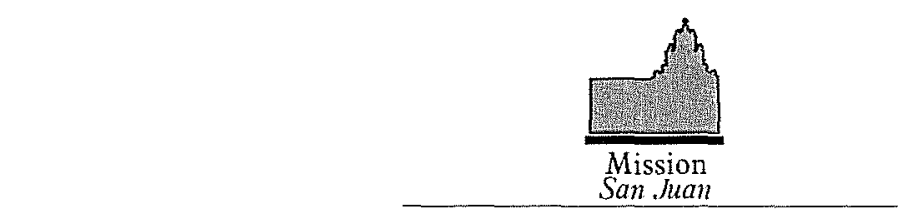

\section{Phytolith Analysis}

\author{
John G. Jones
}

\section{Background}

In recent years, phytoliths have proven to be extremely useful in Paleoenvironmental studies (Rovner 1983; Piperno 1988). These organically derived silicates are frequently preserved when other organic remains, including fossil pollen, have been lost. Although phytoliths are not produced in all plants, and in many cases are not diagnostic below the family level, they are particularly strong in the grass family (Brown 1984; Twiss 1987). Most grasses produce an abundance of phytoliths that are usually diagnostic to the tribe or even genus level. They are also particularly useful in the identification of ancient cultigens, and Zea mays (maize), and sometimes other domesticated grains, such as, Cucurbita (squash) and Phaseolus (beans), can be identified by their diagnostic phytoliths.

Phytolith analysis has a number of limitations, however, that must be considered. Unlike pollen, not all plants produce phytoliths. Phytolith production is most marked among Monocots, particularly in the grasses and sedges, although a number of significant Dicots are also phytolith producers. Also, unlike pollen, many plants produce the same basic phytolith types, thus genetic or even family-level identifications are often not possible.

Phytoliths are subject to many of the same rules of dispersal as are pollen grains. Occurring in the same size range and of approximately the same weight as pollen grains, phytoliths can be readily picked up by both wind and water and can sometimes be transported great distances. Most phytoliths in the sediment record were probably introduced into the soil through the natural in situ decomposition of the parent plant. Humans can also affect fossil phytolith assemblages in that phytolith-producing plants are often deliberately transported into and away from archaeological sites, affecting the fossil record. Therefore, caution must be employed when interpreting fossil phytolith assemblages.

\section{Methodology}

The samples, obtained from eight distinct "floors" of Unit 9 of Mission San Juan, were processed using techniques developed at the Texas A\&M University Palynology Laboratory. The soil samples were initially quantified (10 grams) and placed in beakers. First, carbonates were removed with $10 \% \mathrm{HCl}$. The samples were next rinsed, screened through 150-micron mesh, and a series of "short spins" was initiated to remove residual hydrochloric acid and facilitate the removal of clay particles and the smallest phytoliths. This step is necessary as phytoliths smaller than $2-3$ microns are rarely identifiable or valuable. Following this step, the samples were sonicated in a Delta D-5 ultrasonic generator for a period of 30 seconds, and several additional short spins were performed. These steps facilitated the removal of most of the fine clays.

The residues were next transferred to glass $100 \mathrm{ml}$ tubes and Schulze's solution (42\% Nitric Acid and Potassium Chlorate) was added to each sample. The samples were placed in a boiling water bath for approximately three hours or until all organic traces had been removed. Next, the samples were centrifuged and rinsed until neutral. Following this treatment, $5 \% \mathrm{KOH}$ was added to the residues to remove any additional humates. After additional rinsing in distilled water, the residue was transferred to a $300 \mathrm{ml}$ glass beaker, and the samples were fractionated in a water column. Here, samples were separated into two size categories: 3-25 microns and 25-150 microns. After fractionation, the residues were transferred to $15-\mathrm{ml}$ tubes and the remaining water was removed in preparation for heavy density separation. Here, Zinc Bromide 


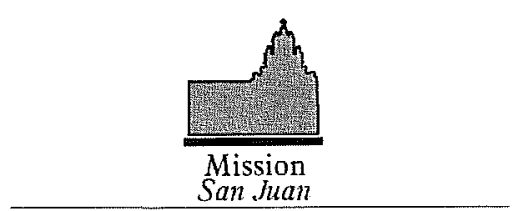

(Sp.G.2.38) was added to the samples, which were then spun at high speeds for 10 minutes. The lighter phytolith fraction was collected and the heavy density separation step was repeated, again collecting the lighter phytoliths. An abundance of phytoliths was collected from all the samples.

The phytoliths were next rinsed and transferred to absolute ethanol for curation. A single drop containing phytoliths was added to a cover slip and allowed to dry. A drop of Meltmount adhesive (refractive index 1.539) was added to the cover slip, and a permanent slide was made for each fraction of each sample.

Slides were examined at high magnification (1000$1250 \mathrm{x}$ ) using oil immersion and differential interference contrast settings on a Jenaval compound stereomicroscope. Identifications were confirmed through reference materials and published keys and descriptions. Grass phytolith types were identified based on types outlined by Fredlund and Tieszen (1994).

Among phytolith researchers, there is no established procedure for how many phytoliths should be counted to establish a representative record of past conditions. In the case of pollen analysis, most researchers count a minimum of 200 grains as suggested by Barkley (1934). Many phytolith researchers will count a specific number of slide scans, however, with this technique significant variations in phytolith numbers are frequently obtained. In this instance, we decided to count a minimum of 300 phytoliths from both the coarse and fine fraction. As each size fraction contains different phytolith types (bulliform cells, elongates and hair cells in the coarse fraction; diagnostic short grass cells in the fine fraction), it was considered important to quantify each fraction separately. For graphic purposes, both the coarse- and finefraction assemblages have been included.

\section{Results}

Phytoliths identified in the San Juan samples are presented in Table 1-18 and Figure 1-22. Well-preserved fossil phytoliths were identified in all of the San Juan samples. Most phytoliths, as expected, were from the abundant grasses. Grass phytoliths identified in the coarse fraction include bulliform Poaceae forms, elongates, and hair/edge phytoliths. Undifferentiated bulliform cells, the most common phytolith encountered, are probably derived largely from grasses. However, this type can be produced in dicotyledonous plants as well, thus it has been separated from the definite grass forms. Likewise, rod-shaped phytoliths can come from a variety of plants and no taxonomic significance should be attached to these. Other phytoliths identified in the coarse fraction include dicot plates, sclereids, and round scalloped forms diagnostic to the genus Cucurbita. As these forms are significantly larger than those produced in wild plants, it is suspected that these phytoliths are derived from cultivated squashes or pumpkins rather than the native buffalo gourd Cucurbita foetidissima.

The phytolith assemblage from the fine fraction was also dominated by grasses. Cool climate C3 Festucoideae forms were well represented by keeled, conical, pyramidal, and crenate phytoliths. The Chloridoideae, or bunch grasses, are members of the drier climate $\mathrm{C} 4$ grasses (Buffalo grass and Grama grass types), and are represented by saddle-shaped phytoliths. The Panicoideae group of grasses are represented by Panicoid bilobates and crosses. This group is also a warm climate $\mathrm{C} 4$ grass, and like the Chloridoideae, is well represented in the natural vegetation of south Texas.

Other grass types were also encountered in the San Juan phytolith samples. A distinctive type of bilobate was noted in all of the samples, and is particularly common in the genus Stipa. However, this type also 


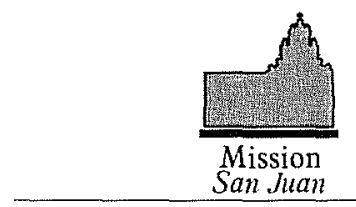

occurs in other genera and a positive identification should not be made. Likewise, generalized bilobates are found in nearly all grasses and cannot safely be assigned to any category.

Domesticated grasses are also represented in the San Juan phytolith assemblage by the occurrence of large, distinctive cross bodies characteristic of Zea mays (maize). Other forms consisting of distinctive elongates and spinulose types are common in some of the domesticated Festucoideae grasses including wheat
(Triticum spp.), oats (Avena spp.), and barley (Hordeum spp.) (Kaplan et al. 1992; Rosen 1992). The domesticated Festucoid grasses are all of an Old World origin, and it is significant to note that although a positive generic identification cannot be assigned to these phytolith types, it is clear that they are derived from non-native, domesticated grasses.

Phytoliths from non-gramineous plants were also present in the assemblage. These include Carex, Cyperus and other non-diagnostic Cyperaceae (all sedges), and the distinctive plates from Celtis (hackberry) fruits.

Table 1-18. San Juan, Phytoliths identified in the eight sediment samples

\begin{tabular}{|c|c|c|c|c|c|c|c|c|}
\hline Taxa & L-3 & $\mathbf{L}-4$ & $\mathbf{L}-5$ & $L-6$ & L-7 & L_-8 & L-10 & L-12 \\
\hline \multicolumn{9}{|l|}{ Coarse Fraction } \\
\hline Bulliform Poaceae & $55(18.2)$ & $76(23.5)$ & $67(21.3)$ & $51(15.4)$ & $37(12.3)$ & $87(21.2)$ & $42(13.2)$ & $58(18.7)$ \\
\hline Poaceae Elongate & $26(8.6)$ & $20(6.2)$ & $16(5.1)$ & $14(4.3)$ & $7(2.3)$ & $34(8.3)$ & $18(5.7)$ & $10(3.2)$ \\
\hline Poaceae Hair/Edge & $37(12.2)$ & $22(6.8)$ & $23(7.3)$ & $19(5.8)$ & $15(5.0)$ & $27(6.6)$ & $27(8.5)$ & $28(9.0)$ \\
\hline Bulliform & $179(59.1)$ & $200(61.9)$ & $205(65.1)$ & $218(67.1)$ & $236(78.7)$ & $256(62.5)$ & $224(70.7)$ & $208(67.1)$ \\
\hline Rod & $5(1.7)$ & $3(0.9)$ & $3(1.0)$ & $21(6.5)$ & $2(0.7)$ & $5(1.2)$ & $6(1.9)$ & $4(1.3)$ \\
\hline Cucurbita & $1(0.3)$ & $1(0.3)$ & $1(0.3)$ & $2(0.6)$ & & & & $1(0.3)$ \\
\hline Dicot Plate & & $1(0.3)$ & & & $3(1.0)$ & $1(0.2)$ & & \\
\hline Sclereid & & & & & & & & $1(0.3)$ \\
\hline TOTAL & $303(100)$ & $323(100)$ & $315(100)$ & $325(100)$ & $300(100)$ & $410(100)$ & $317(100)$ & $310(100)$ \\
\hline \multicolumn{9}{|l|}{ Fine Fraction } \\
\hline Keeled & $11(3.3)$ & $11(3.3)$ & $4(1.2)$ & $10(3.0)$ & $11(3.4)$ & $6(1.9)$ & $12(3.8)$ & $8(2.5)$ \\
\hline Conical & $2(0.6)$ & $6(1.8)$ & $3(0.9)$ & $4(1.2)$ & $3(0.9)$ & $3(0.9)$ & $4(1.3)$ & $2(0.6)$ \\
\hline Pyramidal & $8(2.4)$ & $5(1.5)$ & $6(1.8)$ & $8(2.4)$ & $12(3.7)$ & $3(0.9)$ & $4(1.3)$ & $4(1.2)$ \\
\hline Crenate & $25(7.4)$ & $37(11.0)$ & $13(4.0)$ & $18(5.4)$ & $6(1.8)$ & $13(4.1)$ & $14(4.4)$ & $2(0.6)$ \\
\hline Saddle & $77(22.8)$ & $81(24.2)$ & $66(20.2)$ & $73(22.0)$ & $114(34.8)$ & $86(27.1)$ & $87(27.4)$ & $75(23.4)$ \\
\hline Panicoid B & 117 (34.6) & $88(26.3)$ & $131(40.2)$ & $87(26.2)$ & $81(24.7)$ & $98(30.9)$ & $49(15.5)$ & $143(44.7)$ \\
\hline Cross & $11(3.3)$ & $9(2.7)$ & $16(4.9)$ & $16(4.8)$ & $18(5.5)$ & $9(2.8)$ & $5(1.6)$ & $28(8.8)$ \\
\hline Stipa-type & $3(0.9)$ & $3(0.9)$ & $7(2.1)$ & $6(1.8)$ & $8(2.4)$ & $2(0.6)$ & $42(13.2)$ & $4(1.2)$ \\
\hline Bilobate & $66(19.5)$ & $68(20.3)$ & $61(18.7)$ & $93(28.0)$ & $53(16.2)$ & $85(26.8)$ & $77(24.3)$ & $46(14.4)$ \\
\hline Zea mays & $9(2.7)$ & $2(0.6)$ & $2(0.6)$ & $4(1.2)$ & $2(0.6)$ & $2(0.6)$ & $1(0.3)$ & $6(1.9)$ \\
\hline Cerealea-ty & $8(2.4)$ & $22(6.6)$ & $12(3.7)$ & $7(2.1)$ & $19(5.8)$ & $8(2.5)$ & $22(6.9)$ & $2(0.6)$ \\
\hline Carex & & & $3(0.9)$ & $5(1.5)$ & & & & \\
\hline Cyperus & & $1(0.3)$ & $1(0.3)$ & & $1(0.3)$ & $1(0.3)$ & & \\
\hline Cyperaceae & $1(0.3)$ & $2(0.6)$ & $1(0.3)$ & & & & & \\
\hline Celtis & & & & $1(0.3)$ & & $1(0.3)$ & $1(0.3)$ & \\
\hline TOTAL & $338(100)$ & $335(100)$ & $326(100)$ & $332(100)$ & $328(100)$ & $317(100)$ & $317(100)$ & $320(100)$ \\
\hline
\end{tabular}




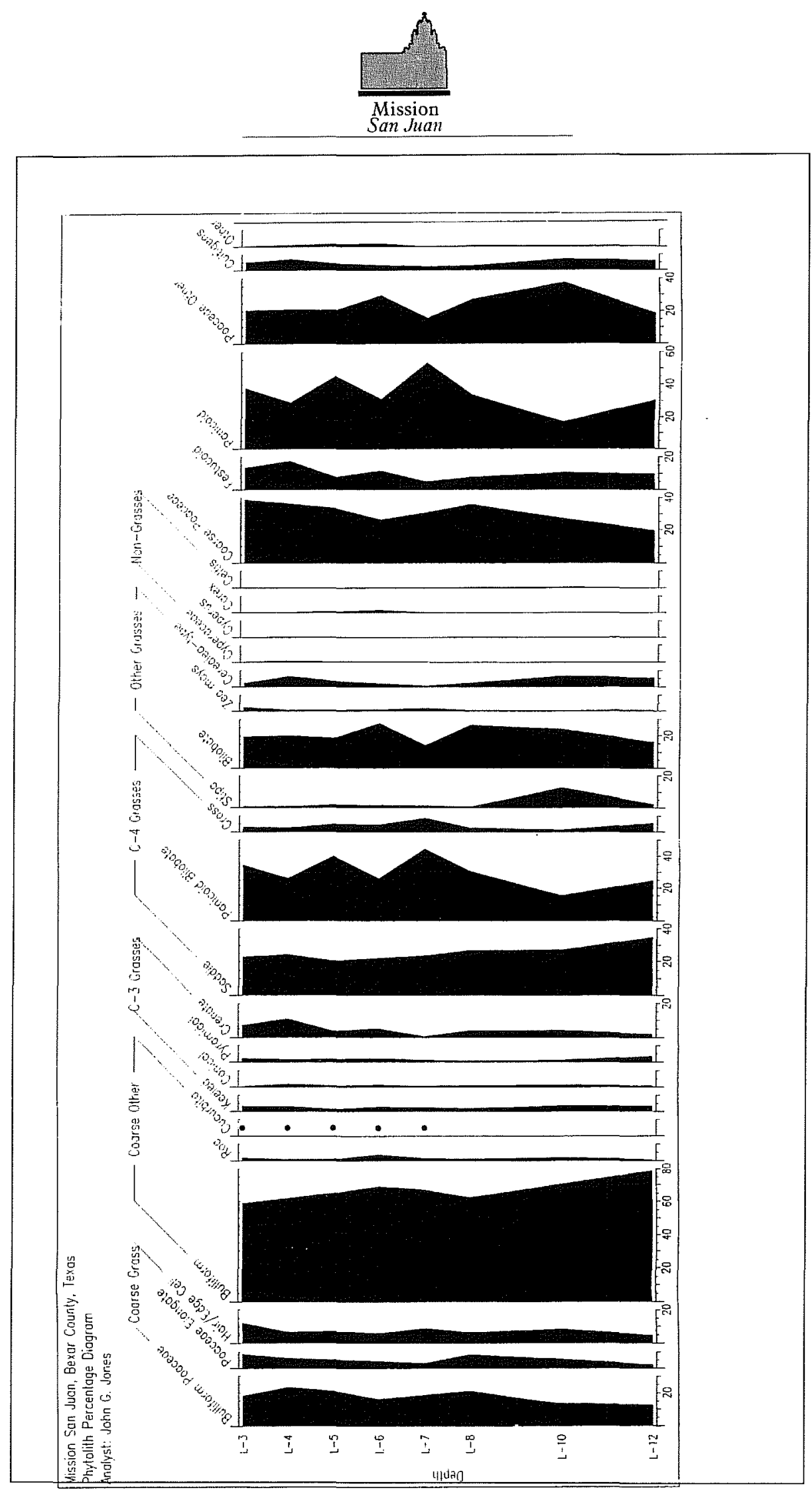

Figure 1-22. San Juan, Phytolith percentage diagram. 


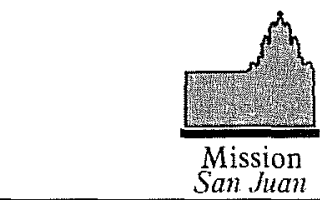

\section{Discussion}

Although the Mission San Juan phytolith assemblage is dominated by non-economic grasses which typify the vegetation in the site area (i.e., Chloridoid saddles, bilobates, and Panicoid bilobates and crosses), much information can be gained regarding the past presence of cultigens in the site area. Domesticated Cucurbita (squash) phytoliths were noted in samples from Levels 3-6 and Level 12. These phytoliths occur in squash pericarp (rind) and peduncles (stems) and indicate that squash was present, perhaps stored in the room in the past. Maize phytoliths are also well represented in the San Juan samples, where large, distinctive cross phytoliths were noted in all levels. Maize cross phytoliths are produced in both leaves and cobs. Again, it seems likely that maize was stored in the room in the past.

Most surprising perhaps, was the abundance of domesticated Festucoid (Cerealea-type) phytoliths encountered in the San Juan samples. Most of the phytoliths compare favorably to forms produced in the husks and glumes of wheat and barley rather than those found in the culms and stalks. These phytoliths would be likely to occur in seed husk or flour samples rather than in animal fodder. Again, this might be in keeping with a granary or food storage area. An alternate explanation for the abundance of cultigen phytoliths in Unit 9 might be that the room served for fodder or silage storage, or as an animal pen. While corn stalks and squash rinds might have been fed to domesticated animals in the past, the presence of Cerealea husk or glume phytoliths argues against this interpretation.

The sample from Level 10 contains a significant amount of Stipa-type grass phytoliths. The reason for the abundance in this level is unclear, but it may have something to do with the floor preparation. Caliche or clay used in preparing the floor may have been brought in from an area dominated by this grass group, or Stipa-type grass stems or leaves may have been brought into this room for some reason. Grasses in the Stipa group are not known to have significant economic value. The variation in this phytolith sample serves to demonstrate that the floor samples probably represent discrete periods and are valuable sampling units.

Phytoliths in the San Juan assemblage deriving from plants other than grasses are probably non-economic in origin. Sedge phytoliths from Carex, Cyperus, and non-diagnostic genera may have been introduced through natural environmental means. As most sedges prefer a wetland or aquatic setting, their numbers are generally highest around bodies of permanent water. It is possible that these phytoliths were introduced with water brought into the room for some purpose. Several Celtis (hackberry) phytoliths were also present in the San Juan samples. This tree is a common component of the Bexar County vegetation today, and was probably equally abundant in the past. Little significance is attached to the presence of these phytoliths in the floor samples.

\section{Summary}

Eight phytolith samples representing eight different floors of Unit 9 at Mission San Juan were examined. Well-preserved phytoliths were observed in all of the samples, and extended counts were made. The assemblages were dominated by local grasses including $\mathrm{C} 4$ Chloridoideae bunch grass (Buffalo grass and Grama grass) and Panicoideae forms, and lesser amounts of Festucoideae forms. Most significant was the presence of large quantities of phytoliths deriving from economic cultigens. Phytoliths from domesticated Cucurbita were noted in samples from five different levels suggesting that squash or pumpkin may have been stored in the room during Colonial times. Phytoliths from Zea mays were found in all levels, as were husk or glume phytoliths from Old World cereal grains, probably from wheat. This phytolith signature suggests that the room may have long served as a granary or food preparation area. Future research in this area should consider the potential value of phytolith analysis of historic sediment. 


\section{Summary and Recommendation}

\author{
Mission San Juan
}

Archaeological investigations conducted by CAR personnel at Mission San Juan Capistrano, October and November, 1998, involved excavation of ten 1 x 1-m units and 12 shovel tests. These investigations were conducted for the purpose of establishing if intact cultural materials would be impacted by the placement of a utilities trench along the outside of the western side of the mission compound.

Units 1, 2,3, 9 and 10, all located to the west of the present-day chapel (Room 17) encountered evidence of previously existing building or buildings. While Units 1,2,3, and 10 exposed remains of wall foundations, Unit 9 revealed a series of Colonial period flooring episodes. This indicates that this area of the mission has had a long history of use. The oxidizable carbon ratio (OCR) dating procedure used to date the strata from Unit 9 offers further confirmation of this long history.

Previous attempts to correlate between the known architecture and the historical documentation of the mission have seemingly resulted in a "proving ground" for each room reported in the historical documentation. Taking into account, the thinking that Colonial period procedures used by those recording descriptions and dimensions of the compound were often not identical from one recorder to the next, the match between the documentation and the archaeologically recorded structures appears to be a reasonable fit. The new data on walls and floors revealed here, west of the known structures, does not seem to be accounted for in the Colonial documentation.

Because of the ephemeral nature of this new data it is not possible to determine how these walls and floors articulated with the other structures of the mission. Further investigation would be required to clarify this relationship. Based on results from the phytolith analysis, it can be proposed that, at least, a portion of the remnants found near Unit 9 were used for food storage. Additionally, the Colonial period wall encountered in Unit 8 is not accounted for in the current assignment of room designations. This wall is also west of the previously postulated western extent of the mission compound. The feature appears to be the intersection of a north-south oriented wall with an east-west oriented wall, which indicates, perhaps, the presence of another room or series of rooms. This wall was not encountered in any other test unit and further investigations would be required to determine the exact nature of this feature.

As a result of the present investigation, it was recommended that the proposed underground utility trench not be placed on the projected alignment. It is additionally recommended that no trenching or other intrusive work be conducted in the research area without prior archaeological work designed to determine the extent of these newly discovered features. In the case of overhead utility poles, it is recommended that each hole be excavated to sterile soil by qualified archaeological personnel to ensure that cultural remains will not be adversely impacted.

\section{Eventual Development}

As a result of the archaeological investigations and the recommendations of the archaeologist, CPS decided to abandon the original plan to bury the utility lines. Instead, they were installed on overhead utility poles through the sensitive area. 


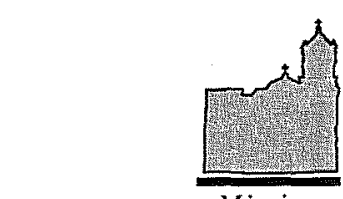

Mission

San José

\section{Introduction}

In January of 1999, personnel from the Center for Archaeological Research (CAR), The University of Texas at San Antonio (UTSA) conducted archaeological testing at Mission San José y San Miguel de Aguayo. The mission is located approximately seven miles south of downtown San Antonio and is one of four missions included in the San Antonio Missions National Historical Park, as state archaeological site trinomial number 41BX3 (Figure 2-1).

The work, which included shovel testing in sensitive areas within the compound and monitoring of trenching for a utility line in less sensitive areas, was conducted under a contract with the city of San Antonio as part of the City Public Service Mission Trails Underground Conversion project. The purpose of these investigations was to determine if intact Spanish Colonial deposits would be impacted by trenching activities. The utility trench was to enter the San José compound in two locations, and to run outside of the mission along San José Drive (Figure 2-2). On January 22, 1999 two staff archaeologists from CAR began the testing portion of the project at the site.

\section{Historic Background}

Mission San José was founded on February 23, 1720 along the east bank of the San Antonio river (Figure 2-1) possibly in the vicinity of the present-day site of Mission Concepción. It is believed that the mission was moved to its current location on the west side of the river the following year (Ivey et al. 1990:107). During the ensuing seventy years a granary, a friary, stone Native quarters, and a stone church were constructed (Habig 1968). The mission was completely enclosed by a stone wall in 1789 with four bastions and six gates noted.

The Native population of the mission fell into decline toward the end of the eighteenth century, and by 1791 the number of permanent residents at the mission had dropped to only 106 Native inhabitants. Population continued to decline and at the time of secularization in 1794, only the ninety-three individuals left were recipients of the mission property as it was divided. By the completion of secularization in 1824, most of the houses that made up the Native quarters had deteriorated into ruins. During the mid-nineteenth century many of the homes in the quarters had been replaced by small frame houses. An aerial photograph of the mission compound taken in ca. 1931 shows several of the frame structures still standing, as well as segments of the ruined walls of the quarters (Figure 2-3). Until the 1960 s, houses continued to be constructed by private individuals on the properties immediately adjacent the mission walls.

\section{Previous Investigations}

Mission San José, often referred to as the "Queen of the Missions," was among the first of the missions to see total restoration efforts. These efforts, which began in the granary area in November of 1932 , included the excavation of $4,000 \mathrm{cu}$. yds. of soil during ensuing work conducted to locate the foundations (Thurber et al. 1993:95). Much of the work was carried out under the direction of Harvey P. Smith under the Civil Works Administration (CWA) from 1933 to 1935 . Unfortunately, only a brief description of this work, compiled by Smith in 1936, is known to exist (Thurber et al. 1993:95).

In 1968, monitoring was conducted by Mardith Schuetz (1970) of the Witte Museum on trenching activities associated with the installation of a sprinkler system at the mission. The trenches, which were cut to a depth of ca. 12 inches, extended throughout the interior of the mission, and along the outside walls parallel to the north, south, and west sides of the mission. The trenches exposed several buried foundations within the interior. The details of the monitoring consist primarily of an artifact inventory and brief descriptions of the features which were uncovered by the trenching activities. 


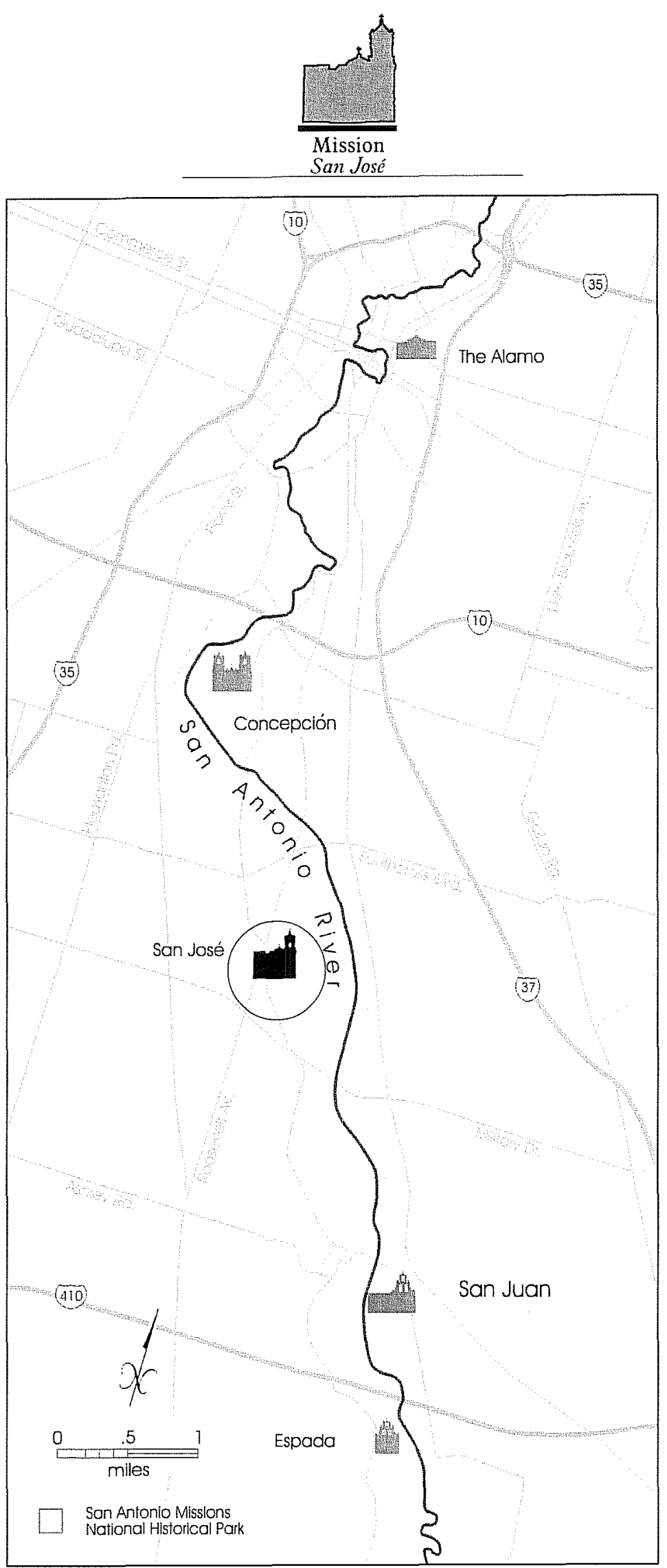

Figure 2-1. The five San Antonio Missions with Mission San José y San Miguel de Aguayo highlighted. 


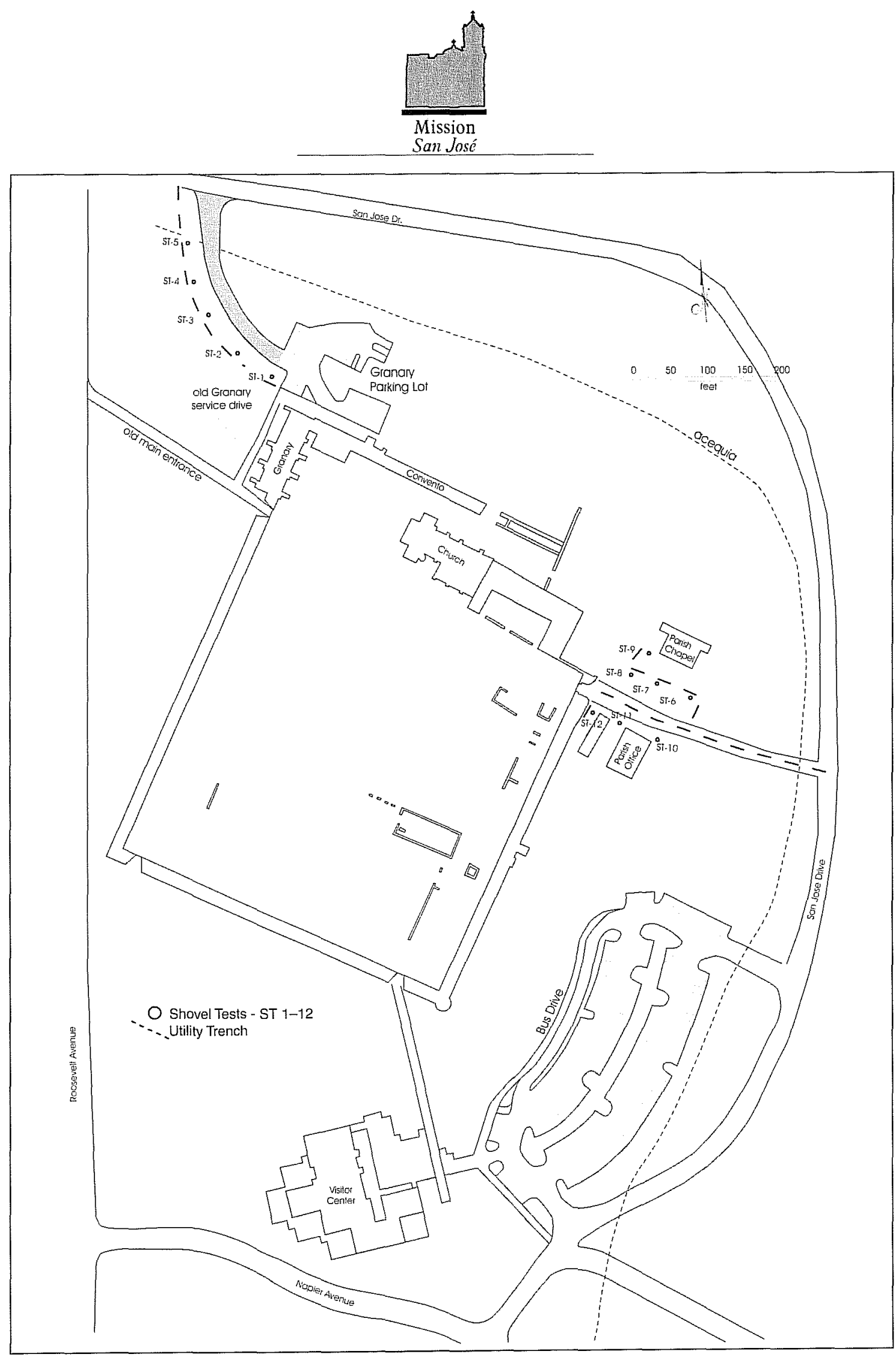

Figure 2-2. Map of Mission San José compound indicating Shovel Tests (1-12) and Utility trench. 


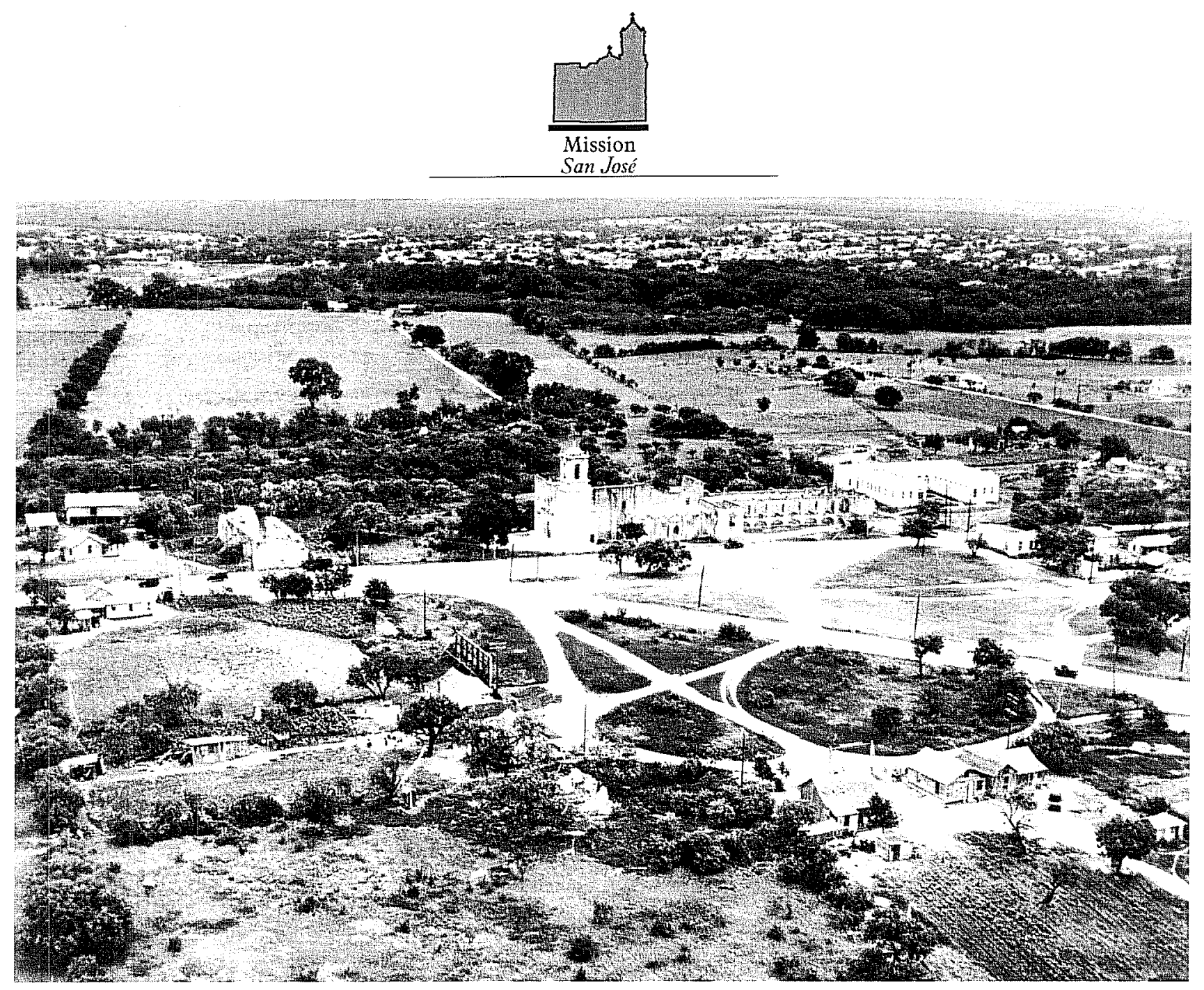

Figure 2-3. Aerial photograph of the Mission San José compound ca. 1930s.

A 1970 report prepared by Daniel Fox, for the Texas Historical Survey Committee, summarizes several monitoring and excavation projects conducted in 1969 and 1970 (Fox 1970). The summary includes descriptions of the monitoring of a sewer line trench placed parallel to and north of the north wall of the mission. Test excavations consisting of three $2 \times 2-m$ test units were conducted prior to trenching and monitoring activities in connection with an electrical line trench dug just north of the church. Monitoring activities also included a drainage trench cut $30 \mathrm{~cm}$ wide and $40 \mathrm{~cm}$ deep for a pipe that carries water from the church entrance patio to a drain east of the north room block. Excavations reported in the summary also include a $2.5 \times 3-\mathrm{m}$ test pit placed north of the church where a persimmon tree was to be planted. In the report, plan maps and profiles are provided for each of the four excavation units.

In 1974, John Clark (1978) of the Texas Historical Commission (THC) conducted investigations around the perimeters of several buildings at the mission to study the effects of climatic conditions on the architectural integrity of the major structures. These investigations included excavation of three units abutting the exterior walls of the chapel and one unit placed along the outside of the east wall at the southeast corner of the compound. Clark suggested that Colonial period occupation levels would be encountered at a depth of ca. 15 inches below the modern surface (Clark 1978). 


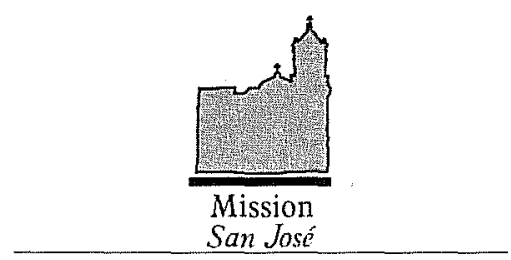

Wayne Roberson and Thomas Medlin (1976) conducted additional work at the mission in 1974. This work was performed in advance of the modifications scheduled for Rooms 31, 32, and 33, located along the west wall at the southwest corner of the compound. These rooms were to be converted into a new office and sanitary facilities within the mission compound. Investigations included the removal of Works Progress Administration (WPA) reconstruction backfill from inside the rooms and excavation of the complete perimeter of each room where new construction might contact buried deposits. Based on the discovery of a series of post-holes inside the east wall of Room 31, Roberson and Medlin concluded that the mission period wall had been built against the outside of a wooden post (jacal) wall of the original Native quarters. Work continued in the southwest corner of the compound in 1976 when Roberson and Medlin (1976) returned to excavate two units in connection with the installation of a new gate in this area.

In 1979, Clark returned with Elton Prewitt to conduct testing operations prior to the installation of a French drain along the west wall of the granary (Clark and Prewitt 1979:iii). Five $0.5 \times 1-\mathrm{m}$ units were placed along the proposed route of the drain and one $0.5 \times 1$ $\mathrm{m}$ unit was placed ca. 37 feet away, at the outer edge of the dispersion field. Over 1,800 faunal remains and 1,300 artifacts were recovered with seven features including:
a) A wall;
b) A flagstone floor remnant;
c) Four trash pits; and
d) A lime-filled trench.

Finding this evidence of Spanish Colonial cultural remains prompted reconsideration of the original plan to place a drain in this area.

James Bradford and Diane Traylor of the Southwest Cultural Resources Center conducted archaeological investigations in 1981 in connection with proposed stabilization work on the Arbor at San José. The purpose of the project was "to define the nature of the reconstructed foundations or features which might underlie the project area" (Bradford and Traylor 1981). Their findings cast some doubt on the accuracy of the WPA placement of reconstructed walls, as their research uncovered several previously unknown Colonial foundations.

During renovations inside the Church in 1981, a wooden platform was removed revealing a matrix of loose earth (Nickels and Fox 1999). CAR was contracted by Ford, Powell and Carson to investigate this area before restoration work commenced. Four excavation units measuring $50^{\prime \prime} \times 77^{\prime \prime}$ were placed within the Sacristy area of the Church. Information regarding the original construction of the Sacristy was recovered as well as over 100 pieces of highly fragmentary human skeletal remains (Nickels and Fox 1999).

When plans for improvements to Napier Avenue were developed in 1984, archaeologists from the Texas State Department of Highways and Public Transportation (SDHPT) conducted investigations in the roadbed, as road grading operations had exposed several features (Henderson and Clark 1984). Three features were encountered during the course of these investigations:

1) A series of post-holes uncovered just outside the south wall. (It was conjectured that these features were from a Colonial period corral, consisting of posts set approximately one meter apart.);

2) A segment of the acequia located to the southeast of the mission was encountered; and

3) A human burial of indeterminate date was also located on the west bank of the acequia.

Hafernik and Fox from CAR conducted additional investigations in 1984. These investigations included the excavation of a backhoe trench outside the west wall of the mission prior to the installation of a proposed sewer line. A stone-lined well, approximately five feet in diameter was uncovered and recorded. The well, apparently, dates to sometime after secularization of the mission ca. 1893, and continued in use, 


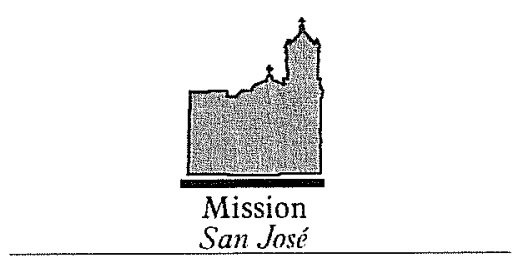

first as a well and later as a privy pit until ca. 1940 (Hafernik and Fox 1984). Mitigation was the course of action recommended by CAR archaeologists before the installation of the sewer line proceeded.

In 1985, CAR archaeologists returned again to excavate one half of the well under an additional contract (Fox 1987). A total of 26 levels were excavated in the well to a final depth of $510 \mathrm{~cm}$ below surface. A mixture of eighteenth, nineteenth, and twentieth century artifacts found inside the well are attributed to a Colonial period blacksmith's workshop thought to have been located outside the west wall of the mission, and to a residential privy which had been set over the well.

Plans to construct a new Visitors' Center and adjoining parking area prompted the initiation of a project in 1991 which was aimed at locating and identifying the acequia madre where it ran between the east wall of the mission and San José Drive, and to relocate another smaller acequia which had been located in the area in 1981. Archival research in conjunction with several backhoe trenches securely located and documented both acequias (Fox and Cox 1991). It was concluded that the smaller acequia was a lateral diverted from the acequia madre in order to irrigate the fields outside the east wall of the mission.

Additional research addressing the impact of the planned Visitors' Center and associated improvements was conducted by CAR during the spring and summer of 1993. Backhoe trenching, shovel testing, and unit excavations were conducted in areas of proposed impact (Hard et al. 1995). Additionally, shovel testing was conducted within the mission compound to gather information for the future correction of drainage problems. Several incongruities with prior interpretations were observed during the course of this project. Apparently the 1935 reconstruction, which placed a gate in the southeast corner of the compound, was in error as excavations conducted revealed hints of a wall running across the area. Additionally, the bastion adjacent to the southeast corner was also proven to have no historical basis, and was apparently merely a product of the 1935 reconstruction.

More investigations were carried out near the southeast corner of the mission compound in 1996 in association with the proposed storm drainage line which was to be routed south out of the southeast gate of the compound (Tennis 1998). These investigations included one $6 \times 6$ - $\mathrm{ft}$ excavation unit, eight $4 \times 4$-ft excavation units, two irregularly shaped excavation units, 9 shovel tests and 3 backhoe trenches. As a result of these investigations, two sections of wall foundation dating to the Colonial period were exposed and documented. These foundation footings represented the interior and exterior walls of a room block much like the existing, reconstructed Native quarters which occupy the remainder of the south wall. These data are interpreted as conclusive evidence that the 1935 reconstruction, which placed a gateway in the area, was in error (Tennis 1998).

CAR archaeologists, Tomka and Fox returned to San José in 1997 to expose foundation footings along the outside and inside walls of the Native quarters for the purpose of investigating the nature of structural deterioration. Twenty $3 \times 3-\mathrm{ft}$ excavation units and one $1 \times 1$ - $\mathrm{ft}$ unit were executed during this project. The evidence gathered from these investigations added to the sentiment that the 1935 WPA reconstruction had placed walls where no previous Colonial period walls existed (Tomka and Fox 1998).

In February 1998, CAR was contracted to conduct further investigations in the southeast corner on the outside of the mission compound. This archaeological investigation was performed in association with the planned installation of three catchment basins (Tomka and Fox 1999). Twenty-seven $3 \times 3$-ft excavation units were executed along the south wall of the compound. A large quantity of faunal remains were encountered, and the continuous nature of the deposit suggested that a midden was possibly in this area prior to the construction of the mission wall. 


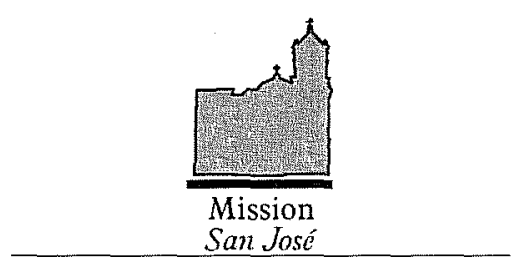

The latest work conducted at Mission San José, in the vicinity of the southeast gate was undertaken in June and late July of 1998, when CAR personnel performed a series of excavations outside the south wall and within Room 54 adjacent the western corner of the southeast gate of the mission. These excavations were undertaken to mitigate the impact underpinning efforts would have at the southwest corner of the southeast gate of the mission (Tomka et al. 1999). Three main conclusions were drawn from this work:

1) A large portion of the soils and cultural materials found immediately adjacent the south wall of the mission have been disturbed by Civil Works Authority (CWA) efforts to relocate the Colonial foundation and outer walls of the mission;

2) Much of the cultural material-bearing matrix found along the south wall of the mission on the inside of Room 54 is also disturbed to a depth of approximately 19 inches bs; and

3) A Colonial living surface exists immediately below the disturbed zone in portions of the interior of Room 54 and under the southeast gate.

\section{Methodology}

Based on the proposed impact to specific areas within the grounds of the San José mission, a data recovery program was designed to investigate the potential for encountering intact cultural remains. Because much of the area to be impacted outside the compound walls had previously been disturbed by the construction of parking areas, service drives, and parish buildings, a shovel testing and monitoring program was designed.

The testing included a series of 12 Shovel Tests (STs) which were to be excavated on mission property, while the monitoring portion was to be conducted visually on utility trenching activities (Figure 2-2).

Shovel tests 1-5 were placed along the western side of the existing service drive located in the northwest corner of the mission grounds. These tests were num- bered consecutively going northward and were spaced at 20-m intervals. Shovel tests 6-9 were placed immediately to the south of the Parish Chapel on the east side of the mission grounds and spaced at $10-\mathrm{m}$ intervals. Shovel tests 10 and 11 were placed directly to the north of the Parish office. Shovel test 12 was placed adjacent and outside of the eastern wall of the compound on the south side of the east-wall gate. These units were excavated in $10 \mathrm{~cm}$ arbitrary levels to a depth of $50 \mathrm{~cm}$ below surface and all soil was screened through 1/4-inch wire mesh. Brief descriptions of soils encountered were recorded and artifact counts were documented on shovel test forms.

\section{Results}

Shovel testing resulted in the recovery of a variety of both Colonial and post-Colonial artifacts including: animal bone; chipped stone; metal; ceramics; and glass (Table 2-1). Shovel tests 1-5, revealed several areas of heavy disturbance, especially in the upper $30 \mathrm{~cm}$, and some areas which appeared to remain relatively intact, predominantly in the lower $20 \mathrm{~cm}$ (Table 2-2). In the top layer of Shovel test 4, a thin layer of midden material consisting of a mix of early-to-mid- twentieth century artifacts was encountered. Monitoring of the trench which cut through this area confirmed the presence/existence of a modern trash midden at this location (Figure 2-2). The materials recovered indicate that it was probably used from around the turn of the twentieth century to possibly ca. 1960 . The early component of this trash midden probably relates to a farmstead that was located in the immediate vicinity and can be seen in a ca. 1931 aerial photo (Figure 2-3). Several nearby buildings postdate the farmstead and probably account for the more recent materials recovered in the midden.

Shovel tests 6-9, revealed what appeared to be sterile fill to a depth of $50 \mathrm{~cm}$ below surface. Shovel tests 10-11 yielded a few Colonial period artifacts in a heavily disturbed context. The disturbances appear to 


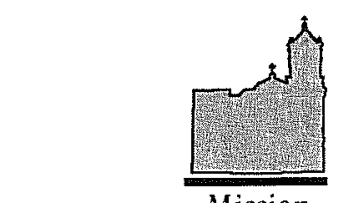

Mission

San José

Table 2-1. Summary of material recovered by shovel test

\begin{tabular}{|c|c|c|c|c|c|c|c|c|c|}
\hline Shovel Test & Ceramics & Glass & Bone & Metal & Plastic & Constr. & Buttons & Toys & TOTALS \\
\hline 1 & 5 & 2 & 13 & 0 & 1 & 1 & 0 & 0 & 22 \\
\hline 2 & 1 & 10 & 3 & 4 & 0 & 5 & 0 & 0 & 23 \\
\hline 3 & 0 & 1 & 0 & 0 & 0 & 1 & 0 & 0 & 2 \\
\hline 4 & 0 & 4 & 4 & 3 & 3 & 4 & 3 & 3 & 24 \\
\hline 5 & 0 & 0 & 0 & 0 & 0 & 1 & 0 & 0 & 1 \\
6 & 0 & 0 & 0 & 0 & 0 & 1 & 0 & 0 & 1 \\
\hline 7 & 0 & 0 & 0 & 0 & 0 & 0 & 0 & 0 & 0 \\
\hline 8 & 0 & 0 & 0 & 0 & 0 & 0 & 0 & 0 & 0 \\
\hline 9 & 0 & 0 & 0 & 0 & 0 & 0 & 0 & 0 & 0 \\
10 & 0 & 0 & 0 & 0 & 0 & 0 & 0 & 0 & 0 \\
11 & 1 & 1 & 5 & 1 & 0 & 0 & 0 & 0 & 8 \\
\hline 12 & 4 & 1 & 38 & 0 & 0 & 3 & 0 & 0 & 46 \\
\hline Totals & $\mathbf{1 1}$ & $\mathbf{1 9}$ & $\mathbf{6 3}$ & $\mathbf{8}$ & $\mathbf{4}$ & $\mathbf{1 6}$ & $\mathbf{3}$ & $\mathbf{3}$ & $\mathbf{1 2 7}$ \\
\hline
\end{tabular}

Table 2-2. Summary of material recovered by level

\begin{tabular}{|c|c|c|c|c|c|c|c|c|c|}
\hline Level & Ceramics & Glass & Bone & Metal & Plastic & Constr. & Buttons & Toys & TOTALS \\
\hline $1(0-10 \mathrm{~cm})$ & 4 & 7 & 3 & 0 & 1 & 8 & 3 & 1 & 27 \\
\hline $2(10-20 \mathrm{~cm})$ & 0 & 11 & 15 & 7 & 3 & 5 & 0 & 2 & 43 \\
$3(20-30 \mathrm{~cm})$ & 4 & 1 & 41 & 1 & 0 & 2 & 0 & 0 & 49 \\
$4(30-40 \mathrm{~cm})$ & 2 & 0 & 4 & 0 & 0 & 1 & 0 & 0 & 7 \\
\hline $5(40-50 \mathrm{~cm})$ & 1 & 0 & 0 & 0 & 0 & 0 & 0 & 0 & 1 \\
\hline Totals & $\mathbf{1 1}$ & $\mathbf{1 9}$ & $\mathbf{6 3}$ & $\mathbf{8}$ & 4 & $\mathbf{1 6}$ & $\mathbf{3}$ & $\mathbf{3}$ & $\mathbf{1 2 7}$ \\
\hline
\end{tabular}

be related to the construction of the Parish offices and associated service drive found nearby. Shovel test 12 encountered a possible Colonial period bone midden and several Colonial period ceramics in an intact deposit between $20-30 \mathrm{~cm}$ below surface. No architectural features were observed in association with any of the shovel testing or monitoring procedures.

\section{Summary and Recommendation}

As a result of these investigations it appears that an early-to-mid- twentieth century midden was identified in the northwestern corner of the mission grounds (ST 4 and ST 5). This midden can tentatively be attributed to several houses, which once stood in the area and were either torn down or moved off the property sometime after ca. 1960. No Colonial period architectural features were encountered in association with testing in this area and the midden feature did not warrant the relocation of the trenches in this vicinity. The shovel tests in front of the Parish Chapel revealed that the terrain in this area had been artificially built up using sterile soil brought in from an outside source.

Shovel tests 10 and 11 in front of the Parish offices revealed heavily disturbed matrix associated with the construction of both the offices and the service drive located to the north of the offices. Shovel test $12 \mathrm{did}$ locate an intact Colonial period concentration of animal bone, probably associated with an early midden at the mission. No architectural features were found in association with this deposit and it was determined that trenching in this area would have no adverse affect on the Colonial period remains. Because of the sensitive nature of Colonial deposits in and around the Mission San José compound, it is recommended that if any additional trenching is required, archaeological investigations should precede these activities. 


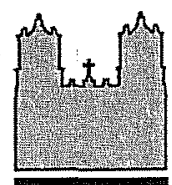

Mission

Concepción

\section{Introduction}

by Barbara A. Meissner

On November 11, 1998, the Center for Archaeological Research (CAR), The University of Texas at San Antonio (UTSA) contracted with City Public Service (CPS) of the city of San Antonio, Texas, to provide archaeological monitoring for the Mission Trails Underground Conversion (MTUC) Project. In addition, CAR contracted to provide archaeological testing of any cultural resources unexpectedly discovered during the course of the project, to assess the age, context, condition, and significance of the resource, and to provide recommendations for further treatment of any archaeological resources eligible for inclusion in the National Register of Historic Places.

On January 26, 1999, during a portion of the MTUC project, as construction workers were excavating to accommodate a new manhole below Felisa Street, just south of the Visitors' Center of Mission Concepción (Figure 3-1 and Figure 3-2), they noticed a large number of animal bones in the backdirt. As required, digging stopped and telephone calls were placed to the Historic Preservation Office of the city of San Antonio, to the Texas Historical Commission (THC), and to CAR.

The pit was roughly square -about 8 feet $(2.5 \mathrm{~m})$ on a side and was approximately 7 feet $(2.13 \mathrm{~m})$ deep in the northern $2 / 3$ sloping up to approximately 2 feet $(0.61 \mathrm{~m})$ deep in the southern $1 / 3$. Initial examination of the walls of the hole by CAR personnel showed that the construction activities had unintentionally impacted a large feature. The feature appeared to be a deep pit or a portion of an acequia which contained numerous layers of fill. Large numbers of animal bone were visible in the upper part of the northwestern and northeastern profile of the pit (Figure 3-3).

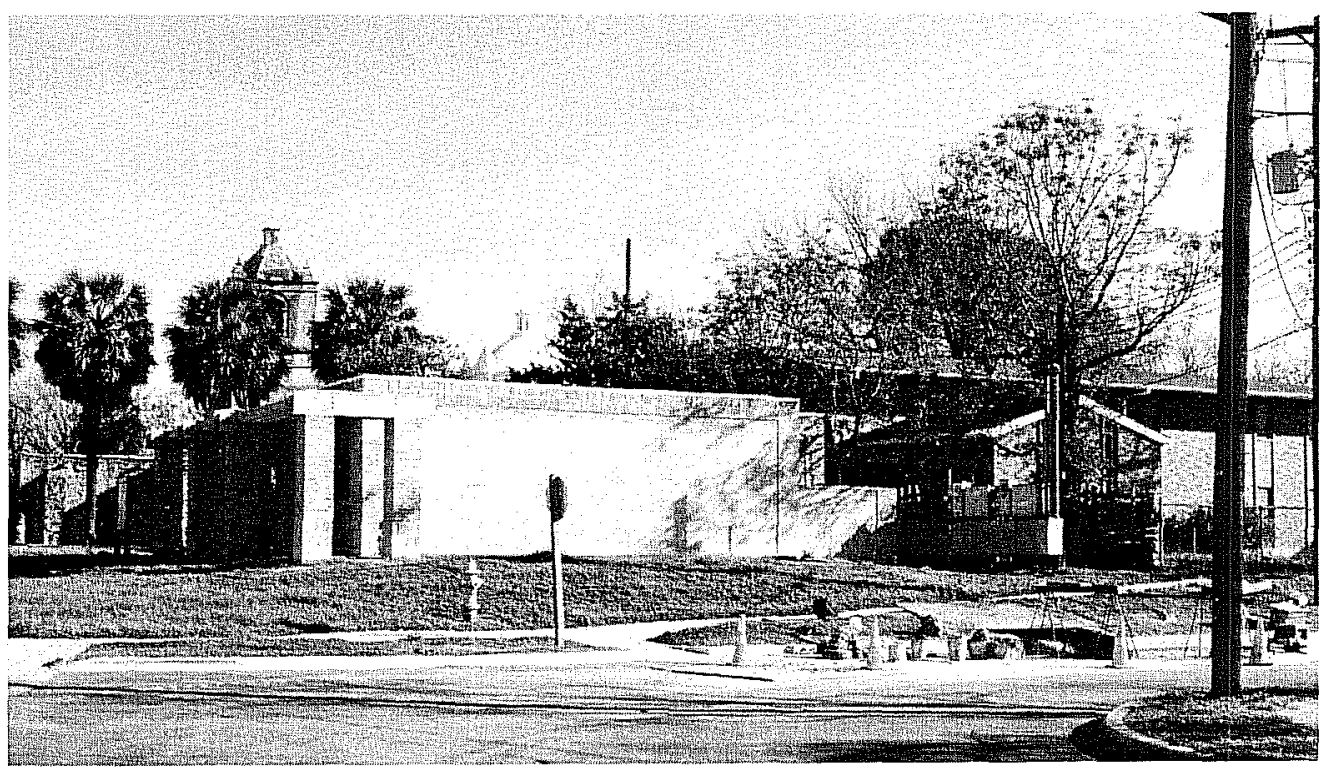

Figure 3-1. Project area (looking northeast): manhole pit shown in lower right, South wall of Visitors 'Center in middle, and a tower of the Mission Church in background. 


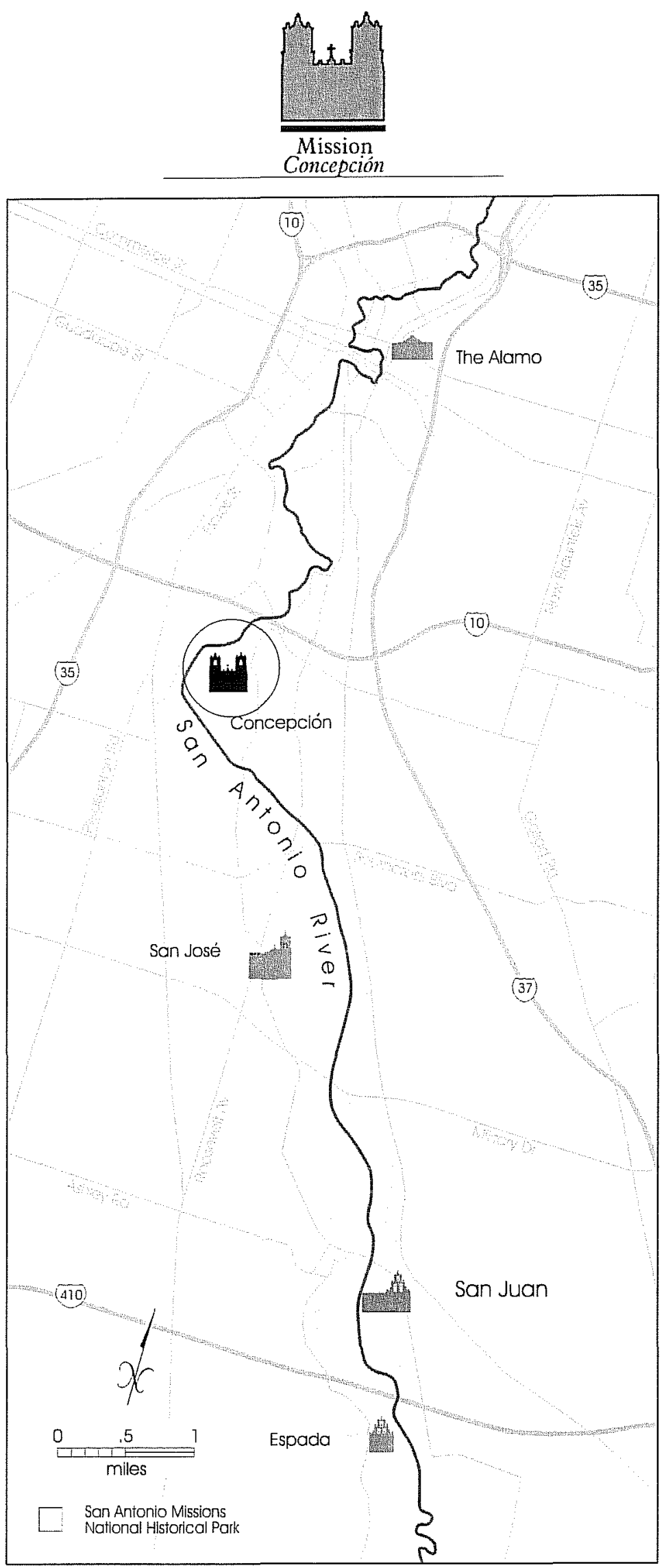

Figure 3-2. The five San Antonio Missions with Mission Nuestra Señora de la Purisima Concepción highlighted. 


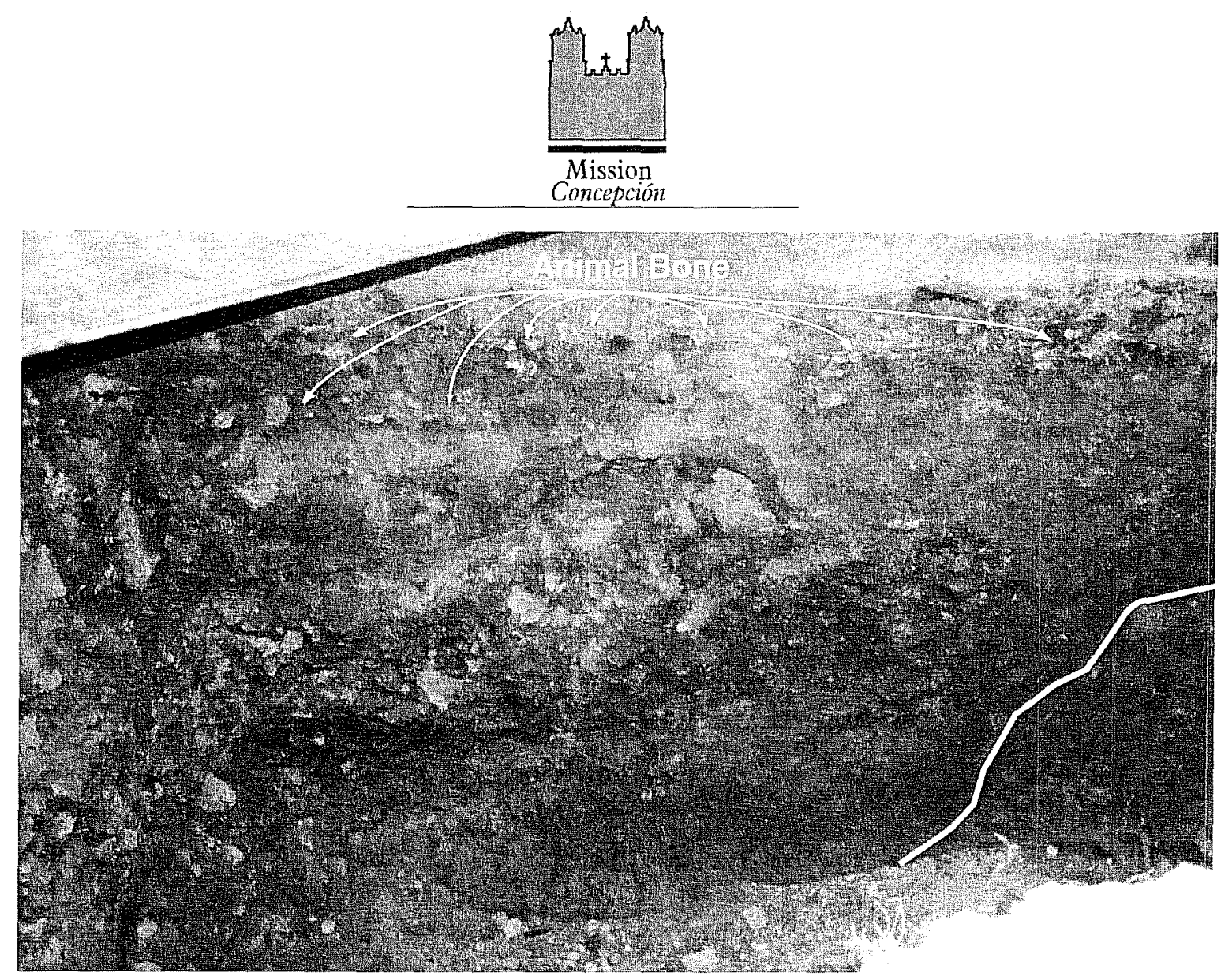

Figure 3-3. Photograph of northeast pit wall, showing numerous layers of fill, and large number of animal bones in upper layer.

Note: Thick white line shows approximate edge of hard-packed caliche.

CPS and CAR, in consultation with Mark Denton of THC, agreed that an archaeological assessment of this feature was necessary. The purpose of the assessment was to:

1) Establish the nature of the feature; and

2) Learn when the feature had been filled, if possible.

To determine this, two $1 \times 1$ meter units would be excavated, one on each side of the pit. If the feature was an acequia backfilled in the late-nineteenth or early-twentieth century, as most acequias in San Antonio had been, CAR would record the feature and CPS would then be able to continue construction of the manhole. If the feature had been filled before ca. 1850 , more units would be required to assess and mitigate any damage that would incur when CPS finished the manhole and dug the trenches for electrical conduits which would lead into and out of it.

Excavation of the initial units determined that the feature was an acequia, and that it had been filled during the Colonial period. Two additional test units were excavated along the line that CPS planned to dig for the electrical conduits leading to the manhole to establish the east and west boundaries of this feature. Although further work on the acequia was deemed unnecessary, it was agreed that trenching along the western end of Felisa Street, along Mission Road near the mission, and for the installation of a terminal box east of the Visitors' Center would be monitored by a staff archaeologist from CAR. Results of the monitoring are presented in Appendix A (Concepción). 


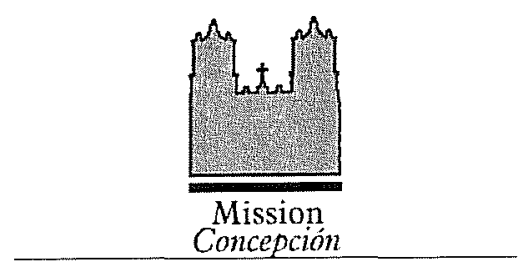

\section{Historic Background}

I. Waynne Cox and Barbara A. Meissner

\section{The Early Habitations}

There is good reason to believe that the Mission Concepción site was used by the Spanish prior to the establishment of that mission in 1731. Current research indicates that this site may have been occupied by Mission San José y San Miguel de Aguayo at its initial founding and was probably the site of the short-lived Mission San Francisco Xavier de Nájera (Ivey and Fox 1999: 45-46). The Aguayo map (Figure 3-4), made shortly after the founding of San José, clearly shows the first location of this mission on the east bank of the river, near its confluence with San Pedro Creek, i.e., at or near the current location of Mission Concepción. The evidence for the whereabouts of Mission Xavier is more clear-cut, with explicit documentation on its location.

In 1719 , the French and their Native American allies forced the Spanish missionaries to temporarily abandon their missions in east Texas. During this time the mission refugees stayed for ca. a year and a half at Mission San Antonio de Valero (now called the Alamo). One of the refugees, Fray Antonio Margil, decided to found a new mission in the San Antonio valley for the Native groups who wanted to enter a mission, but did not integrate well with those groups already at Mission San Antonio, which had been founded some 18 months before (Habig 1968a: 83).

On February 23, 1720, Lieutenant General Captain Juan Valdéz, accompanied by Father Margil and an official party, arrived at an area...

“...where water can be drained from the San

Antonio River to irrigate the land" and

" ...went down river following the direction where the irrigation ditch is to be"

(Valdéz 1968 [1720]).
They selected a site where...

“...the land offered such rich pastures and plentiful woods for beams, quarry stones, and firewood.

There are excellent exits and entrances along the river for the cattle, sheep, goats and horses"

(Valdéz 1968[1720]).

Having satisfied all involved that this was a suitable location, Mission San José y San Miguel de Aguayo was established (Valdéz 1968 [1720]:32-35). The location of this first site is not recorded, but Fray Espinosa reported that it was located on the east side of the river, as is shown by Aguayo's map (Habig 1968b:29-30). The map does show Mission San José situated near the confluence of San Pedro Creek (Figure 3-4). The mission was moved to a new site on the west bank of the river prior to 1727 , possibly as early as 1722 (Ivey and Fox 1999:45).

In 1722, another mission, San Xavier de Nájera, was established one league ( 2.63 miles) south of Mission San Antonio de Valero. It was abandoned about 1726 , due to a lack of interest by the Natives for whom it had been established (Ivey and Fox 1999:45). The few documents available concerning this abortive effort do not state the location, however, the founding documents of Mission Concepción explicitly state that the new mission was located on the same site as the failed Mission San Xavier (Almazán 1731:20).

\section{Mission Concepción}

In 1730, Spain decided to remove three missions from east Texas. They were first moved to a site on the Colorado River, but the next year were moved again to the San Antonio valley (Habig 1968a:124). One of these missions was renamed Nuestra Señora de la Purísima Concepción. By 1739, there were 250 Native inhabitants living at the mission, though an epidemic that year cut the population in half (Habig 1968a:126). A report to the founding college in Querétero in 1745, indicated that there were 207 


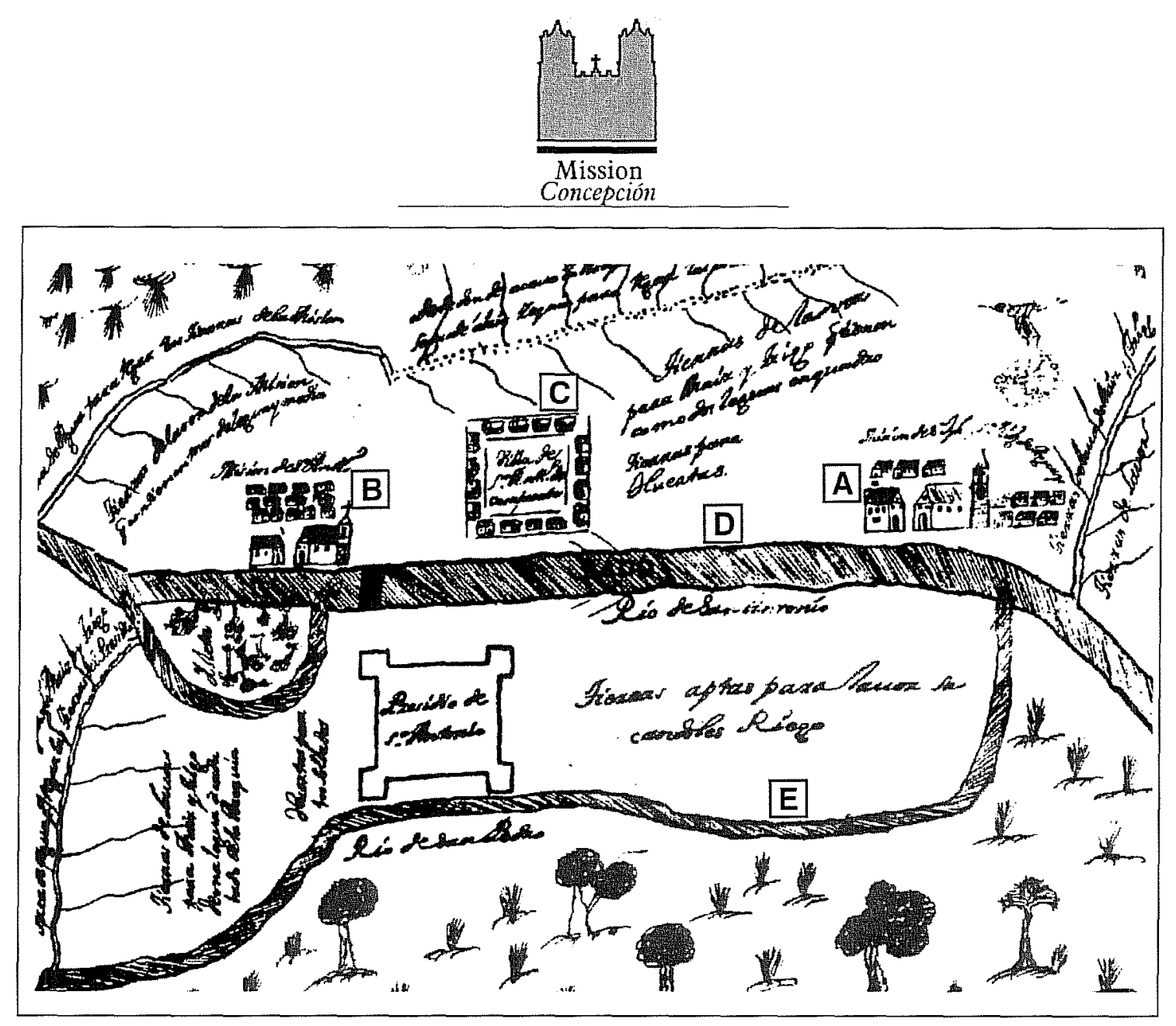

Figure 3-4. A portion of the Aguayo map, drawn in 1729: A) Mission San José; B) Mission San Antonio (the Alamo); C) Villa San Fernando (San Antonio); D) San Antonio River; E) San Pedro Creek.

neophytes living within the mission compound at Concepción. Inside the stone walls, made necessary by constant attacks by hostile Native groups, were a church, a convento, a granary, and several other buildings, in addition to the jacales (mud-plastered wooden huts) which housed the Native inhabitants. At that time a new stone church was under construction, and by the time of the next major report in 1756 , the church had been completed.

During the next four decades the work of the missionaries continued. In 1772, the College of Zacatecas, which had control of Mission San José, was given authority over all missions in San Antonio. The first major report after this, in 1777 , indicated that the Native population was declining. By 1789 , there were only 71 neophytes still living at the mission. In 1794 , at the time of partial secularization, there were only
38 living at Concepción (Habig 1968a:141). The lands of the mission were divided among them, but during the following few years a number of Spanish moved into the old mission, and eventually by 1809 they outnumbered the Native occupants living at the mission (Habig 1968a:143).

In 1813, when revolutionary Bernardo Gutiérrez led his army to San Antonio, they made the mission grounds their headquarters (Habig 1968a:144). After 1819 , mass was no longer being said at the Church. In 1831 , the lands around the mission that had not yet been sold, as well as all the remaining buildings except the church, were sold at auction (Habig 1968a:147). Although people continued to live nearby and work the fields, the mission was nearly forgotten. By 1850 , only the Church itself remained intact, but it was being used as a stable by local cattle owners. 


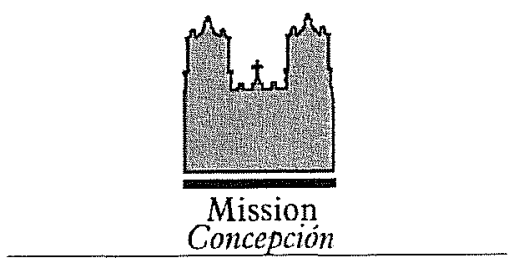

In 1859, the Bishop gave the Church to the Brothers of Mary. They restored it, purchased some of the surrounding lands, and in 1861 the Church was re-consecrated (Habig 1968a:149). Though only remnants of the old mission compound are visible today; the Church still stands and has been active as a parish since re-consecration.

\section{The Concepción Acequia}

The exact locations of the acequias built for Missions San José and San Xavier, if indeed they were both located at this site, are not known. However, the main channel was almost surely utilized as the acequia for the new Mission Concepción when it was established on the site in 1731 and was probably a major factor in the selection of the location. The traces of an acequia located near the quarry that were exposed by THC in 1971 and 1972, further examined by investigations of the National Park Service (NPS) in 1982 most likely stem from the initial construction (Scurlock and Fox 1977, Ivey and Fox 1999: 25). Ceramics, recovered during excavations at these locations, suggest a pre-1730 Spanish habitation (Ivey and Fox 1999:19).

The Concepción, or Pajalache, acequia channel began on the east side of the river at a large dam that spanned a point just above the town's major ford at Presa (Spanish for dam) Street. Because the entry point was at "La Villita" (the little village), one of the highest points in the downtown area, it required a massive cut to initiate a downward flow. The Concepción acequia was referred to as the "largest of the ditches", so large, in fact, it was reported that the fathers kept a boat on it to attend to its cleaning (Corner 1890:44). It was certainly large at the inlet point, for the width was reported as twelve feet (San Antonio Express, October 13, 1913). It progressed southward along the west side of the road to the lower missions, to a point 2500 feet from the intake to where a canoe, or hollow log, transported a later extension of the Alamo acequia madre over the canal on its return to the river. This was later replaced, probably during the mid-1800s, by a "substantial arched stone aqueduct", extant in 1890 (Corner 1890:43). It then progressed along the road to the mission compound where it diverted westward on its return to the river south of the confluence of San Pedro Creek. The deed records during the period after secularization clearly establish that the channel passed to the south of the mission and quarry (Bexar County Deed Records [BCDR], Office of the County Clerk, Bexar County Courthouse, San Antonio, Vol. A2:430).

Initially, the acequia had a total length of approximately 3.3 miles. During its existence a double gate was installed 1.4 miles from the intake, in the vicinity of the Southern Pacific overpass on Roosevelt Avenue, and an eastern branch was constructed to irrigate additional farm lands, adding another two miles to its length. Prior to its abandonment, it consisted of over 7.5 miles of ditches.

In 1869 , the way was finally cleared for the removal of the Concepción dam which had been a major cause of flooding in the downtown river basin. Earlier, when this action was first proposed, it resulted in a court case that had eventually reached the State Supreme Court (Rhodes v. Whitehead, et al. 1903). Once this impediment was cleared, the city took action to remove the old structure that had for so long been the reputed cause of much flooding (City Council Minutes [CCM], Office of the City Secretary, City hall, San Antonio, Vol. C:683). However, this did not end the problems with the old waterway, for the open channel continued to generate complaints.

\footnotetext{
"The ditch is left open beside a public thoroughfare - the earth thrown out and the ditch together occupy two-thirds of the street, of course this condition of the street decreases the value of the property fronting thereon, and its continuance lay the city or county liable to the owners of the property in damages. Besides this, the ditch is twenty feet deep in places - during the rains often containing fifteen feet of water - makes it exceedingly dangerous.
} 


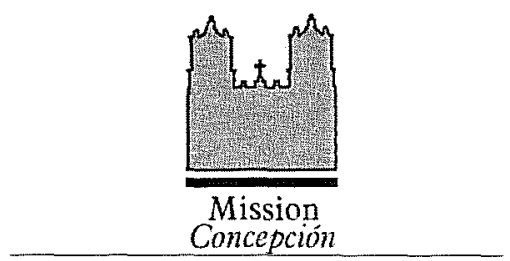

Only a short time since a cart, mule and man were hurled into this trap from the crossing leading from Guenther's mill, the man miraculously escaping death" (San Antonio Express, "Concepción Ditch," February 16, 1869).

The removal of the dam also created another problem for the city, one that had been recognized since the removal had first been proposed, the continued requirement to supply the land owners below the city with their authorized share of water for irrigation. The city engineer met this challenge by diverting the waters of the Alamo acequia, from the point of the aqueduct crossing the now dry ditch, to a new channel on the eastern margin of Garden Street (now South St. Mary's). The new ditch was required because this diversion produced a greatly reduced flow and consequently required a smaller channel.

\section{Previous Investigations}

Six testing and/or excavation projects have previously taken place at Mission Concepción. Figure 3-5 displays the areas examined by these projects. A brief description of each follows.

The walls of Mission Concepción had largely disappeared by the end of the nineteenth century (Corner 1890:16). Although the church had been in use since its rededication in 1861 (Habig 1968a:149), little else of the original Colonial mission was visible above ground. The extent and shape of the original mission compound was not affirmed, though it was known that Mission Road then cut through what had been the middle of the compound.

In the 1930s, as part of a Works Progress Administration (WPA) project, excavations were made around the standing mission walls, and foundations were documented for many buildings that had long-since disappeared (Ivey and Fox 1999:4).
In September and November 1971, and March and April 1972, the Texas State Historical Survey Committee, (now the Texas Historical Commission), sponsored the first archaeological project at the mission. The purpose was to examine the foundations of the Church walls, and determine if the deterioration of the lower walls of the Church was due to foundation problems. The second portion of the project was to relocate the Granary and the west wall of the Colonial period compound (Scurlock and Fox 1977:1). The project determined that the foundation of the Church appeared dry and solid, and located a series of wall remnants. Numerous Colonial, as well as nineteenth and twentieth century middens were documented. The possible remains of acequias were encountered in at least two areas, in Test Pits 14 and 17 (Scurlock and Fox 1977:43), and in Test Pit 50 (Scurlock and Fox 1977:Figure 13). Much of the south and west wall areas were found to be seriously disturbed by bulldozing conducted in the 1950s.

Beginning in December 1980, with a second field phase concluding in June of the following year, CAR continued the search for the original walls of the mission. This report has only recently been published (Ivey and Fox 1999). This excavation confirmed that the southern part of the west wall, and most of the south wall were badly disturbed, while the east and north wall foundation, along with remains of associated rooms, were relatively undisturbed (Ivey and Fox 1999:9, Figure 4). This project also located some of the foundations of the original convento, built before the current building (Ivey and Fox 1999:15). The remains of two sections of acequia were found, one just north of the Church, and the other in the area of the south wall, near the section discovered by Scurlock and Fox (1977). Portions of the east and north walls were also recorded.

In 1986, CAR archaeologists tested an area south of the Church, in order to determine the best route for a drainage pipe needed to end occasional flooding of the convento. Two excavations blocks (one $12 \mathrm{~m}^{2}$ and 

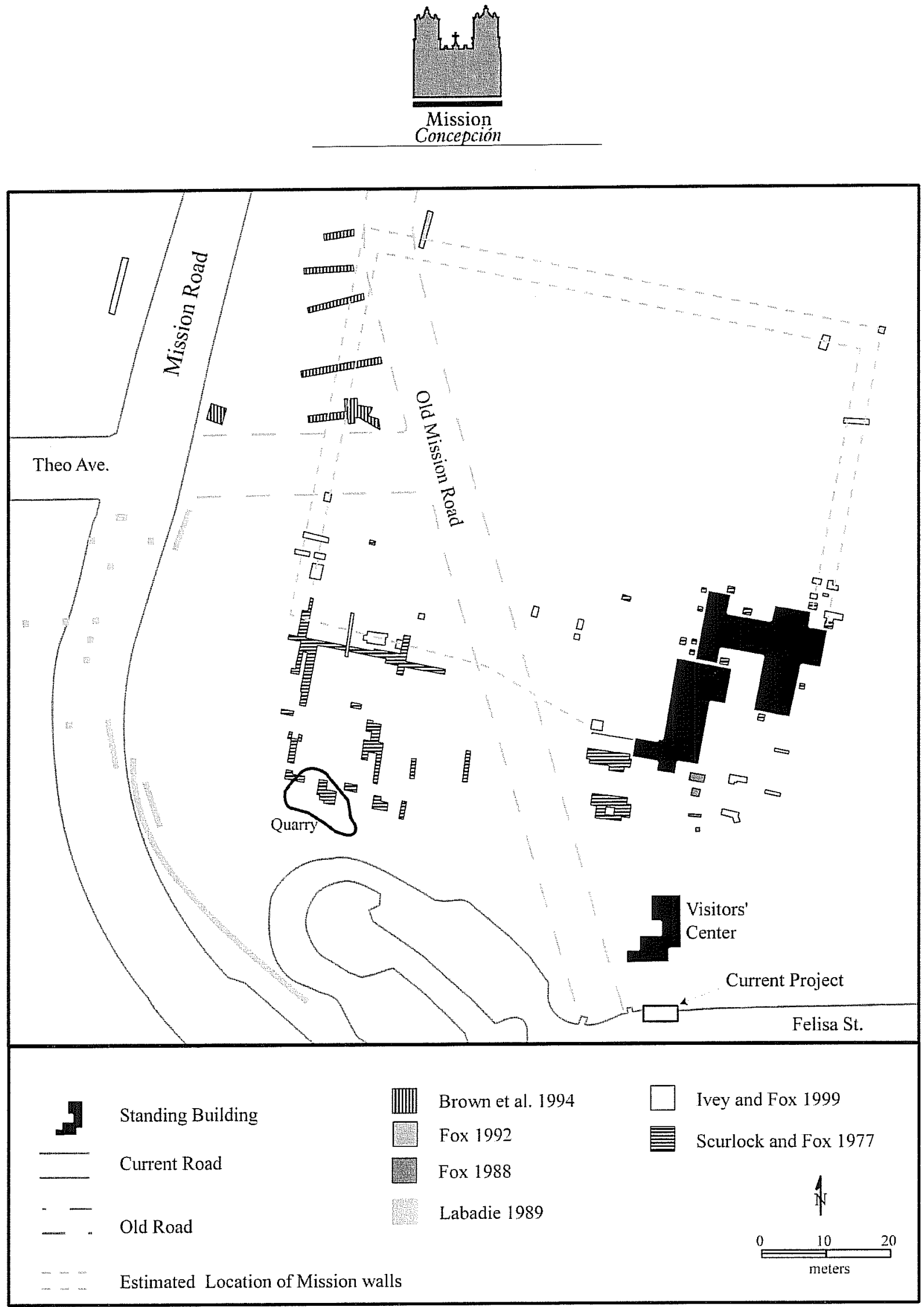

Figure 3-5. Previous excavations at Mission Concepción. 


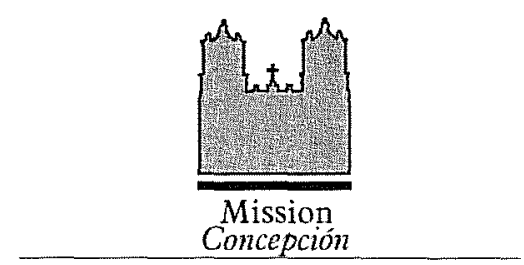

the other $4 \mathrm{~m}^{2}$ were placed south of the convento. These excavations demonstrated:

1) Smith's 1930s WPA maps were based in part on assumptions about the nature of the buried walls, and were not accurate; and

2) Although remains of several walls were present, the artifacts recovered indicated that considerable disturbance had taken place (Fox 1988: 20).

Plans to realign Mission Road outside the compound led to more excavations by CAR in 1987 . This project was intended to locate any important features, especially acequias, that might be impacted when the new Mission road, west of Concepción, was constructed outside the original compound (Labadie 1989). Three backhoe trenches and a series of 11 test trenches located the remains of an acequia, but otherwise showed that the area west of the mission had been seriously disturbed in the past.

CAR personnel also monitored the construction of an electrical conduit trench and a condensation line for an air conditioning system. The electrical conduit trench crossed one wall, presumably part of the foundation of the first convento (Fox 1989).

In 1990, further testing of the area between the old Mission road and the new realignment road located a few remains of the west wall, and otherwise documented extensive disturbance in and around the west wall area. The presumed location of the northwest corner of the mission compound had been disturbed by utility trenches (Brown et al. 1994). An additional test trench was later excavated in an effort to locate the north wall in the area of the northwest corner. Extrapolation from the wall which was located by this trenching activity served to confirm the presumption that the northwest corner of the Church had been destroyed (Fox 1992).

\section{Methodology}

Before the fieldwork began, a brief review of previous literature concerning historic and archaeological work at Mission Concepción was conducted. In particular, previous archaeological reports were examined to determine if there was existing knowledge of an acequia in the project area. While archaeological evidence did not indicate an acequia in the immediate area of the project location, maps from Ivey and Fox (1999:5) showed the estimated location of an acequia described in deed records from the early-nineteenth century (Ivey and Fox 1999: 6-7; Appendix I). Two test trenches had encountered this acequia outside the western wall (as discussed). An extension of the line of this acequia intersected the area of Felisa Street where the feature had been discovered (Figure 3-6). Therefore, it seemed likely that the feature was part of an acequia.

\section{Field Methods}

The purpose of the fieldwork was:

1) To determine the role of the impacted feature;

2) To determine when the feature was filled; and if the feature was filled in the Colonial-period, to mitigate damage to a historic deposit that would occur when the manhole was complete and the trenches for the new electrical conduits dug.

Mark Denton of THC, recommended that the feature be recorded and two test units dug to determine when the feature was filled-in. If there was evidence that the feature was filled during the Colonial-period, four more test units would be dug, as needed, to assess and mitigate damage. 


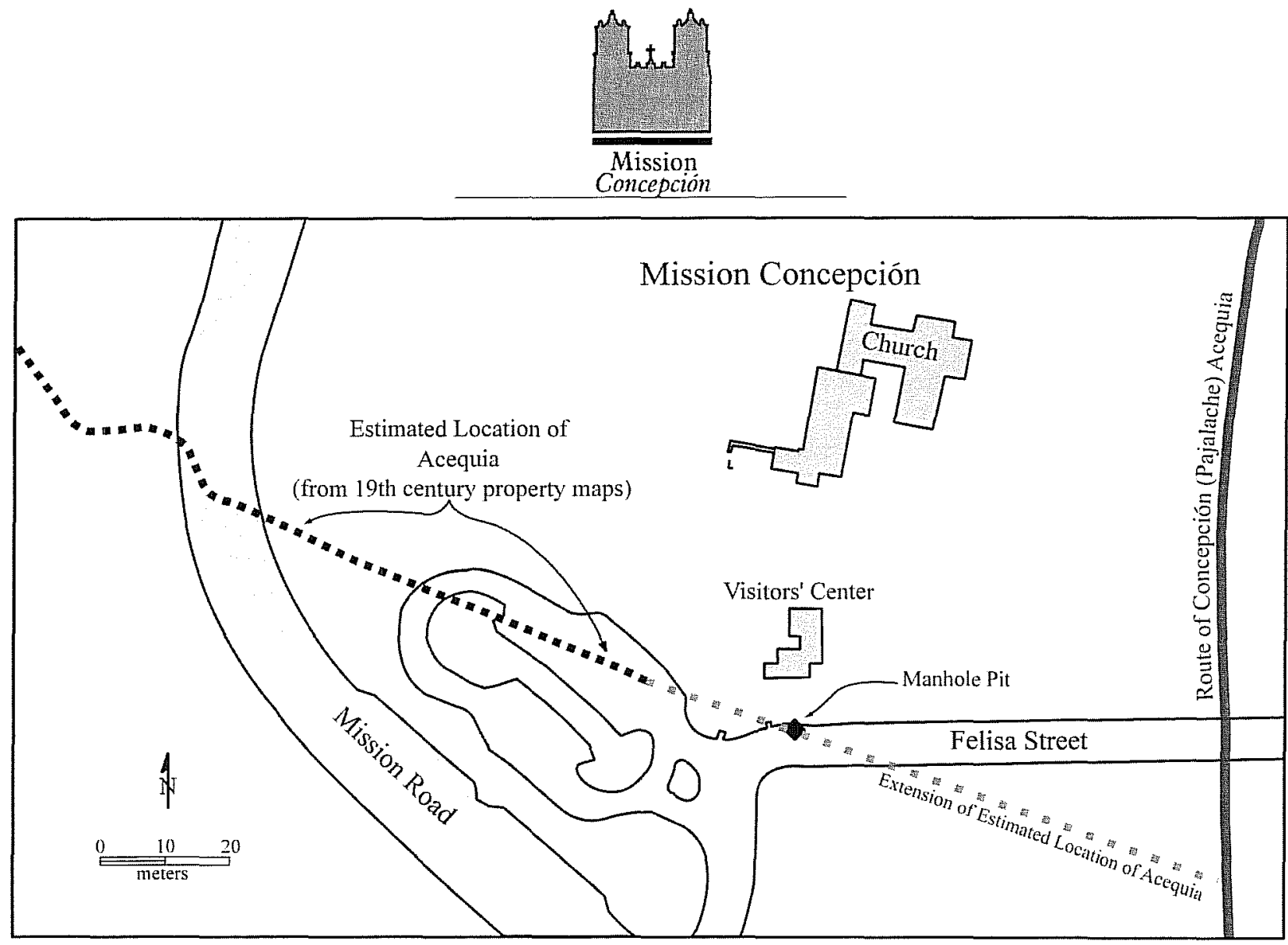

Figure 3-6. Map of area showing line of a possible lateral acequia.

Estimated from early-nineteenth century property survey descriptions, and an extension of this line to Felisa Street (based on Figure 2 in Ivey and Fox 1999:5)

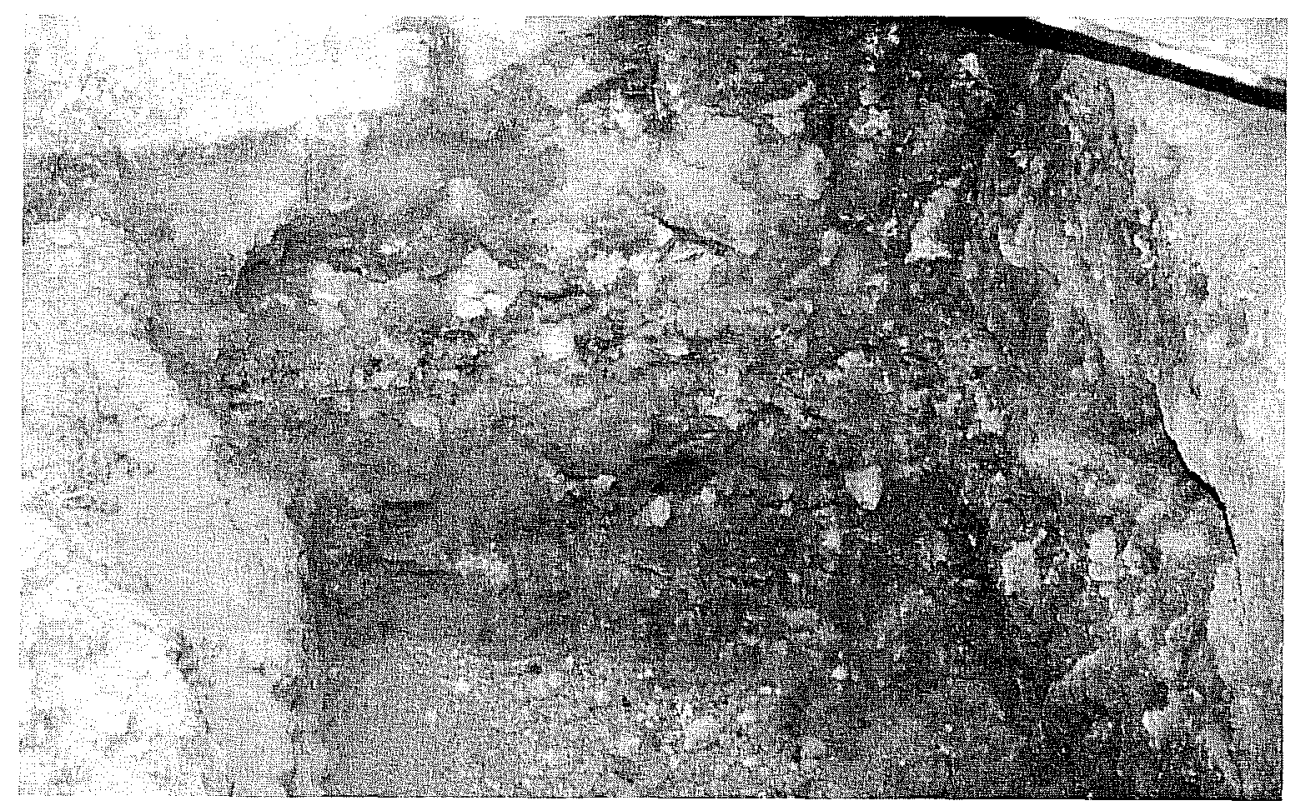

Figure 3-7. The northwest wall of the manhole pit. 


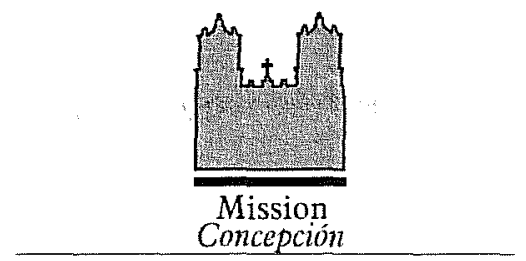

The process of evaluating the nature of the feature was somewhat hampered by the depth of the original manhole pit, which was ca. 7 feet $(2.13 \mathrm{~m})$. Occupational Safety and Health Association (OSHA) regulations would not allow a person to get into the pit unless it was shored, so close observations and measured drawings of the entire profile could not be made. Instead, a series of photographs of the northwest and northeast walls of the pit were taken (Figure 3-7; also Figure 3-3). It was hoped that the lower part of these photographs could be correlated with measured drawings of the upper part of the profiles, allowing an adequate, if less-than-perfect, recording of the portion of the feature impacted by the manhole excavation.

Once these photographs had been taken, the CPS crew backfilled the pit to a depth of ca. 4 feet (ca. $1.25 \mathrm{~m}$ ) below street level. The northwest and northeast walls of the pit were then profiled. Soil samples were taken of each level visible in the profiles. While this was being done, the CPS crew cut the street to the east and west of the manhole pit, and removed the caliche and gravel roadbed with shovels. Test Unit 1 (TU 1) was placed west of the manhole pit, and Test Unit 2 (TU 2) was placed east of the pit (Figure 3-8).
During the fieldwork, four unit datums were established. These were later tied to the project datum, which was established at the southwestern corner of the Visitors' Center, at the level of the top of the concrete slab, immediately below the brick wall (Table $3-1)$. However, in the remainder of this report, the abbreviation "bd" will refer to the appropriate unit datum unless otherwise noted.

All sediments were screened through $1 / 4$-inch $(.64 \mathrm{~cm})$ hardware cloth. Artifacts were bagged by unit and level. Written descriptions of each level were made, and plan maps were drawn when deemed necessary. In order to allow the test pit to be covered with steel plates at the end of the workday, all backdirt was pushed back into the manhole pit daily.

The first $10 \mathrm{~cm}$ of each unit was removed with shovels. Subsequent levels were then dug with trowels, hand-picks, and -in some cases- shovels, in $10 \mathrm{~cm}$ levels unless a major sediment change was noted. An exception was made in Level 2 of TU 2, which was from $10 \mathrm{~cm}$ below datum (bd) to the bottom of the bone bed and ranged from $19 \mathrm{~cm}$ in the southwest corner to $30 \mathrm{~cm}$ in the northeast corner.

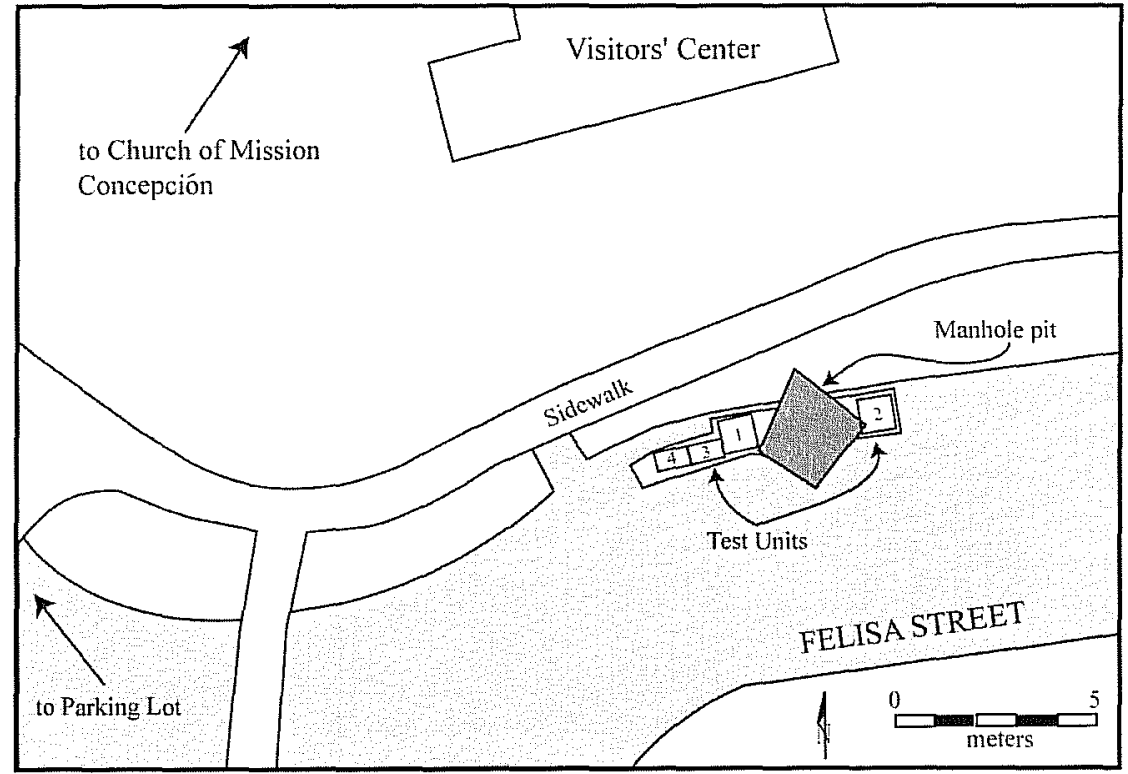

Figure 3-8. Map of manhole pit and test units.
Test units were dug to a depth calculated by examination of the related pit profile to test the entire upper layer that included the large numbers of animal bone (Figure 3$3)$. TU 1 was excavated to a depth of $65 \mathrm{~cm}$ bd. In TU 2 , the layer containing the large number of animal bone terminated at about $30 \mathrm{~cm}$, however, the unit was excavated to a level of $50 \mathrm{~cm}$ bd in order to provide a profile of the feature near its eastern edge.

Initial evaluation of the artifacts recovered in TUs 1 and 2 made it clear that the acequia had been filled during the Colonial period. Only 


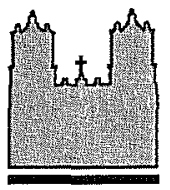

Mission

Concepcion

Table 3-1. Unit datum locations and depths below project datum

\begin{tabular}{|l|l|c|}
\hline \multicolumn{1}{|c|}{ Datum } & \multicolumn{1}{|c|}{ Location } & $\begin{array}{c}\text { Depth below Project } \\
\text { Datum (cm) }\end{array}$ \\
\hline Unit 1 Datum & $\begin{array}{l}\text { Northwest corner of unit, at ground } \\
\text { level (below road bed) }\end{array}$ & 196 \\
\hline Unit 2 Datum & $\begin{array}{l}\text { Southeast corner of unit, at ground level } \\
\text { (below road bed) }\end{array}$ & 185 \\
\hline Units 3 and 4 Datum & $\begin{array}{l}\text { Northwest corner of Unit 3 (northeast } \\
\text { corner of Unit 4), beneath asphalt road }\end{array}$ & 190 \\
\hline Pit Profile Datum & $\begin{array}{l}\text { String line on northwest and northeast } \\
\text { wall profiles }\end{array}$ & 257 \\
\hline
\end{tabular}

two pieces of post-Colonial ceramics, one undecorated creamware and one hand-painted whiteware, were recovered in the two test units, both from Level 1. The remaining 124 ceramics sherds recovered in TUs 1 and 2 were dated to the Colonial period, including unglazed, lead-glazed, and tin-glazed varieties. No artifacts datable to the mid-to-late nineteenth or twentieth century were found below $10 \mathrm{~cm}$ bd in either unit. In addition, at least three articulated lower legs of cattle were excavated in these two units, indicating that the bones had not been seriously disturbed since they were deposited. Therefore, further excavations along the line that the electrical conduit trenches would take to the west of TU 1 were considered necessary. These excavations were needed to find the western edge of the feature and to mitigate damage to the feature prior to the electrical conduit trenches being dug.
The deepest point of this layer was at about $83 \mathrm{~cm}$ bd in the eastern-most portion of TU 3. A pipe trench was discovered in the western-most portion of TU 4 , and a 2-inch iron pipe was uncovered at a depth of 78 $\mathrm{cm}$ bd, running more or less parallel with the western edge of the unit.

The profile of the north wall of TUs 3 and 4 indicated that these units were near the western edge of the feature. The pipe trench which was located in the western portion of TU 4 had probably impacted the feature's western edge. It was not considered necessary to continue excavations for the location of the acequia in this area had been established, and a good sample of artifacts and bone from the upper part of the fill had been taken.

The CPS crew cut the street again, along the line their electrical trench would take. Roadbed was removed by shovel. This cut was made extending west from TU 1 , and was about 2-m long and only as wide as needed for the trench, approximately 65 $70 \mathrm{~cm}$. Two more test units, TU 3 and TU 4 were laid out in the new area (Figure 3-9). These test units were 1-m from west to east, but only $60 \mathrm{~cm}$ from north to south. They were dug to $60 \mathrm{~cm}$ bd. A hard-packed caliche level was reached in the central portion of TU 4 at about $54 \mathrm{~cm}$. The surface of this layer, which dropped down to the east, was followed in the northern half of TU 3 and 4.

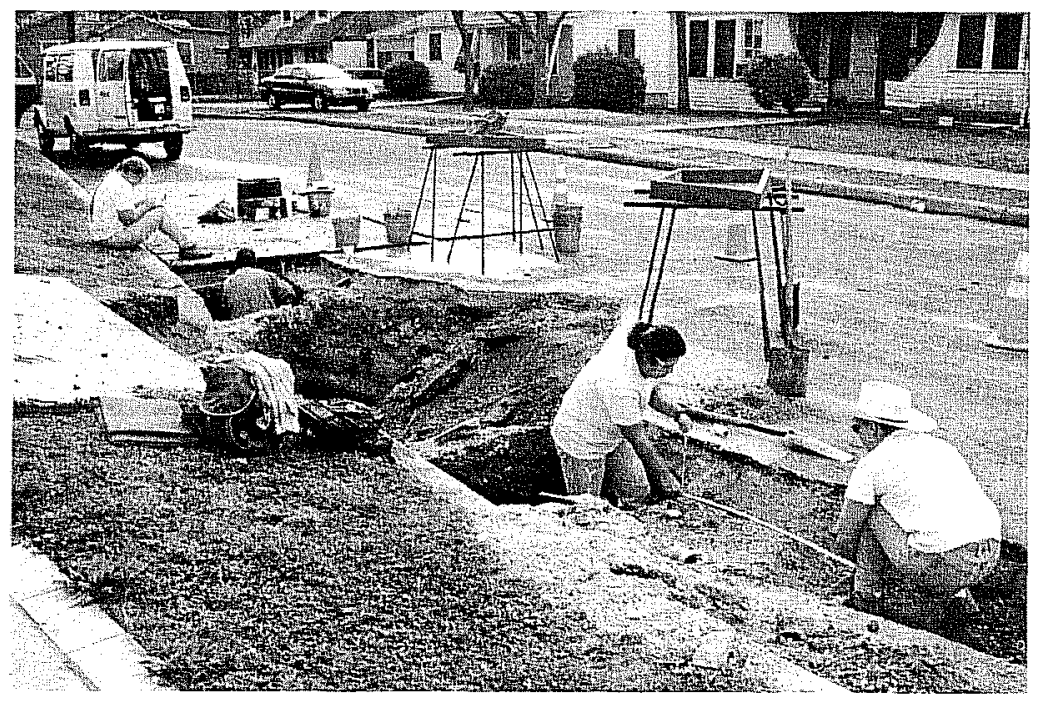

Figure 3-9. Facing southeast - CAR personnel laying out TUs 3 and 4 while others profile east wall of TU 2 . 


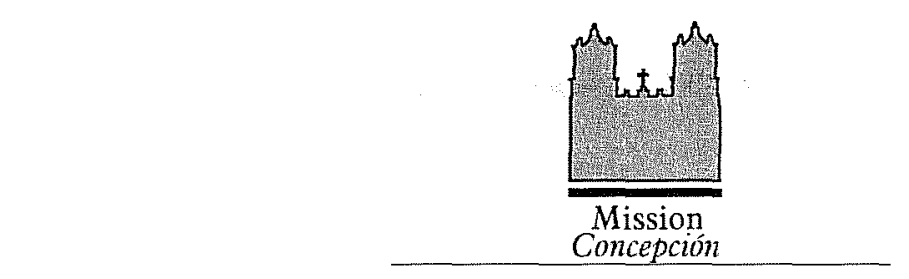

\section{Laboratory Methods}

All artifacts and soil samples were returned to the CAR laboratory daily. All soil samples were air-dried, and Munsell color charts were used to define soil colors.

All artifacts and bones were washed in tap water, brushed with soft brushes when necessary to remove dirt, and air-dried. Care was taken to ensure that the provenience of all artifacts was maintained. Artifacts were labeled when appropriate, cataloged, and then placed in plastic bags with acid-free paper tags identifying items, provenience, and counts. Artifacts were then grouped by type and turned over to analysts. Once this analysis of artifacts was complete, the artifacts and the records pertaining to the Mission Concepción portion of the project were then curated at the laboratory at CAR.

\section{Results}

\section{Pit Wall Profiles}

It was not possible to closely examine the entire profile because the manhole pit was too deep and the walls too unstable to allow personnel to safely enter the pit. Instead, the pit walls were examined, as well as possible from the top of the pit, and then photographed (Figure 3-3 and Figure 3-7). The hole was then partially backfilled and measured profiles of the northeast and northwest profiles were made.

\section{Northeast Pit Wall Profile}

The northeast pit wall clearly showed the slope of an excavated feature, with numerous episodes of fill (Figure 3-10 and Figure 3-3). It is difficult to tell if the bottom of the feature was reached in the original pit excavation, because it could not be examined closely; however, it appears that the feature actually extended somewhat deeper than the excavation. Figure 3-10 shows only the part of the profile above the backfill. The lower part of Figure 3-10 shows layers of sandy silt along the eastern part of the profile, above a layer of hard-packed caliche. No artifacts or bones were seen in these layers which appeared to have been deposited by natural processes. The middle third of the profile consists of layers of limestone rubble, made up of fragments averaging about $7 \mathrm{~cm}$ in their longest dimension. This rubble appears broken, and may have been trimmings from stonework used during construction of the mission. Just above these layers of limestone rubble is a layer of melted adobe with numerous fragments of partially melted adobe bricks. Above this is a loose, very friable layer of sandy clay loam. This layer contains a few pieces of limestone and adobe brick, but no bone or other artifacts appear in the profile. It appears to be the result of natural depositional activities. The next layer above is a sandy clay loam with numerous animal bones, especially at the top and bottom. Past road construction had cut into this deposit, but it is not known how much of it was removed.

The general impression of the profile is that it intersects a deep feature, not quite at a right angle. The feature is deeper to the west, but the profile does not reach the bottom of the feature. The feature is filled with numerous layers representing different depositional episodes, some of which appear to have been deposited naturally while others seem to have been deliberately dumped.

In the Northeast pit wall profile it is only the uppermost layer which appears to contain large numbers of animal bone. 


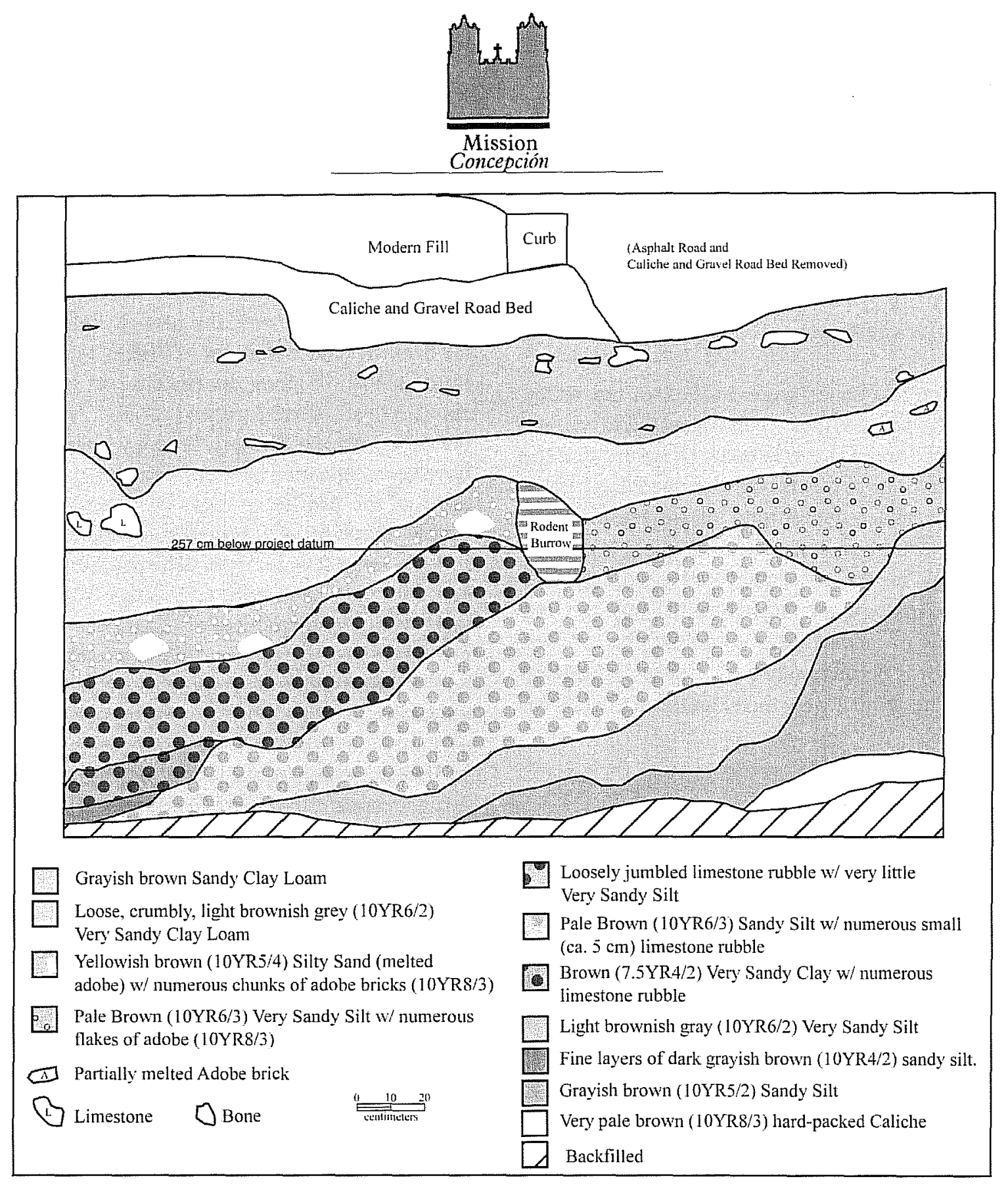

Figure 3-10. Profile of the northeast manhole pit wall.

\section{Northwest Pit Wall Profile}

Clearly, the northwest pit wall profile was a cut near the center of the feature. Unlike the profile of the northeast pit wall, the layers in the northwest pit wall are almost level across the profile (Figure 3-11; Figure 3-7).
The lowest layer visible above the backfill in this profile is of particular interest. It contains numerous micro-layers of sand and very sandy silt. This type of structure is the result of deposition in a stream (or in this case, acequia) channel. On the north side of this profile near the bottom is a small amount of the limestone rubble seen in the northeastern wall. Above this 

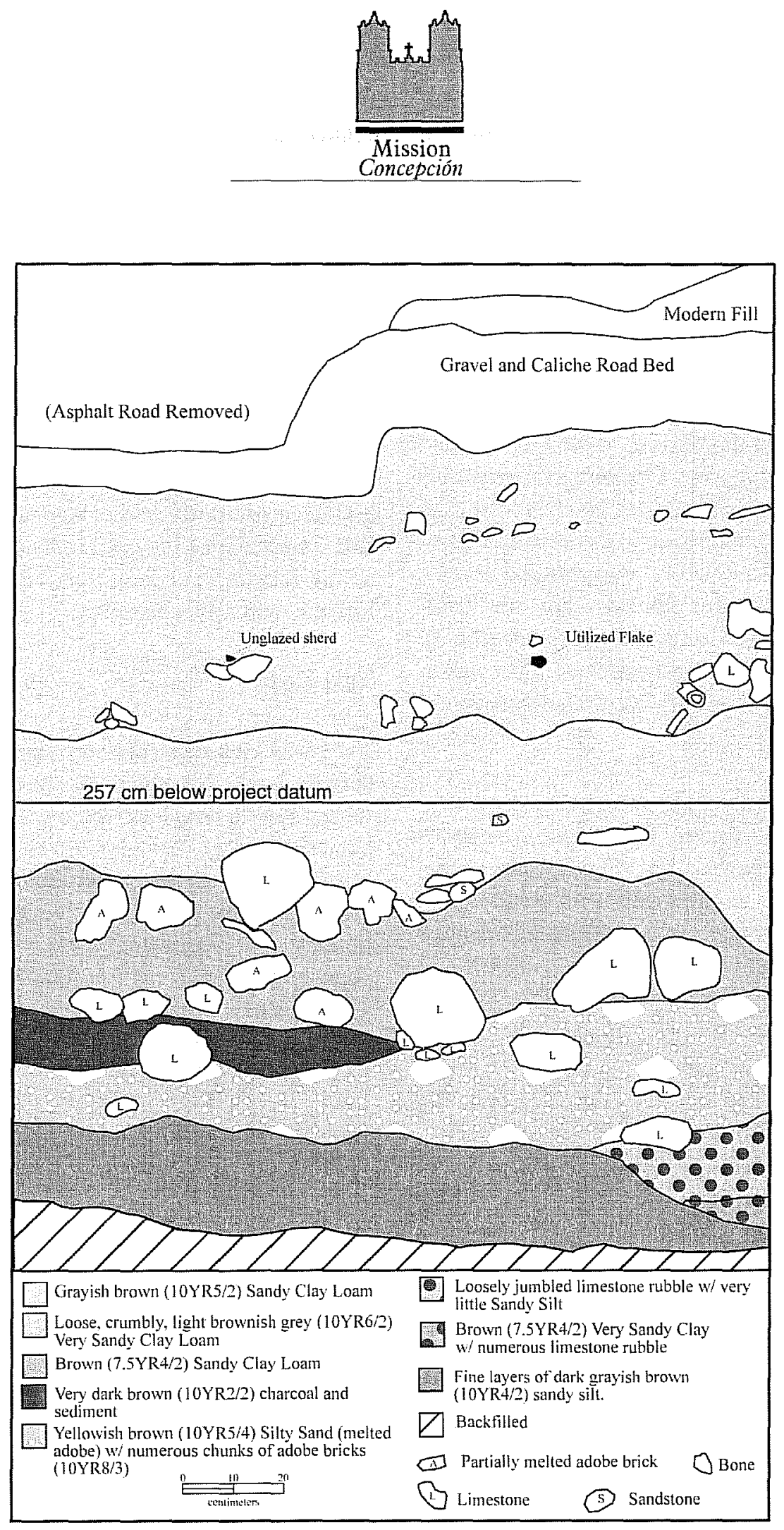

Figure 3-11. Profile of the northwest manhole pit wall. 


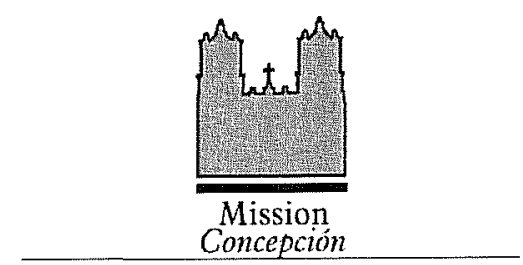

is a thick layer of partially melted adobe bricks that are somewhat glued together by melted adobe. At the western end of this profile is a lens of charcoal and burned limestone that appears to be part of a hearth, although it is possibly a secondary deposit of hearth materials. Above this is a layer of sandy clay loam with numerous limestone fragments, some as large as $20 \mathrm{~cm}$ in their longest dimension, as well as numerous fragments of adobe brick. One large fragment of animal bone was also visible in this layer. Above this is the loose sandy clay loam seen in the northeast profile, believed to be from natural depositional activities. Above is a thick layer of a darker sandy clay loam with numerous animal bones evident in the profile. It is in this layer that a large utilized chert flake and a sherd of unglazed earthenware were also recovered (Figure 3-11).

The northwest pit wall profile seems to represent a diagonal cut near the center of the feature. The presence of sediments deposited by moving water at the bottom of the profile is consistent with an acequia. Most of the fill here appears to be deliberately deposited piles of adobe and limestone rubble, with a thick layer of more general trash deposited on top.

\section{Test Units}

Four test units were excavated during this project. The first two were intended to sample the deposit at the upper level of the feature. Examination of the walls of the manhole pit had made it clear that the largest deposit of animal bone and other trash was in this upper layer. TUs 1 and 2 provided a sample of this trash to allow an assessment of the date at which the acequia had been filled. Once this was accomplished, TUs 3 and 4 were then excavated to locate the western edge of the feature, and to mitigate damage to it and the historic deposits it contains.

\section{Test Unit 1}

TU 1 was located on the west side of the manhole pit (Figure 3-8). The upper $10 \mathrm{~cm}$ of this unit was dug with a shovel, as the sediment was an extremely compacted clay loam (this layer was directly beneath the roadbed of Felisa Street). Animal bone was very common. The bone appeared as large chunks (not the extremely small fragments often seen in Colonial period deposits); however, it was visibly shattered in situ and fell apart when excavated. Many ceramics were present, one -a piece of hand-painted whiteware is postColonial in date (Table 3-2).

Table 3-2. Artifacts recovered from TU 1, by level

\begin{tabular}{|c|c|c|c|c|c|c|c|c|c|}
\hline Level (depth bd) & 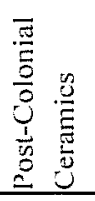 & $\begin{array}{l}\frac{n}{0} \\
\frac{\tilde{g}}{0} \\
\end{array}$ & 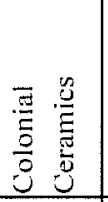 & 苞 & 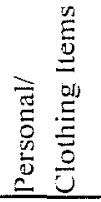 & 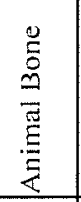 & Other & Total & Notes \\
\hline $1(0-10 \mathrm{~cm})$ & 1 & 10 & 29 & 7 & & 521 & 6 & 574 & Very compacted; animal bone shattered \\
\hline $2(10-20 \mathrm{~cm})$ & & & 19 & 2 & & 427 & 5 & 453 & \\
\hline $3(20-30 \mathrm{~cm})$ & & 2 & 25 & 5 & 1 & 3780 & 17 & 3830 & glass bead \\
\hline $4(30-35 \mathrm{~cm})$ & & 1 & 8 & 5 & & 926 & 3 & 943 & \\
\hline $5(35-45 \mathrm{~cm})$ & & & 18 & 7 & 1 & 1189 & 8 & 1223 & glass bead \\
\hline $6(45-55 \mathrm{~cm})$ & & & 8 & 2 & & 449 & 5 & 464 & \\
\hline $7(55-65 \mathrm{~cm})$ & & & 1 & 2 & & 72 & & 75 & \\
\hline Total & 1 & 13 & 108 & 30 & 2 & 7364 & 44 & 7562 & \\
\hline
\end{tabular}




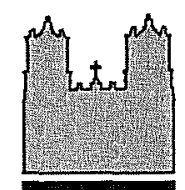

Mission

Concepción

In this unit, from $10 \mathrm{~cm}$ to $55 \mathrm{~cm}$ bd, there were numerous limestone chunks, with occasional smaller pieces of sandstone, and also ceramics, lithics, plus a large number of animal bones (Figure 3-12).

In two cases, one occurring at $29 \mathrm{~cm}$ bd and the other at $40 \mathrm{~cm}$ bd, the lower legs of cattle were found articulated (Figure 3-13).

At about $35 \mathrm{~cm}$ bd, there was a sediment change to a darker, looser, sandy clay loam with numerous chunks of charcoal. Animal bone was in larger pieces and in better condition below $35 \mathrm{~cm}$ bd. At ca. $55 \mathrm{~cm}$ bd, another sediment change occurred -this layer was a dark sandy clay wherein the artifact and bone content dropped off sharply. Below about $58 \mathrm{~cm}$ bd no bone or other artifacts were recovered. The unit was terminated at $65 \mathrm{~cm}$ bd (Figure 3-14).

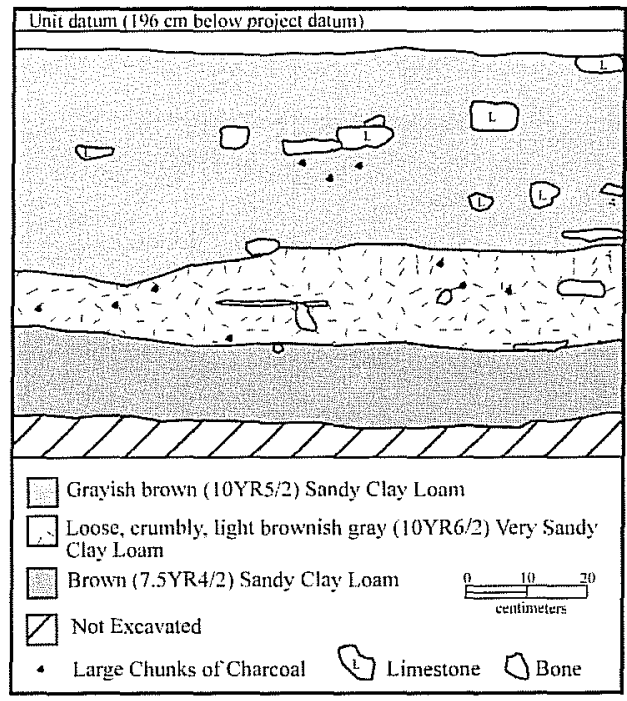

Figure 3-12. Profile of the north wall of $T U 1$.

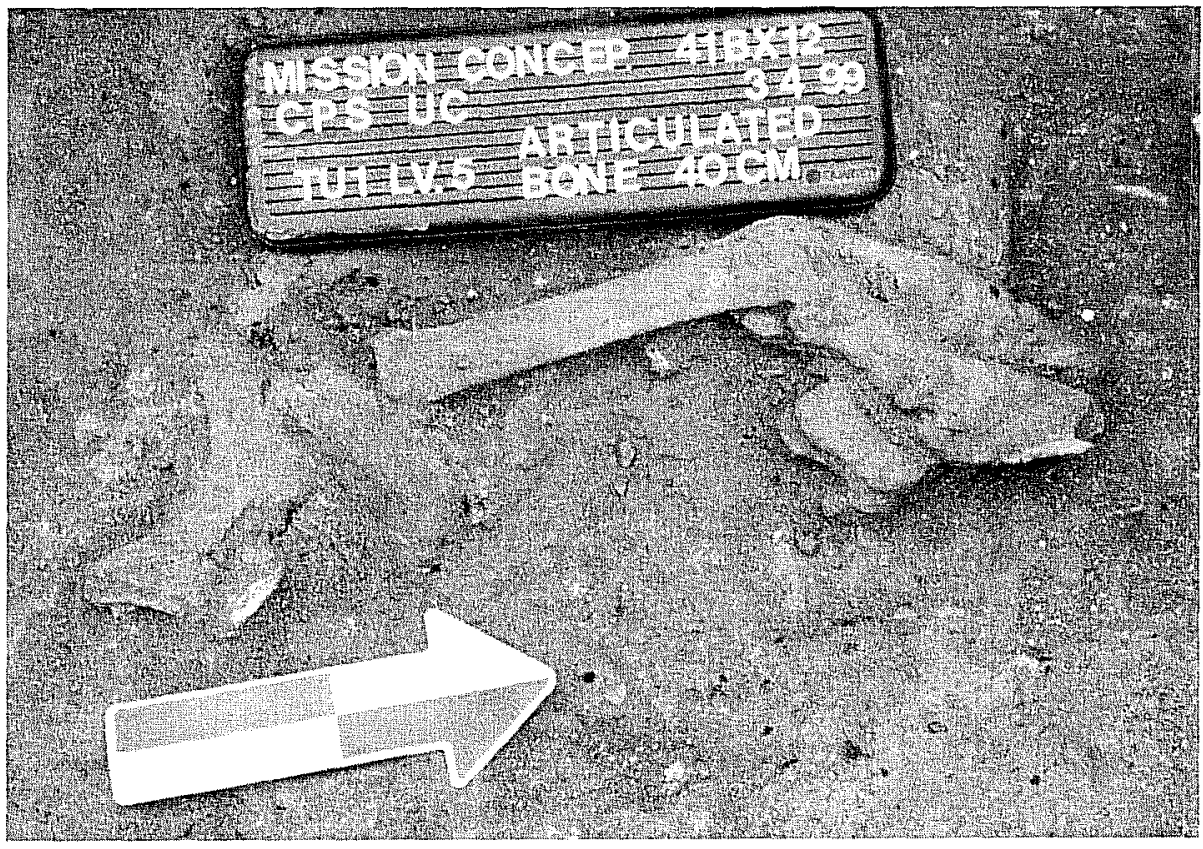

Figure 3-13. Articulated lower leg of cow at $40 \mathrm{~cm} \mathrm{bd}$. 


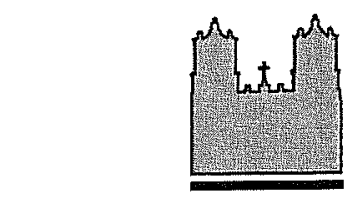

Mission

Concepción

Artifacts recovered from this unit included glazed and unglazed Colonial ceramics, 2 glass beads, and 4 lithic tool fragments, as well as 26 pieces of chert debitage.

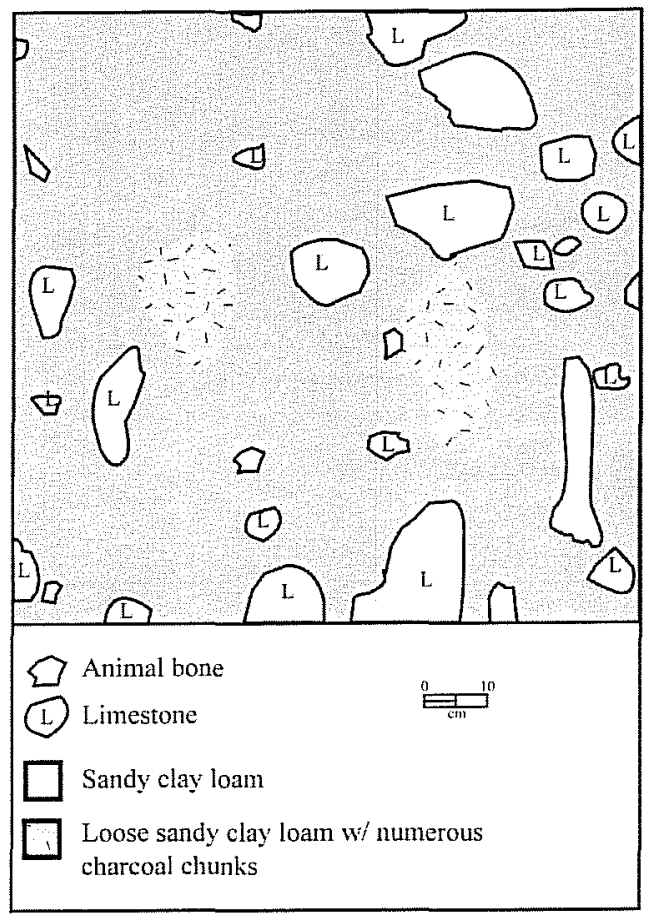

Figure 3-14. Plan map of TU 1 at $30 \mathrm{~cm} \mathrm{bd}$.

\section{Test Unit 2}

TU 2 was located to the east of the manhole pit (Figure 3-8). The clay loam of the first $10 \mathrm{~cm}$ of this unit was even more compacted than in TU 1. Numerous large limestone rocks were present, especially in the northern part of the unit (Figure 3-15). A glass bead was recovered from near the bottom of Level 1; however, only 4 ceramics were recovered, one of which was a sherd of creamware. Animal bone counts in TU 2, Level 1 were higher than counts recorded from TU 1 (Table 3-3).

The next level was excavated to the bottom of the bone deposit, which corresponded with a sediment change to a clay loam mottled with caliche. This sediment change was evident at about $19 \mathrm{~cm}$ bd in the southeastern corner of the unit and sloped downward towards the northwest, to a depth of $30 \mathrm{~cm}$ bd, at which point the sediment was pure caliche (Figure 3-16). A glass bead was found in Level 3 in the mottled clay and caliche layer above the caliche (Table 3-3). This layer of caliche was very soft, but was sterile. Below it was a layer of sandy clay loam with numerous caliche nodules. Several pieces of majolica were found in this layer, but very little animal bone was present. Beneath this was another layer of caliche, which was very hard-packed, almost the texture of soft limestone. In the northwestern corner of the unit there was a lens of dark sandy clay with numerous gravels in it, which may have been an animal burrow. This unit was terminated at $70 \mathrm{~cm}$ bd, however, no artifacts or bone was recovered below $50 \mathrm{~cm}$ bd.

There was a notable difference between TU 2 and TU 1 . The former had only a few $(n=11)$ ceramic sherds and only 9 lithics, of which 2 were tool fragments and the rest debitage. Examination of the profile of the north wall made it clear that this unit was very near the eastern edge of the feature. 

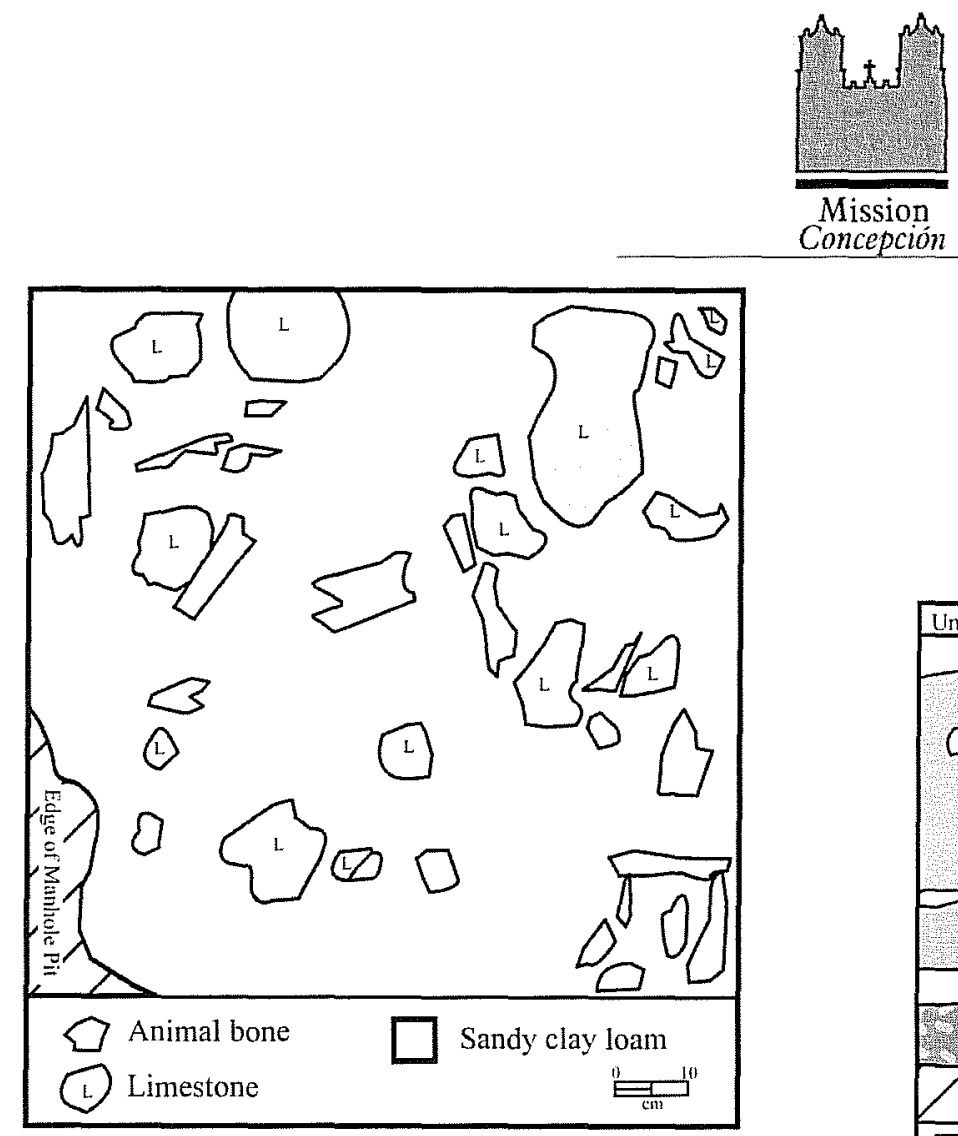

Mission

Concepción

Figure 3-15. Plan map of TU 2 at $10 \mathrm{~cm} \mathrm{bd}$.

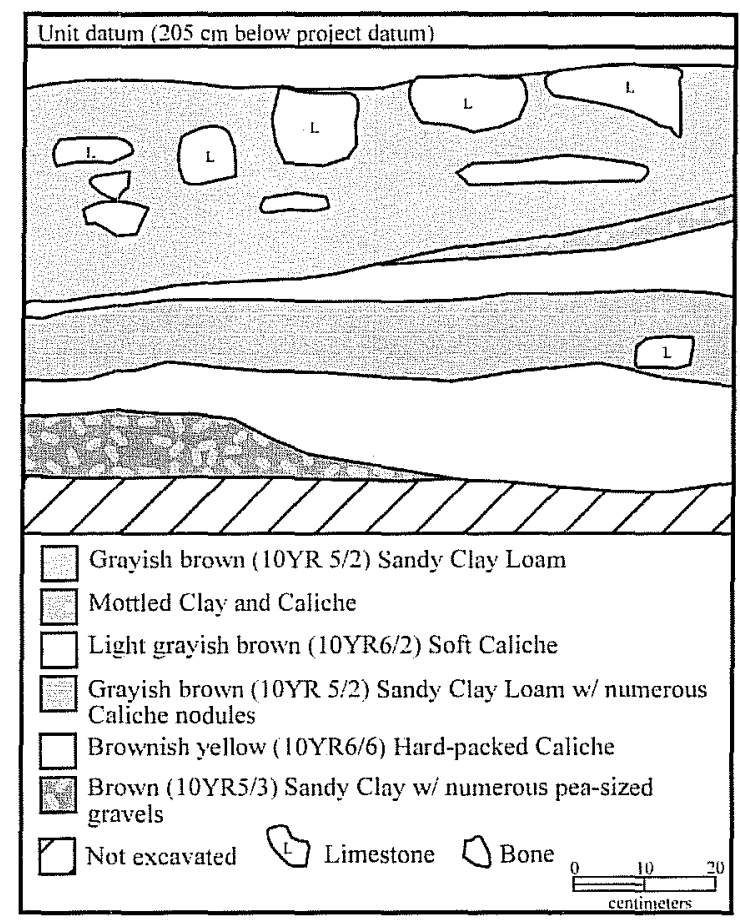

Figure 3-16. Profile of north wall of TU 2.

Table 3-3. Artifacts recovered from TU 2, by level

\begin{tabular}{|c|c|c|c|c|c|c|c|c|c|}
\hline Level (depth bd) & 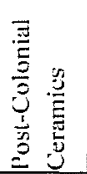 & 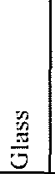 & $\begin{array}{l}\bar{\Xi} \\
\frac{3}{5} \\
\frac{3}{3} \\
3\end{array}$ & 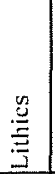 & 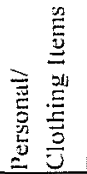 & 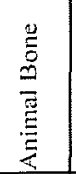 & Other & Total & Notes \\
\hline $1(0-10 \mathrm{~cm})$ & 1 & & 3 & & 1 & 902 & 12 & 919 & Glass bead \\
\hline $2(10-30 \mathrm{~cm})^{*}$ & & & 2 & 2 & & 5374 & & 5378 & \\
\hline $3(20-30 \mathrm{~cm})^{* *}$ & & & 3 & 1 & 1 & 831 & 3. & 839 & Glass bead \\
\hline $4(30-40 \mathrm{~cm})$ & & & 1 & 3 & & 180 & & 184 & \\
\hline $5(40-50 \mathrm{~cm})$ & & & 7 & 3 & & 11 & & 21 & \\
\hline Total & 1 & 0 & 16 & 9 & 2 & 7298 & 15 & 7341 & \\
\hline
\end{tabular}

* Bone bed

** Below the bone bed, above $30 \mathrm{~cm}$ bd 


\section{Test Unit 3}

TU 3 was located adjacent to TU 1 , in the road-cut made for the planned electrical conduit trench (Figure 3-8). This roadcut was deliberately limited to the width of the trench, so TU 3 was only $60 \mathrm{~cm}$ from north to south by $1 \mathrm{~m}$ from east to west.

Similar to the first two units, the upper $7-10 \mathrm{~cm}$ was very hardpacked clay loam. The density of animal bone in this level was somewhat less than in either of the previous units; however, a large number of Colonial-period ceramics were present (Table 3-4). A large glass bead and a copper alloy button were also recovered. Between $35-40 \mathrm{~cm}$ bd, a lens of charcoal mixed with sandy clay, burned pea-sized gravels, and larger (ca. 5 $\mathrm{cm}$ ) burned limestone chunks was encountered in the northern $2 / 3$ of the unit. This lens seemed to terminate to the east at a large limestone rock (Figure 3-17) and did not continue into TU 1. Large chunks of animal bone were deposited on top of this lens. Below this lens the artifact count dropped.
In TU 3, only 3 ceramics and 2 lithics were recovered between 40 and $80 \mathrm{~cm}$ bd (Table 3-4). Excavations in the northern $30 \mathrm{~cm}$ of this test unit continued below $70 \mathrm{~cm}$ to expose the north wall profile down to a layer of hard white caliche. The caliche surface sloped downwards from west to east, to a depth of $83 \mathrm{~cm}$ at the northeastern corner of the unit (Figure 3-18). The unit was terminated at this point.

Table 3-4. Artifacts recovered from TU 3, by level

\begin{tabular}{|c|c|c|c|c|c|c|c|c|c|}
\hline Level (depth bd) & 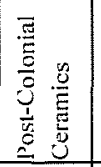 & 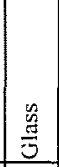 & 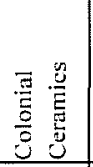 & 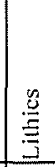 & 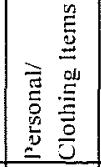 & 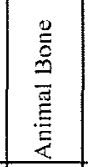 & Other & Total & Notes \\
\hline $1(0-20 \mathrm{~cm})$ & & 1 & 31 & 2 & 2 & 421 & 11 & 468 & Glass bead, copper alloy button \\
\hline $2(20-30 \mathrm{~cm})$ & & & 4 & & & 785 & 10 & 799 & \\
\hline $3(30-40 \mathrm{~cm})$ & & & 10 & & & 1333 & & 1352 & \\
\hline $4(40-50 \mathrm{~cm})$ & & 1 & 2 & 1 & & 439 & 5 & 448 & \\
\hline $5(50-60 \mathrm{~cm})$ & & & & & & 47 & & 47 & \\
\hline $6(60-70 \mathrm{~cm})$ & & & 1 & & & 168 & & 169 & \\
\hline $7(70-83 \mathrm{~cm})^{*}$ & & & & 1 & & 17 & & 18 & \\
\hline Total & & 2 & 48 & 7 & & 3210 & 32 & 3301 & \\
\hline
\end{tabular}

* North $1 / 2$ only 


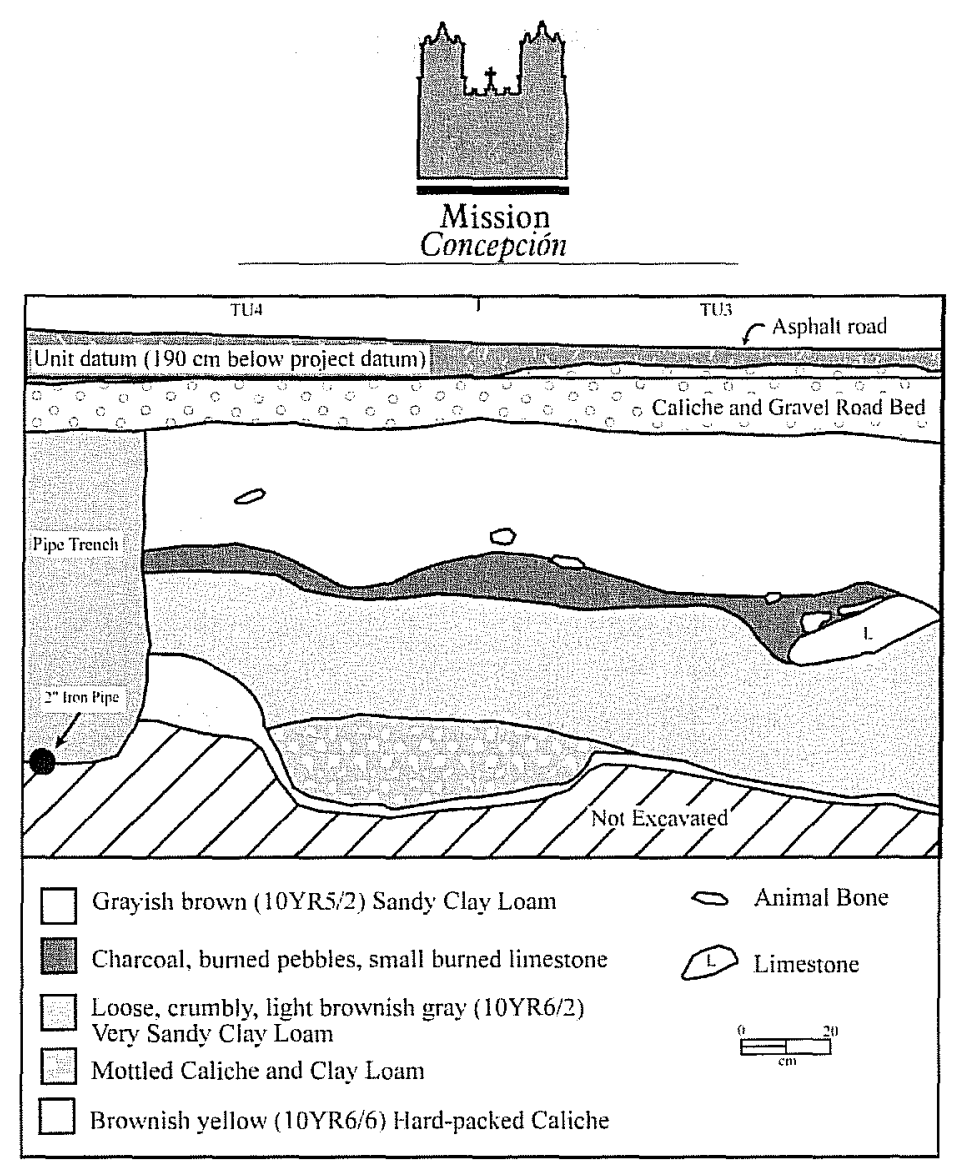

Figure 3-18. Profile of north wall of TU 3 (right) and TU 4 (left).

\section{Test Unit 4}

TU 4 was adjacent the west side of TU 3 (Figure 3-8). The upper surface of the unit was hard-packed clay loam; however, there were notably fewer animal bones in this unit. There was also more modern-looking glass and other post-Colonial artifacts, including a large metal " $D$ " ring. All of the post-Colonial artifacts were found in the western third of the unit. By the bottom of Level 2 (at $30 \mathrm{~cm} \mathrm{bd}$ ) had been reached a distinct sediment difference was noted in this western portion of the unit (Figure 3-19). This area was later shown to be a pipe trench.
At about 35 to $40 \mathrm{~cm}$ bd the dark lens of charcoal and burned pebbles noted in TU 3 was encountered east of the pipe trench and continued across the northern part of the unit. At $54 \mathrm{~cm}$ bd a hard-packed caliche layer was encountered in the center of TU 4 . As excavation continued, this layer was shown to slope steeply into a shallow pit filled with mottled caliche and sandy clay loam. This pit extended to the eastern edge of the unit (Figure 3-18). The unit was terminated at the bottom of the pit, when the hard caliche layer was reached. The western section of the unit was excavated to the bottom of the pipe trench. A 2-inch cast iron pipe was encountered at $78 \mathrm{~cm}$ bd. 


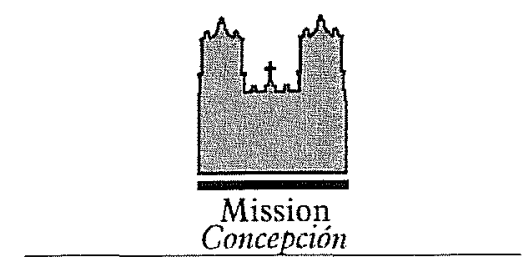

Thirty-six Colonial-period ceramics and fifteen lithics, including 3 tool fragments were recovered in this unit (Table 3-5).
By combining the profiles of the north walls of these units with the northeast and northwest walls of the manhole pit, a composite profile of the acequia can be drawn (Figure 3-20).

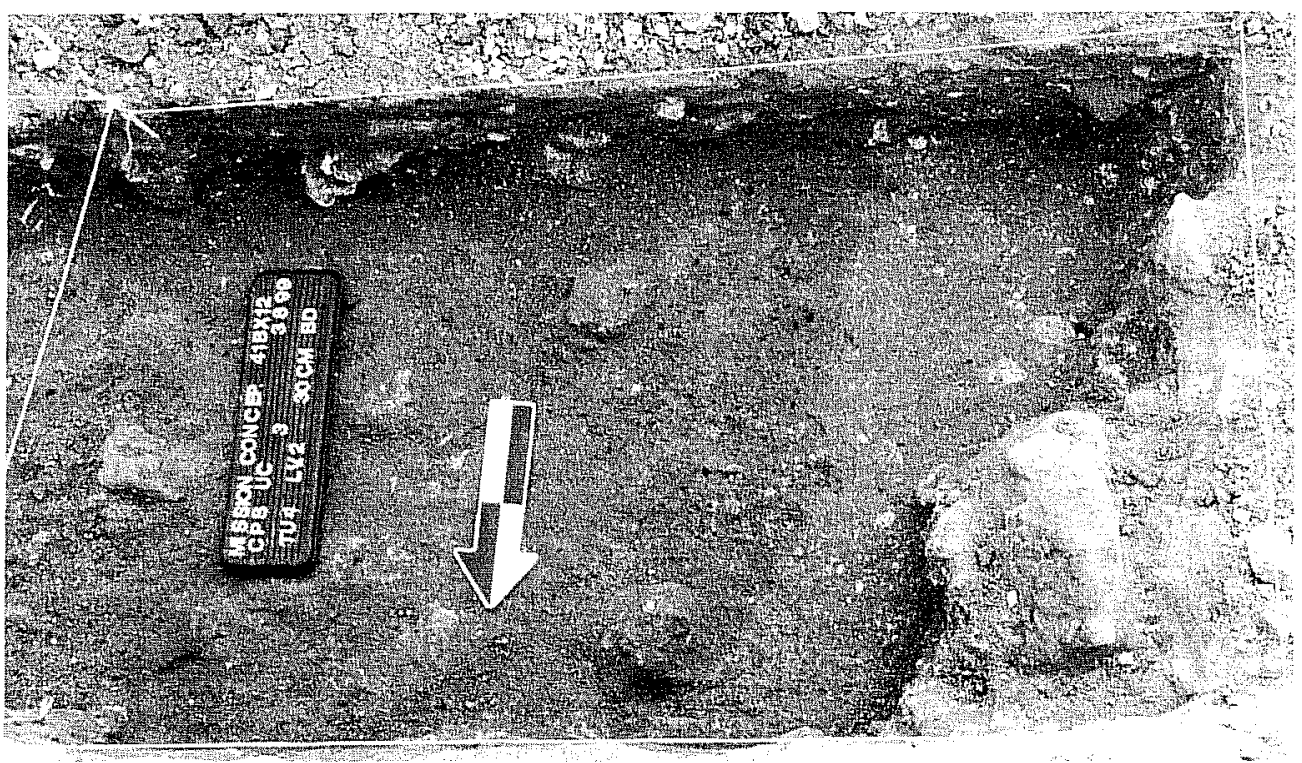

Figure 3-19. TU 4, indicating evidence of pipe trench in western $1 / 3$ of Test Unit 4 (right side). Looking south.

Table 3-5. Artifacts recovered from TU 4, by level

\begin{tabular}{|c|c|c|c|c|c|c|c|c|c|}
\hline Level (depth bd) & 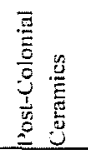 & $\frac{\frac{\mathscr{U}}{E}}{\tilde{v}}$ & 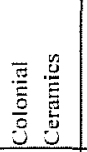 & 苞 & 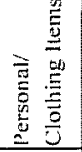 & $\frac{\mathscr{O}}{E}$ & Other & Total & Notes \\
\hline $1(0-20 \mathrm{~cm})$ & & 2 & 8 & 3 & & 274 & 2 & 289 & \\
\hline $2(20-30 \mathrm{~cm})$ & & 4 & 6 & 4 & & 1011 & 7 & 1032 & \\
\hline $3(30-40 \mathrm{~cm})$ & & & 15 & 3 & & 549 & 10 & 577 & \\
\hline $4(40-50 \mathrm{~cm})$ & & 1 & 6 & 2 & & 23 & & 32 & \\
\hline $5(50-60 \mathrm{~cm})$ & & & 1 & 1 & & 4 & & 6 & \\
\hline $6(60-70 \mathrm{~cm})$ & & & & 2 & & 17 & & 19 & \\
\hline $7(70-83 \mathrm{~cm})^{*}$ & & & & & & 4 & & 4 & \\
\hline Total & & 7 & 36 & 15 & & 1882 & 19 & 1959 & \\
\hline
\end{tabular}

* North $1 / 2$ only 


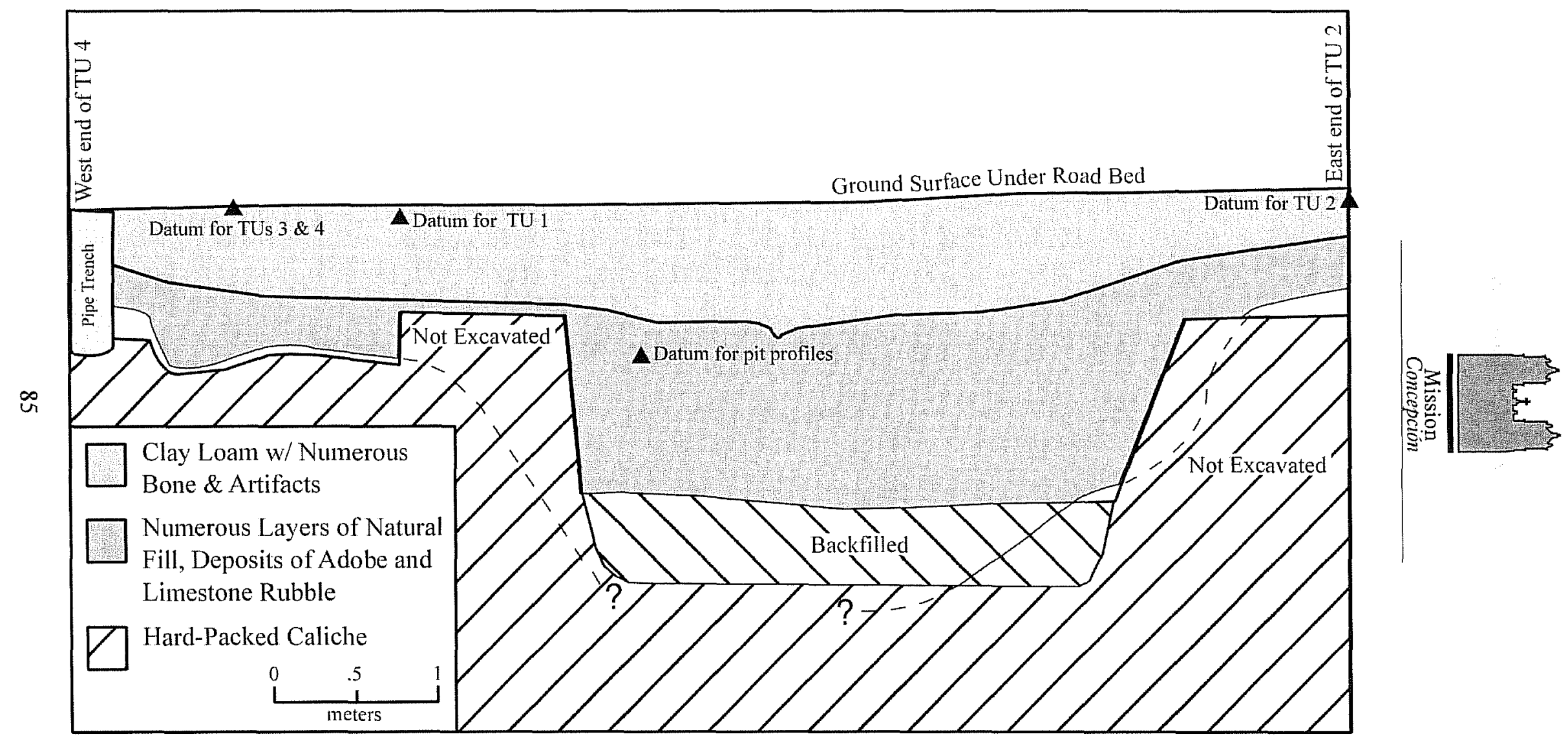

Figure 3-20. Composite profile of the north wall of the acequia. 


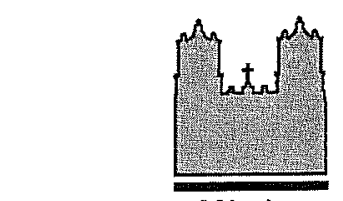

Mission

Concepcion

\section{Artifact Analysis}

\section{Donna D. Edmondson}

The artifact assemblage recovered during excavations at Mission Concepción contains objects that are commonly found on many of the San Antonio mission sites. Dates for the assemblage range from the Spanish Colonial period to the early-nineteenth century. The categories include ceramics, glass, metal and miscellaneous items. The eighteenth century artifacts are directly related to the occupation of the mission site. The late-nineteenth century artifacts are probably deposits of the vecinos or citizens who made up the community of the Mission Concepción site after secularization (Tomka and Fox 1998:17). A provenienced list of all artifacts recovered during the Mission Concepción portion of the project is curated at the laboratory at CAR.

\section{Ceramics}

The items which are found to be most useful for dating deposits at Spanish Colonial sites are ceramics. Throughout the eighteenth and nineteenth centuries ceramic styles changed regularly, as did manufacturing techniques. The ceramics in this analysis are separated into three common groups:

\section{Unglazed wares; \\ Glazed wares; and Whitewares.}

A provenienced list of ceramics is curated at the laboratory at CAR.

\section{Unglazed Wares}

Several types of unglazed ceramics recovered from excavations conducted during the course of this project are wares usually found on Spanish Colonial sites in San Antonio. Goliad ware predominates, while the next most common type is a wheel-turned utility ware, made in Mexico, known as Valero. Only two examples of burnished-ware, possibly made in Mexico, or elsewhere in Texas, were recovered.

Goliad ware (Figure 3-21a) is a hand-built pottery, made locally by mission inhabitants. Goliad ware has a reddish-brown to dark brown coarse-grained paste tempered with bone. The exterior is unevenly constructed and the interior is black in color, due to the low firing

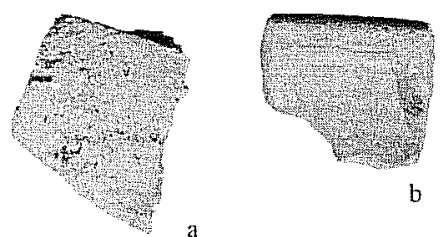

a

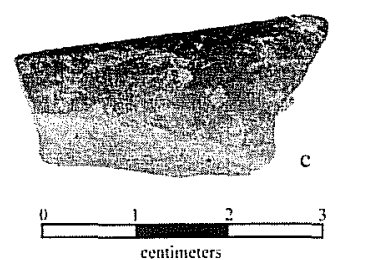

Figure 3-21. Unglazed wares: a) Goliad sherd; b) Valero ware sherd; c) Red Burnished sherd. temperature. Ivey and Fox (1999:36) have suggested that this type of ceramic is a direct continuation of the Late Prehistoric tradition of Central and South Texas known as Leon Plain. Artifact inventories of the Spanish Colonial period in San Antonio and the Guadalupe River Valley are dominated by this ceramic type, which also suggests that it was locally made (Fox et al. 1976:67). This type was the most common Colonial ceramic collected during this project.

Valero ware (Figure 3-21b) is a wheel-made pottery with smooth paste that ranges from pink to tan in color. Fine sand and occasionally crushed bone is used for tempering (Hard et al. 1995:42). This pottery was evenly fired at a higher temperature than Goliad ware. Vessels were mainly large water jars. Three sherds were found during the excavation of this project, two rim sherds and one body sherd. This type of pottery was popular at area missions ca. 1730 to 1760 (Hard et al. 1995:42). 


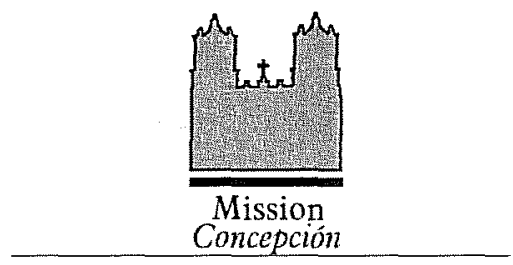

Excavations on this project recovered only two small sherds of Red Burnished ware (Figure 3-21c). Redburnished is a fine-tempered, red paste ware that has a well-polished red slip exterior. Dates for use of this type are ca. 1750 to 1830 (Hard et al. 1995:42).

\section{Glazed Wares: Lead- and Tin-glazed Wares}

Lead-glazed wares were most probably imported from the interior of Mexico to frontier missions (Hard et al. 1995:42). This collection contains 18 lead-glazed earthenware sherds with the paste ranging in color from sandy orange to dark brown (Figure 3-22). The glazes vary in thickness and color, ranging from light green, to dark green, to a reddish brown. Lead-glazed earthenware were generally utility items such as bowls and olive jars which date to the eighteenth century.

Another type of earthenware recovered at Mission Concepción were tin-glazed wares, or majolicas. Majolicas are lead-glazed wares that have tin added to the glaze to create an opaque background for colored enamel decoration (Tomka and Fox 1998:22). The paste ranges in color from cream to pink with a cream to white opaque glaze. The decoration ranges

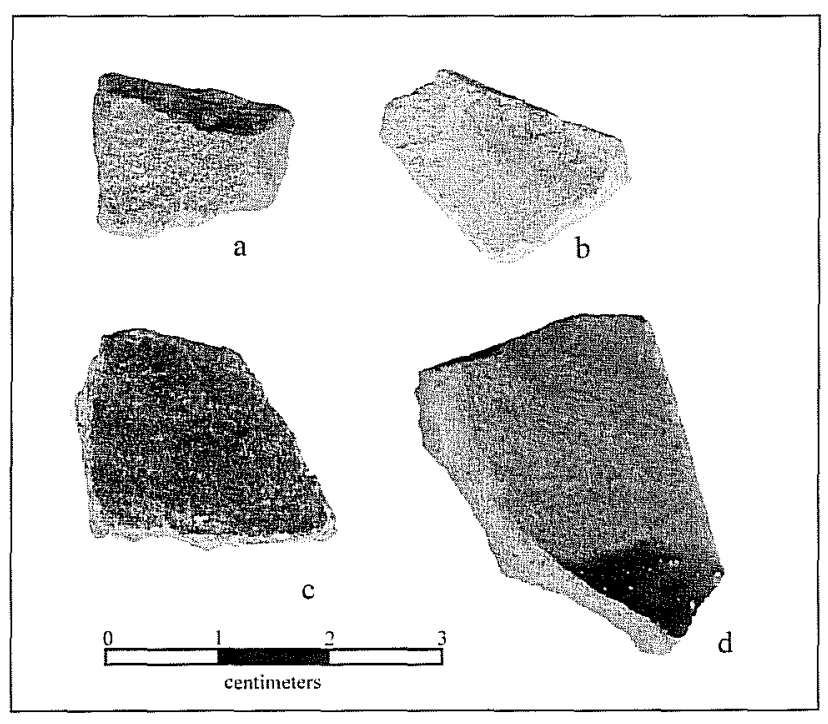

Figure 3-22. Examples of lead-glazed wares. in color from two shades of blue to orange, green, brown and black. The style of decoration or pattern also varies from geometric lines to delicate flowers and swirls. Patterns changed over time, making majolicas useful for dating purposes. Eighty-three tinglazed sherds were identified.

Twenty-two undecorated majolica sherds were collected at this site. They could represent undecorated vessels, which were made during the eighteenth century or the sherds could be undecorated sections of vessels with designs (Tomka and Fox 1998:23).

San Agustín Blue on White is a pattern with a distinct usage of color. Two shades of blue are used in a floral design with a white background. Plates of this type have large, light blue bands on the underside of the $\mathrm{rim}$. The accepted date for this design is 1700 to 1730 , although some later sites have also contained samples of this type of vessel sherd (Goggin 1968:189). One large sherd of this variety was recovered during this project (Figure 3-23a).

Eight sherds are classified as a variant of Puebla Blue on White II (Figure 3-23b-d). The design consists of pale blue bands and dark blue dots or petals, with a few black accent marks (Goggin 1968:191; Siefert 1977:186). Goggin (1968:191) notes that this is a late variety of Puebla Blue on White, seen after 1750.

San Elizario (Figure 3-23e-f) is another sub-type of Puebla Blue on White and is dated from 1750 to 1800 (Gerald 1968:45). The design pattern consists of blue on white rim bands and alternating petals and flowers, like Puebla Blue on White, but these have dark brown to black accents and lines outlining the design (Tomka and Fox 1998:23).

Five sherds represent another, as yet unnamed, type of Blue on White with black accents in the collection (Figure 3-23g). The design is much like Puebla Blue on White II. The dates for this type of majolica are from the middle to late-eighteenth century (A. Fox, personal communication, 1999). 


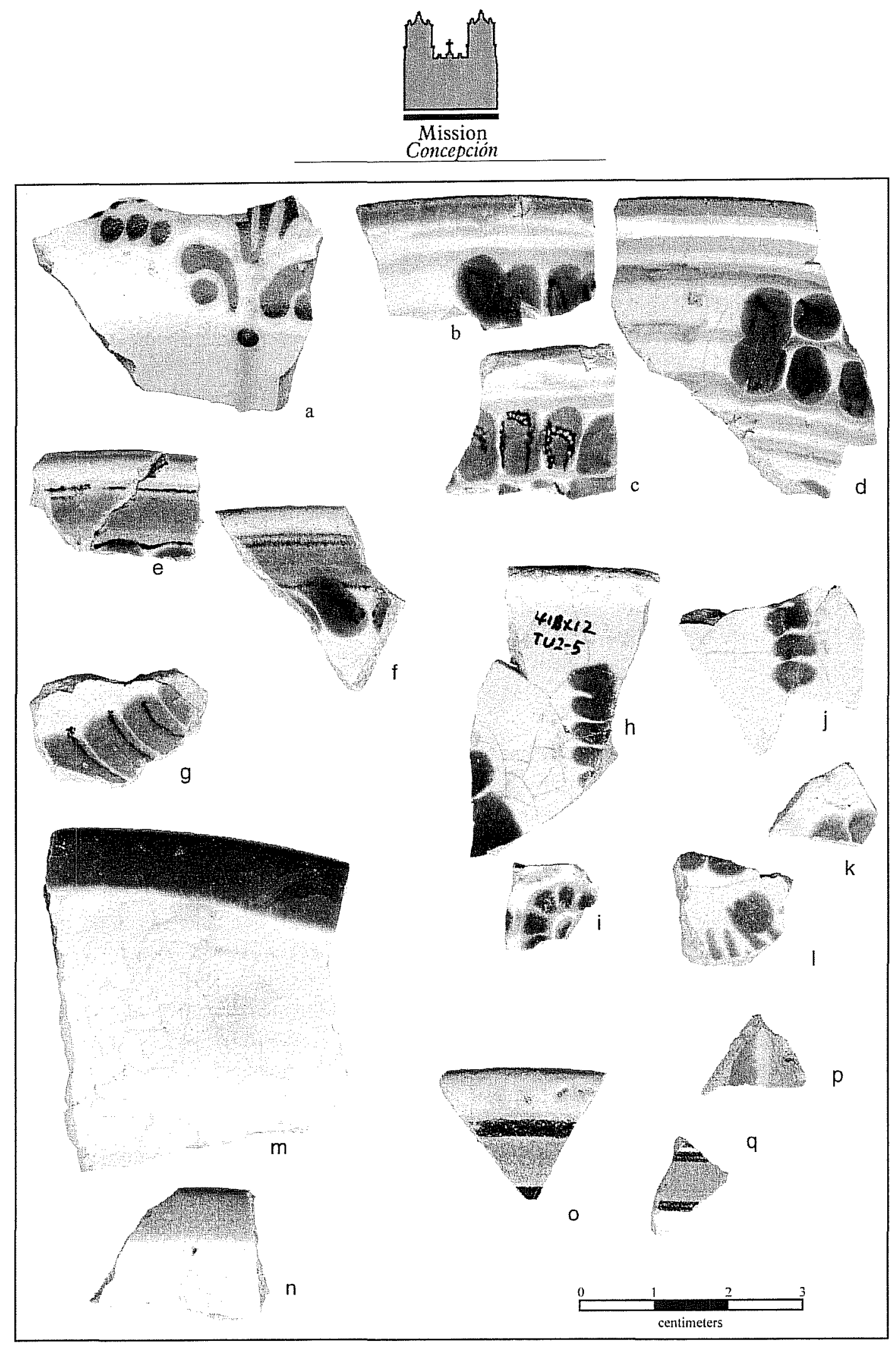

Figure 3-23. Examples of tin-glazed wares: a) San Agustin; b-d) Puebla Blue on White II variant; e-f) San Elizario Blue on White; g) unnamed Blue on White with black accents; h-l) unidentified Blue on White; $\mathrm{m}-\mathrm{n}$ ) Huejotzingo Blue on White; o-q) unidentified polychromes. 


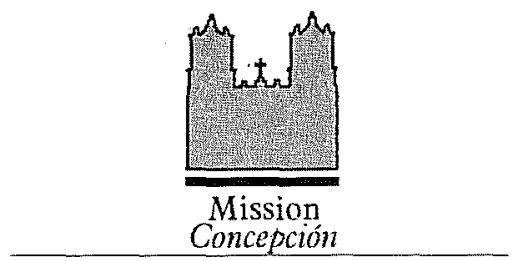

Blue on White is a general category for unidentified patterns similar to Puebla Blue on White ceramics (Tomka and Fox 1998:23). Twenty-six sherds were recovered and a few have a discernible floral pattern, but the majority of the sherds are too small to permit differentiating of patterns (Figure 3-23h-l). Accepted dates for this style are 1730-1800 (A. Fox, personal communication, 1999).

Huejotzingo Blue on White is a simple style that has been dated from 1700 to the nineteenth century, which makes it of little use for dating (Figure 3-23m-n). The pattern is a single blue band that covers the lip and adjacent inside and/or outside of the rim (Goggin 1968:195). Occasionally, vessel sherds have been recovered in South Texas with the single wavy or scalloped band of green or yellow (A. Fox, personal communication, 1999). Nine sherds have been identified in this collection.

The final type of tin-glazed ceramics recovered at Mission Concepción is polychrome. In the collection are five sherds with varying patterns. Two rim sherds have an orange band with brown accent lines bordering on either side (Figure 3-23o, q). One body sherd has three lines painted on it. One line is green, the middle line is white and the other outside line is orange. The last two body sherds are orange to yellow and brown in color, yet the pieces are very small (Figure 3-23p), making identification of specific types impossible. In comparison with larger sherds in another collection, the design is probably floral. The polychrome dates to post-1750 (C. Tennis, personal communication, 1999).

\section{Whitewares and Creamwares}

Whitewares and creamwares are associated with postSpanish Colonial occupation of sites in San Antonio. Whitewares are named for the white paste and clear glaze, which evolved through various stages in England (Hard et al. 1995:45). Cream-colored wares also evolved in England and are named for their cream-colored paste and clear glaze. In the collection there is one whiteware sherd which is the bottom of a saucer or cup. The inside of the piece has hand-painted green leaves (Figure 3-24). There are four molded creamware sherds that are too small to differentiate. In San Antonio both wares were in use during the earlynineteenth century.

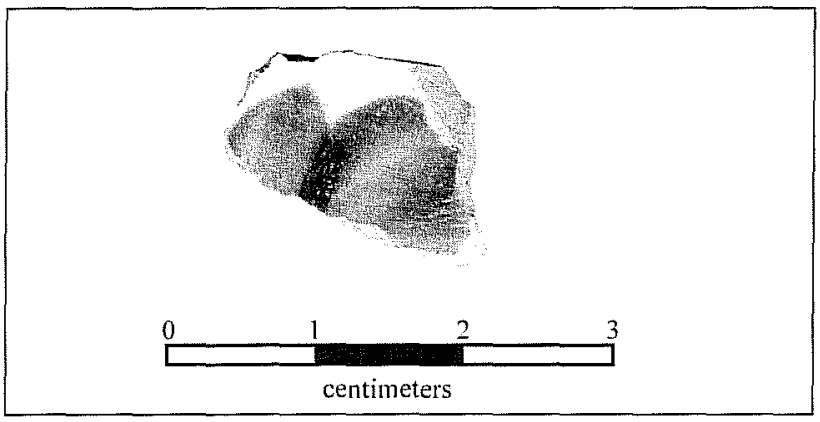

Figure 3-24. Handpainted whiteware sherd.

\section{Glass, Metal and Miscellaneous Artifacts}

\section{Glass Containers}

Twenty-four fragments of glass containers were recovered during this project, in various colors - green, brown and clear. Of the 24 fragments, 7 fragments were green glass probably from Colonial period wine bottles (Tomka and Fox 1998:24). Below Level 1, only fragments of green and clear glass consistent with the Colonial period were recovered (Hard et al 1995:48), except for the western end of TU 4 , where a pipe trench had disturbed older deposits.

\section{Metal Objects}

Five metal objects were identified during this project. During excavation of Unit 1, in Levels 4 and 6, two square nails were recovered. Due to the large amount of rust buildup, it could not be determined if they were 


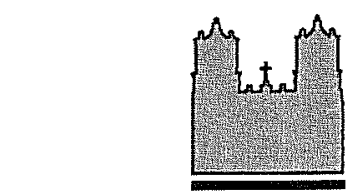

Mission

Concepción

handwrought (forged) or cut nails. Handwrought nails date to before the end of the eighteenth century. Cut nails were in use from the late-eighteenth century to the nineteenth century (Santucci 1981:4-6).

A large metal saddle ring (D-shaped) was recovered in the pipe trench at the west end of Unit 4. A metal ring and a large metal nut were also recovered.

Thirty unidentifiable fragments of metal were recovered on this project. Of these, 11 were iron scrape and 19 were copper scrape. Both types of fragments were found throughout the various levels. The iron fragments are a variety of shapes and sizes, of which two are possible strap pieces or handles. The copper fragments are possibly from copper sheeting, which may date to the Colonial period.

\section{Clothing}

In the collection of historic artifacts recovered at Mission Concepción, a single copper alloy button was identified (Figure 3-25). The button is a one-piece, castback type, with a drilled eye, and dates to the eighteenth century (A. Fox, personal communication, 1999).

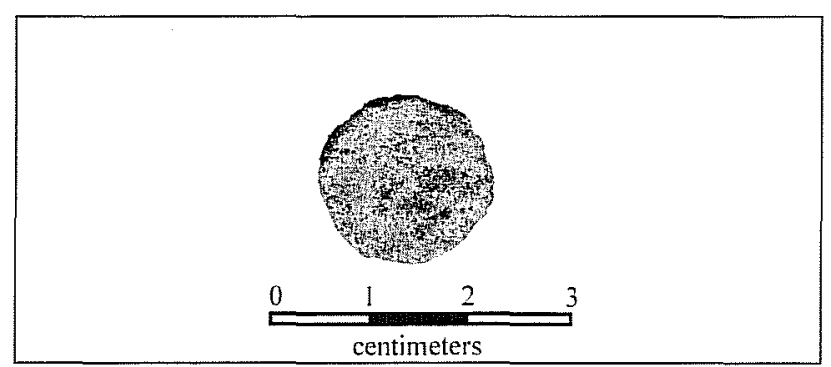

Figure 3-25. Copper-alloy button.

\section{Jewelry}

Five glass trade beads were recovered during excavations. One bead is referred to as a necklace bead, due to its large size. The other four beads are small to medium in size and are referred to as garter beads, used in decorating skins, garters, and items of a similar nature. They are classified below according to the identification and description chart of R. K. Harris (1967:139-147).

\section{Type 15}

Medium, Gobelin Blue, opaque, barrel-shaped garter bead of simple construction (Figure 3-26a-c). The glass is porcelain-like in texture. Of Type 15, 3 beads were collected at this site and in further research this type of bead has been found at two other sites: the Womack site (Harris et al. 1965:310) and the Gilbert site (Jelks 1967:100). This bead type dates from ca. 1719 to 1767 .

\section{Type 86}

Large brick red, opaque, donut-shaped garter bead of compound construction (Figure 3-26d). The outer layer of glass is brick red, and the inner layer is translucent light green. This bead is generally referred to as "Cornaline d'Aleppo." One bead of this type was recovered during excavations. This type has also been found at the Gilbert site (Jelks 1967:104) and at San José (Hard et al. 1995:58). The bead dates from ca. 1740 to 1767 .

\section{Type 87}

A small brick red, opaque, donut-shaped necklace bead of compound construction (Figure 3-26e). Only one bead of Type 87 was found during excavation. Two other sites have documented beads of this type: Mission San Juan Capistrano (Schuetz 1969:59), and the Gilbert site (Jelks 1967:104). This bead dates from ca. 1740 to 1767 . 


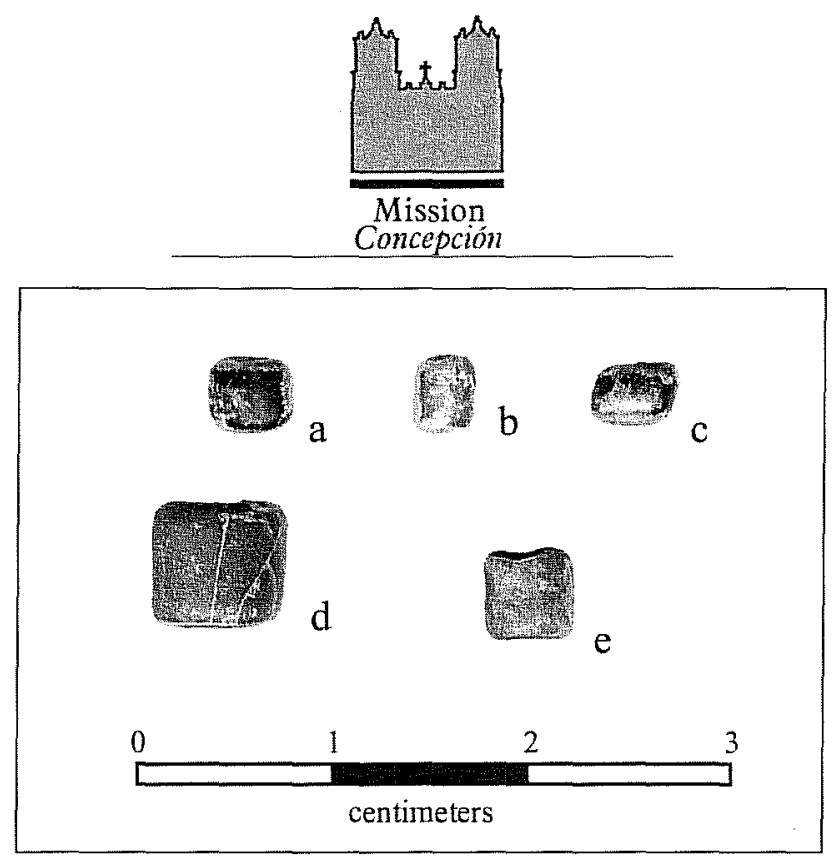

Figure 3-26. Glass beads: a-c) Type 15; d) Type 86; e) Type 87.

\section{Arms}

A single percussion cap was found in cleaning up the northeast wall of the excavation area. Percussion arms were introduced into the United States in 1817 by Jacob Shaw and were in general use by the 1830 s. During the period of 1823 to 1846 percussion arms would have been privately owned (Tordoff 1979:43). 


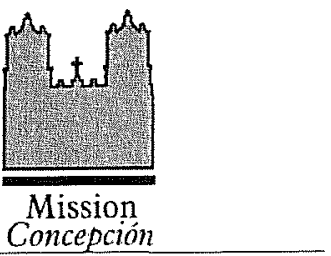

\section{Lithic Artifact Analysis}

\author{
Steve A. Tomka
}

Sixty-seven chipped lithic artifacts were recovered. Eleven of these are finished or manufacture-broken tools and cores (Table 3-6). The tools are categorized into two functional groups: scrapers and knives. The use of the artifacts was determined by low-powered (80x) micro-wear analysis. Six additional flaked artifacts could not be grouped into functional categories. They consist of three unifacially flaked artifacts and three manufacture broken bifaces. They are classified as indeterminate unifaces and bifaces, respectively. A single core also was recovered, in addition to 56 pieces of unmodified lithic debitage. All artifacts are of finegrained chert.

\section{Scrapers}

Three artifacts were identified as scrapers based on the use wear and tool morphology (Table 3-6). From the location of the working edge, all three are classified as side scrapers. Based on the degree of retouch on their working edges, one of the scrapers has a minimally retouched working edge (Figure 3-27a). The remaining specimens are expedient tools not having been retouched either before or after use (Figure 3-27b-c). All three are made on tertiary flakes.

\section{Knife}

A single, longitudinally split, secondary flake has been identified as a knife (Figure 3-27d). The irregular

Table 3-6. Chipped Lithic Tools Recovered

\begin{tabular}{|c|c|c|c|c|c|c|}
\hline \multirow{3}{*}{ UNIT } & \multirow[b]{2}{*}{ LEVEL } & \multirow[b]{2}{*}{ TOOL TYPE } & \multicolumn{3}{|c|}{ Maximum Dimensions (mm) } & \multirow[b]{2}{*}{ Blank/Comments } \\
\hline & & & Length & Width & Thickness & \\
\hline & & & $(\mathrm{mm})$ & $(\mathrm{mm})$ & $(\mathrm{mm})$ & \\
\hline & & Scrapers & & & & \\
\hline 1 & 4 & Minimally Retouched Side Scraper & 44 & 53 & 13 & Tert., flake \\
\hline 2 & $\underline{2}$ & Expedient Side Scraper & 42 & 16 & 5 & Tert., flk., edge \\
\hline \multirow[t]{2}{*}{3} & $7($ N. 1/2) & Expedient Side Scraper Frag. & & 31 & 4 & Tert., flk., frag. \\
\hline & & Sin & & & & \\
\hline & 3 & $\frac{\text { Knives }}{\text { Expedient Knife }}$ & 64 & 30 & 9 & Longitudinally split secondary flake \\
\hline \multirow{2}{*}{1} & & & & & & Longltudinally split secondary flake \\
\hline & & Miscellaneous Biface & & & & \\
\hline 1 & 3 & Early Reduction Stage Biface & & 53 & 18 & Made on secondary flake \\
\hline 2 & 5 & Early Reduction Stage Biface & & 38 & 11 & Made on tertiary flake \\
\hline \multirow[t]{2}{*}{3} & 4 & Early Reduction Stage Biface & & 42 & 16 & Indet, core type \\
\hline & & Indetromingth Unitange & & & & \\
\hline 1 & 3 & $\begin{array}{l}\text { Indeterminate Unifaces } \\
\text { Indeterminate Uniface Edge }\end{array}$ & & & 13 & Secondary flake retouched on side \\
\hline 4 & 2 & Indeterminate Uniface Edge & & 28 & 16 & Secondary blade retouched on side \\
\hline \multirow[t]{3}{*}{4} & 5 & Indeterminate Uniface & & 27 & 13 & Heavily reworked uniface \\
\hline & & & & & & \\
\hline & & Cores & & & & \\
\hline 4 & 6 & Split Pebble Core & 72 & 69 & 26 & Chert pebble, two attempts \\
\hline
\end{tabular}




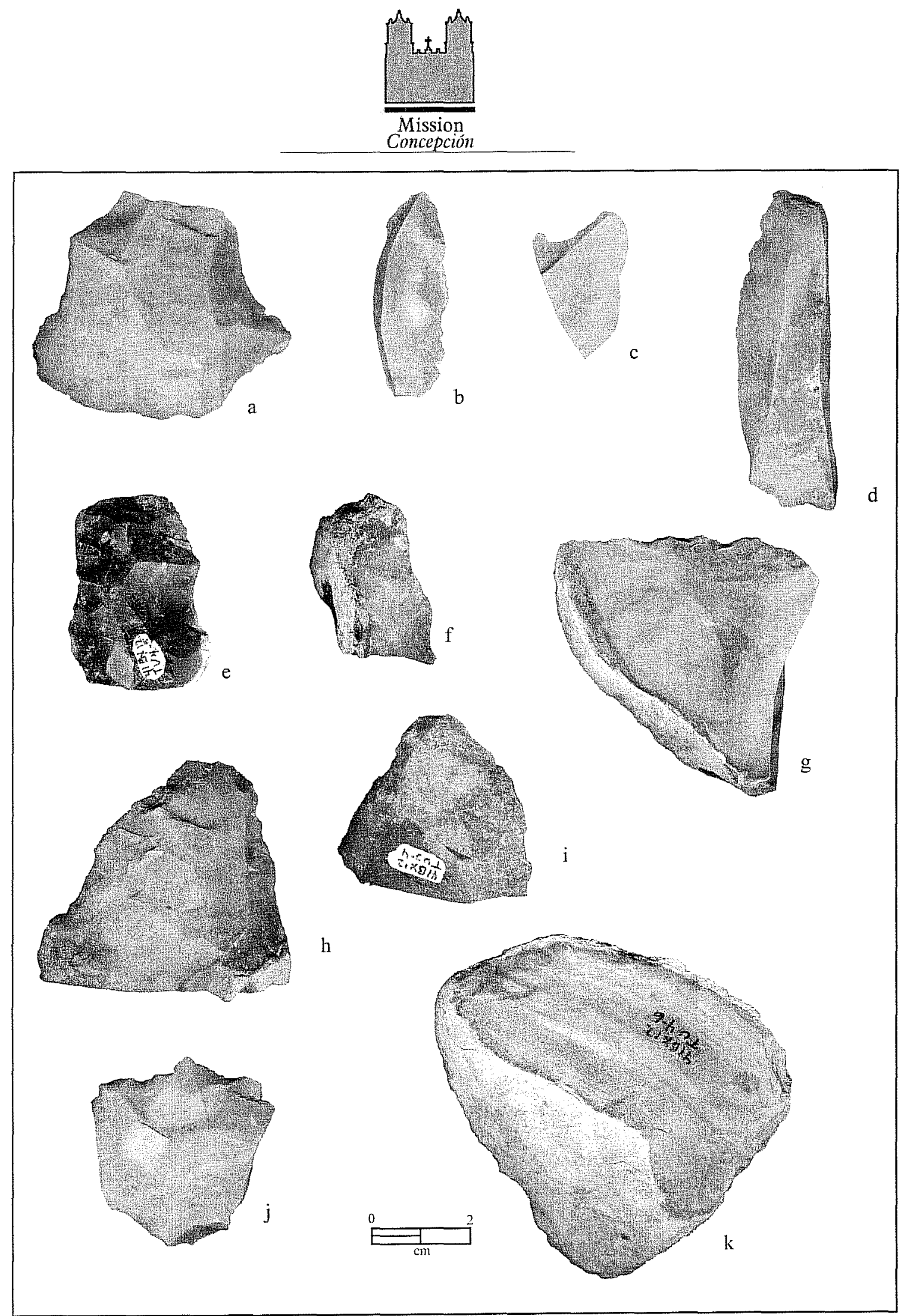

Figure 3-27. Lithic tools: a-c) side scrapers; d) expedient knife; e-g) indeterminate unifaces; $\mathrm{h}-\mathrm{j}$ ) indeterminate bifaces; $\mathrm{k}$ ) core. 


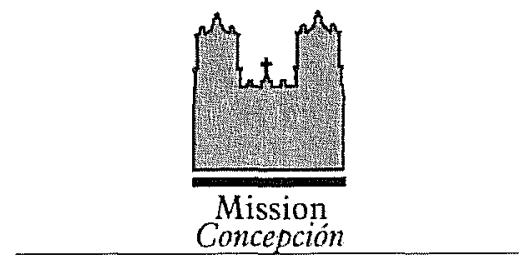

scalloping along the lateral edge derives from cutting or slicing. No retouch is present on the working edge of the expedient tool. The flat longitudinal break-face present behind the working edge may have been intentionally created to provide backing while the tool was in use. However, the use of extreme force during flake removal can also result in the longitudinal splitting of flakes, particularly when hard hammer stones are employed in the removal.

\section{Indeterminate Unifaces}

Three unifacially retouched flake fragments are included in the category (Table 3-6). These specimens represent items that could not be classified into functional tool categories due to their fragmentary nature or lack of use-wear. Two of the specimens are secondary blade fragments with retouch along the margins (Figure 3-27e-f). One of the two may represent a heavily reworked end/side scraper that has been extensively flaked on the ventral surface removing much of the original flake blank ventral face (Figure 3-27e). The third specimen is a large secondary flake fragment with irregular retouch along one margin (Figure $3-27 \mathrm{~g}$ ). It is possible that this specimen represents a side scraper blank broken in manufacture. Only maximum width and thickness could be recorded on these fragmentary specimens.

\section{Core}

A single split pebble core was recovered (Table 3-6). It exhibits two flake removals (Figure 3-27k). One of the two successfully split about a third of the pebble and the second removal appears to have been attempted to split the remaining portion. This removal was unsuccessful. The specimen retains cortex over approximately 80 percent of its surface.

\section{Unmodified Debitage}

Unmodified debitage $(n=56)$ was recovered from the excavations. A provenienced description is curated at the laboratory at CAR. Although, the sample is hardly sufficient to allow broad generalizations, some interesting trends can be noted. The breakdown of cortex categories among the small number of specimens indicates that tertiary flakes dominate the collection (Figure 3-28). Primary and secondary flakes combined represent about 40 percent of the collection. In general, this pattern suggests that the entire reduction sequence took place at the mission and the raw material was not intensively reduced. That is, while raw materials appear to have been introduced as corticate nodules they were not reduced substantially once at the mission.

\section{Indeterminate Bifaces}

Three bifacially flaked fragments are included in this category. Two of the items are pointed distal fragments while the remaining specimen is a medial fragment (Table 3-6). Judging from their thickness ( 16 and $18 \mathrm{~mm}$ ) the two distal fragments appear to be made on either large flake blanks or corticate nodules (Figure 3-27h-i). The medial fragment is made on a tertiary flake blank (Figure 3-27j). All three are manufacture failures and represent early reduction stage bifaces. No use-wear is evident on the fragments.

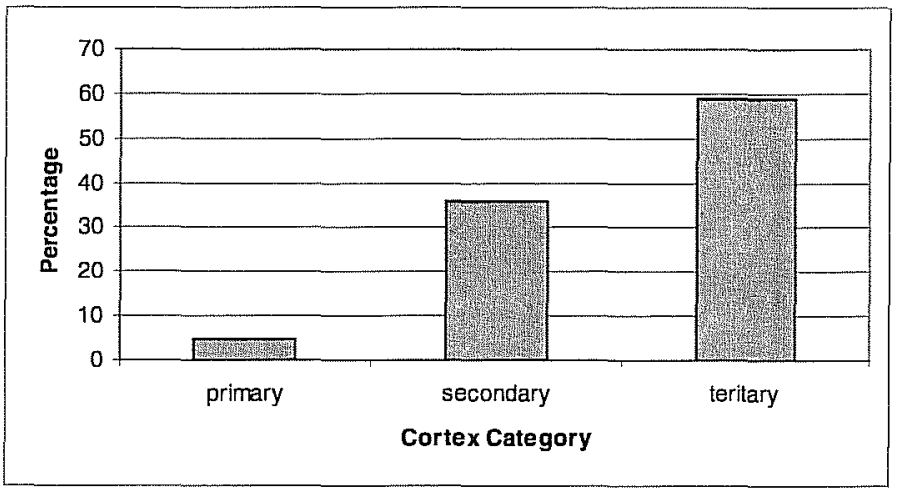

Figure 3-28 . Debitage cortex categories. 


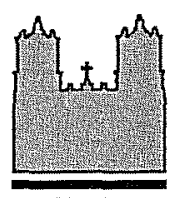

Mission

Concepción

The distribution of debitage by size classes indicates that $11-20 \mathrm{~mm}$ specimens dominate the collection (Figure 3-29). Interestingly, the 21-30 $\mathrm{mm}$ and 31-40 $\mathrm{mm}$ size classes are also relatively common. The smallest size class $(1-10 \mathrm{~mm})$ may be under-represented primarily because of the 1/4-inch hardware cloth used in screening the bulk of the matrix. The size class distributions also suggest that raw materials were not reduced heavily once they arrived at the mission.

Slightly more than half ( $n=33,59$ percent) of the 56 debitage specimens are platform bearing. The distribution of platform facet counts among these specimens indicates that single faceted flakes are the most common (Figure 3-30). Importantly, corticate platforms are the second most common type, further indicating the relative scarcity of flakes with highly prepared platforms. Platform-bearing flakes with two and three or more facets represent a relatively small proportion of the collection. This pattern stands in strong contrast to debitage collections dominated by bifacial reduction, where multi-faceted striking platforms greatly outnumber corticate and single faceted specimens (Tomka 1989).

Ten (18 percent) of the 56 pieces of debitage could not be categorized into flake types. The breakdown of the remainder of the debitage collection indicates that core/platform preparation flakes constitute the largest proportion of the sample (Figure 3-31). Given that a large proportion of the platform-bearing flakes are single faceted or corticate, and a number of the speci-

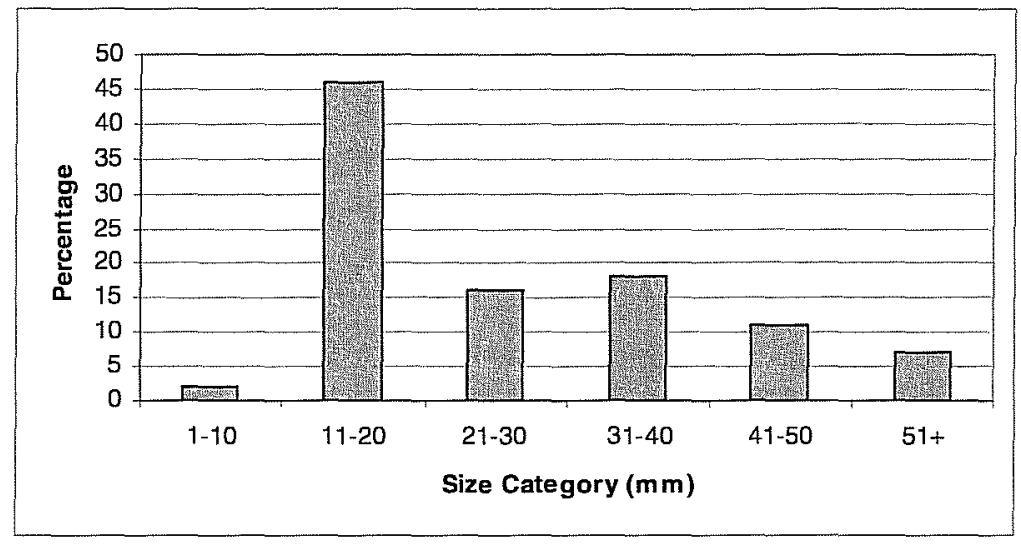

Figure 3-29. Debitage size-class categories.

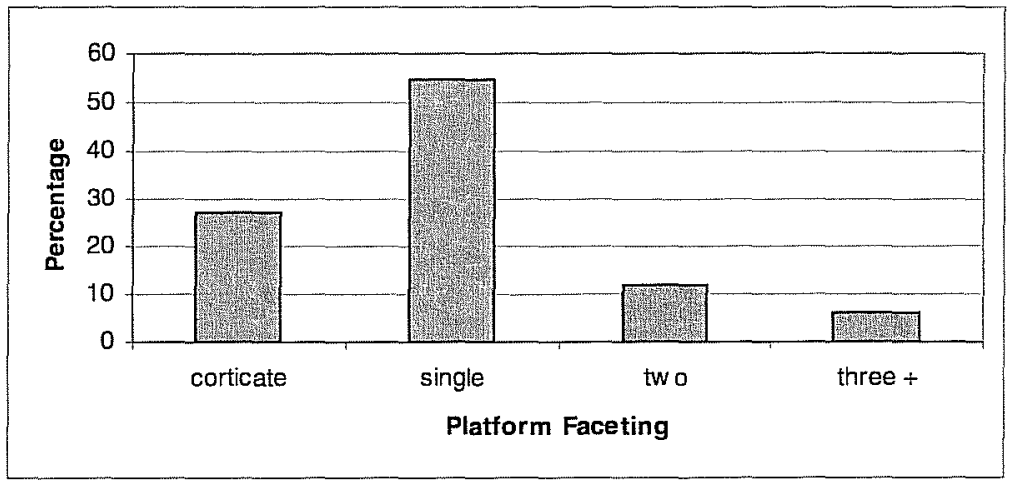

Figure 3-30. Platform faceting categories among platformbearing debitage. 


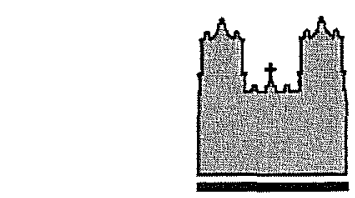

Mission

Concepcion

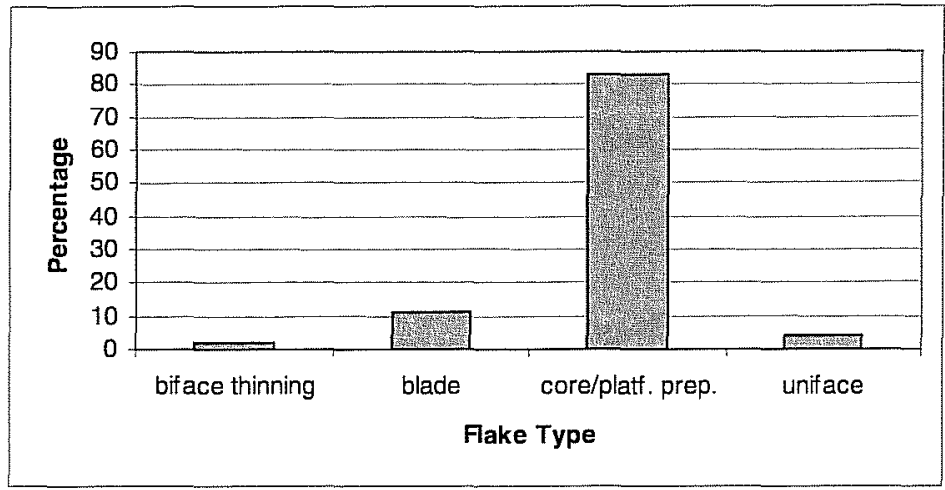

Figure 3-31. Flake types among classifiable debitage.

mens have blade-like morphologies, it is likely that most of these flakes derive from the preparation of uni- or multi-directional cores rather than bifacial core reductions (e.g., the manufacture of bifaces).

Blades constitute the second largest percentage of the debitage, excluding indeterminate flakes and angular debris. Two flakes ( 4 percent) were identified as uniface resharpening flakes in the small collection. Finally, a single flake was identified as a bifacial thinning flake.

The presence of three large biface fragments among the 11 non-debitage items suggests that biface manufacture was a common activity at the site. The near absence of biface manufacture debitage in the small debitage collection is surprising in light of these manufacture broken bifaces. This lack of congruity suggests a number of possibilities:

The bifaces were recycled from Archaic or Late Prehistoric sites;

The bifaces were made in other parts of the site where the debitage assemblage was not sampled;
The flake types were misclassified. Because a large majority of the flakes have single faceted striking platforms, it is not likely that many of these pieces of debitage derive from biface reduction.

Classification error appears to be the least likely possibility and the differing conclusions drawn from the tool and debitage analyses may reflect either inadequate sampling or the recycling of bifaces from $\mathrm{Ar}$ chaic or Late Prehistoric components.

Based on the limited sample size, little can be stated with confidence regarding lithic technology at Mission Concepción from these excavations. The lithic artifacts indicate the procurement of local or nearby raw materials, a tool kit composed primarily of expedient tool forms (e.g., scrapers), and a heavy reliance on blade and/or flake blank production. Bifacial reduction appears to be under-represented in the debitage assemblage, although bifacial artifacts are present in the small collection. This incongruity may indicate the recycling of bifacial artifacts from Prehistoric sites. 


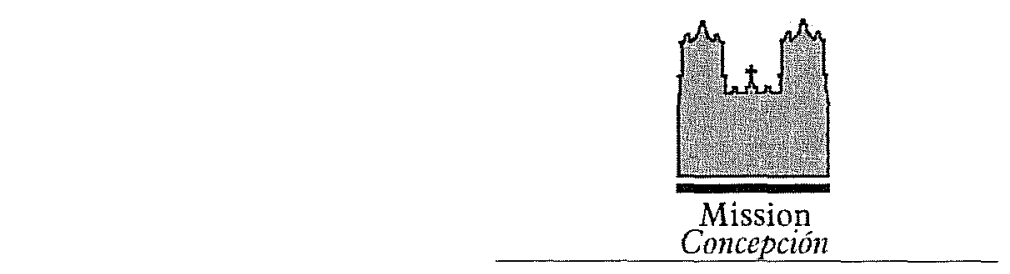

\section{Vertebrate Faunal Remains}

\author{
Barbara A. Meissner
}

A total of 19,795 vertebrate faunal remains, weighing $34,181.95 \mathrm{~g}$, was recovered during the project. In the field, the bone was recovered by screening sediment through 1/4-inch mesh. Bones were bagged with other artifacts by unit and level. In the laboratory, all bone was washed, dried, then bagged by unit and level. The bone was identified to the most specific taxon possible using the comparative collection at CAR, as well as several reference texts (Balkwill and Cumbaa 1992; Boessneck 1970; Gilbert 1990; Hildebrand 1955; Hillson 1986; Olsen 1960, 1964, 1968; Schmid 1972). Identifications were conservative, i.e., bone which appeared to be cow-sized was not identified as Bostaurus unless it could be differentiated from Bison and Equus species. All bone was weighed. Evidence of exposure to heat was noted on all bone. Element, portion of element, side, and evidence of immaturity, gnawing, or pathology were noted on bone identified to the order taxonomic level. When bone could be identified only as mammal, an estimate of the size of the animal was made when possible (Table 3-7).

When analysis was complete, all bones were bagged by taxon, if they were identified to the order taxonomic level, and then by provenience. This collection is stored at the CAR curation facility.

\section{Analysis}

This collection, in general, is highly fragmented, especially the bone from the upper $20 \mathrm{~cm}$ of each Test Unit.

Table 3-7. Taxa identified

\begin{tabular}{|c|c|c|c|}
\hline Taxa & Common Name & Count & Weight (g) \\
\hline Mammalia & Mammals & & \\
\hline Artiodactyl & Deer, sheep, goats & 46 & 131.29 \\
\hline Bison bison & American bison & 11 & 299.33 \\
\hline Bos taurus & Cattle & 202 & 5768.04 \\
\hline Bovinae & Cattle or bison & 493 & 5311.47 \\
\hline Canis sp. & Dog, wolf, or coyote & 20 & 32.71 \\
\hline Capra hircus & Domestic goat & 1 & 3.50 \\
\hline Capra /Ovis & Goat or sheep & 4 & 19.51 \\
\hline Didelphis virginianus & Opossum & 1 & 1.43 \\
\hline Equus sp. & Horse family & 11 & 335.08 \\
\hline Mephitis mephitis & Striped skunk & 1 & 1.49 \\
\hline Neotoma sp. & Woodrats & 5 & 1.43 \\
\hline Odocoileus virginianus & White-tailed deer & 14 & 164.67 \\
\hline Ovis aries & Domestic sheep & 3 & 29.99 \\
\hline Rodentia & Rodents & 6 & 0.98 \\
\hline Sus scrofa & Domestic pig & 2 & 10.75 \\
\hline Sylvilagus sp. & Cottontail rabbit & 1 & 0.11 \\
\hline Taxidea taxus & American Badger & 2 & 3.60 \\
\hline Mammal--very small & Rat, mouse-sized & 5 & 0.71 \\
\hline Marnmal--small & Rabbit-sized & 13 & 7.43 \\
\hline Mammal--medium & Dog-sized & 8 & 12.60 \\
\hline Mammal--large & Deer, sheep-sized & 51 & 170.38 \\
\hline Mammal--very large & Cattle, bison, horse-sized & 2252 & 12489.84 \\
\hline Mammal & Size indeterminate & 16388 & 9102.06 \\
\hline & Total Mam & 19540 & 33898.4 \\
\hline
\end{tabular}




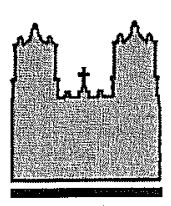

Mission

Concepción

Table 3-7. Taxa identified continued...

\begin{tabular}{|l|l|r|r|}
\hline \multicolumn{1}{|c|}{ Taxa } & \multicolumn{1}{|c|}{ Common Name } & Count & Weight (g) \\
\hline Aves & Birds & 11 & 5.09 \\
\hline Anas sp. & Ducks & 1 & 0.22 \\
\hline Anatidea & Ducks, Geese & 4 & 6.21 \\
\hline Branta canadensis & Canadian goose & 6 & 4.35 \\
\hline Gallus domesticus & Chicken & 5 & 9.59 \\
\hline Meleagris gallopavo & Turkey & 2 & 0.66 \\
\hline Tyto alba & Barn owl & 51 & 28.66 \\
\hline Aves & Size indeterminate & $\mathbf{8 0}$ & $\mathbf{5 4 . 7 8}$ \\
\hline & & & \\
\hline Reptilia & Toptal Birds & 1 & 33.25 \\
\hline Alligator alligator & Alligator & 2 & 0.82 \\
\hline Crotalus atrox & West. diamondback rattlesnake & 18 & 63.02 \\
\hline Pseudomys sp. & Pond sliders & 14 & 27.81 \\
\hline Trionyx sp. & Softshelled turtles & 15 & 11.07 \\
\hline Testudinata & Turtles & $\mathbf{1 3 5 . 9 7}$ \\
\hline & & $\mathbf{5 0}$ & 22.56 \\
\hline Ictalunus sp. & Catlish & 30 & 1.02 \\
\hline Lepisosteus sp. & Gars & 3 & 14.82 \\
\hline Pylodictus olivaris & Bullhead catfish & 26.88 \\
\hline Osteichthyes & Unidentified fish & $\mathbf{6 3}$ & $\mathbf{6 5 . 2 8}$ \\
\hline & & $\mathbf{8 3}$ & $\mathbf{2 7 . 5 2}$ \\
\hline Vertebrata & Tnidentified bone & $\mathbf{3 4 1 8 1 . 9 5}$ \\
\hline & & $\mathbf{1 9 7 9 5}$ & \\
\hline
\end{tabular}

During excavation, much of the bone in the upper levels was in large, potentially identifiable pieces, however, this bone was usually found to be completely shattered in situ. Condition of the bone improved somewhat in lower levels, and average bone size steadily increased as digging progressed (Table 3-8). However, even in the lowest levels, much of the bone was either in very small pieces or could not be excavated without breaking into unidentifiable fragments. The average bone weight for the entire collection was only $1.7 \mathrm{~g}$. Ninety-five percent of the bone could be identified only as mammalian. Only 376 bones (1.9\%) could be identified to the genus taxonomic level.

Table 3-8. Count, Weight, and Average Bone Weight for each Test Unit Level

\begin{tabular}{|l|r|r|r|r|}
\hline \multirow{2}{*}{} & \multicolumn{4}{|c|}{ Levels } \\
\cline { 2 - 5 } & \multicolumn{1}{|c|}{$\mathbf{1}$} & \multicolumn{1}{c|}{$\mathbf{2}$} & \multicolumn{1}{c|}{$\mathbf{3}$} & \multicolumn{1}{c|}{4} \\
\hline Count & 2118 & 7597 & 6493 & 1568 \\
\hline Weight (g) & 1841.97 & 9755.71 & 10733.09 & 4488.62 \\
\hline Average & 0.87 & 1.28 & 1.65 & 2.86 \\
\hline
\end{tabular}

Twenty-five taxa were identified to at least the genus level in the collection. A list of identified taxa is shown in Table 3-9, with counts and weights. A complete provenienced list of all data recovered from the bone is curated at the laboratory at CAR.

\section{Heat Alteration}

Evidence of exposure to heat can indicate whether bone was thrown into fire as a routine disposal method. Only 0.8 percent $(n=168)$ of the bone showed evidence of heat alteration. This small percentage indicates that bone was burned only incidentally.

\section{Butcher Marks}

This collection is too fragmented to allow useful examination of butchering practices as evidence of butchering and other tool marks were identified on only 85 bones ( 0.4 percent). Five bones displayed more than 1 type of butcher mark. Table 3-10 lists the type of 


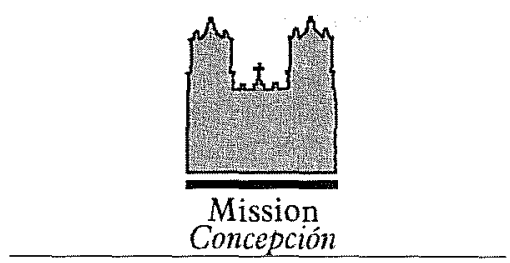

Table 3-9. Bone Identified to the Genus Taxonomic Level

\begin{tabular}{|c|c|c|c|c|c|}
\hline Taxa & Common Name & Count & $\%$ & Weight (g) & \\
\hline Mammalia & Mammals & & & & \\
\hline Bison bison & American bison & 11 & $2.9 \%$ & 299.33 & $4.4 \%$ \\
\hline Bos taurus & Cattle & 202 & $53.7 \%$ & 5768.04 & $84.3 \%$ \\
\hline Canis sp. & Dog, wolf, or coyote & 20 & $5.3 \%$ & 32.71 & $0.5 \%$ \\
\hline Capra hircus & Domestic goat & 1 & $0.3 \%$ & 3.50 & $0.1 \%$ \\
\hline Didelphis virginianus & Opossum & 1 & $0.3 \%$ & 1.43 & $0.0 \%$ \\
\hline Equus sp. & Horse family & 11 & $2.9 \%$ & 335.08 & $4.9 \%$ \\
\hline Mephitis mephitis & Striped skunk & 1 & $0.3 \%$ & 1.49 & $0.0 \%$ \\
\hline Neotoma sp. & Woodrats & 5 & $1.3 \%$ & 1.43 & $0.0 \%$ \\
\hline Odocoileus virginianus & White-tailed deer & 14 & $3.7 \%$ & 164.67 & $2.4 \%$ \\
\hline Ovis aries & Domestic sheep & 3 & $0.8 \%$ & 29.99 & $0.4 \%$ \\
\hline Sus scrofa & Domestic pig & 2 & $0.5 \%$ & 10.75 & $0.2 \%$ \\
\hline Svlvilagus sp. & Cottontail rabbit & 1 & $0.3 \%$ & 0.11 & $0.0 \%$ \\
\hline Taxidea taxus & American Badger & 2 & $0.5 \%$ & 3.60 & $0.1 \%$ \\
\hline & Total Mammals & 274 & $72.9 \%$ & 6652.13 & $97.2 \%$ \\
\hline Aves & Birds & & & & \\
\hline Anas sp. & Ducks & 11 & $2.9 \%$ & 5.09 & $0.1 \%$ \\
\hline Branta canadensis & Canadian goose & 4 & $1.1 \%$ & 6.21 & $0.1 \%$ \\
\hline Gallus domesticus & Chicken & 6 & $1.6 \%$ & 4.35 & $0.1 \%$ \\
\hline Meleagris gallopavo. & Turkey & 5 & $1.3 \%$ & 9.59 & $0.1 \%$ \\
\hline Tyto alba & Barn owl & 2 & $0.5 \%$ & 0.66 & $0.0 \%$ \\
\hline & Total Birds & 28 & $7.4 \%$ & 25.9 & $0.4 \%$ \\
\hline Reptilia & Reptiles & & & & \\
\hline Alligator alligator & Alligator & 1 & $0.3 \%$ & 33.25 & $0.5 \%$ \\
\hline Crotalus atrox & West diamondback rattlesnake & 2 & $0.5 \%$ & 0.82 & $0.0 \%$ \\
\hline Pseudomws sp. & Pond sliders & 18 & $4.8 \%$ & 63.02 & $0.9 \%$ \\
\hline Trions $\mathrm{sp}$. & Softshelled turtles & 14 & $3.7 \%$ & 27.81 & $0.4 \%$ \\
\hline & Total Reptiles & 35 & $9.3 \%$ & 124.9 & $1.8 \%$ \\
\hline Osteicthves & Boney Fish & & & & \\
\hline Ictalurus sp. & Catifish & 30 & $8.0 \%$ & 22.56 & $0.3 \%$ \\
\hline Lepisosteus sp. & Gars & 3. & $0.8 \%$ & 1.02 & $0.0 \%$ \\
\hline Pylodictus olivaris & Bullhead catfish & 6 & $1.6 \%$ & 14.82 & $0.2 \%$ \\
\hline & Total Fishes & 39 & $10.4 \%$ & 38.40 & $0.6 \%$ \\
\hline & Overall Totals & 376 & $100.0 \%$ & 684133 & $100.0 \%$ \\
\hline
\end{tabular}

mark and the number of bones on which the mark was observed. No bones were found with saw marks. Marks that are the result of removing meat from bones (thin and thick cuts) are only 4.7 percent of the marks observed, while signs of earlier stages of butchering (chops and impact scars), are 95 percent of the marks.

Table 3-10. Butcher Marks Observed on Bone

\begin{tabular}{|c|c|c|}
\hline Butcher Mark Type & Count & $\%$ \\
\hline Thin cut (knife) & 3 & $3.5 \%$ \\
\hline $\begin{array}{l}\text { Thick Cut (Large knife or } \\
\text { cleaver, superficial) }\end{array}$ & 1 & $1.2 \%$ \\
\hline Chop (Deep) & 58 & $68.2 \%$ \\
\hline Impact scar & 23 & $27.1 \%$ \\
\hline Total & 85 & $100.0 \%$ \\
\hline
\end{tabular}

\section{Pathology}

Evidence of pathology was infrequent in this collection, as is often the case in Colonial fauna collections. All pathologies observed were on cattle bone. Two $2+3$ carpals, a $2+3$ tarsal, and a proximal metacarpal showed evidence of moderate arthritic changes. One metatarsal had patches of small pits, evidence of some type of inflammation, along its diaphysis. One $2+3$ tarsal appeared to have a congenital malformation. The fifth metatarsal, the remnant of which is sometime present in artiodactyls, is fused to the posterior end.

The most interesting pathology is a fourth carpal, which shows evidence of an invasive process, apparently a tumor, which has obliterated the normal 


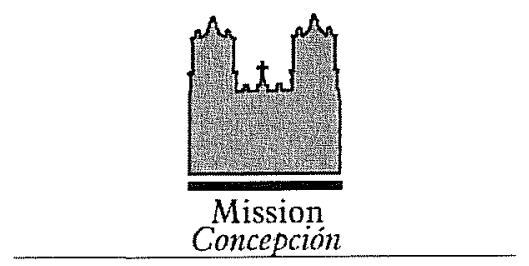

articulation with the intermediate carpal (Figure 3-32a) and was beginning to show proliferation to the distal surface (Figure 3-32b). The articulation with the ulnar carpal was apparently still at least partially functional (arrows in Figure 3-32a).

\section{Results}

The number of taxa identified in this collection is somewhat smaller than is usually seen in mission sites. The highly fragmented nature of the collection could be responsible, however medium to small animals such as raccoons, squirrels, and cotton rats, usually found at Colonial sites were not present. Although smaller bones are more subject to most taphonomic factors than larger bones (Von Endt and Ortner 1984), this is not true of the more mechanical stresses caused by compression, and by excavation. Medium, small and very small-sized mammals constitute only 0.1 percent of the unidentifiable mammal bone present in the collection. It seems, therefore, that this assemblage is somewhat less diverse than is usually seen in Colonial bone collections. The animals in question, however, never form a significant part of the Colonial diet.

Cattle dominate the identifiable assemblage, constituting 53.7 percent of the total Number of Identified Specimens (NISP). Goats, sheep, and pigs constitute only 2 percent, while wild mammals often hunted for food, including bison, deer, rabbit, and opossum account for 7.2 percent of the total. Birds commonly used as food, i.e., geese, turkey, and chicken, were 7.4 percent of the total, and identified fish were 10.4 percent. Identified turtle remains were 8.5 percent of the total NISP. These figures, however, give a false

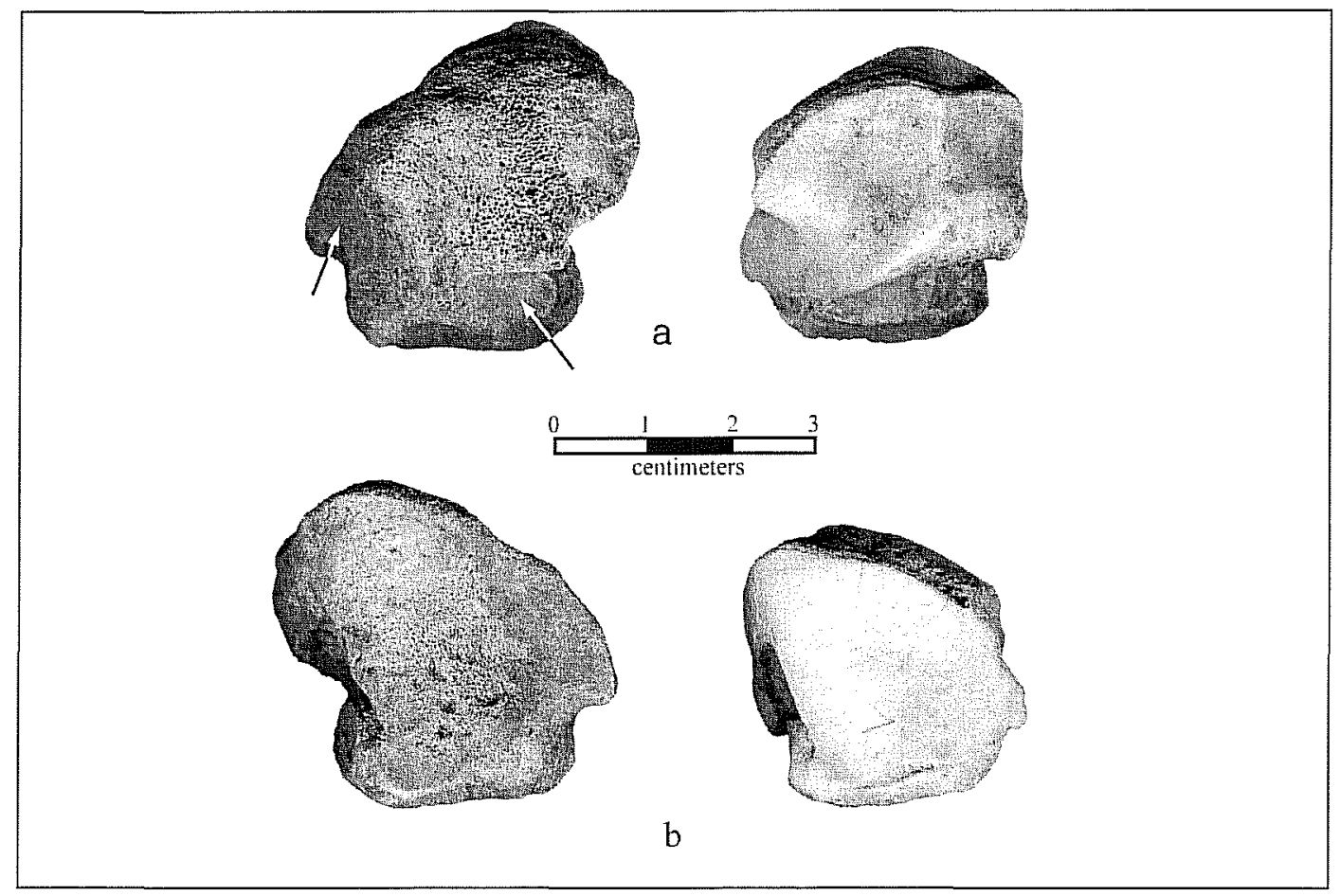

Figure 3-32. Two views of a diseased carpal of a cow (left), compared to a normal specimen from the comparative collection (right): a) proximal surface; b) distal surface. 


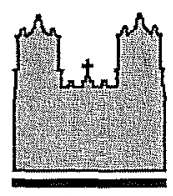

Mission

Concepción

impression of the importance of species with smaller body weight. Bone weight is, in general, a better indicator of relative dietary importance (as opposed to relative abundance) than NISP, but this measure must be used with some caution. In general, larger bones carry more meat, but the relationship is not linear (Reitz and Scarry 1985:18) and varies among different taxa. Also, there is considerable variation from one part of the animal to another (e.g., lower legs of cattle are dense, heavy bones but carry relatively little meat compared to other bones of the body). Table 3-11 shows the percentage of total NISP weight for each of the categories listed in the paragraph above. Data from five other faunal collections from San Antonio missions are included for comparison.

The importance of cattle in the mission diet has been demonstrated repeatedly (deFrance 1999; Hunziker 1998;Meissner 1998, 1999a, 1999b, 1999c). This phenomenon is very apparent in examining Table $3-11$, which shows a consistent pattern of 76 to 87 percent of the total NISP weight in each project coming from cattle bone. This is also apparent in an analysis of bones from Mission Espíritu Santo de Zuñiga (41GD1) and Mission Nuestra Señora del Rosario (41GD2) in Goliad County, recently published by deFrance (1999). For comparison with the San Antonio missions, the percentage of total NISP bone weight was calculated for the taxa categories seen in Table 3-11, using data from Tables 3, 4, 5 and 6 in deFrance (1999:177-179). deFrance (1999:182,184) did not differentiate between Bison and Bos, but believes that the nature of the elements represented, as well as the measurements of these elements, indicates on-site butchering of cattle rather than return of hunted bison to the site. For this reason, deFrance's category Bos/Bison was assumed to be $B o s$ for the purposes of the comparison. The results are shown in Table 3-12.

Table 3-11. Percent of Total NISP Bone Weight for Selected Taxa at San Antonio Missions Data are from the current project and 5 other projects at 3 other missions.

\begin{tabular}{|c|c|c|c|c|c|c|c|c|}
\hline \multirow[b]{2}{*}{ Taxa Category } & Concepción & Valero & San Juan & \multicolumn{3}{|c|}{ San Jose } & \multirow[b]{2}{*}{ Average } & \multirow[b]{2}{*}{ STD } \\
\hline & $\begin{array}{l}\text { Current } \\
\text { project }\end{array}$ & $\begin{array}{c}\text { Meissner } \\
(1999 \mathrm{a}: 295)\end{array}$ & In prep. & $\begin{array}{l}\text { Hunziker } \\
(1998: 23)\end{array}$ & $\begin{array}{l}\text { Meissner } \\
(1998: 36) \\
\end{array}$ & $\begin{array}{c}\text { Meissner } \\
(1999 \mathrm{~b}: 42)\end{array}$ & & \\
\hline Cattle & $84.3 \%$ & $76.2 \%$ & $80.2 \%$ & $87.9 \%$ & $76.0 \%$ & $78.0 \%$ & $80.4 \%$ & $4.4 \%$ \\
\hline Goats, sheep, and pigs & $0.6 \%$ & $1.6 \%$ & $4.4 \%$ & $1.4 \%$ & $6.3 \%$ & $6.3 \%$ & $3.4 \%$ & $2.3 \%$ \\
\hline Wild mammals hunted for food & $6.8 \%$ & $21.2 \%$ & $4.7 \%$ & $7.9 \%$ & $6.3 \%$ & $12.2 \%$ & $9.8 \%$ & $5.6 \%$ \\
\hline Birds used for food & $0.4 \%$ & $0.5 \%$ & $1.0 \%$ & $0.6 \%$ & $1.1 \%$ & $0.4 \%$ & $0.7 \%$ & $0.3 \%$ \\
\hline Fish & $0.6 \%$ & $0.5 \%$ & $0.4 \%$ & $<0.1 \%$ & $0.8 \%$ & $0.1 \%$ & $0.5 \%$ & $0.2 \%$ \\
\hline Turtles & $1.3 \%$ & $0.2 \%$ & $1.7 \%$ & $0.1 \%$ & $1.5 \%$ & $2.4 \%$ & $1.2 \%$ & $0.8 \%$ \\
\hline
\end{tabular}

Table 3-12. Percent of Total NISP Bone Weight for

Selected Taxa at Two Goliad Missions

(Based on data from deFrance 1999)

\begin{tabular}{|l|r|r|}
\hline \multicolumn{1}{|c|}{ Taxa Category } & Rosario & Espritu Santo \\
\hline Cattle & $93.3 \%$ & $90.9 \%$ \\
\hline Goats, sheep, and pigs & $0.6 \%$ & $1.2 \%$ \\
\hline Wild mammals hunted for food & $4.1 \%$ & $5.5 \%$ \\
\hline Birds used for food & $0.7 \%$ & $0.4 \%$ \\
\hline Fish & $<0.1 \%$ & $0.5 \%$ \\
\hline Turtles & $0.6 \%$ & $0.4 \%$ \\
\hline
\end{tabular}




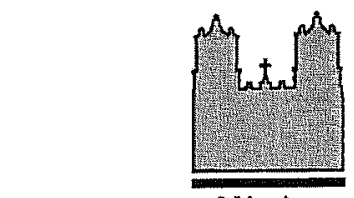

Mission

Concepción

The data from the Goliad missions seems to indicate a stronger reliance on cattle compared to the San Antonio missions. However, the lack of differentiation of Bos and Bison means that, although the majority of bovid bone is probably Bos, there could be a few Bison elements represented. If this is the case, then the mission diet in San Antonio and Goliad are essentially the same. In any case, it is clear that, at least in the collections used in this comparison, there is little variation from one mission to another. Cattle dominate the diet, with only a few other domestic animals present and some hunting of wild animals indicated.

The bone in this acequia seems to be primarily the result of disposal of unwanted portions of cattle. Together, the carpals, tarsals, metapodials and phalanges of Bos constituted 67 percent of the total elements identified (136/202). This certainly does not mean that 67 percent of the bone that was originally thrown into the acequia was lower legs. Again, these elements are some of the most dense in the body, but do not carry a great deal of meat, so not only are they less likely to be broken up by cultural practices, but they are more likely to survive burial in identifiable condition. These factors unquestionably bias the identifiable bone counts in favor of these elements and it is difficult to make any kind of objective adjustment for this bias. However, the presence of at least three articulated cow feet in the collection (including a total of 32 bones) does indicate that unwanted (and unprocessed) butchering remains were being thrown into the acequia. The relatively low number of other species suggests that the area was primarily used for that purpose, although certainly other garbage, including both lithics and ceramics, were also tossed there.

Unfortunately, the highly fragmented nature of this collection, and the resultant low percentage of taxa identified to the genus level, does not permit other inferences to be drawn from the bone, and requires us to consider the inferences discussed to be viewed with caution. Although the heavy dependence on cattle by Mission Concepción residents is readily apparent, the need to better understand butchering practices, as well as the relative importance of animals other than cattle, makes faunal remains from Colonial sites of particular importance.

\section{Discussion}

Examination of previous reports describing archaeological work at Concepción for evidence of acequias leaves a confusing impression. Figure 3-33 shows the locations of acequias or possible acequias described by archaeologists. The location of a previously unsuspected acequia segment beneath Felisa Street, and more importantly, the recognition that this acequia had been filled during the Colonial period allows us to begin the process of sorting out the history of acequia construction around the mission.

Ivey and Fox (1999:16-20, 23-31) believe that there was an early acequia which ran from just north of the present church to the southwest and exited the mission compound roughly in the area where the south gate was later constructed. They believe this acequia was associated either with the first location of Mission San José or with the failed Mission San Francisco Xavier de Nájera (Ivey and Fox 1999:45) This acequia seems to have been abandoned and later used as a trash dump before Mission Concepción was moved to this location (Ivey and Fox 1999:46).

The report of Fray Francisco Ortiz, in 1745, describes the acequia at Mission Concepción:

"Riega de tierras una buena azequia, que passa por medio de el Pueblo.

(Watering the fields is a good acequia, which passes through the middle of the pueblo)"

(Visita de las Missiones hecha de orden de H. M. P. Comm.o Gr.al Fr. Juan Fogueras por el P. Fr. Fran.co Xavier Ortiz, en el año de 1745.

Microfilm copy in the Old Spanish Missions Historical Research Library. Our Lady of the Lake University, San Antonio, Texas). 


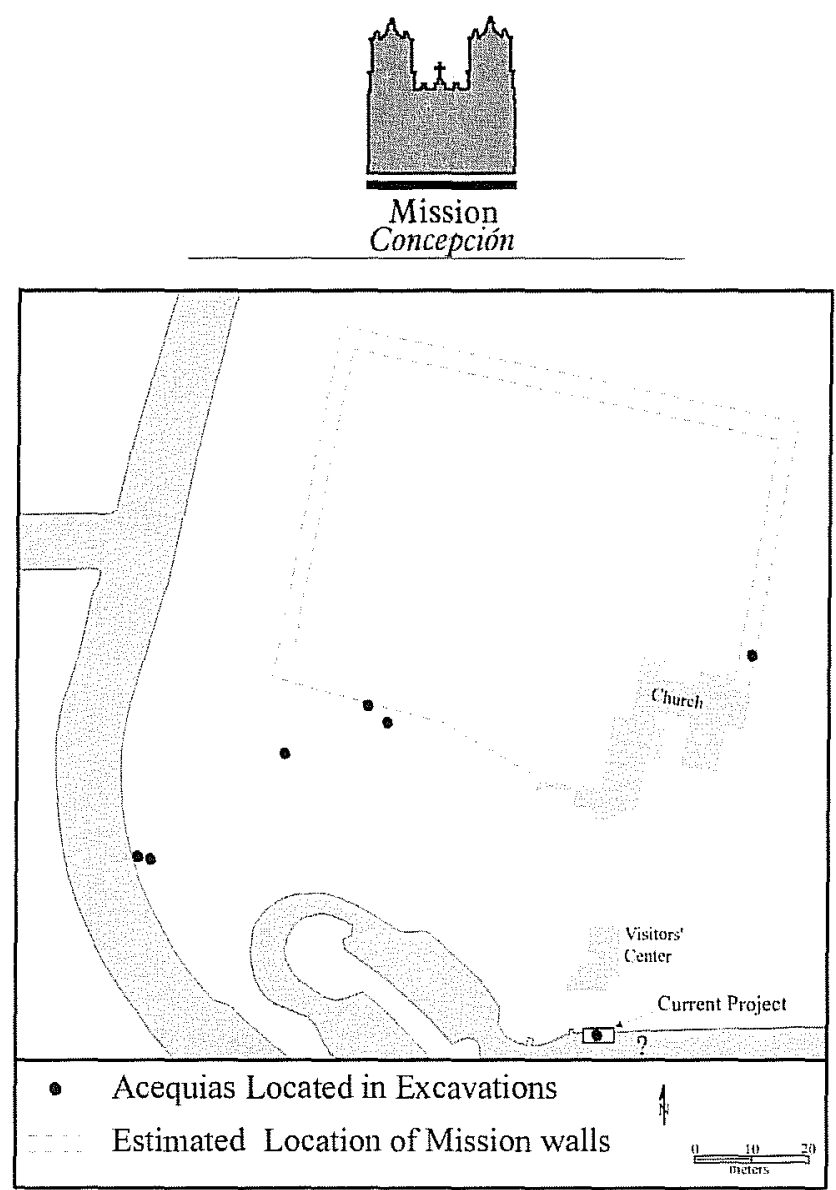

Figure 3-33. Map of Mission Concepción locations where acequias have been encountered during archaeological projects.

Habig (1968a:140) shows this acequia flowing more or less north-south in his reconstruction of the mission, but he admits that this is conjecture. The important point is that the acequia located during this project probably did not run through the mission compound. Test excavations directly north of Felisa Street (Figure 3-8), including unpublished monitoring of construction work beneath the Visitors' Center (A. Fox, personal communication, 1999), have never shown signs of an acequia leading from the current project area into the mission compound. On the other hand, the "old ditch" recorded in nineteenth century deed records, and the location of an acequia aligned with this ditch (Labadie 1989; Figure 4; and Figure 3-8), makes it likely that the acequia led from the main Concepción or "Pajalache" acequia through the project area to the "old ditch" and on west to the San Antonio River. If this is true, then this acequia did not, as Ortiz described, run "por medio de el Pueblo".
The acequia encountered in the current project was filled during the Colonial period, as shown by the large number of Colonial ceramics and the absence of later artifacts below $10 \mathrm{~cm}$. Ortiz' description, the other acequias encountered in archaeological context, their locations, and the fact that the western portion of the "old ditch" was apparently still in at least partial use in the nineteenth century all suggest that the acequia recorded in this project was re-routed, probably before Ortiz saw the mission in 1745. At that time, construction of the new church (the present building) was well underway (Ivey et al. 1990) which, possibly explains the construction debris used to refill this portion of the acequia. By putting together descriptions of the various acequia sections examined archaeologically, and considering Ortiz' description, an estimate of the history of acequia construction and re-construction can be made (Figure 3-34). Figure 3-34 should be considered only a suggestion. Additional work on the acequias will be needed before routes and dates of acequia construction at Concepción will be known with any certainty. 

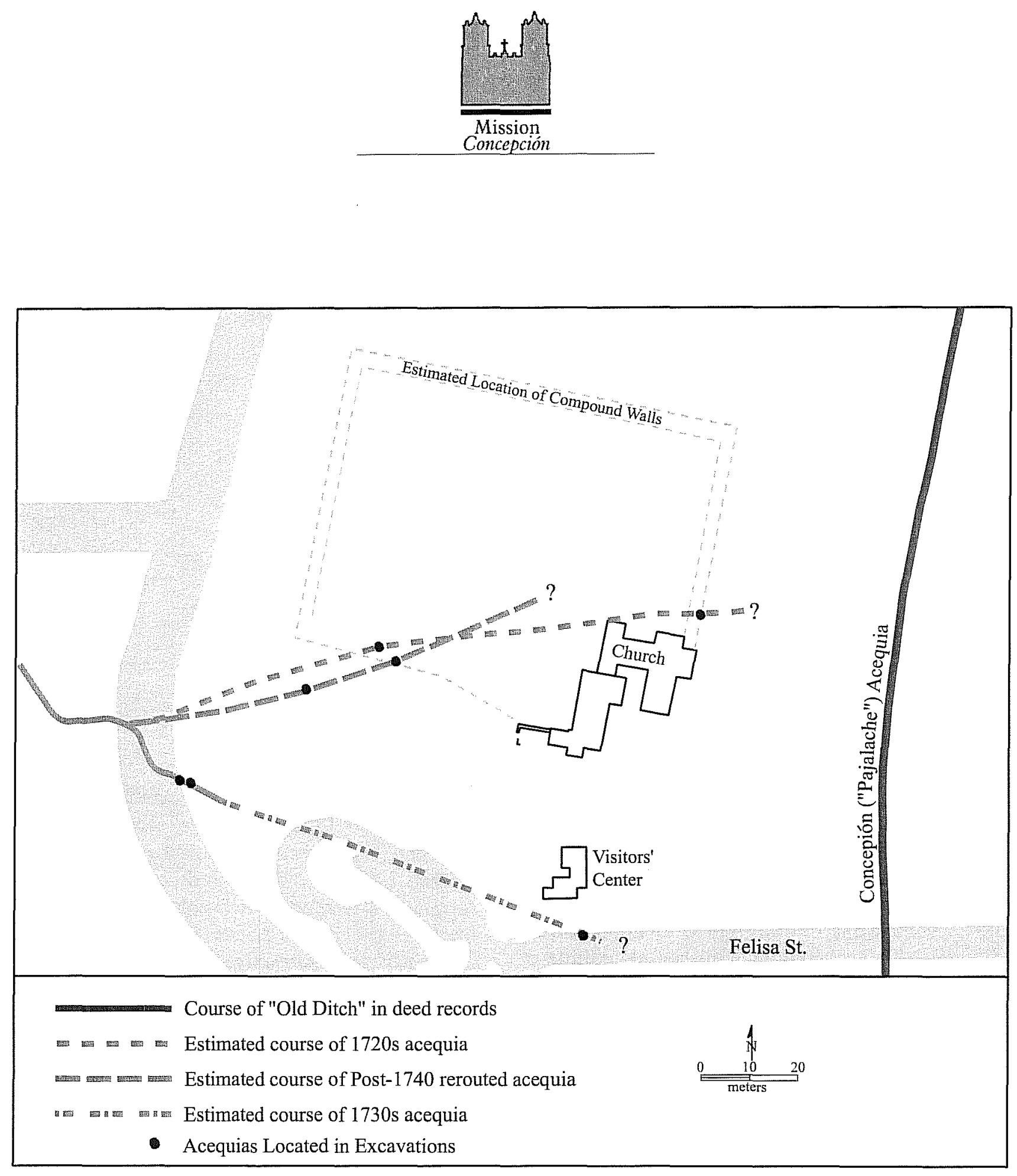

Figure 3-34. Suggested routes and dates of acequias in the vicinity of Concepción. 


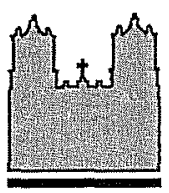

Mission

Concepción

\section{Conclusions}

During construction of a manhole, as part of the Mission Trails Underground Conversion Project, a City Public Service construction crew accidentally impacted a large feature. This feature was later determined to be a segment of an acequia. Archaeologists tested this feature, digging four Test Units adjacent to the pit and profiling the pit walls.

Artifacts in the upper layers of this filled acequia indicated that it had been filled during the Colonial period. The filling appears to have been done in at least two episodes, beginning with the dumping of large amounts of construction debris, followed by a period in which natural accumulation of sediments occurred. At a later date, the area was used as a dump in which a large number of animal bone, as well as other trash, was deposited.

The encounter with this segment of acequia, as well as the determination that it was filled in the Colonial period, provides important clues to the history of the construction of the acequia system near Mission Concepción.

\section{Summary and Recommendation}

This project has shown the value of cooperation between agencies performing construction work near important historic sites and demonstrates how City and State preservation offices, and cultural resource management agencies can work together. Although the location of the feature came as a surprise, the construction crew acted correctly by notifying CPS immediately. CPS, in turn, notified the appropriate authorities and arrangements for testing and/or mitigation of this feature were made as soon as possible. The result is that information about an important part of the archaeology of Mission Concepción has been added to the data already accumulated.
At the time the fieldwork on this project was completed, CAR recommended that construction of all remaining trenches in the Felisa Street/Mission Road area be monitored by archaeologists. As a result, a segment of Colonial wall was identified northeast of the project area (see Appendix A (Concepción).

This project illustrates, once again, the importance of monitoring all construction work near a mission. The details of the architectural history of these missions is not as well understood as was once believed, and such construction work allows us to gain valuable information about the unknown portions of that history. Even in areas where it is believed that previous activities have destroyed important historic remains, some areas of minimally disturbed deposits may still be found. In the process of planning any project near a historic site, such as Mission Concepción, consideration must be given to testing and/or monitoring such work in order to mitigate any negative impact to cultural resources. 


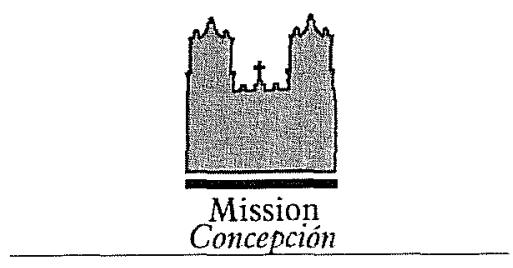

\title{
Appendix A3: Concepción
}

\section{Monitoring Electrical Conduit Trenching at Mission Concepción}

\author{
Rick C. Robinson
}

\section{Introduction}

In March 1999, at Mission Concepción, City Public Service (CPS) unearthed a Mission period acequia feature while digging a manhole for their Mission Trails Underground Conversion Project (MTUC) on Felisa Street, just south of the Concepción Visitors' Center. As a result, it was determined that a staff archaeologist from the Center for Archaeological Research (CAR) should be present to monitor the digging of electrical conduit trenches along Felisa Street and Mission Road.

The monitoring project began April 27, 1999 and ended on May 10, 1999, for a total of ten fieldwork days. Barbara A. Meissner was project archaeologist while Robert J. Hard served as principal investigator. All artifacts, photographs, and field notes related to this project are curated at CAR, located at The University of Texas at San Antonio (UTSA).

\section{Monitoring}

To eliminate the need for aboveground electrical poles on the Mission Concepción compound the construction firm of L. E. Myers Company excavated a series of backhoe trenches. These trenches were designed to hold multiple electrical conduits to replace the aboveground poles. The monitoring portion of the project consisted of overseeing the trenching activities. The trenches were located on both sides of the western end of Felisa Street, connecting to the manhole which had been previously excavated (see Figure 3-8). Also, another trench was located east of the manhole extending north into the grounds of the
Integrated Family Rehabilitation Center (IFRC) building, situated east of the Visitors' Center.

The trenches on Felisa Street continued to the corner of Mission Road, where they turned to the south in front of St. Peter's and St. Joseph's Orphanage, and continued on both sides of Mission Road. They ranged in width from $69-78 \mathrm{~cm}$, and in depth from $1-2.10 \mathrm{~m}$ with the deepest trenches being located on Mission Road. Once excavated, multiple polymerized vinyl

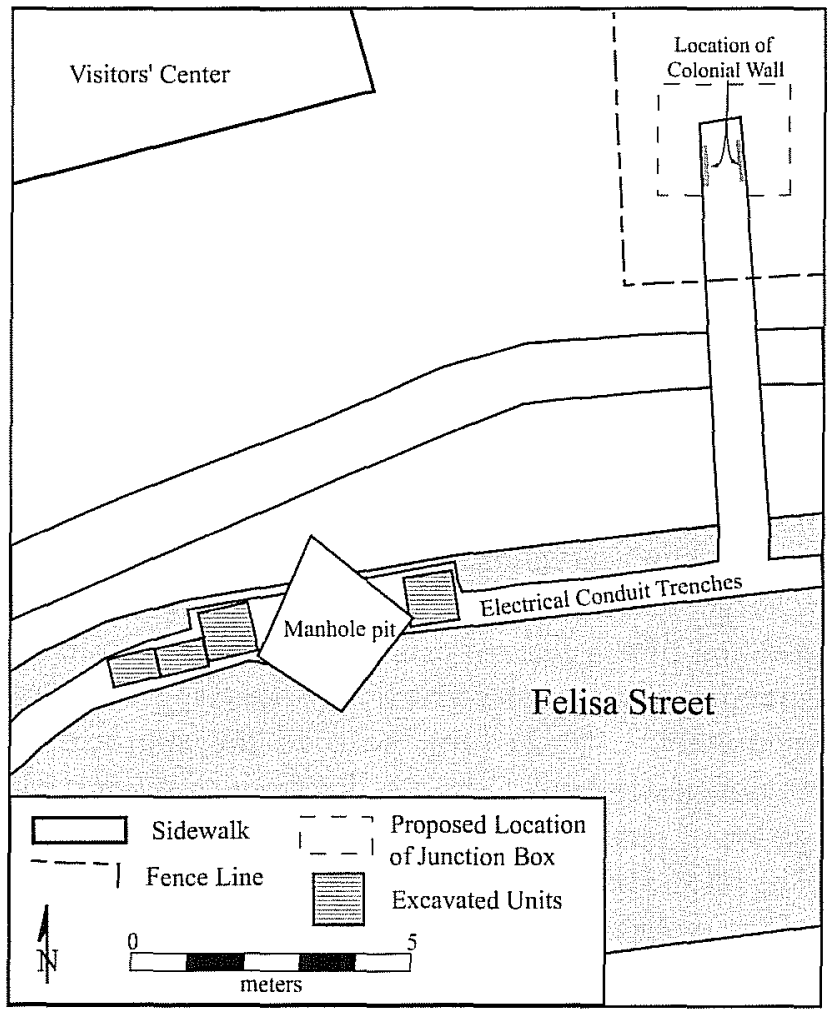

Figure A3-1. Location of Colonial wall northeast of the manhole pit. 


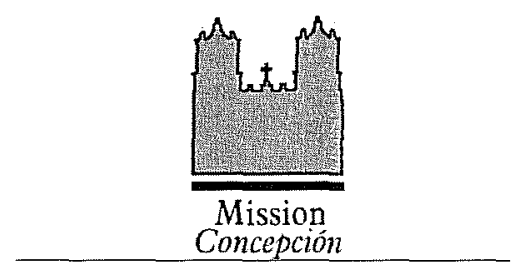

compound (PVC) conduits designed to hold the below-ground electrical wiring were placed inside. The trenches were then filled with a "flowable" cement, and finally the road surface was repaved with asphalt.

\section{Results}

The trenches that border Felisa Street and Mission Road revealed no definable archaeological deposits. Some artifacts, numerous pipes, including water, gas, and sewage lines, were exposed in the trenches but all were dateable to the modern era. The greatest concentration of these existing pipelines occurred on Felisa Street.

Excavation of the trenches on Mission Road revealed a layer of dark brown clay loam, that averaged 1$1.20-\mathrm{m}$ thick above the caliche/limestone bedrock. On both sides of Felisa Street heavily disturbed profiles, due to the number of pipes already present, were exposed. The profiles on Felisa Street show an asphalt/ road base layer that is $26 \mathrm{~cm}$ in depth; overlying a medium brown clay/caliche mixed soil that ranges from ca. $34-60 \mathrm{~cm}$ in thickness, beneath which is the underlying caliche bedrock.

No intact cultural deposits were observed near the acequia feature described in this report. Profiles of the trenches which continued beyond Test Unit 2 on the east and Test Unit 4 on the west indicated that no further Colonial period features or deposits were present (see Figure 3-8).

However, in the trench which ran north into the IFRC grounds (Figures A3-1 and A3-2), several features, including an intact Colonial wall foundation were present. When the initial trench was excavated to the required depth; the profile was then examined before further widening of the trench was continued. In the east and west wall profiles the remnants of a Colonial wall foundation were clearly exposed (Figure A3-3). All excavations were terminated and the offices of CPS, THC, and the San Antonio Office of Historic Preservation were contacted.

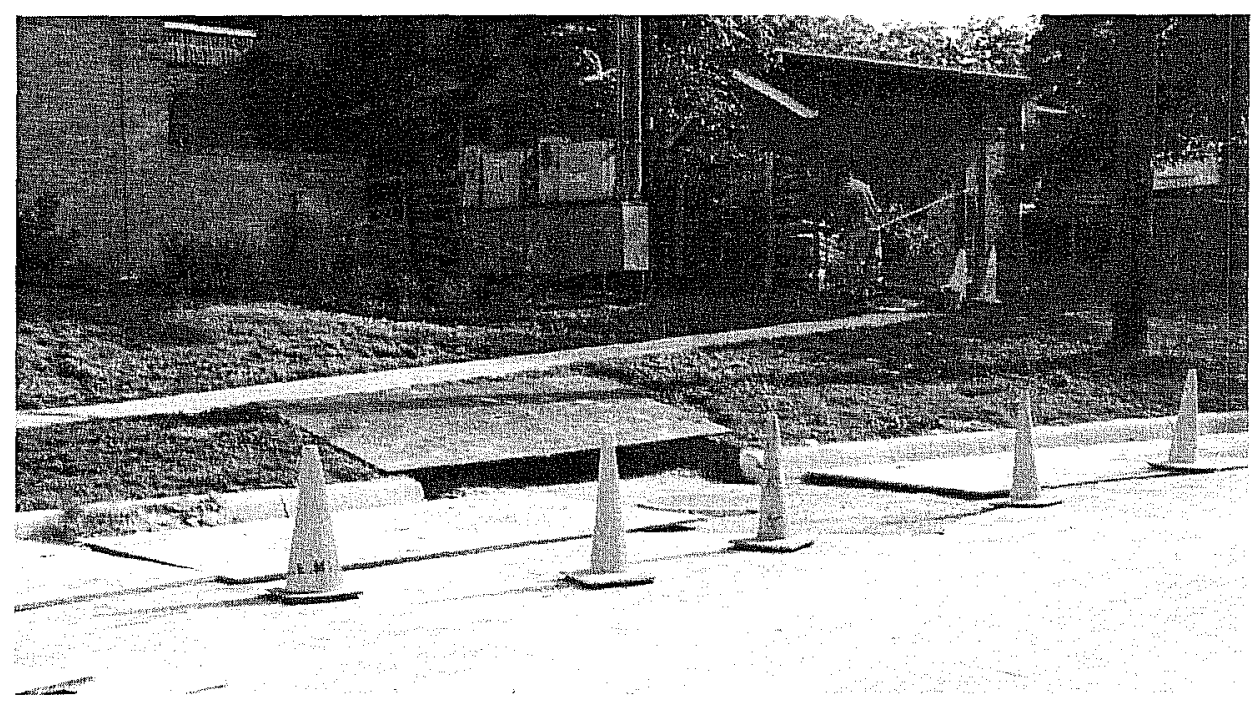

Figure A3-2. Facing northeast, location of the trench east of the manhole.

The completed manhole is in the foreground, and the back wall of the Visitors' Center is on the left. The partially re-filled trench is seen behind the telephone pole near the right edge of the photograph. CAR personnel can be seen in the background, at the site of the Colonial wall. 


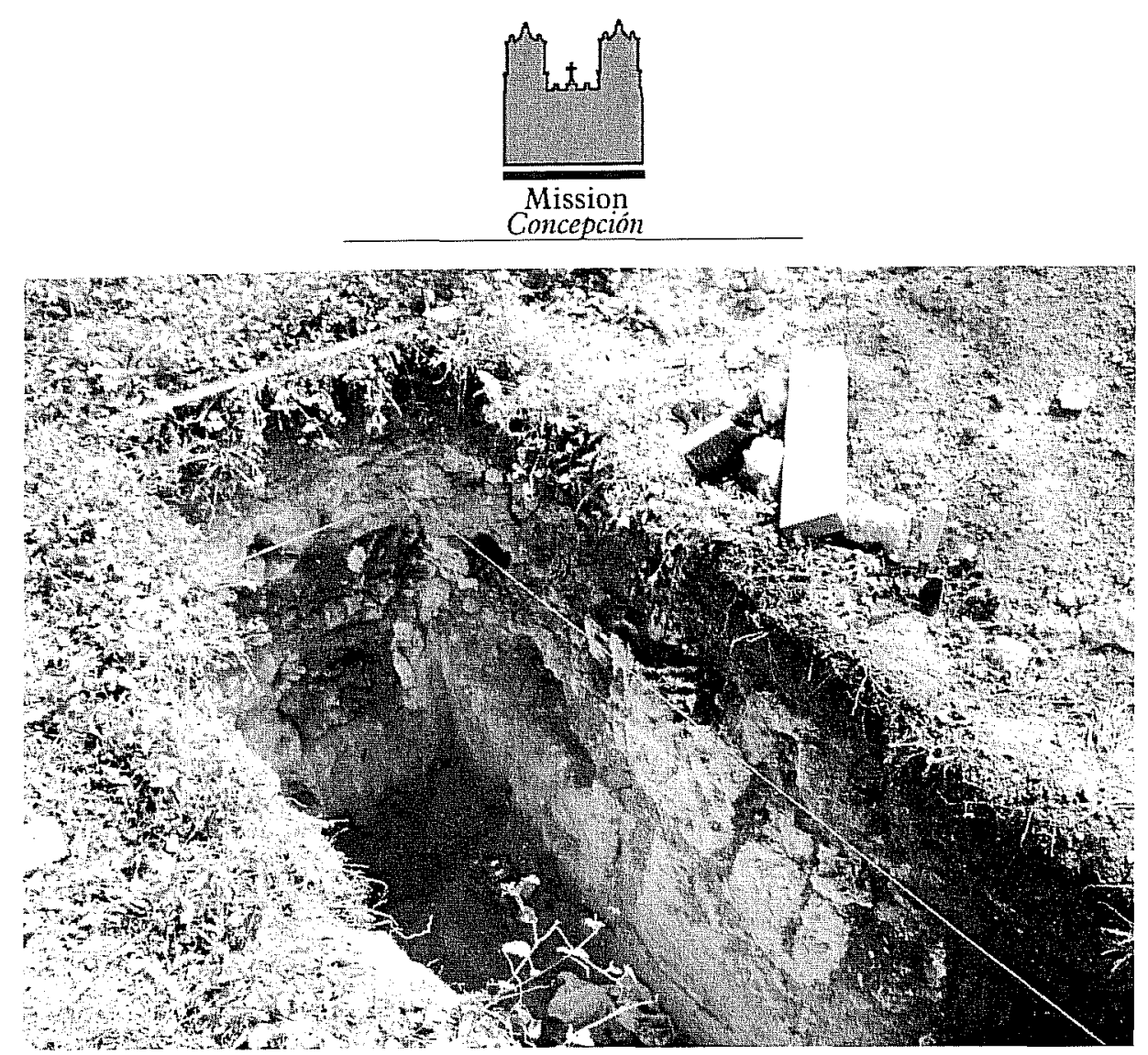

Figure A3-3. North end of trench showing remains of wall in the long (east) profile, and the possible palisade trench in the north profile.

\section{Wall Foundation}

The width of the north-south trench averaged approximately $65 \mathrm{~cm}$. The depth was approximately $130 \mathrm{~cm}$ in the north end becoming gradually shallower towards the south end, near the area of the sidewalk (Figure A3-1). The Colonial wall foundation ran in an eastwest direction and its average width was ca. $83 \mathrm{~cm}$ (Figure A3-3). This measurement is roughly equivalent to the Spanish vara used during the Colonial period (Haggard 1941:68-71). The maximum height of the foundation in the east wall profile is $58 \mathrm{~cm}$ and in the west wall profile it is $42 \mathrm{~cm}$. The foundation materials consisted of a soft limestone/caliche-like stone, in very roughly shaped blocks, apparently cemented together with remnants of a lime/sand mortar (Figure A3-4).

The north wall profile of the trench also revealed a layer of limestone cobbles and caliche/mortar that is either a floor or wall fall from the foundation itself (Figures A3-5 and A3-6). Underneath this layer is a fine sandy soil that could be a buried surface. Unfortunately, no artifacts were recovered in this layer. However, the north profile clearly indicates that the sediment layers north of the foundation are intact.

The trench cut revealed other features. Under the wall foundation in the eastern section of the trench is a posthole cut into the caliche bedrock. This may indicate that there was a jacal wall structure on the site before the stone foundation. The north wall profile revealed a trench about $25 \mathrm{~cm}$ wide, cut into the limestone/caliche bedrock. The bottom of this trench is at roughly the same level as the posthole feature in the east wall. The wide trench may have been dug for a palisade wall that ran perpendicular to the east-west wall. If this is the case, the juncture of these two walls was destroyed by the backhoe operations.

The profile of the east wall of the trench shows that there has been considerable disturbance south of the Colonial wall (Figure A3-4). A pit, filled with dark clay sediment, numerous artifacts, and some charcoal, 


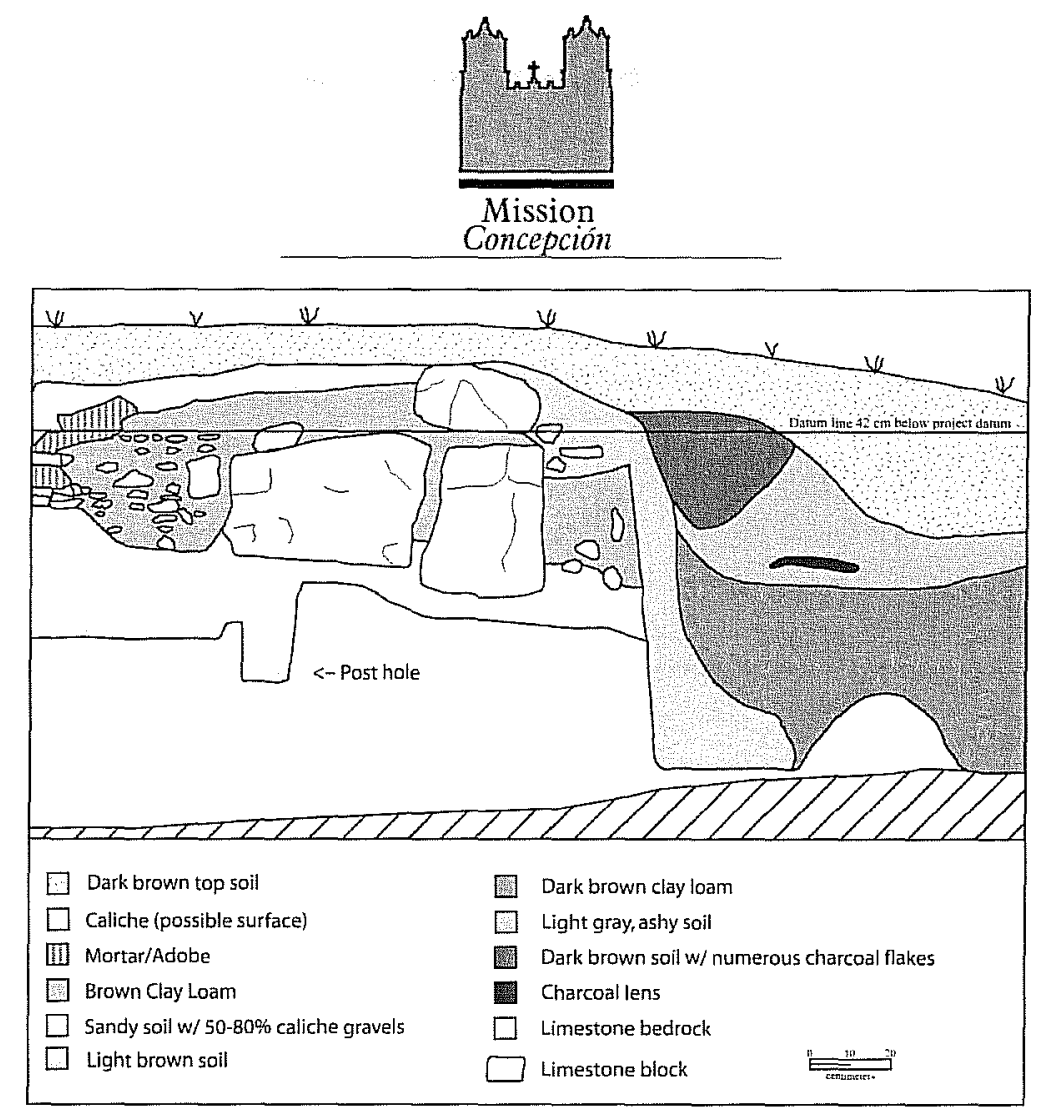

Figure A3-4. Profile of the east wall of the trench.

had been dug to a depth of about $105 \mathrm{~cm}$ below modern ground surface, just south of the wall. The artifacts indicate that this midden had been disturbed several times by other filling episodes. There is a distinct pit feature in the midden itself that contained a large amount of charcoal and rusted pieces of metal. The trash pit extends south to the sidewalk that borders Felisa Street.

The artifacts show a refuse deposit that is predominately of twentieth century origin with some intrusive artifacts from earlier dates. The artifacts ranged from wire nails, a modern liquor bottle with a plastic threaded cap, crown caps and a face powder compact. The intrusive artifacts were two Goliad ware sherds commonly associated with the Spanish Colonial missions of South Texas (Hard et al. 1995:41) and a Guanajuato Polychrome sherd that appeared in the early-nineteenth century from Mexico (Lister and Lister 1974:34-35).

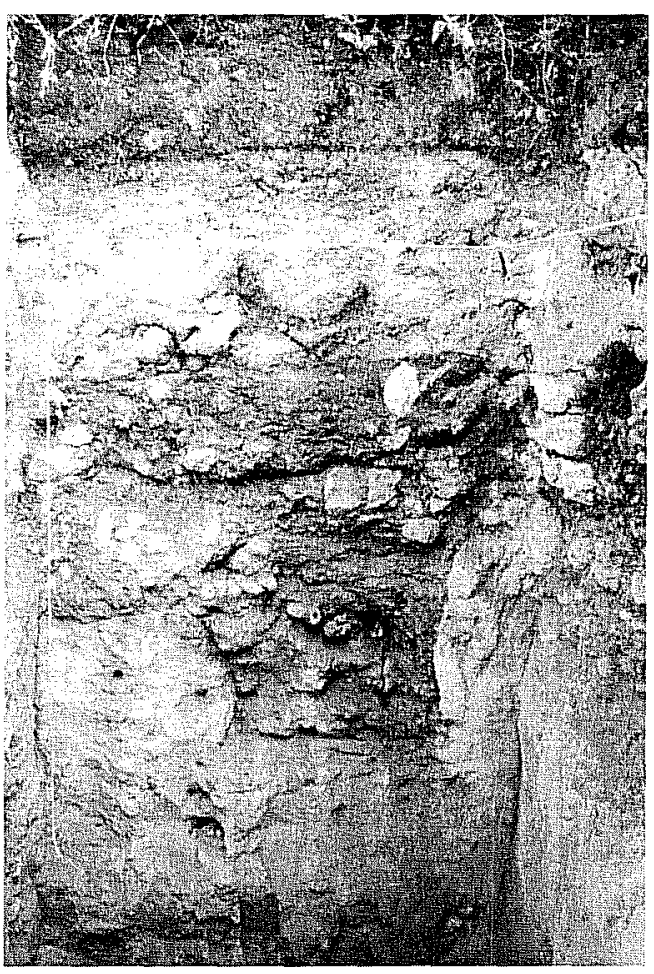

Figure A3-5. North wall of trench profile, showing possible palisade trench. 


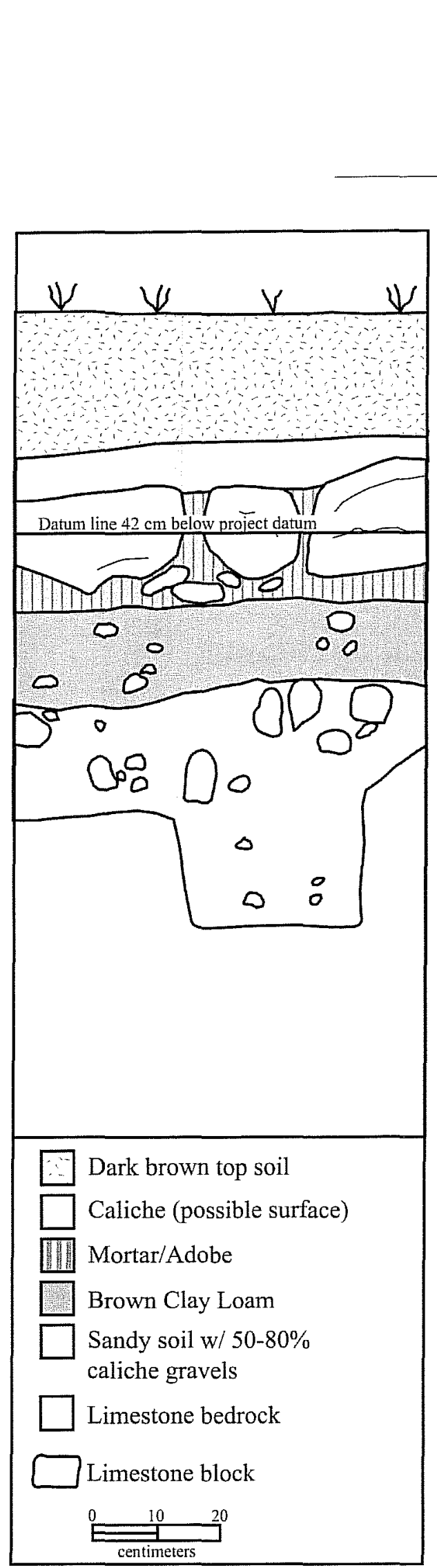

Figure A3-6. Profile of the north wall of the trench.

\section{Summary and Recommendation}

Based on the number of pipes encountered, particularly under Felisa Street, it is strongly indicated that there were many previous construction projects in this area. Therefore, any historic cultural deposits and features may have already been disturbed. The monitoring of the trenches excavated on Mission Road and Felisa Street revealed little or no damage to any historic deposits.

Unfortunately, there are no reliable historic maps of Mission Concepción that might explain the presence of this wall. As a result of their investigations including the careful examination of old deed records, Ivey and Fox (1999:52) noted: "It should be emphasized that although the south wall of the later pueblo built after 1756 had been located with a relatively high level of certainty, this wall line is not the southern limits of the site. The first convento complex extended at least $200 \mathrm{ft}$. further south down the [pre1990] line of Mission road, perhaps as far as the intersection of Felisa Street." It is unknown, however, if the wall uncovered during this investigation was, indeed, part of the old southern wall of the compound. The significance of the possible "floor" or possible wall fall north of the wall, with its underlying trench, is also unknown (see Figure A3-5).

The presence of the Colonial wall, as well as the acequia feature exposed during this project emphasizes that pockets of undisturbed Colonial deposits can and do survive in the general area of the mission despite previous construction phases. It is recommended that any future work within the general area of the mission should be monitored by an archaeologist. If future below-ground work is needed near the wall foundation, a program of extensive testing prior to the construction phase is highly recommended. Although much of the original Colonial deposits and features have been disturbed - the presence of small, minimally disturbed areas should serve to inspire caution. Such areas should be protected whenever possible and potential damage mitigated. 


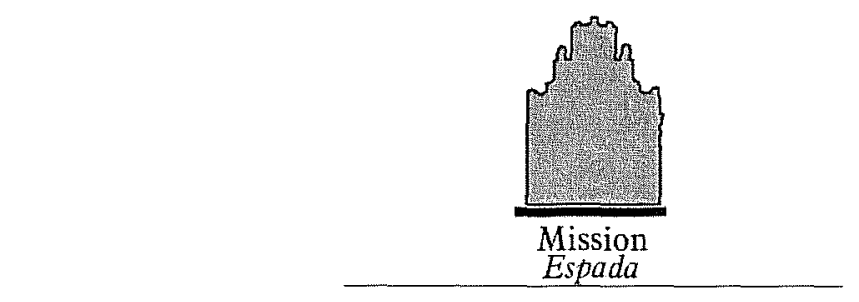

\section{Introduction}

In July of 1999, the Center for Archaeological Research (CAR), The University of Texas at San Antonio (UTSA) entered into a contract with City Public Service (CPS), an agency of the City of San Antonio, to provide testing and monitoring of electrical utility trenching activities at Mission San Francisco de la Espada (Figure 4-1). The electrical utility trench was designed to provide the mission with upgraded utilities support in connection with the first phase of the Mission Trails Underground Conversion Project. The installation was to be accomplished by sub-contractor, L. E. Meyers Company, Electrical Contractors of Houston, Texas. A representative of CAR met with the contractor on-site, July 9, 1999 to discuss the scope and route of the project. It was during these discussions that potential problems with the proposed route were considered, and upon the recommendation of the archaeologist from CAR, the route of the trench was moved further to the west to avoid possible impact on any archaeological resources located near the old compound wall.

Excavations began at the south end of the project area. The utility trench progressed toward the north, crossing the dry irrigation ditch, or acequia, to the rear of the mission Chapel and terminated at a manhole which was located in the middle of the intersection of Mission Road and the entrance to the Parishioners' parking lot.

Shovel testing began along the route of the trench at a point adjacent to the southwest corner of the mission compound and progressed to the center of the acequia on the north. Monitoring of the trench began at the same time and continued until the project was completed on July 17th, 1999.

\section{Historic Background}

One of the three missions relocated when the Presidio de los Tejas in East Texas was closed by Inspector
General Rivera in 1729, San Francisco de los Neches was moved to the San Antonio River valley. Renamed Mission San Francisco de la Espada, it was established March 5, 1731 as the southern-most of the five missions located in the area (Habig 1968a:202) (Figure 4-1). Shortly after the relocation, temporary quarters were constructed and the acequia, or irrigation ditch, was begun. By 1745, the acequia -with an aqueduct across Piedra Creek, a Friary, and Sacristy had been completed. In 1756, a small Chapel was constructed which by 1777 was in such a state of disrepair it was torn down (Tyler 1996:845).

On February 29, 1824, the mission was secularized and its Church and furnishings turned over to the pastor of San Fernando. The mission continued to deteriorate and suffered a fire on the mission compound in 1826. In September of 1831, orders were received to sell all mission property except the Church at public auction. And finally by 1840 , Father John Odin found the mission to be only a mass of ruins (Habig 1968a:224-225).

The existence of the Church can be mostly credited to Father Francis Bouchu, who was assigned to San Fernando as an assistant priest in 1855 . He took a special interest in the ruined mission and began working there in 1858 . He found only the façade and the rear wall of the Chapel standing.

$$
\begin{aligned}
& \text { "He has built with his own hands } \\
& \text { upon the ruins of the old convent and arcade } \\
& \text { a comfortable Priest house. Under his rule the } \\
& \text { Mission Chapel has been almost } \\
& \text { entirely renewed, the front only retaining } \\
& \text { a portion of its ancient work" } \\
& \text { (Corner 1890:p. 22). }
\end{aligned}
$$

After the departure of Father Bouchu in 1907, the Church was closed for repairs and did not reopen until 1915. At this time, a school was opened in the compound grounds by the Sisters of the Incarnate Word and Blessed Sacrament, which continued until 1967 (Tyler 1996). 


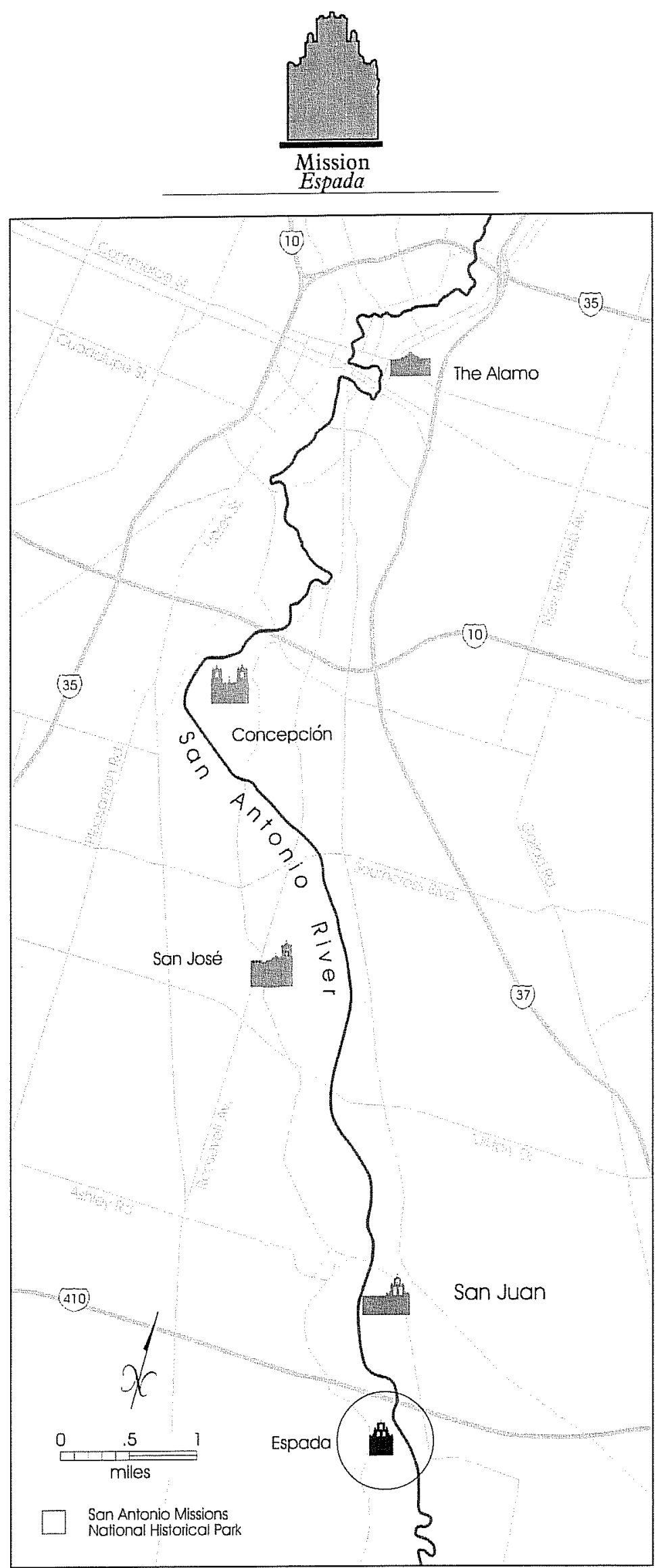

Figure 4-1. The five San Antonio Missions with Mission San Francisco de la Espada highlighted. 


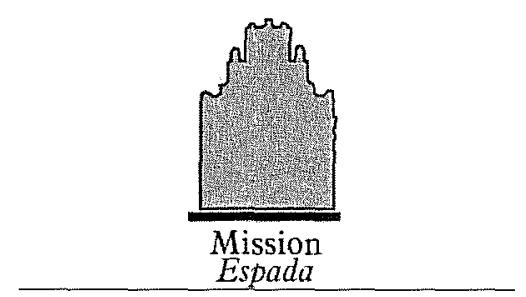

In 1983, the four lower missions in the San Antonio area were incorporated into San Antonio Missions National Historical Park (Figure 4-1), under the administration of the National Park Service (NPS), with the Church holdings remaining with the Catholic Church (Torres 1997:pp. xi-xiv).

\section{Previous Investigations}

In May of 1976, limited archaeological excavations were conducted on the exterior of the mission compound at the southeast corner of the wall adjacent to the bastion to facilitate both stabilization and repair (Fox and Hester 1976). In March of 1977, the Texas Historical Commission conducted excavations on two eighteenth century lime kilns immediately to the northeast of the mission compound (Killen and Scurlock 1978). In 1981, investigations were conducted in the vicinity of the church in an area identified as the possible location of the mission cemetery and an area along the east wall for a mid-twentieth century convent (Fox 1981). In 1984, the National Park Service conducted excavations on the interior of the rooms forming the southeast corner of the compound prior to stabilization and repairs (Escobedo 1985). In October of 1990, CAR initiated excavations in the southeast interior corner of the compound to determine structural foundations and the depth of deposits of the Mexican and Spanish period prior to necessary drainage modifications by the National Park Service (Meskill 1992). CAR also performed a series of shovel tests inside the compound in 1996 in advance of moderate surface modifications (Gross 1997).

\section{Testing and Monitoring}

On July 9, 1999, CAR archaeologist Cynthia Tennis met with representatives of CPS and the electrical installation crew of L. E. Meyers Company on-site to discuss the details of the project. It was noted that the planned route of the utility trench was likely to encounter Mission period deposits the nearer it approached the wall of the mission. This information was taken into consideration by Marco Garcia, CPS engineer, and the route was relocated further west to a point approximately 50 feet west of the Church and 40 feet west of the south end of the compound wall. Excavation of the trench began on the south end of the route with a Daewoo trackhoe fitted with a 24 " bucket and a Case Extendahoe 580L. At the south end, the trench was excavated to a depth of 7.5 feet to connect to a manhole in the street. The remainder of the trench, from the street edge to the northwest corner of the compound, was excavated to a depth of approximately 5.5 feet (Figure 4-2). Eleven shovel tests (STs) were completed in advance of the trenching and the data were returned to the laboratory (Figure 4-3). The analysis revealed that artifact density was extremely low and seemed to reflect a great deal of recent disturbance. Upon discussion with the principal investigator, it was decided to place two further shovel tests at the north end of the route near the acequia crossing to insure that the same pattern of disturbed deposits was present. These were completed on July 13, 1999 with no change in pattern and no significant artifacts recovered. (Table 4-1).

Monitoring of the trench was begun by archaeologist Waynne Cox of CAR on July 13, 1999. The excavation had now shifted to make the connection with the manhole on the north end of the route near the parking lot. As the crew was excavating under the water main to a fire hydrant, a 2" water line to the mission was severed and required repairs. The trench progressed across the dry portion of the acequia on a bearing of $330^{\circ}$ for approximately 13 meters. The only artifacts encountered within the acequia area were large displaced fragments of concrete and flagstone.

The following day, the trench which would cut across the dry acequia was completed. Some small pockets of rubble along with caliche and small gravels had been deposited within the channel. A small two-pound scale weight was recovered near the area of STs 12 and 13. 


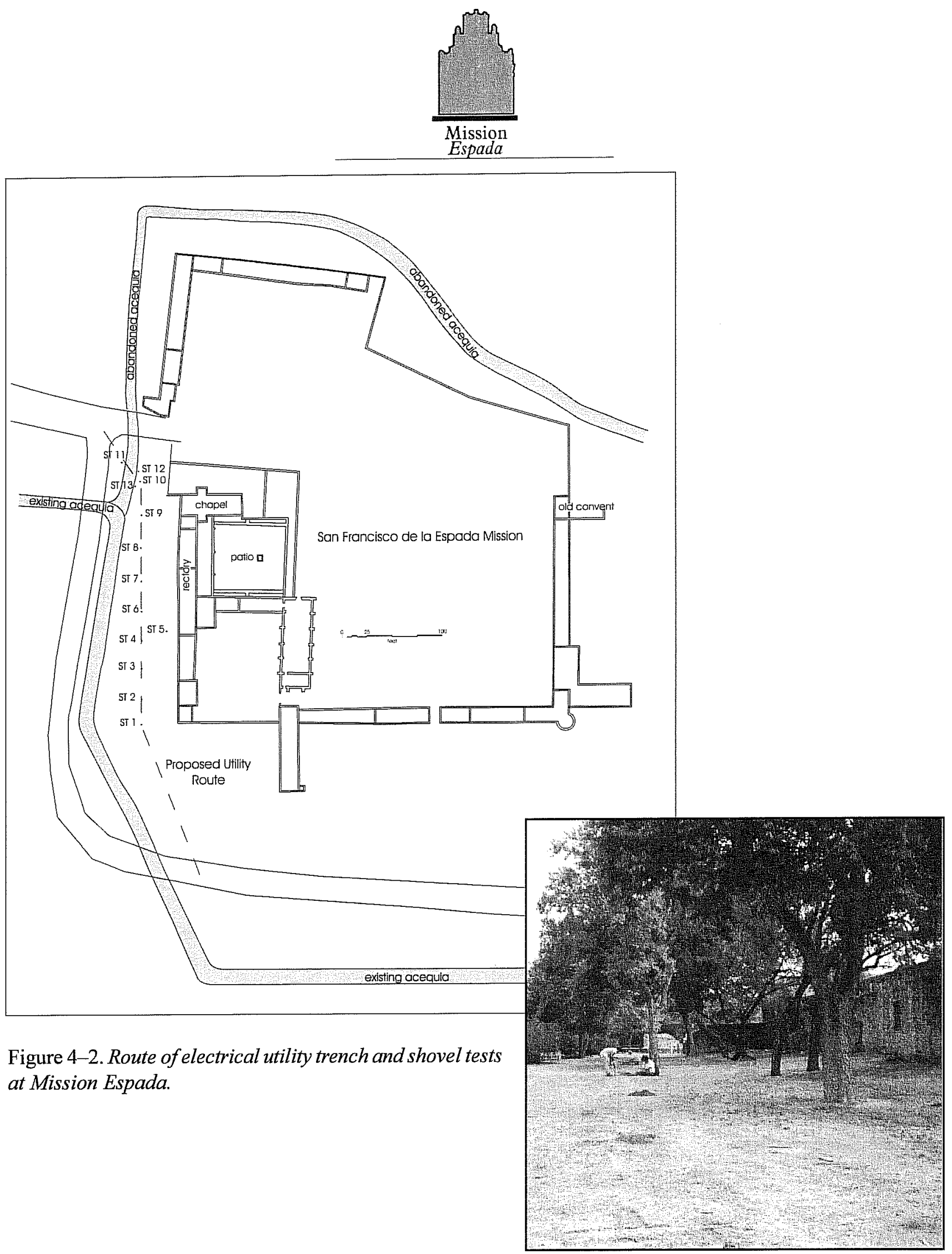

Figure 4-3. Section of Mission Espada's trenching area with advance shovel testing in progress. 


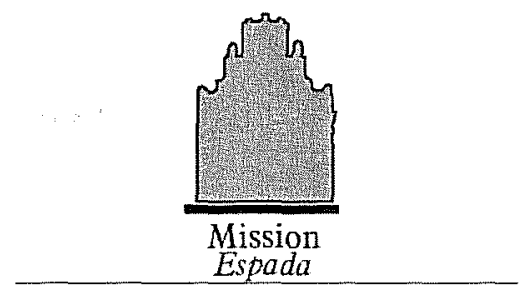

Table 4-1. Mission Espada shovel test results by level

\begin{tabular}{|c|c|c|c|c|c|c|}
\hline \multicolumn{7}{|c|}{ SHOVEL TEST RESULTS } \\
\hline St \# & & & & & & \\
\hline & LEVIIIII) & CoIOI & piexture & Structure & Inclusions & Hims combated \\
\hline \multirow[t]{4}{*}{1} & $0-6^{\prime \prime}$ & Dk brown & sandy & loose, dry & moderate & bone, glass, wood, snail \\
\hline & $6-12^{\prime \prime}$ & Dk brown & sandy & loose, dry & shell gravel, wood & bone, glass,ceramic \\
\hline & $12-18^{\prime \prime}$ & Dk brown & sandy & loose, dry & shell, wood & window glass, bone \\
\hline & $18-24^{\prime \prime}$ & Dk brown & sandy & loose, dry & shell, wood.cobbles & glass \\
\hline \multirow[t]{4}{*}{2} & $0-6^{n}$ & Gray & silty loam & small block & limestone pebbles & Goliad ware, bone \\
\hline & $6-12^{\prime \prime}$ & Gray & silty loam & small block & limestone pebbles & metal, glazed ceramic \\
\hline & $12-18^{\prime \prime}$ & Gray & silty loam & small block & limestone pebbles & bone, pottery \\
\hline & $18-24^{\prime \prime}$ & Gray & silty loam & fine & limestone pebbles & bone \\
\hline \multirow[t]{4}{*}{3} & $0-6^{\prime}$ & Dk brown & sandy & loose, dry & gravel.wood & bone,glass \\
\hline & $6-12^{\prime \prime}$ & Dk brown & sandy & loose,dry & cobbles, gravel, wood & glass, tin can \\
\hline & $12-18^{\prime \prime}$ & Dk brown & sandy & loose, dry & gravel.wood & none \\
\hline & $18-24^{\prime \prime}$ & Dk brown & sandy & loose, dry & root & none \\
\hline \multirow[t]{4}{*}{4} & $0-6^{\prime \prime}$ & Gray & Silty loam & granular,fine & limestone pebbles & glass, glazed ceramic, metal \\
\hline & $6-12^{1 *}$ & Gray & silty loam & granular,fine & limestone pebbles & glazed ceramic, glass, metal \\
\hline & $12-18^{\prime \prime}$ & Gray & silty loam & granular,fine & gravel & bone, pottery \\
\hline & $18-24^{4}$ & Gray & silty loam & granular,fine & limestone pebbles & bone \\
\hline \multirow[t]{4}{*}{5} & $0-6^{\prime \prime}$ & Dk brown & grandular & loose,sandy & rocks & metal, bone, glass \\
\hline & $6-12^{\prime \prime}$ & Dk brown & grandular & loose, sandy & rocks & metal, bone, whiteware \\
\hline & $12-18^{\prime \prime}$ & Dk brown & grandular & loose, sandy & & bone,ceramic \\
\hline & $18-24^{\prime}$ & Dk brown & grandular & blocky & & bone, decorated whiteware \\
\hline \multirow[t]{4}{*}{6} & $0-6^{\prime \prime}$ & Gray & silty loam & granular,fine & limestone pebbles & ceramic,glass \\
\hline & $6-12^{\prime \prime}$ & Gray & silty loam & Granular,fine & limestone pebbles & glass,ceramic, bone, nail \\
\hline & $12-18^{\prime \prime}$ & Gray & silty loam & granular,fine & limestone & glass, ceramic, bone, chert \\
\hline & $18-24^{\prime \prime}$ & Gray & silty loam & granular, fine & limestone & bone \\
\hline \multirow[t]{4}{*}{7} & $0-6^{11}$ & Dk brown & sandy & loose. Dry & & ceramics, bone, glass,metal \\
\hline & $6-12^{\prime \prime}$ & Dk brown & grandular & loose, diry & & majolica, glass, nail \\
\hline & $12-18^{\prime \prime}$ & Dk brown & grandular & loose, dry & & majolica, glass, bone \\
\hline & $18-24^{\prime \prime}$ & Dk brown & grandular & loose, dry & & bone \\
\hline \multirow[t]{4}{*}{8} & $0-6^{\prime \prime}$ & Gray & silty loam & blocky & limestone pebbles & majolica,bone,glass \\
\hline & $6-12^{\prime \prime}$ & Dk brown & silty loam & blocky & & glass \\
\hline & $12-18^{\prime \prime}$ & Gray & silty loam & blocky & & nail \\
\hline & $18-24^{\prime \prime}$ & Gray & silty loam & blocky & & bone \\
\hline \multirow[t]{3}{*}{9} & $0-6^{\prime \prime}$ & Dk brown & grandular & loose,dry & gravel, roots & glass, bone \\
\hline & $6-12^{\prime \prime}$ & Dk brown & grandular & loose, dry & & glass,ceramic, bone,bullet case \\
\hline & $12-18^{\prime \prime}$ & Dk brown & grandular & loose,dry & & glass, bone \\
\hline \multirow[t]{4}{*}{10} & $0-6^{\prime}$ & Gray & silty loam & blocky & pebbles & bottle, glass, nail \\
\hline & $6-12^{\prime \prime}$ & Gray & silty loam & blocky & pebbles & bone,glass,snail shell \\
\hline & $12-18 "$ & Gray & silty loam & blocky & pebbles & whiteware, bone, glass \\
\hline & $18-24^{\prime \prime}$ & Gray & silty loam & blocky & pebbles & bone,unglazed, majolica \\
\hline \multirow[t]{4}{*}{11} & $0-6^{\prime \prime}$ & Dk brown & grandular & loose & & Goliad, ceramic, bone, glass \\
\hline & $6-12^{11}$ & Dk brown & grandular & loose, dry & & ceramic, bone, glass, metal \\
\hline & $12-18^{\prime \prime}$ & Dk brown & grandular & loose, dry & & ceramic, bone, glass, metal \\
\hline & $18-24^{\prime \prime}$ & Dk brown & grandular & loose,dry & & \\
\hline \multirow[t]{4}{*}{12} & $0-6^{\prime \prime}$ & Gray brn & sandy clay & loose & rock, roots & bone, metal, goliad \\
\hline & $6-12^{\prime \prime}$ & Gray brn & sandy clay & loose & rock, roots & bone, glass, metal \\
\hline & $12-18^{\prime \prime}$ & Gray brn & sandy clay & sandy & rock, roots & bone, glass, metal \\
\hline & 18-24" & Gray brn & sandy clay & sandy & rock & ceramic, majolica, bone, glass \\
\hline \multirow[t]{4}{*}{13} & $0-6^{\prime \prime}$ & Lt brn,gray & silty loam & blocky & limestone pebbles & metal, brick, glass, bone \\
\hline & $6-12^{\prime \prime}$ & Brn, gray & silty loam & blocky & limestone, roots & brick, bone, glass \\
\hline & $12-18^{11}$ & Brn, gray & silty loam & blocky & limestone,sandstone & nail, bone, ceramic \\
\hline & $18 \cdot 24^{\prime \prime}$ & Brn, gray & silty loam & blocky & limestone & majolica, bone \\
\hline
\end{tabular}




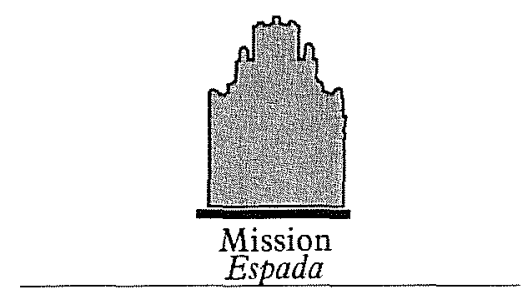

After crossing the acequia the trench was turned to a bearing of $170^{\circ}$ and began to progress toward the position of the new manhole installation near the northwest corner. No significant deposits were exposed along the western edge behind the Church or Rectory.

Excavation for the installation of the manhole revealed that the entire area to the west of the present Rectory was an old septic field. Six-inch galvanized concrete sewer pipes had been installed in trenches to feed a gravel-filled pit approximately two feet below the present surface. The concrete manhole fitting was installed that afternoon and electrical connections undertaken to connect the area to the Rectory's electrical service. As the trench progressed north from the manhole installation, the crew continued to encounter portions of the septic field including a large gravel-filled pit that was surmised to be the main sump. Monitoring continued as the connecting trenches were dug to tie all connections to the location of the manhole. Excavation was completed on July 17, 1999 with no significant deposits exposed.

\section{Summary and Recommendation}

Shovel testing and monitoring revealed that the area southwest of the compound of Mission Espada, extending to the west of the present Rectory, has been extremely disturbed. The probable cause of this disturbance was the placement of a septic field, and the installation and construction of that same facility. The area to the west of the Church revealed no significant deposits of a historical interest. Monitoring of the dry channel of the acequia indicated that considerable modern deposition and disturbance had occurred within the channel and no early deposits remained. No further work is recommended within this area; however, should future construction be considered in the area between the electrical trench and the Church at Mission Espada - monitoring should be considered. 


\section{References Cited}

Almazán, J. A. P. de

1731 Autos de Possession de las Misiones... March 5, 1731. Missions in Texas, Vol. 50, pp.19rev.-23rev. Spanish Archives. Texas General Land Office, Austin.

Atterbury, P. J., editor

1979 European Pottery and Porcelain. Mayflower Books, New York

Balkwill, D. M., and S. L. Cumbaa

1992 A Guide to the Identification of Postcranial Bones of Bos taurus and Bison bison. Canadian Museum of Nature, Ottawa.

Barkley, F. A.

1934 The statistical theory of pollen analysis. Ecology 47:439-447.

Barnes, M. P.

1980 Mexican Lead Glazed Earthenwares. In Spanish Colonial Frontier Research, compiled and edited by Henry F. Dobyns. Center for Anthropological Studies, Spanish Borderlands Research 1, Albuquerque.

Binford, L. R.

1978: Nunamiut Ethnoarchaeology. Academic Press, New York.

1981 Bones: Ancient Men and Modern Myths. Academic Press, New York.

Boessneck, J.

1970 Osteological Differences Between Sheep (Ovis aries Linné) and Goats (Capra hircus Linné). In Science in Archaeology, edited by D. Brothwell and E. Higgs, pp. 331-358. Praeger, New York.

Bradford, J., and D. Traylor

1981 Archaeological Excavations at the Mission San José Arbor, San Antonio, Texas: Site Designation 41BX3. Manuscript on file. National Park Service.

Brink, J. W.

1997 Fat Content in Leg Bones of Bison bison, and Applications to Archaeology. Journal of Archaeological Science 24:259-274.

Brown, D. A.

1984 Prospects and Limits of a Phytolith Key for Grasses in the Central United States. Journal of Archaeological Science 11:345-368.

Brown, M. J., A. A. Fox, and B. A. Meissner

1994 Archaeological Testing for the Mission Road Realignment Project, Phase II, at Mission Concepción, San Antonio, Texas. Archaeological Survey Report No. 222. Center for Archaeological Research, The University of Texas at San Antonio. 
Cargill, D. A.

1996 Stable Isotope Analysis at Mission San Juan Capistrano, San Antonio Texas. Unpublished Master's thesis, The University of Texas at San Antonio.

1999 Assessing Native American Permanency Versus Mobility at Mission San Juan Capistrano Through the Use of Stable Isotope Analysis. Paper presented at the 32nd Conference on Historical and Underwater Archaeology, Salt Lake City, Utah.

Cargill, D. A., and R. C. Robinson

2000 Archaeological Testing and Monitoring of a Service Drive at Mission San Juan Capistrano, San Antonio, Texas. Archaeological Survey Report, No. 296. Center for Archaeological Research, The University of Texas at San Antonio.

Charlton, T. H., and R. R. Katz

1979 Tonalá Bruñida Ware, Past and Present. Archaeology 32(1): 45-53.

Clark, J. W., Jr.

1978 Mission San José y San Miguel de Aguayo: Archeological Investigations, December 1974. Archeological Report No. 29. Texas Historical Commission, Austin.

Clark, J. W., Jr., and E. J. Prewitt

1979 Archeological Test Excavations in Areas to be Affected by a Proposed French Drain West of the Granary, Mission San José State Historic Site (41BX3), Bexar County, Texas. Reports of Investigations 3. Prewitt and Associates, Austin.

Corner, W. (compiler and editor)

1890 San Antonio de Béxar: A Guide and History. Bainbridge and Corner, San Antonio, Texas

Davis, E. M., K. Gilmore, L. Harper, R. K. Harris, E. B. Jelks, and B. Yancy

1967 The Site. The Gilbert Site: A Norteño Focus Site in Northeastern Texas. Bulletin of the Texas Archeological Society, 37:1-17.

Deagan, $\mathrm{K}$.

1987 Artifacts of the Spanish Colonies of Florida and the Caribbean 1500-1800, Vol. I: Ceramics, Glassware, and Beads. Smithsonian Institution Press, Washington, D.C.

deFrance, S. D.

1999 Zooarcheological Evidence of Colonial Culture Change: A Comparison of Two Locations of Mission Espiritu Santo de Zuñiga and Mission Nuestra Señora del Rosario, Texas. Bulletin of the Texas Archeological Society 70:169-188.

Escobedo, J. T.

1985 The Post Colonial House: An Excavation Report. Manuscript on file at The Center for Archaeological Research, The University of Texas at San Antonio.

Escobedo, S.

1985 Untitled report on 1984 excavations at Mission Espada. Copy on file at the Center for Archaeological Research, The University of Texas at San Antonio. 
Fox, A. A.

1974 Lead Glazed Wares. In Mission Rosario Archeological Investigations 1973. Texas Parks and Wildlife Department, Historic Sites and Restoration Branch, Archeological Report 14, Part 1:55-60.

1981 Test Excavations at Mission San Francisco de la Espada. Archaeological Survey Report 108. Center for Archaeological Research, The University of Texas at San Antonio.

1987 Archaeological Investigation of a Well at Mission San José y San Miguel de Aguayo, San Antonio, Texas. Manuscript on file at the Center for Archaeological Research, The University of Texas at San Antonio.

1988 Archaeological Excavations at Mission Concepción, Fall of 1986. Archaeological Survey Report No. 172, Center for Archaeological Research, The University of Texas at San Antonio.

1989 Monitoring of Utility Trenches at Mission Concepción, San Antonio, Texas, 1988. Archaeological Survey Report No. 180, Center for Archaeological Research, The University of Texas at San Antonio.

1992 Archaeological Investigation to Locate the Northwest Corner of Mission Concepción, San Antonio, Bexar County, Texas. Archaeological Survey Report No. 212, Center for Archaeological Research, The University of Texas at San Antonio.

1993 Archaeological Testing and Monitoring in Connection with a Drainage Project at Mission San Juan Capistrano, San Antonio, Bexar County, Texas. Archaeological Survey Report, No. 217. Center for Archaeological Research, The University of Texas at San Antonio.

1999 Monitoring of Core Drilling and Testing at Mission San Juan Capistrano and San Francisco de la Espada, San Antonio, Bexar County, Texas. Ford, Powell, Carson, Inc. and The Archdiocese of San Antonio.

Fox, A. A., and I. W. Cox

1991 Testing of the San José Mission Acequia, San Antonio Missions National Historical Park, Bexar County, Texas. Archaeological Survey Report, No. 207. Center for Archaeological Research, The University of Texas at San Antonio.

Fox, A. A., and T. R. Hester

1976 Archaeological Test Excavations at Mission San Francisco de la Espada. Archaeological Survey Report 22. Center for Archaeological Research, The University of Texas at San Antonio.

Fox, A. A., F. A. Bass, Jr., and T. R. Hester

1976 The Archaeology and History of Alamo Plaza. Center for Archaeological Research, The University of Texas at San Antonio, Archaeological Survey Report 16.

Fox, A. A., D. W. Day, and L. Highley

1980 Archaeological and Historical Investigations at Wallisville Lake, Chambers and Liberty Counties, Texas. Center for Archaeological Research, The University of Texas at San Antonio, Archaeological Survey Report 90.

Fox, D. E.

1970 Archeological Salvage at Mission San José, December 1969, April and August 1970. Texas Historical Survey Committee, Austin.

1979 The Lithic Artifacts of Indians at the Spanish Colonial Missions, San Antonio, Texas. Special Report 8. Center for Archaeological Research, The University of Texas at San Antonio. 
Francis, J. R.

1999 Non-Indian Burials at the Spanish Colonial Missions: San Juan Capistrano, San Antonio, Texas. Paper presented at the Society for Historical Archaeology 32nd Conference on Historical and Underwater Archaeology, Salt Lake City, Utah.

Fredlund, G., and L. Tieszen

1994 Modern Phytolith Assemblages from the North American Great Plains. Journal of Biogeography 21:321-335.

Frink, D. S.

1992 The Chemical Variability of Carbonized Organic Matter Through Time. Archaeology of Eastern North America 20:67-79.

1994 The Oxidizable Carbon Ratio (OCR): A proposed Solution to Some of the Problems Encountered with Radiocarbon Data. North American Archaeologist 15(1):17-29.

George, E.

1975 Historic Architecture of Texas, The Falcón Reservoir: Texas Historical Foundation, Austin.

Gerald, R. E.

1968 Spanish Presidios of the Late Eighteenth Century in Northern New Spain. Museum of New Mexico Research Records No. 7, Museum of New Mexico Press, Santa Fe.

Gilbert, B. M.

1990 Mammalian Osteology. Missouri Archaeological Society, Columbia, Missouri.

Godden, G. A.

1975 British Pottery, An Illustrated Guide. Clarkson N. Potter, Inc., New York.

Goggin, J. M.

1964 The Spanish Olive Jar. In Indian and Spanish Selected Writings. University of Miami Press, Coral Gables.

1968 Spanish Majolica in the New World. Yale University Publications in Anthropology 72. Yale University.

Greer, G. H., and H. Black

1971 The Meyer Family: Master Potters of Texas. Trinity University Press, San Antonio.

Gross, K. J.

1997 Archaeological Testing of the New Plaza at Mission San Francisco de la Espada (41BX4), San Antonio, Texas. Archaeological Survey Report 262. Center for Archaeological Research, The University of Texas at San Antonio.

1998 Archaeological Testing and Monitoring for a Proposed Drainage Channel at Mission San Juan Capistrano, San Antonio, Texas. Archaeological Survey Report, No. 283. Center for Archaeological Research, The University of Texas at San Antonio. 
Habig, M. A.

1968a The Alamo Chain of Missions: A History of San Antonio's Five Old Missions. Franciscan Herald Press. Chicago.

1968b San Antonio's Mission San José, State and National Historic Site, 1720-1968. The Naylor Company, San Antonio, Texas.

Hafernik, D., and A. A. Fox

1984 Archaeological Testing of Proposed Sewer Line Locations at Mission San José. Archaeological Survey Report, No. 138. Center for Archaeological Research, The University of Texas at San Antonio.

Haggard, V.

1941 Handbook for Translators of Spanish Historical Documents. Archives Collections, The University of Texas at Austin.

Hard, R. J., A. A. Fox, I. W. Cox, K. J. Gross, B. A. Meissner, G. I. Mendez, C. L. Tennis, and J. E. Zapata 1995 Excavations at Mission San José y San Miguel de Aguayo, San Antonio, Texas. Archaeological Survey Report, No. 218. Center for Archaeological Research, The University of Texas at San Antonio.

Harris, R. K., and I. M. Harris

1967 Trade Beads, Projectile Points, and Knives. In A Pilot Study of Wichita Indian Archaeology and Ethnohistory, assembled by R. E. Ball, E. B. Jelks, and W. W. Newcomb, pp.129-162. Report to the National Science Foundation, Southern Methodist University.

Harris, R. K., I. M. Harris, J. C. Blaine, and J. Blaine

1965 A Preliminary Archeological and Documentary Study of the Womack Site, Lamar County, Texas. Bulletin of the Texas Archeological Society 36:287-363.

Henderson, J., and J. W. Clark, Jr.

1984 Test Excavations at the Acequia and Other Features at Mission San José, Bexar County, Texas. Publications in Archeology Report 25. State Department of Highways and Public Transportation, Highway Design Division, Austin.

Hester, T. R.

1998 The Role of Stone Tools among the Mission Indians of Northeastern Mexico and Texas. In Transformations on the Mission Frontier: Texas and Northeastern Mexico, edited by G. Keyes, pp. 91-106. Our Lady of the Lake University, San Antonio.

1989 Perspectives on the Material Culture of the Mission Indians of the Texas - Northeastern Borderlands. In Columbian Consequences, Vol. 1, edited by D. H. Thomas, pp. 213-229. Smithsonian Institution, Washington.

1977 The Lithic Technology of Mission Indians in Texas and Northeastern Mexico. Lithic Technology 6(1-2):9-13.

Hildebrand, $M$.

1955 Skeletal Differences Between Deer, Sheep, and Goats. California Fish and Game 41:327-346.

Hillson, S.

1986 Teeth. Cambridge University Press, Cambridge. 
Hunziker, J. M.

1998 Faunal Analysis. In Investigations of the Southeast Gateway at Mission San José, Bexar County, Texas, by C. L. Tennis, pp.22-26. Archaeological Survey Report No. 252, Center for Archaeological Research, The University of Texas at San Antonio.

Ivey, J. E.

1982 Draft Report on Archaeological Testing at the San Antonio Missions. Draft on file at the Center for Archaeological Research, The University of Texas at San Antonio.

Ivey, J. E., and A. A. Fox

1999 Archaeological Investigations at Mission Concepción and Mission Parkway. Archaeological Survey Report 114. Center for Archaeological Research, The University of Texas at San Antonio.

Ivey, J. E., M. B. Thurber, and S. Escobedo

1990 Of Various Magnificence. The Architectural History of the San Antonio Missions in the Colonial Period and the Nineteenth Century. Volume One. National Park Service Professional Papers No. 11, Santa Fe. Draft on file at the Center for Archaeological Research, The University of Texas at San Antonio.

Jones, J. G., and V. M. Bryant, Jr.

1992 Phytolith Taxonomy in Selected Species of Texas Cacti. Phytolith Systematics: Emerging Issues, editor, George Rapps, Jr., and Susan Mulholland. Plenum Press, New York.

Jelks, E. B. (editor)

1967 The Gilbert Site: A Norteño Focus Site in Northeastern Texas. Bulletin of the Texas Archeological Society, Vol. 37:100-104.

Kaplan, L., M. B. Smith, and L. A. Sneddon

1992 Cereal Grain Phytoliths of Southwest Asia and Europe. In Phytolith Systematics: Emerging Issues, edited by G. Rapp, Jr., and S. Mulholland, pp. 149-174. Plenum, New York.

Kendrick, G.

1966 The Antique Bottle Collector. Edwards Brothers, Ann Arbor, Michigan.

1967 Bottle Fragments Betray Age of Historical Sites. El Palacio 74(2):19-24.

Killen, K., and D. Scurlock

1978 A Report on Preliminary Test Excavations at Mission Espada Kilns, San Antonio, Texas. Preliminary Draft. Manuscript on file, Texas Historical Commission, Austin, Texas.

Labadie, J. H.

1989 Archaeological and Historical Investigations for the Mission Road Realignment Project, San Antonio, Texas. Archaeological Survey Report No. 173. Center for Archaeological Research, The University of Texas at San Antonio.

Lister, F. C., and R. H. Lister

1974 Maiolica in Colonial Spanish America. Historical Archaeology 8:17-52.

Logan, H. C.

1959 Cartridges - A Pictorial Digest of Small Arms Ammunition. Bonanza Books, New York. 
Lyman, R. L.

1994 Vertebrate Taphonomy. Cambridge University Press, Cambridge.

McAllister, L. S., and J. L. Michel

1993 Collecting Yellow Ware, An Identification and Value Guide. Schroeder Publishing Company, Paducah, Kentucky.

Meissner, B. A.

1997 Making the Man: Clothing Remains from the Alamodome Project. In Archaeology at the Alamodome: Investigations of a San Antonio Neighborhood in Transition, edited by A. A. Fox, M. Renner, and R. J. Hard. Vol. III, Artifact and Special Studies. Center for Archaeological Research, The University of Texas at San Antonio, Archaeological Survey Report 238:119-164.

1998a Vertebrate Faunal Remains. In Mission San José Indian Quarters Foundation Project, Bexar County, Texas: With Appendixes on the Monitoring of the San José Bus Drive and Granary Parking Lot, and on the Monitoring and Shovel Testing of the San José Service Drive, by S. A. Tomka and A. A. Fox. Archaeological Survey Report, No. 278. Center for Archaeological Research, The University of Texas at San Antonio.

1998b Analysis of Vertebrate Faunal Remains from a Spanish Colonial Mission, San Antonio de Valero (the Alamo), Bexar County, Texas. Unpublished Master's thesis on file at the Center for Archaeological Research, The University of Texas at San Antonio.

1999a Vertebrate Faunal Remains. In Archaeological Investigation of Rainwater Catchment Basins Along the South Wall of Mission San José, San Antonio, Texas, by S. A. Tomka and A. A. Fox, pp. 39-46. Archaeological Survey Report No. 287, Center for Archaeological Research, The University of Texas at San Antonio.

1999b Vertebrate Faunal Remains. In Mission San José, Repointing and Underpinning Project, San Antonio, Texas, by S. A. Tomka and A. A. Fox. Archaeological Survey Report, No. 294. Center for Archaeological Research, The University of Texas at San Antonio.

1999c Analysis of Vertebrate Faunal Remains from a Spanish Colonial Deposit at Mission San Antonio de Valero (the Alamo). Bulletin of the Texas Archeological Society 70:281-313.

Meskill, F. K.

1992 Archaeological Testing Within the Southeast Corner of the Plaza at Mission Espada, San Antonio, Bexar County, Texas. Archaeological Survey Report 208. Center for Archaeological Research, The University of Texas at San Antonio.

Miller, G.

1980 Classification and Economic Scaling of 19th Century Ceramics. Historical Archaeology 14:1-19.

Munsey, C.

1970 The Illustrated Guide to Collecting Bottles. Hawthorn Books, Inc., New York.

Nicholson, R. A.

1996 Bone Degradation, Burial Medium and Species Representation: Debunking the Myths, an ExperimentBased Approach. Journal of Archaeological Science 23:513-533.

Nickels, D. L.

20001999 Excavations at Mission Rosario. Archaeological Survey Report, No. 298. Center for Archaeological Research, The University of Texas at San Antonio. 
Nickels, D. L., and A. A. Fox

1999 Archaeological Investigations Within the Church Sacristy at Mission San José (41BX3), San Antonio, Bexar County, Texas. Archaeological Survey Report, No. 242. Center for Archaeological Research, The University of Texas at San Antonio.

Olsen, Stanley J.

1960 Post-Cranial Skeletal Characters of Bison and Bos. Peabody Museum, Cambridge, MA.

1964 Mammal Remains from Archaeological Sites Part I; Southeastern and Southwestern United States. Peabody Museum, Cambridge.

1968 Fish, Amphibian, and Reptile Remains from Archaeological Sites Part I: Southeastern and Southwestern United States. Peabody Museum, Cambridge.

Piperno, D. R.

1988 Phytolith Analysis. Academic Press, New York.

Reitz, E. J., and C. M. Scarry

1985 Reconstructing Historic Subsistence with an Example from Sixteenth-Century Spanish Florida. Special Publications No. 3, Society for Historical Archaeology, Ann Arbor, MI.

Rhodes v. Whitehead, et al.

1903 Rhodes v. Whitehead, et al. In Report of Cases Argued and Decided in the Supreme Court of the State of Texas during the latter part of Tyler Session 1863, Austin 1863, Galveston, Tyler and Austin 1864, and Galveston Session 1865. Volume XXVII. West Publishing Company, St. Paul, Minnesota

Roberson, W., and T. W. Medlin

1976 Expedient Core Technology and Sedentism. In The Organization of Core Technology, edited by J. K. Johnson and C. A. Morrow, pp.285-304. Special Studies in Archaeological Research, Westview, Boulder, Colorado.

Robinson, R. L.

1982 Biosilica Analysis of Three Prehistoric Sites in Choke Canyon Reservoir, Live Oak County, Texas: Preliminary Summary of Climatic Implications. In Archaeological Investigations at Choke Canyon Reservoir, South Texas: The Phase I Findings, by G. D. Hall, S. L. Black, and C. Graves, pp. 597-610. Choke Canyon Series 5. Center for Archaeological Research, The University of Texas at San Antonio.

Rosen, A. M.

1992 Preliminary Identification of Silica Skeletons from Near Eastern Archaeological Sites: An Anatomical Approach. In Phytolith Systematics: Emerging Issues, edited by G. Rapp, Jr., and S. Mulholland, pp. 129-147. Plenum Press, New York.

Rovner, I.

1983 Plant Opal Phytolith Analysis: Major Advances in Archaeobotanical Research. Advances in Archaeological Method and Theory 6:225-266. Academic Press, New York.

Santucci, K. C.

1981 The Use Of Handwrought And Cut Nails As Chonological [sic] and Cutlural [sic] Indicators. Occasional Publication, No. 6, Popular Archaeology, Arlington, Virginia. 
Schmid, E.

1972 Atlas of Animal Bones for Prehistorians, Archaeologists, and Quaternary Geologists (Knochenatlas Für Prähistoriker, Archäologen und Quartärgeologen). Elsevier Publishing, Amsterdam.

Schiffer, M. B.

1987 Formation Processes of the Archaeological Record. University of New Mexico Press, Albuquerque.

Schuetz, M. K.

1968 The History and Archeology of Mission San Juan Capistrano, San Antonio, Texas. Volume 1. Report No. 10. State Building Commission, Archeological Program, Austin.

1969 The History and Archeology of Mission San Juan Capistrano, San Antonio, Texas. Volume II. Report No. 11. State Building Commission, Archeological Program, Austin.

1970 Excavation of a Section of the Acequia Madre in Bexar County, Texas, and Archeological Investigations at Mission San José in April 1968. Archeological Report 19. Texas Historical Survey Committee, Austin.

1974 The Dating of the Chapel at Mission San Juan Capistrano, San Antonio, Texas. Texas Historical Commission, Office of the State Archeologist, Special Reports, No. 12. Austin.

1980 The History and Archeology of Mission San Juan Capistrano, San Antonio, Texas. Volume IV. Excavation of the Convento. Manuscript on file, Office of the State Archeologist, Texas Historical Commission, Austin.

Scurlock, D.

1976 Archeological and Architectural Tests at Mission San Juan Capistrano Church. Texas Historical Commission, Office of the State Archeologist, Special Report No. 21. Austin.

Scurlock, D., and D. E. Fox

1977 An Archeological Investigation of Mission Concepción, San Antonio, Texas. Office of the State Archeologist, Texas Historical Commission, Austin.

Scurlock, D., A. Benavides, Jr., D. Isham, and J. W. Clark, Jr.

1976 An Archeological and Historical Survey of the Proposed Mission Parkway, San Antonio, Texas. Archeological Survey Report No. 17. Texas Historical Commission, Office of the State Archeologist, Austin.

Seifert, D. J.

1977 Archaeological Majolicas of the Rural Teotihuacan Valley, Mexico. Unpublished Ph.D. dissertation, The University of lowa.

Simmons, M., and F. Turley

1980 Southwestern Colonial Ironwork. Museum of New Mexico Press. Santa Fe.

Tennis, C. L.

1998 Investigations of the Southeast Gateway at Mission San José, Bexar County, Texas. Archaeological Survey Report, No. 252. Center for Archaeological Research, The University of Texas at San Antonio.

2001 Nuestra Señora del Refugio. Archaeological Survey Report, in press. Center for Archaeological Research, The University of Texas at San Antonio. 
Thurber, M. B., S. Escobedo, T. Ireland, and J. E. Ivey

1993 Of Various Magnificence, The Architectural History of the San Antonio Missions in the Colonial Period and the Nineteenth Century. Volume II. National Park Service Professional Papers No. 11. Santa Fe. Draft on file at the Center for Archaeological Research, The University of Texas at San Antonio.

Tomka, S. A.

1989 Differentiating Lithic Reduction Techniques: An Experimental Approach. In Experiments in Lithic Technology, edited by D. S. Amick and R. P. Mauldin, pp. 137-161. BAR International Series 528.

Tomka, S. A., and A. A. Fox

1998 Mission San José Indian Wall Base Project, Bexar County, Texas. Archaeological Survey Report, No. 278. Center for Archaeological Research, The University of Texas at San Antonio.

1999 Archaeological Investigations of Rainwater Catchment Basins Along the South Wall of Mission San José, San Antonio, Texas. Archaeological Survey Report, No. 287. Center for Archaeological Research, The University of Texas at San Antonio.

Tomka. S. A., A. A. Fox, and B. A. Meissner

1999 Mission San José, Repointing and Underpinning Project, San Antonio, Texas. Archaeological Survey Report, No. 294. Center for Archaeological Research, The University of Texas at San Antonio.

Tordoff, J. P.

1979 Some Observations on the Quantitative Relationship Between Stanley South's Artifact Patterns and "Primary De Facto" Refuse. In Historical Archaeology 13: 38-47.

Torres, L.

1997 Voices from the San Antonio Missions. Texas Tech University Press, Lubbock.

Turner, D. D.

1988 Excavations at San Juan Capistrano, 41 BX 5, Bexar County, Texas. Archaeological Survey Report, No. 171. Center for Archaeological Research, The University of Texas at San Antonio.

Turner, E. S., and T. R. Hester

1993 A Field Guide to Stone Artifacts of Texas Indians. Second Edition. Gulf Publishing, Houston.

Twiss, P. C.

1983 Dust Deposition and Opal Phytoliths in the Great Plains. Transactions of the Nebraska Academy of Sciences, XI:73-82.

1987 Grass-opal Phytoliths as Climatic Indicators of the Great Plains Pleistocene. In Quaternary Environments of Kansas, edited by W. C. Johnson, pp. 179-188. Kansas Geological Survey Guidebook Series 5.

Tyler, R. (editor)

1996 San Francisco de la Espada. In The New Handbook of Texas, Vol. 5, edited by R. Tyler, pp. 845-846. The Texas State Historical Association, Austin.

Valdéz, $\mathrm{J}$.

1968 [1720] "Report of Captain Juan Valdéz, March 13, 1720". In The San Josê Papers, Part I: 1719-1791, Fr. B. Leutenegger, translator, Fr. M. A. Habig, compiler and annotator. Old Spanish Missions Historical Research Library, San Antonio, Texas. 


\section{Vaughan, $\mathrm{M}$.}

1997 Kitchen Utensils and Tablewares. In Archaeology at the Alamodome: Investigations of a San Antonio Neighborhood in Transition, Vol. 3, edited by A. A. Fox, M. Renner, and R. J. Hard. pp. 209-229. Archaeological Survey Report 238. Center for Archaeological Research, The University of Texas at San Antonio.

Vehik, S. C.

1977 Bone Fragments and Bone Grease Manufacturing: A Review of Their Archaeological Use and Potential. Plains Anthropologist 22:169-182.

Von Endt, D. W., and D. J. Ortner

1984 Experimental Effects of Bone Size and Temperature on Bone Diagenesis. Journal of Archaeological Science 11:247-253.

Zapata, J. E.

1997 Alamodome and Abroad: A Composite Inquiry on Toy Marbles. In Archaeology at the Alamodome: Investigations of a San Antonio Neighborhood in Transition, Vol. 3, edited by A. A. Fox, M. Renner, and R. J. Hard, pp, 100-119. Archaeological Survey Report, No. 238. Center for Archaeological Research, The University of Texas at San Antonio. 


\section{,}

